UNIVERSIDADE FEDERAL DE MINAS GERAIS - UFMG

FACULDADE DE EDUCAÇÃO - FaE

PROGRAMA DE PÓS-GRADUAÇÃO EM EDUCAÇÃO

\title{
CAFÉS CIENTÍFICOS - INTERAÇÕES ENTRE A COMUNIDADE CIENTÍFICA E A SOCIEDADE CIVIL EM UM ESPAÇO PÚBLICO DE COMUNICAÇÃO DA CIÊNCIA
}

Cláudia França Prieto

Belo Horizonte

2013 
Cláudia França Prieto

\section{CAFÉS CIENTÍFICOS - INTERAÇÕES ENTRE A COMUNIDADE CIENTÍFICA E A SOCIEDADE CIVIL EM UM ESPAÇO PÚBLICO DE COMUNICAÇÃO DA CIÊNCIA}

Tese apresentada ao Programa de PósGraduação da Faculdade de Educação da Universidade Federal de Minas Gerais, como requisito parcial para obtenção do título de Doutora em Educação.

Orientadora: Profa. Dra. Silvania Sousa do Nascimento 
Autorizo a reprodução e divulgação total ou parcial deste trabalho, por qualquer meio convencional ou eletrônico, para fins de estudo e pesquisa, desde que citada a fonte e respeitados os direitos autorais.

Catalogação na publicação Serviço de Biblioteca e Documentação

Departamento de Pós-Graduação em Educação da Universidade Federal de Minas Gerais.

PRIETO, Cláudia França

Cafés científicos - interações entre a comunidade científica e a sociedade civil em um espaço público de comunicação da ciência / Cláudia França Prieto; Orientadora Profa. Dra. Silvania Sousa do Nascimento - Belo Horizonte - MG, 2013.

Tese (Doutorado) - FaE - UFMG - Faculdade de Educação da Universidade Federal de Minas Gerais. Programa de Pós-Graduação em Educação: Educação Escolar: Instituições, Sujeitos e Currículos.

(LC HV- a preencher pela biblioteca) 
Para minhas três mães:

Beatriz, minha mãe, companheira incansável de todas as horas; Tia Sofia, fada madrinha dos contos de fadas; Minha avó Eponina, que se foi em 2012, mãe de todos nós. 


\section{AGRADECIMENTOS}

À Silvania, pelos projetos e oportunidades inesquecíveis nesses quase quatro anos de doutorado.

Ao Ronan, meu amor, parceiro de todas as horas, de todos os momentos, muito obrigada pela presença constante.

À Ana Rodarte, de aluna a grande amiga e parceira.

Aos alunos do curso de Formação Intercultural de Educadores Indígenas, pelas suas trajetórias de vida, pelos seus deslocamentos em busca de conhecimento e formação. Obrigada por me ensinarem como a vida pode ser simples!

Aos colegas da equipe CVN e ao nosso tutor, aos colegas do FIEI.

Aos colegas de orientação, sentirei saudades dos nossos encontros, das trocas, das boas contribuições, da torcida que fazemos uns pelos outros.

À equipe do Barômetro - Ciência, café e debate:

Rádio 104,5 UFMG Educativa - em especial, Elias, Pacífico, Judson, Cláudio, Taís Marinho, Raquel, Otávio Zonato, Alessandra Dantas, Lidiane Barbosa, Antônio Tinoco, Luíza. Aos demais técnicos e alunos envolvidos nas transmissões do Barômetro, muito sucesso para todos vocês!

Centro Cultural UFMG - especialmente, Profa. Sônia Queiroz, Cida, Alice, Ana, Gema, Justino, "Seu" Valter, Marcos - obrigada especial a todos vocês, sentirei saudades! Aos seguranças, estagiários, moças da limpeza e demais profissionais envolvidos.

Diretoria de Divulgação Científica da UFMG — Lélia, Acácia, Naiemer, Mara, Edilene, Polyana, Juliana. Aos meninos queridos, Reinaldo e Mateus.

LEME - Douglas, Bárbara e Endy, "braços direitos" nas tardes de quintafeira! Sucesso para todos vocês!

CAC/UFMG - Ivonildo, Diano, Felipe e Hector. Técnicos e companheiros nas tardes de quinta!

Ao Marcos, pelo transporte com muito bom humor!

Aos debatedores que participaram dos programas.

Aos músicos, que se engajaram e acreditaram no projeto e se propuseram a participar de forma voluntária.

Sem essas equipes, sem essas pessoas, a realização desse projeto não teria sido possível. A todos vocês, muito obrigada e muitas, muitas saudades! 


\section{RESUMO}

Esta tese foi desenvolvida a partir do Projeto "Barômetro - Ciência, café e debate", um Café Científico promovido pela Diretoria de Divulgação Científica da UFMG em parceria com o Centro Cultural UFMG e a Rádio 104,5 UFMG Educativa. Os Cafés Científicos são espaços públicos que se configuram como um lugar de encontro da comunidade científica e da sociedade civil para discutirem sobre ciência. Partimos da hipótese de que nesse encontro emergem imagens da ciência no discurso da comunidade científica e imagens da ciência no discurso da sociedade civil. O quadro teórico da investigação destacou os modelos de comunicação pública da ciência de Lewestein (2003) e a concepção de dispositivos pedagógicos de Bernstein (1990), além dos conceitos de multimodalidade e de ambientes multimodais de Kress (2004) e Martin, Daly e Thurston (2005) e os processos do design instrucional de Smith e Ragan (1999). Três contextos diferentes de Cafés Científicos foram analisados para a focalização nas interações discursivas entre a comunidade científica e a sociedade civil, promovidas pelo dispositivo pedagógico multimodal criado pelo projeto. A abordagem qualitativa foi o procedimento metodológico principal para a coleta de informações e a análise temática, segundo Riessman (2007), foi empregada para a categorização de temas e subtemas em um evento selecionado para análise. As conclusões foram orientadas por esse processo de categorização e apresentaram as imagens da ciência presentes no discurso dos representantes da comunidade científica e da sociedade civil. A contribuição mais significativa da parte da comunidade científica foi apresentar a ciência como uma atividade complexa, não linear, que possui seus conflitos internos, comete erros e não consegue apresentar soluções para os problemas de forma geral. Da parte da sociedade civil, foi a de demonstrar pouca familiaridade com os processos e as formas de funcionamento da atividade científica, ao entrar no âmbito da discussão sobre ciência quando vivenciam problemas a ela relacionados.

Palavras-chave: Cafés Científicos; Comunicação Pública da Ciência; Dispositivos Pedagógicos; Multimodalidade; Design Instrucional. 


\begin{abstract}
This thesis was developed from the project "Barômetro - Ciência, café e debate", a Science Cafe promoted by Diretoria de Divulgação Científica da UFMG in partnership with Centro Cultural UFMG and the institutional radio team, 104,5 UFMG Educativa. Science Cafes are public spaces that are configured as a meeting place for the scientific community and civil society discuss about science. This thesis considers the hypothesis that from these meetings can emerge images of science on the speech of the scientific community representatives and images of science on the speech of civil society representatives. The theoretical research highlights the models of public communication of science of Lewestein (2003) and Bernstein's (1990) conception of pedagogical devices, beyond the concepts of multimodality and multimodal environments of Kress (2004) and Martin, Daly and Thurston (2005) and the processes of instructional design of Smith and Ragan (1999). Three different contexts of Science Cafes were analyzed to focus on discursive interactions between scientific community and civil society promoted by the multimodal pedagogical device created by the project. The qualitative approach was the main methodological procedure for information collecting and the thematic analysis of Riessman (2007) was used for the categorization of themes and subthemes at one event selected for analysis. The conclusions were guided through this process of categorization and showed images of science presented in the discourse of the scientific community and of civil society representatives. The most significant contribution of the scientific community was to present science as a complex and nonlinear activity, which has its internal conflicts, that makes mistakes and that cannot provide solutions to the problems in general. On the part of civil society, the most significant contribution was to demonstrate little familiarity with the processes and ways of working of scientific activity, entering in the context of science discussion when they experience problems related to it.
\end{abstract}

Key words: Science Café; Public Communication of Science; Pedagogical Devices; Multimodality; Instructional Design. 


\section{LISTA DE FIGURAS}

Figura 1 - A Lição de Anatomia do Dr. Tulp, Rembrandt, 1632 ....................... 26

Figura 2 - Pop card Barômetro Ciência e Dengue ……………………......... 68

Figura 3 - Pop card Barômetro Ciência e Samba ……………………......... 68

Figura 4 - Esquema do Público Participante presencial e o os estímulos do

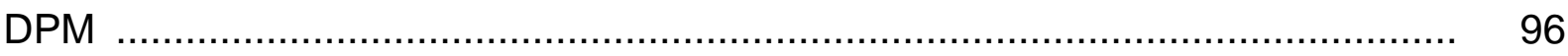

Figura 5 - Esquema do Ouvinte Internet .............................................. 96

Figura 6 - Esquema do Ouvinte Rádio ...................................................... 96

Figura 7 - Esquema do Ambiente Multimodal ............................................. 97

Figura 8 - Esquema do Fluxo de elaboração das perguntas e suas

distribuições entre os espaços público e privado ........................................... 124 


\section{LISTA DE FOTOS}

Foto 1 - Barômetro Ciência e Dengue, Sala do Piano, Centro Cultural UFMG .. 64

Foto 2 - Público participante recebe instruções para manusear o tablet,

Barômetro Ciência e Samba, Sala do Piano, Centro Cultural UFMG

Foto 3 - Visão geral da Sala do Piano, Centro Cultural UFMG, Barômetro

Ciência e Sala de Aula

Foto 4 - Projeção da Esfera Semântica e das perguntas enviadas pelo tablet,

Barômetro Ciência e Inclusão social

Foto 5 - Instrumentos à espera dos músicos, minutos antes do programa ir ao ar, Barômetro Ciência e Sala de aula

Foto 6 - Barômetro Ciência e Sala de aula

Foto 7 - Público pariticipante elabora perguntas no teclado virtual, Barômetro

Ciência e Inclusão Social 99

Foto 8 - Público participante manuseia tablet, Barômetro Ciência e Dengue ..... 100

Foto 9 - Peça de roupa confeccionada com material reciclado que foi apresentada ao público por um dos debatedores convidados, Barômetro Ciência e Design

Foto 10 - Barômetro Ciência e Samba, minutos antes do programa entrar no ar - Sala do Piano, Centro Cultural UFMG

Foto 11 - Público participante dança no Barômetro Ciência e Dengue,

Sala do Piano, Centro Cultural UFMG 


\section{LISTA DE QUADROS}

Quadro 1 - Cafés Científicos do British Council com participação do Brasil ....... 35

Quadro 2 - Debatedores — perfis gerais ................................................... 57

Quadro 3 - Debatedores — perfis detalhados ………............................... 57

Quadro 4 - Relação entre temas propostos e temas definidos ......................... $\quad 59$

Quadro 5 - Critérios de escolha — relação apresentação musical x temas ...... 62

Quadro 6 - Textos do material de divulgação dos programas do "Barômetro"

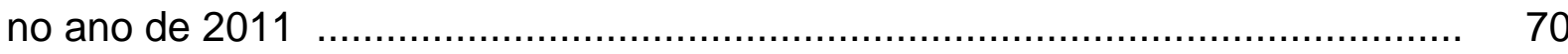

Quadro 7 - Relação — tríade do Barômetro x processos de design e instrução 73

Quadro 8 - Estrutura Conceitual: Bernstein, Lewestein e os três contextos ...... 101

Quadro 9 - Relação entre objetivos específicos e procedimentos metodológicos 107

Quadro 10 - Relação Tempo x Capital de Fala dos participantes do

"Barômetro" Ciência e Dengue .................................................................. 121

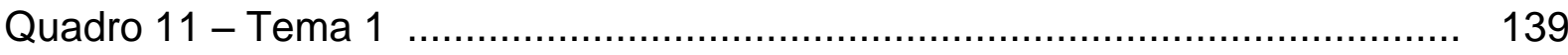

Quadro 12 - Tema 2 ............................................................ 141

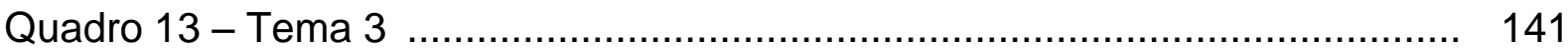

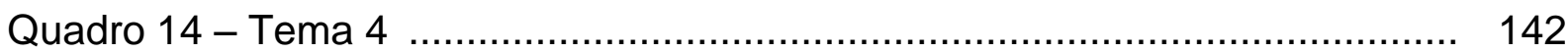

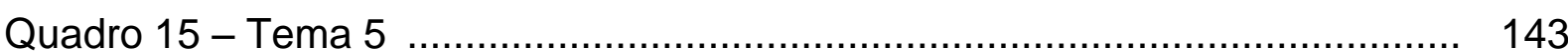

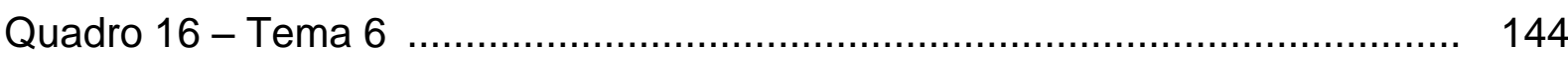

Quadro 17 - Tema 7 .................................................................... 145

Quadro 18 - Tema 8 .............................................................. 146

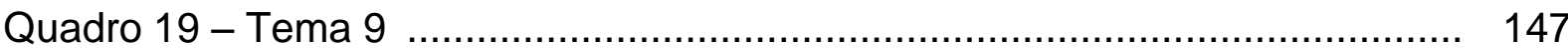

Quadro 20 - Tema 10 A ………...................................................... 149

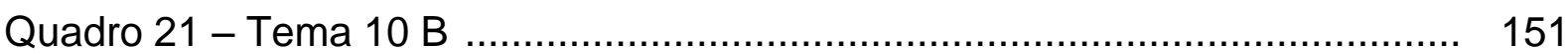

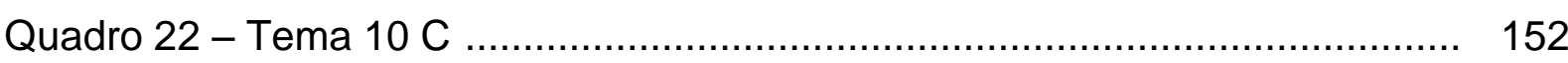

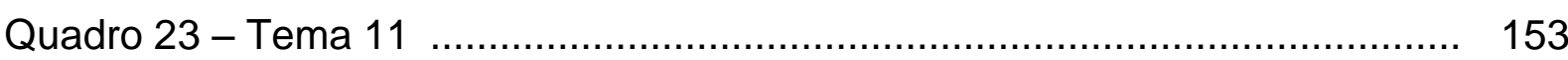

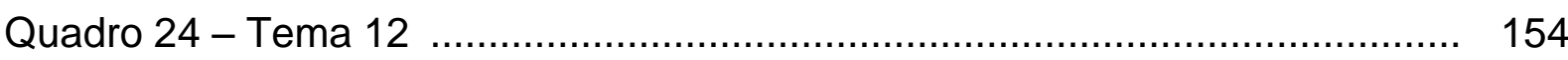

Quadro 25 - Tema 13 ............................................................... 156

Quadro 26 - Tema 14 ........................................................... 157

Quadro 27 - Tema 15 .................................................................. 159

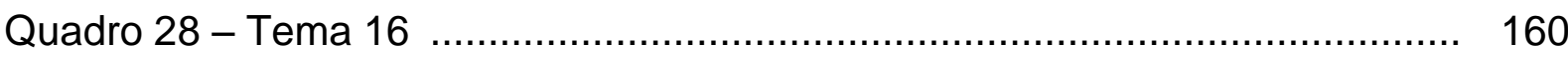

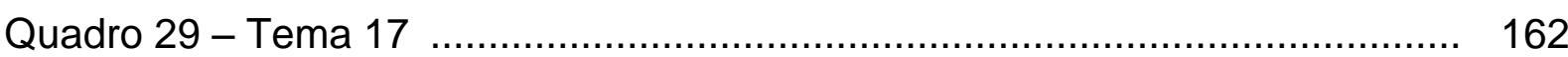


Quadro 30 - Mapeamento geral de temas e subtemas categorizados e os tempos de debate sobre eles no programa 169

Quadro 31 - Tempos de debate dos temas e subtemas categorizados, no programa

Quadro 32 - Relação entre o tempo total do programa e o número de temas categorizados

Quadro 33 - Ocorrências das imagens da ciência presentes no discurso da Comunidade científica e da Sociedade civil 


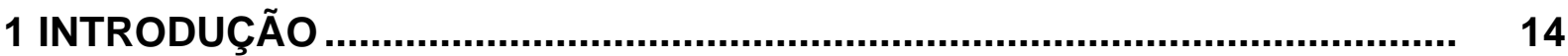

1.1 A relação entre produção e pesquisa ....................................................... 23

1.2 Organização dos capítulos .................................................................. 23

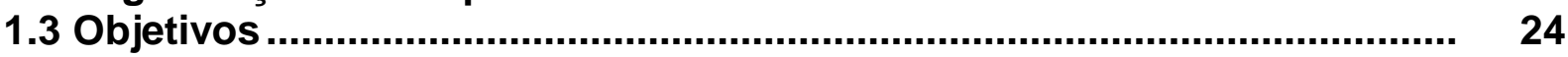

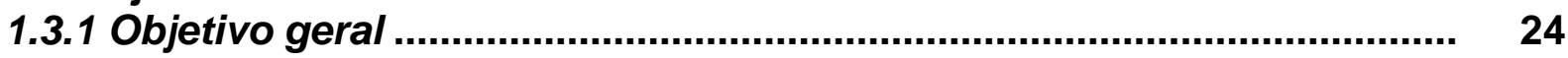

1.3.2 Objetivos específicos...................................................................... 25

2 CAFÉS CIENTÍFICOS E A CONTEXTUALIZAÇÃO HISTÓRICA.................... 26

2.1 Os Cafés Filosóficos ou o "Café Philo" ................................................. 29

2.2 Os Cafés Científicos - da filosofia de balcão à ciência de balcão .......... 33

3 OS TRÊS CONTEXTOS DE COLETA DE DADOS........................................ 40

3.1 Primeiro contexto de coleta de dados: Um Café Científico Júnior sobre aquecimento global.

3.2 Segundo contexto de coleta de dados: 0 "Café des Techniques",

Paris, França..

3.3 Terceiro contexto de coleta de dados - o contexto desta pesquisa ........

3.3.1 O projeto "Barômetro - Ciência, Café e Debate" - a construção de um dispositivo pedagógico

3.3.2 A seguir, o Projeto Barômetro - ciência, café e debate.

3. 3 3 Da concepção à produção - o Design Instrucional o o papel do Designer

3.3.4 Design instrucional ................................................................. 52

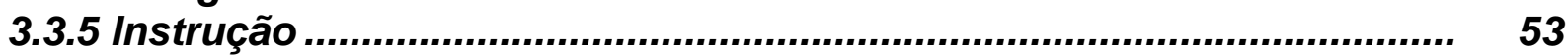

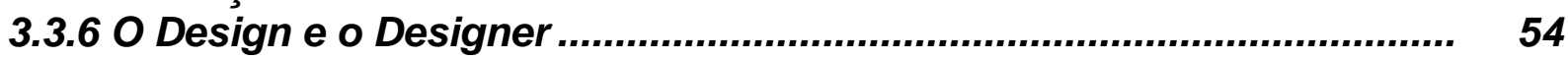

3.3.7 Processos do Design Instrucional.................................................... 55

3.3.8 A tríade em ação - instrução e design.............................................. 56

3.3.9 Relação entre a tríade do "Barômetro" e os processos de design e instrução.

4 COMUNICAÇÃO PÚBLICA DA CIÊNCIA ................................................ 74

5 DISPOSITIVOS PEDAGÓGICOS MULTIMODAIS - CONSTRUIR UM

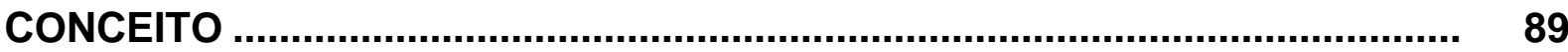

5.1 Os termos multimodalidade e multimídia ............................................... 90

5.2 Ambientes multimodais ..................................................................... 93

5.3 Dispositivo pedagógico multimodal ......................................................... 94

6 ESTRUTURA CONCEITUAL.................................................................. 101

7 INDICAÇÕES METODOLÓGICAS ............................................................. 103

7.10 universo da coleta de informações...................................................... 103

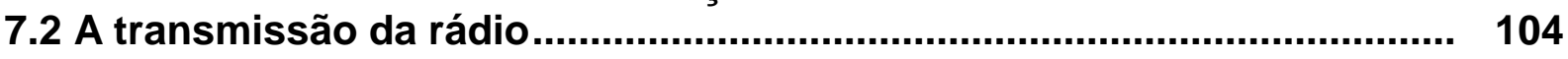

7.3 A interface da internet e o Twitter — o público ouvinte........................... 105

$7.4 \mathrm{O}$ caderno de assinaturas e o caderno de opiniões................................. 105

7.5 A esfera semântica............................................................................. 106

7.6 A escolha das perguntas ou comentários - a "repórter tablet" e sua

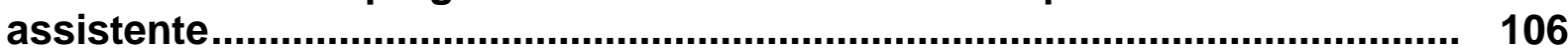

7.7 Diário de bordo - o caderno de campo................................................ 106 


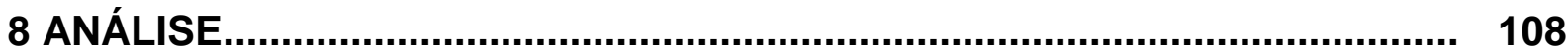

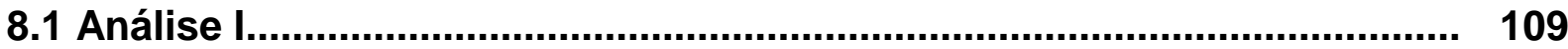

8.1.1 Lewestein e Bernstein e o "Barômetro - ciência, café e debate" ...... 109

8.1.2 A Esfera Semântica — os elementos geradores da interação .............. 116

8.2 Análise II..................................................................................... 117

8.3 Análise temática ............................................................................. 117

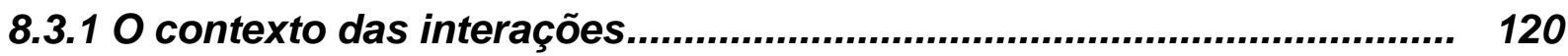

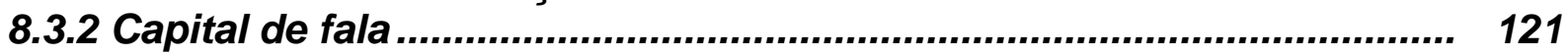

8.3.3 Análise das interações com a Esfera Semântica - do virtual para a oralidade e o discurso radiofônico / o espaço público e o espaço privado. 122

8.3.4 Análise das interações - temas e subtemas ....................................... 125

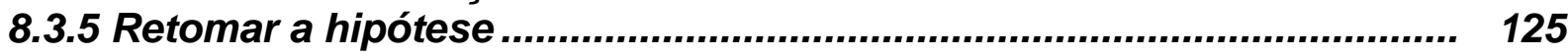

8.3.6 O cenário das interações............................................................... 126

8.4 Caracterizar o ambiente descontraído ............................................... 127

8.4.1 As noites de debate no Centro Cultural ............................................. 127

8.4.2 A desconstrução de práticas - "chamar o cientista às falas"............. 128

8.4.3 $O$ público participante e a liberação da emissão ................................. 130

8.4.4 Ciência e Dengue - O médico, a dona de casa, a diarista, o músico e o

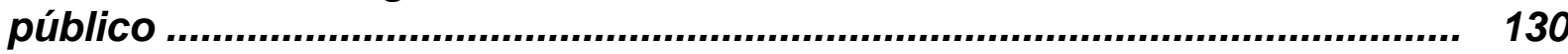

8.4.5 Particularidades da noite................................................................ 132

8.4.6 A comunidade científica e a sociedade civil....................................... 133

8.5 Caracterizar o ambiente multimodal.................................................... 133

8.5.1 A relação entre campos do conhecimento ......................................... 134

8.5.2 Perguntas tablet - entre a escrita e a oralidade e o "delay"............... 134

8.5.3 Palavras da noite - campos semânticos Ciência e Dengue ................ 135

9 TEMAS E SUBTEMAS .......................................................................... 137

9.1 Conceito de tema nesta pesquisa.................................................... 137

9.2 Nomenclaturas ................................................................................ 138

9.3 Número total de registros no banco de dados ....................................... 138

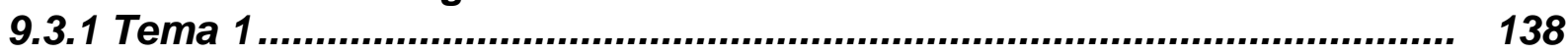

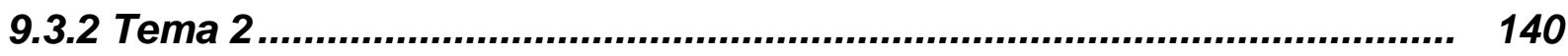

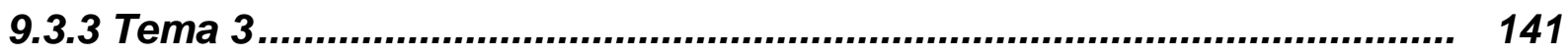

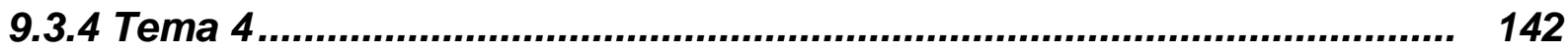

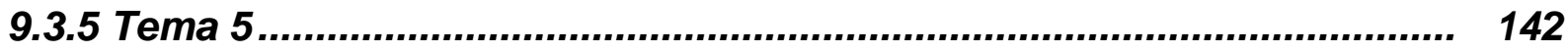

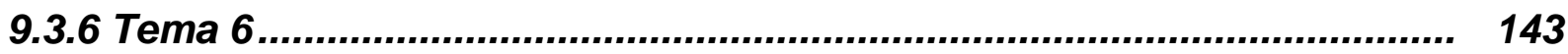

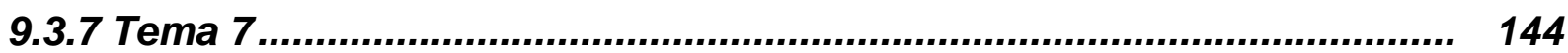

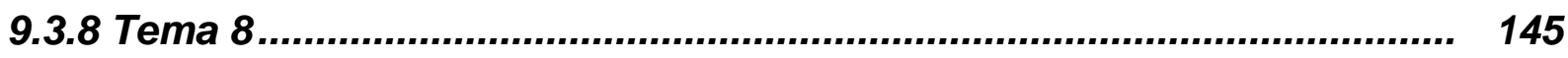

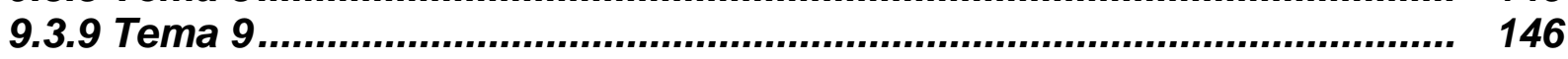

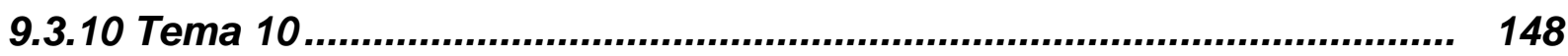

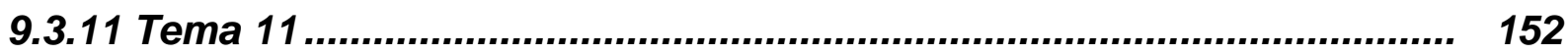

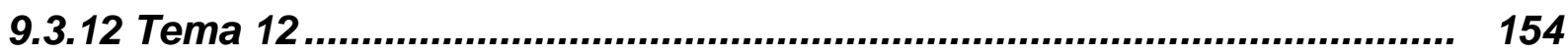

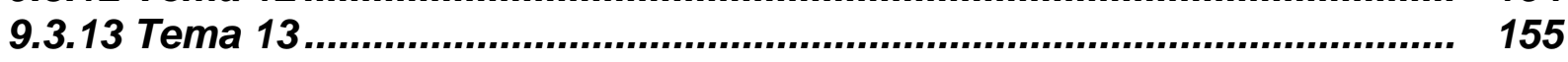

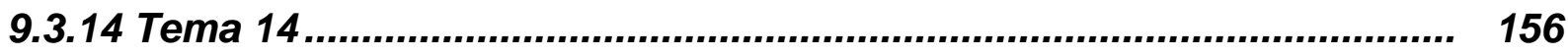

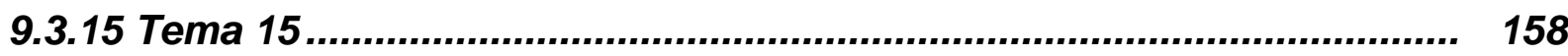

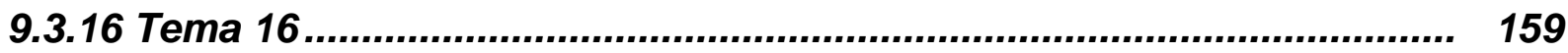

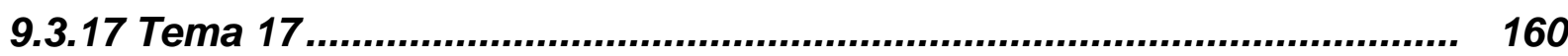

9.4 Ao final do debate, a opinião do público participante ............................. 162

10 RESULTADOS E CONCLUSÕES ............................................................. 164

10.1 Mapeamento geral das categorias de temas e subtemas...................... 164 
10.2 A ciência na voz dos atores do Barômetro Ciência e Dengue

10.3 A comunidade científica e a ciência

10.4 A sociedade civil e a ciência

10.5 A ciência, a sociedade civil, a comunidade científica, as interações discursivas públicas, o dispositivo pedagógico multimodal: 0

Barômetro - Ciência, café e debate

REFERÊNCIAS

APÊNDICES

APÊNDICE A - Relação dos dados coletados no Café 2 - Projeto "Barômetro"

- Ciência, café e debate

APÊNDICE B - Perguntas selecionadas pela Equipe da Rádio ................... 197

APÊNDICE C - CAFÉ —Diário de Bordo ................................................. 201

APÊNDICE D - Estudo de Público ............................................................. 204 


\section{INTRODUÇÃO}

Os Cafés Científicos são espaços fora do ambiente acadêmico que se configuram como lugar de encontro da comunidade científica com a sociedade civil para se discutir sobre ciência. Com base nessa constatação, esta tese investigou contextos de Cafés Científicos a partir da hipótese de que, nesses espaços, emergem imagens da ciência no discurso da comunidade científica e imagens da ciência no discurso da sociedade civil. Detalhadamente, por meio das interações discursivas públicas entre a comunidade científica e a sociedade civil promovidas pelo dispositivo pedagógico multimodal criado pelo Projeto "Barômetro - Ciência, café e debate"1, emergem, de um lado, elementos relacionados à produção, validação, difusão, comunicação, articulação e desenvolvimento da ciência, e, de outro, elementos relacionados ao entendimento, apropriação, utilização, mitificação, aceitação, refutação, negação e discussão da ciência. Esses fatores orientaram a construção das categorizações das imagens da ciência propostas nesta pesquisa nos procedimentos de análise.

O Projeto "Barômetro - Ciência, café e debate" foi um Café Científico promovido pela Diretoria de Divulgação Científica da Universidade Federal de Minas Gerais (UFMG) em parceria com o Centro Cultural UFMG e a Rádio 104,5 UFMG Educativa. O "Barômetro" incorporou em sua concepção uma série de inovações que, agregadas à ideia dos Cafés Científicos, conferiram sua originalidade.

Nesse espaço concebido para favorecer a interação entre a comunidade científica e a sociedade civil, quais seriam os fatores que indicam se há uma relação entre ciência e sociedade? Quais seriam os reflexos da atividade da produção científica que surgem nesse espaço? Quais seriam os reflexos da atividade da comunicação pública da ciência? Como a sociedade civil lida com as questões científicas neste início de século XXI? Como a sociedade percebe a atividade científica? Como a comunidade científica lida com a sociedade civil? Os Cafés Científicos e suas dinâmicas de funcionamento seriam realmente espaços propícios para o surgimento de respostas em relação a esses questionamentos?

Repositório Digital UFMG. Projeto "Barômetro - Ciência, café e debate". Disponível em: $<$ https://dspaceprod02.grude.ufmg.br/dspace/handle/RDUFMG/812>. 
Segue a pergunta que direcionará a pesquisa: Como os contextos dos Cafés Científicos contribuem para evidenciar as relações estabelecidas entre a ciência, a comunidade científica e a sociedade civil, sob a ótica da comunicação pública da ciência?

Um autor e um grupo de autores, cujas publicações possuem um intervalo de tempo de cerca de doze anos entre uma e outra, trouxeram posicionamentos interessantes sobre os Cafés Científicos com reflexões também interessantes para a hipótese proposta.

Em 1998, o pesquisador Pablo Jensen publicou um texto no jornal francês Le Monde a respeito dos Cafés Científicos e os situou como uma iniciativa modesta, porém, operacional, para conectar com maior profundidade ciência e sociedade. De acordo com sua opinião, a ciência estava em crise (o texto foi publicado em 22 de dezembro de 1998) e ele se perguntava - o que fariam os "Cafés" no meio das discussões "atuais" a respeito da reforma da pesquisa científica? E mais, para quem se supõe servir a pesquisa científica? Jensen (1998) afirmou que para essa pergunta existiam dois tipos de justificativa - um, a ciência permite a todos conhecer o mundo, e dois, progredir através da tecnologia. Do ponto de vista do conhecimento, ele pontuou, a ciência produz, sobretudo, saberes especializados, amplamente incompreendidos pelos cidadãos, inclusive pelos pesquisadores de outras disciplinas. Como consequência disso, surge a falta de enraizamento da ciência na cultura.

Segundo Jensen (1998), a pesquisa científica, reconhecida institucionalmente, é feita pelo que ele chamou de "cientistas de aeroporto" ou os homens de negócio da ciência. No que diz respeito aos avanços tecnológicos, Jensen completou, verificou-se que as relações entre a excelência na pesquisa fundamental e o bem-estar, para a maioria, são pouco evidentes. Dessa forma, os Estados Unidos da América do Norte, país considerado por ele como a maior potência científica na época, possuía índices de desenvolvimento efetivo comparáveis aos de regiões bem menos avançadas cientificamente, embora praticasse políticas de saúde inteligentes. Ou ainda, que se pode pensar que existe tecnologia suficiente para resolver os grandes problemas de base da humanidade como a fome, por exemplo. Isso sem contar com os deslizes tecnologicamente constatados (Chernobyl) ou os que estariam por vir (plantas geneticamente modificadas, clonagem) que inspiram uma desconfiança legítima da população em torno dos cientistas, prontos para minimizar os riscos. 
Diante dessa desconfiança ele questionou: Que respostas podem trazer os cientistas? Se não fizermos uma reflexão profunda sobre o que são as ditas ciências "modernas", sobre o que poderia ser uma cultura científica, obviamente torna-se necessário estabelecer uma articulação eficaz entre ciência e sociedade civil, que permita, aos pesquisadores e aos cidadãos, encontrarem-se e confrontarem suas ideias. Um dos problemas, prosseguiu Jansen (1998), é que as teorias científicas não são expressamente construídas para serem compreendidas pela grande maioria. Cabe a elas serem "somente" operacionais e não contradizerem muito os dados experimentais.

A compreensão pelo mais comum dos mortais poderia ser a "cereja do bolo" de uma explicação científica, mas isso não é nem prioridade, nem necessário, assim como a criação de empregos por uma empresa do jogo capitalista, onde o objetivo principal é o de gerar lucros.

Jensen (1998) objetou, não se pode exigir que as leis da Natureza sejam simples, embora sejam pouco contestáveis, mas não deveriam as pessoas impedir de dedicar muita energia para a "digestão" dos saberes científicos, de sua implementação na cultura. Ele disse que as novas formas de popularização da ciência desaceleraram a pesquisa no sentido atual. Pode ser, no entanto o jogo vale a pena e Jensen (1998) trouxe uma provocação — perdão a algumas das centenas de milhares de artigos científicos escritos a cada ano, dos quais a maioria mal são lidos, tratem de situar melhor as questões das pesquisas para a sociedade, de expressar conhecimentos em termos claros, de relacioná-los aos outros domínios científicos.

Suas palavras e provocações compuseram a base do que viria depois, para o lugar aonde ele queria chegar. Para ele, tudo isso é certamente abstrato e pouco construtivo. Jensen (1998) apresentou, então, o que ele chamou de uma iniciativa modesta, porém operacional para conectar de forma mais profunda ciência e sociedade, os Cafés Científicos. Os encontros nos "Cafés" constituem em um exercício mais difícil para o cientista do que escrever um artigo científico, todavia indispensável para o contexto atual e que poderíamos erroneamente pensar que seriam benéficos apenas para o público. É essencial mostrar que os cientistas são pessoas como as outras e que existe no interior das ciências as polêmicas, as incertezas. Modestamente, disse Jansen (1998), os "Cafés" indicam uma pista possível para reconciliar a sociedade com uma ciência mais próxima, mais cidadã, e deveriam constituir como um dos objetivos para reforma significativa da instituição científica. 
Doze anos depois, o grupo de autores Bagnoli, Dallas e Pacini elaborou, em 2010, um webbook no qual relataram suas experiências em Cafés Científicos a partir das suas bases acadêmicas de origem, University of Leeds (Leeds, Reino Unido) e Universitá di Firenze (Firenze, Itália), em diversos locais do mundo.

Para esses autores, a relação entre ciência e sociedade tem se tornado complexa porque eles consideram que existem diversidades dentro do campo da ciência e nas sociedades de forma geral. A ciência hoje está presente tanto nos Centros de Ciência quanto nas semanas de ciência, nas atividades de extensão, nas modernas tecnologias. A comunicação da ciência agora envolve desde debates e pesquisas, demonstrações, músicas populares e jogos, até as redes sociais como o Twitter, o Facebook e o Youtube. Há um movimento para fora das tradicionais estruturas acadêmicas e, nesse movimento, estão os Cafés Científicos.

Ao oferecerem uma experiência direta da academia com o público, os "Cafés" podem construir pontes entre o que esse trio de autores chamou de o velho mundo - universidades e métodos tradicionais - e o novo mundo - informalidade, engajamento, internet. O elemento-chave desses eventos é a sua flexibilidade podem ser utilizados para a educação, a controvérsia, o treinamento, a comédia, a informação médica, o engajamento ecológico, os argumentos éticos, as análises históricas ou as pesquisas recentes e de ponta. Sua flexibilidade está na dinâmica criada que possibilita incorporar as mudanças sociais e tecnológicas. Eles não precisam repudiar as tradicionais instituições científicas, mas refletem e são produto da mudança social e, com isso, movem-se na mesma direção do mundo moderno.

Enquanto a ciência possui métodos universalizados, as culturas são localmente lapidadas. Cada "Café" precisa se engajar nos modos, comportamentos, crenças e formas de pensamento locais. Eles formam uma rede, não uma instituição.

As possibilidades de operacionalizar a relação entre ciência e sociedade atribuída aos "Cafés" pelos autores citados fazem com que se abram as portas para a emergência dos posicionamentos de ambas as esferas, posicionamentos esses que serão aqui traduzidos e analisados como imagens da ciência.

Indicadores levantados em uma pesquisa sobre imagens da ciência e percepção pública da ciência colaboraram também para fundamentar a hipótese proposta.

Nos anos de 2002 e 2003, a Rede Ibero-Americana de Indicadores de Ciência e Tecnologia (RYCYT/CYTED) e a Organização de Estados Ibero-Americanos (OEI) 
realizaram uma pesquisa piloto em quatro países (Argentina, Brasil, Espanha e Uruguai) sobre percepção pública da ciência. A pesquisa forneceu, segundo Izique e Moura (2004), indicações preciosas sobre o imaginário social em relação à ciência e tecnologia nesses países.

Através dessa pesquisa, foi possível levantar indícios em relação ao grau de compreensão de determinados assuntos do conhecimento científico e tecnológico, ao consumo de informação científica nesses países e à participação efetiva dos cidadãos em movimentos e debates sobre temas controversos de ciência e tecnologia. $O$ imaginário social desses países expressou a prevalência de uma imagem tríplice da ciência que tem, nas grandes descobertas, no avanço tecnológico e na melhoria da vida humana, sua representatividade.

Conforme Polino (2003), a pesquisa englobou três eixos que se entrelaçaram e prevalecem no imaginário social dos países estudados, são eles, o imaginário social, a comunicação da ciência e a participação cidadã. $O$ autor ressaltou também que existe $o$ entendimento de que a ciência se realiza, projeta e impacta em sociedades de indivíduos distintos. Isso fez com que se levantasse a pertinência de um enfoque particular sobre sociedades locais que modificam, se apropriam, moldam, utilizam, discutem ou refutam a ciência de acordo com suas normas, crenças, valores, comportamentos e suas estruturas econômicas e produtivas.

Mas, mesmo após reconhecer esse impacto localizado, Polino (2003) citou o fracasso do grande projeto da ciência a serviço do destino nacional e da incapacidade da sociedade em articular laboratórios das universidades com oficinas e fábricas, ensino com valorização do conhecimento, ciência e política com a solução de problemas sociais. O autor abordou o divórcio entre ciência e sociedade e afirmou que existem manifestações concretas. De maneira geral, para ele a sociedade não espera que a ciência solucione seus problemas mais urgentes.

Polino (2003) opinou que se deve fomentar a participação dos cidadãos para a democratização do conhecimento, mesmo que sob condições práticas ainda desconhecidas. E mais, a sociedade deve se envolver na definição da trajetória da ciência e da tecnologia.

Surgiu, então, a pergunta - estaria a comunidade científica preparada para dialogar com a sociedade e reconhecer nela uma parceria possível de sua trajetória? O que a comunidade científica teria a dizer sobre isso?

Em uma tentativa para saber um pouco sobre o lado da ciência ou como os 
cientistas veem a ciência e como esta é colocada por eles, realizou-se uma busca a respeito das imagens da ciência na visão dos cientistas. Por meio de uma procura nas bases de dados acadêmicas, constatou-se que as pesquisas são mais dirigidas ao público do que aos cientistas (SCOLES, 2012).

Coll, Lay e Taylor (2008) colocaram, em um texto sobre visões de cientistas a respeito dos temas religião e superstição, que as inovações científicas e tecnológicas são realizadas de acordo com motivações, interesses e valores da comunidade científica, mais do que da sociedade como um todo. Eles também consideraram que, o grande impacto dessas inovações seria menos problemático se tivessem maior representatividade dos valores e das questões culturais das sociedades de forma geral.

Segundo esses autores, para se engajar no debate sobre questões científicas, é necessário certo entendimento acerca de como a ciência funciona, da natureza da ciência. Muito do sucesso alcançado pela ciência é atribuído ao chamado método científico e aos altos padrões de evidência das afirmações e teorias científicas. Mas eles se perguntam: Como a ciência funciona? Como os cientistas obtêm seus dados? Qual dado pode ser considerado bom? Quais são as "regras do jogo" na ciência? Seria a ciência um corpo codificado do conhecimento difícil de ser desafiado?

O que desses questionamentos poderia surgir no discurso dos representantes da comunidade científica presentes nos programas do "Barômetro"? A sociedade civil teria esse entendimento de que falam os autores?

A investigação proposta situou os Cafés Científicos como um espaço de encontro da ciência com a sociedade, em um ambiente que favoreceu a interação entre eles. Dito isso, partiu-se da proposição de que questões relacionadas às imagens da ciência da parte da sociedade e da parte da comunidade científica poderiam aflorar nas interações criadas nos contextos dos Cafés Científicos.

Foram três os contextos de coleta de dados desta pesquisa. Os dois primeiros serviram para orientar as ações de concepção e produção do terceiro contexto, o "Barômetro". As interações ocorridas nesses dois contextos e suas formas de organização contribuíram também para o entendimento das proposições dos referenciais teóricos principais ao articular as propostas dos autores com as ocorrências do debate.

O primeiro contexto foi um Café Científico desenvolvido pelo projeto "Memória 
e História de Técnicas e Tecnologias contadas nos espaços museográficos do CEFET-MG, em Cafés de Ciência e Tecnologia”. Esse contexto se constituiu de três eventos entre 2009 e 2010 ocorridos entre o Centro Federal de Tecnologia de Minas Gerais (CEFET-MG) e a Escola Estadual Maurício Murgel na modalidade "Junior", ou seja, organizados em espaços escolares.

O segundo contexto se referiu ao Café des Techniques do Conservatoire National de Arts et Métiers, Paris, França, em fevereiro de 2011. Os Cafés Científicos fazem parte da programação anual de eventos desse museu desde 2002 e esse, em particular, trouxe uma amostra de como eles acontecem no país que lhes deu origem.

O terceiro contexto, o "Barômetro CEFET - Ciência, café e debate", teve seus procedimentos de pesquisa e produção balizados pela concepção de Dispositivo Pedagógico de Bernstein (1990), para sua elaboração, e os processos do Design Instrucional, como diretrizes para seu funcionamento. Seu diferencial em relação aos demais contextos pesquisados residiu nos elementos inovadores que compuseram sua tríade ${ }^{2}$ - a Conferência Pública, o Programa de Rádio $^{3}$ e a Interface Digital.

A Conferência Pública permitiu trazer para o espaço de debate não apenas convidados da comunidade acadêmica e científica, mas convidados da sociedade civil que possuíssem algum tipo de representatividade em relação aos temas debatidos. A presença do público de forma presencial e virtual complementou esse eixo da tríade.

O Programa de Rádio incorporou uma série de novos elementos. De início, a elaboração de um script, um roteiro, que delineou o desenrolar dos debates. Nesse roteiro estavam incluídas as apresentações pela repórter âncora, a mediação com o público pela repórter dos dispositivos móveis, a apresentação musical, os blocos de debate e a participação do público.

O script foi um dos elementos-chave desse processo, pois, apesar de estabelecer um roteiro para o desenrolar do programa, foi elaborado de forma a flexibilizar seus acontecimentos e garantir a participação equilibrada das partes envolvidas - debatedores e público.

2 Projeto "Barômetro - Ciência, café e debate" registrado na Coordenadoria de Transferência e Inovação Tecnológica da UFMG.

3 Repositório Digital UFMG. Registros dos programas de rádio do Projeto "Barômetro - Ciência, café e debate". Disponível em: <https://dspaceprod02.grude.ufmg.br/dspace/handle/RDUFMG/25>. 
Outro ponto de destaque foi a dimensão formadora através da participação de alunos de cursos de graduação da instituição, principalmente do curso de Comunicação Social, na condução e mediação dos programas e na equipe de suporte técnico. Dentre as participações dos alunos destacaram-se a repórter apresentadora ou âncora, que conduziu os programas e a repórter dos dispositivos móveis, a "repórter tablet", que fez a mediação com a plateia.

A rádio web e o twitter ampliaram o espaço de debate ao permitir o alcance de outros públicos, outra audiência, que não estavam necessariamente presentes no momento da transmissão. A transmissão em tempo real também colaborou para a ampliação do espaço do debate para outros locais e outros públicos.

As apresentações musicais possibilitaram a participação de artistas vindos de projetos culturais e sociais que poderiam ter alguma relação com o tema debatido, ou não. A música proporcionou momentos de descontração entre os blocos de debate e, durante sua execução, foi possível fazer ajustes necessários para o andamento dos programas.

A Interface Digital, por meio do software da Esfera Semântica, promoveu a participação e interação do público pelo uso dos dispositivos móveis e pela elaboração de significativa quantidade de perguntas e comentários. A cada evento, foi gerada uma tabela com as combinações de palavras e os respectivos comentários ou perguntas que compuseram, mês a mês, o banco de dados do projeto. Os dados gerados poderão servir como base para pesquisas diversas, seja na área das ciências naturais, seja na área das ciências sociais.

Foram ao todo oito programas de rádio no ano de 2011, o programa do mês de abril desse ano, com o tema Ciência e Dengue, foi o escolhido para ser detalhadamente analisado nesta pesquisa.

Os Cafés Científicos e suas configurações foram apresentados por meio de sua história levantada em uma pesquisa documental em sites relacionados a esses eventos. Acompanharam sua história a retrospectiva de Bensaude-Vincent (2001), sobre Entendimento Público da Ciência, do século XVIII ao século XX, e as narrativas de Sautet (2006) a respeito dos acontecimentos no interior dos "Café Philo", os Cafés Filosóficos parisienses.

Abordagens e concepções dos últimos dez anos sobre Comunicação Pública da Ciência foram expostas por meio de uma revisão de publicações. Dentre elas, os Modelos de Comunicação Pública da Ciência de Lewestein (2003) se destacaram e 
complementaram o conjunto das referências principais.

A proposta de construção do conceito de Dispositivo Pedagógico Multimodal foi introduzida em formato de capítulo, mas se constituiu em um dos resultados desta pesquisa. A proposta desse conceito agregou à concepção de Dispositivo Pedagógico de Bernstein (1990) os recursos da multimodalidade disponibilizados para o público participante, debatedores, músicos e repórteres da rádio durante a transmissão dos programas. O conceito foi articulado aos fatos ocorridos nos programas do projeto e que se repetiram a cada evento. $O$ foco para a proposição desse conceito foi o design do contexto criado para as interações.

A abordagem qualitativa foi o procedimento metodológico principal em conjunto com a pesquisa documental. As transcrições das gravações dos programas de rádio no quadro de narrativas, o banco de dados gerado pelo software da Esfera Semântica, o caderno de assinaturas, o caderno de opiniões e o diário de bordo colaboraram para a construção dos elementos de análise.

A análise foi dividida em duas partes. A primeira parte traçou uma análise do dispositivo do "Barômetro" e dos dois primeiros contextos a partir dos referenciais teóricos principais, o conceito de Dispositivo Pedagógico de Bernstein (1990) e os Modelos de Comunicação Pública da Ciência de Lewestein (2003). A análise dos dois contextos iniciais e as proposições desses autores foram fundamentais para apurar o olhar em relação ao terceiro contexto e realizar uma abordagem detalhada e profunda de suas interações. A segunda parte analisou as interações discursivas públicas do programa Ciência e Dengue e abordou essas interações mediante os componentes da tríade e os recursos da multimodalidade. Nessa parte da análise, foram propostas categorizações das imagens da ciência a partir da hipótese da pesquisa. As imagens da ciência foram relacionadas aos posicionamentos dos debatedores e dos demais participantes, cujos posicionamentos se tornaram públicos durante a transmissão do programa. Tanto as imagens propostas quanto os posicionamentos selecionados constituíram um procedimento de interpretação do processo discursivo, que se desenrolou nas interações.

As conclusões evidenciaram resultados, inovações e contribuições dos procedimentos desenvolvidos para o projeto, que podem ser aplicados e replicados em processos de interação discursiva em diversos contextos, não somente aqueles que se relacionam à Comunicação Pública da Ciência. 


\subsection{A relação entre produção e pesquisa}

Esta pesquisa foi desenvolvida sob dois olhares - o olhar da produtora e 0 olhar da pesquisadora. Para o desenvolvimento do Projeto "Barômetro - Ciência, café e debate", duas foram as funções desempenhadas, a de produtora do evento e a de pesquisadora.

A função de produtora veio em decorrência da experiência profissional da autora na área do Design e em projetos de pesquisa e concepção de exposições que abordam temas da ciência e da tecnologia.

A função de pesquisadora aliou o processo de produção ao interesse de investigação na área de comunicação pública da ciência.

Portanto, as decisões em relação aos marcos teóricos e a execução do dispositivo criado para o "Barômetro" foram da ordem da concepção de seu design, de forma que o mesmo criasse um contexto não apenas original, como estimulador das interações que nele ocorreram e de extremo interesse da pesquisa realizada.

\subsection{Organização dos capítulos}

A organização dos capítulos procurou seguir o mesmo percurso percorrido para a construção deste estudo. A pesquisa documental, a leitura de material bibliográfico e as participações em eventos de Café Científico foram fatores de peso para o desenrolar e a elaboração do desenho de toda a pesquisa. $O$ diálogo entre 0 material teórico e o material empírico aconteceu desde o começo do trabalho e contribuiu para as tomadas de decisões tanto na elaboração da parte textual quanto na concepção dos programas do Projeto "Barômetro".

Dessa maneira, o Capítulo 2 trouxe a história dos Cafés Científicos embasados pela retrospectiva de Bensaude-Vincent (2001) sobre Entendimento Público da Ciência e pelos relatos de Sautet (2006) do seu "Café Philo".

No Capítulo 3, foram apresentados os três contextos de pesquisa - primeiro, os três eventos de Café Científico Júnior do projeto "Memória e História de Técnicas e Tecnologias contadas nos espaços museográficos do CEFET-MG, em Cafés de Ciência e Tecnologia"; segundo, o Café dês Techniques do Conservatoire National des Arts et Métiers em Paris, França; e, terceiro, o Projeto "Barômetro - Ciência, café e debate", foco principal desta pesquisa, juntamente com a concepção de Dispositivo Pedagógico de Bernstein (1990) e apontamentos sobre Design Instrucional. 
O Capítulo 4 expôs uma revisão de publicações dos últimos 10 anos a respeito da comunicação pública da ciência e mostrou com mais detalhes os Modelos de Comunicação Pública da Ciência de Lewestein (2003), concepção essa escolhida para dar suporte ao processo de análise.

O Capítulo 5 apontou a construção do conceito de Dispositivo Pedagógico Multimodal a partir do dispositivo criado para o "Barômetro - Ciência, café e debate" caracterizado pela multimodalidade, o estímulo aos sentidos de seus participantes e diversas formas de interação.

O Capítulo 6 delineou a Estrutura Conceitual da pesquisa e propôs uma estrutura para as concepções de Bernstein (1990) e Lewestein (2003) e os três contextos de coleta de dados.

O Capítulo 7 descreveu o conjunto dos procedimentos metodológicos adotados para a pesquisa e apresentou os elementos de análise.

O Capítulo 8 foi dedicado à análise dividida em Análise I - que se referiu à análise do dispositivo do "Barômetro" e os referenciais teóricos principais, Lewestein (2003) e Bernstein (1990), e introduziu os elementos geradores das interações e, Análise II - que se referiu aos procedimentos da Análise Temática e ao detalhamento do contexto das interações, o Barômetro Ciência e Dengue.

O Capítulo 9 sistematizou os Temas e Subtemas a partir do quadro de narrativas e de um conjunto de demarcadores composto pelo tempo, pelo script, pela caracterização das respostas, pelas categorizações das imagens da ciência no discurso dos falantes, pela caracterização do ambiente multimodal e pela pergunta tablet relacionada.

O Capítulo 10 evidenciou os resultados, as conclusões e as implicações da pesquisa.

\subsection{Objetivos}

\subsubsection{Objetivo geral}

Investigar as interações discursivas estabelecidas e construídas entre representantes da comunidade científica e da sociedade civil em relação à ciência durante o desenvolvimento de um dispositivo pedagógico para Cafés Científicos. 


\subsubsection{Objetivos específicos}

- Desenvolver um dispositivo pedagógico com base em interações multimodais para ser aplicado em situações de Café Científico;

- Analisar e entender o funcionamento desse dispositivo;

- Compreender como esse dispositivo estimula a comunicação pública da ciência;

- Identificar quais são as posições enunciativas dos representantes da comunidade científica;

- Identificar quais são as posições enunciativas dos representantes da sociedade civil;

- Identificar as interações discursivas que se estabeleceram entre eles;

- Identificar o público dos Cafés Científicos e quais são suas posições enunciativas;

- Identificar as formas de participação e interação do público nesse dispositivo;

- Identificar as posições enunciativas do público em relação à ciência, aos representantes da comunidade científica e aos representantes da sociedade civil. 


\section{CAFÉS CIENTÍFICOS E A CONTEXTUALIZAÇÃO HISTÓRICA}

De proscritos a estrelas, os anatomistas entram nos séculos XVII-XVIII como atores de uma peça. As dissecações eram abertas ao público que pudesse pagar os altíssimos preços dos ingressos. Os anatomistas, como atores fantasiados dos seus personagens, vestiam-se com luxuosas roupas, capas e chapéus, tornando-se excelentes oradores. As dissecações públicas eram marcadas no tempo frio, pois ainda não se sabia conservar adequadamente os corpos, e o público, a elite local, não deveria ser exposto aos odores desagradáveis da putrefação humana. (DE GRAAFF, 2003 apud TAVANO; OLIVEIRA, 2008, p. 79).

A história dos Cafés Científicos se apresenta precedida pela retrospectiva de Bensaude-Vincent (2001) acerca da Comunicação Pública da Ciência do século XVIII até o início do século XXI. A trajetória descrita por ela trouxe colaborações no sentido de compreender um pouco a relação entre ciência e sociedade nesses últimos três séculos. A conclusão a que chegou a autora ao final de seu texto levantou pistas que necessitaram atenção nos momentos de análise e conclusão. Pistas e comentários retornarão, portanto, ao final do texto. Abaixo a Figura1 ilustra uma aula da anatomia dada pelo Dr. Tulp.

Figura 1 - A Lição de Anatomia do Dr. Tulp, Rembrandt, 1632

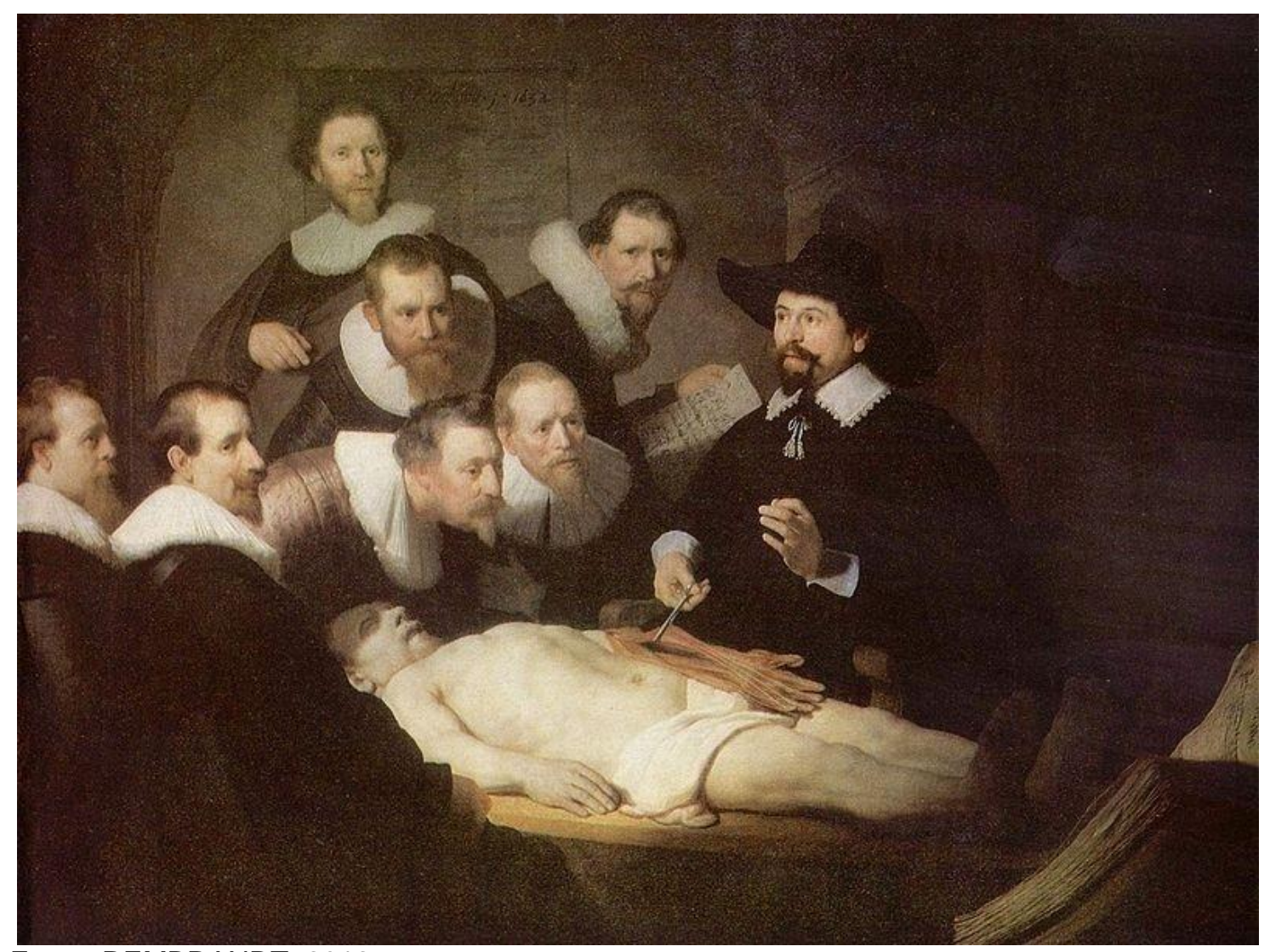

Fonte: REMBRANDT, 2012.

Nota: Óleo em tela 169,5 × 216,5 cm Mauritshuis, A Haia, Países Baixos. 
A comunicação pública da ciência tem sua origem, de acordo com BensaudeVincent (2001), no começo do século XVIII. A ciência mundana que floresceu nesse século ajudou a promover a opinião pública como uma força política. Amadoras ou acadêmicas, as práticas da ciência contribuíram para a emergência de uma "esfera pública" como uma entidade moldada através das discussões nos cafés e jornais de alguns países da Europa. Tanto na esfera política quanto na esfera científica, o espírito crítico era sempre baseado na razão e "o uso público do entendimento" eram vistos como um gesto cognitivo e político. Mas, embora essa noção formada pelo público tenha favorecido, sem dúvida, na sua participação no desenvolvimento da ciência, ela criou, ao mesmo tempo, tensões e conflitos entre os cientistas e a opinião pública.

O século XIX se iniciou em uma tentativa de colocar a ciência como a fonte do conhecimento e do poder, no centro do sistema cultural. Várias foram as iniciativas durante esse século para atingir tal objetivo. Jornais franceses e ingleses publicavam as novidades da ciência em suas colunas diárias ao lado de notícias políticas, econômicas, sociais e literárias. A criação dos folhetins científicos semanais se tornou parte integral da vida cotidiana. As Exposições Universais da segunda metade do século XIX contribuíram para presença da ciência na vida social. O crescimento acelerado da indústria celebrou o progresso e a tecnologia como sendo os principais responsáveis por promover da civilização.

A tecnologia ocupou seu lugar proeminente através das máquinas enormes exibidas nas exposições. A ciência permaneceu imperceptível nas exposições mas onipresente no discurso, embasada como precondição para o progresso tecnológico.

A dinâmica da cultura de massa foi reforçada pela abertura, na segunda metade do século XIX, de vários museus de ciência, principalmente na Europa. Todos os empreendimentos monumentais projetados para popularizar a ciência foram acompanhados por tentativas de levá-la para dentro da esfera privada burguesa. $O$ sucesso de publicações populares sobre a ciência também colaborou para o surgimento, no final desse século, da emergência de um público consumidor. A ciência popular se transformou em um negócio lucrativo. Como os livros populares não possuíam mercado cativo, o interesse do público tinha de ser continuamente estimulado e mesmo recriado. Ainda assim, a quantidade de material circulante não produzia evidência confiável da real extensão da disseminação da ciência entre o público geral. 
Para boa parte dos escritores e leitores da ciência do século XIX, porém, popularizá-la era mais do que promover sua disseminação, significava educar o público para que ele pudesse desempenhar um papel político na sociedade.

O crescimento da popularização científica no século XIX criou, todavia, uma ambiguidade central. De um lado, a ciência popular se transformou em uma lucrativa commodity com a produção industrial em massa de alguns itens, já no final do século, fato que caracterizou um fenômeno de consumo. A profissionalização do trabalho científico trouxe a divisão social entre os cientistas e o público comum, o que reforçou e estabilizou a emergência da categoria dos "consumidores científicos". De outro, a ciência popular se viu desenvolvida como uma prática alternativa da ciência. A distinção entre os produtores do conhecimento e os consumidores do conhecimento não foi, de forma alguma, um processo natural e sem problemas. Existiam controvérsias sobre a função dos periódicos científicos populares e, ao mesmo tempo, nenhum consenso. Até que ponto as práticas populares deveriam ser julgadas segundo as controvérsias da ciência ou até que ponto elas deveriam se espelhar no trabalho acadêmico dos cientistas? O fato é, o século XIX chegou ao fim com apenas uma certeza, falar em ciência popular não significou, necessariamente, falar de uma ciência popularizada.

O século XX começou com a sensação de continuação da noção de ciência popular que veio do século anterior. O que era considerada "comunicação em ciência" se restringia ao que foi divulgado pela imprensa dita especializada, isto é, os jornalistas da ciência. Essa situação deixou obscurecer no que realmente se transformou a relação entre o público e a ciência. A linguagem sustentou os sintomas dessa mudança de mentalidade. $O$ termo ciência popular não mais se refere a uma prática específica do discurso da ciência. Ele passou se referir a uma imagem da ciência refletida pela pop culture nos anúncios, programas de televisão e seriados. A noção de ciência popular como uma ciência distinta daquela desenvolvida pelos cientistas profissionais não era mais aceitável. A prática não profissional da ciência ia contra as regras da comunidade científica e foi rotulada como uma pseudociência. A ciência é única e o mundo do conhecimento ficou dividido em duas categorias: a dos cientistas, que detém o monopólio da verdade e o resto, a massa numerosa, amorfa e anônima do público. O público dos amadores iluminados do século XVIII se transformou em uma massa irracional, ignorante e facilmente trapaceável no século XX. As sociedades modernas assistiram à 
polarização da distribuição social do conhecimento. Cientistas, de um lado, como uma consequência natural da necessidade dos avanços científicos tecnológicos, lideraram um aparente inevitável abismo entre a ciência e o público, do outro. Do ponto de vista do público, esse processo poderia ser mais bem descrito como uma gradual privação do conhecimento que atinge a grande maioria das pessoas. No século $\mathrm{XX}$, cientistas e cidadãos comuns vivem em mundos diferentes.

$O$ texto de Bensaude-Vincent foi escrito no ano de 2001 e acabou por atingir o começo do século XXI. Ela afirmou, ao chegar ao século XX, que cientistas e cidadãos comuns, preferencialmente denominados nesta pesquisa de comunidade científica e sociedade civil, vivem em mundos diferentes. Embora pouco mais de dez anos tenham se passado de sua publicação, tal afirmação é uma pista a ser levada em consideração quando da análise das interações. As interações trarão indícios dessa ausência de relacionamento de que diz a autora? $\mathrm{O}$ abismo é mesmo inevitável?

Seguem, neste capítulo, a história dos Cafés Científicos e, logo após, a interessantíssima história dos "Café Philo" parisienses acidentalmente criados por Sautet (2006). As narrativas de Sautet (2006), as descrições dos encontros de domingo no Café des Phares em Paris, não possuem descrição similar em nenhum dos sites de Café Científicos pesquisados. Sua narrativa se constituiu no elemento inspirador para a construção da hipótese desta pesquisa. Sautet (2006) relatou sua história com detalhes de quem vivenciou de perto a experiência de reunir, sem querer, pessoas diversas, de diferentes classes sociais e profissões para conversar e debater sobre uma esfera do conhecimento humano ao mesmo tempo tão próxima e tão distante das pessoas, a filosofia.

\subsection{Os Cafés Filosóficos ou o "Café Philo"}

Filosofar é tomar distância em relação ao que se faz e ao que se diz. Assim, é bem mais natural para o filósofo intervir em segundo lugar do que em primeiro. Sua intervenção requer o que já foi dito. E é por isso que ajo de maneira a que aqueles que propõem um tema sejam os primeiros a falar e, por assim dizer, solicito outros defensores. No que concerne a um assunto, há sempre ao menos uma causa a defender, amiúde muitas mais. Tantas quantas são expressas, por conseguinte, por seus defensores. Assim, muitas vezes as dificuldades emergem por si, com os oradores entrando inevitavelmente em conflito uns com os outros. Cabe-me então evidenciar essas oposições, torná-las patentes, colocar a assembléia em sintonia com isso e requerer dela uma solução ou a admissão de que há ali uma contradição irredutível, pelo menos até aquele ponto, ou seja, dentro dos limites do nosso debate. (SAUTET, 2006, p. 43). 
Numa tarde sábado de julho de 1992, o professor e filósofo Sautet (2006) deu uma entrevista na rádio France Inter ${ }^{4}$, durante a habitual revista cultural, sobre a proximidade da data da inauguração de seu consultório na Rue de Sévigné, perto do Café des Phares, Praça da Bastilha, Paris. Sautet (2006) estava prestes a abrir o primeiro consultório na França para atendimento a pessoas angustiadas com os problemas do final do milênio. Em sua fala na rádio, o professor comentou que, em todo domingo de manhã, costumava se encontrar com alguns amigos no Café des Phares para verificar a situação das obras de seu consultório na referida rua. Um grupo de ouvintes concluiu que havia um "filósofo" à sua disposição nas manhãs de domingo para dialogar no café da Praça da Bastilha. Os ouvintes foram até lá, acabaram encontrando o professor e, a partir daí, deu início à discussão. Alguém sugeriu falar sobre as experiências de estados próximos da morte, depois abordaram as questões do Além e da decadência das civilizações e, segundo o professor, o tempo passou muito depressa. Na semana seguinte, alguns retornaram, outros vieram e falaram sobre a arte efêmera. E assim se desenrolou o segundo debate no Café des Phares.

Sautet (2006) não tinha ideia sobre quem eram aquelas pessoas, no entanto tinha uma certeza, não compareciam para se impor, mas para trocar ideias. Segundo o registro de suas lembranças, fazia parte do grupo um jovem casal, uma mulher mais velha secretária de uma empresa de cosméticos, um velho professor, uma advogada de ofício, um poeta, mulheres jovens ou menos jovens, um rapaz baixote e gorducho, músicos que tocavam na noite de Paris e passavam no café para o desjejum, entre outros. De uma semana para outra, o grupo se modificava, pois ninguém tinha a obrigação de aparecer. Porém o impulso inicial havia sido dado e nem o inverno rigoroso fez o debate do Café des Phares entrar em hibernação.

A forma livre e ingênua com que os debates eram conduzidos dava margem a muitas tentações. A primeira delas foi o intelectualismo ou a tendência ao exagero no registro da seriedade. Segundo alguns dos frequentadores, como se tratava de filosofia, um grupo pensava que era importante lidar apenas com conceitos próprios dessa disciplina para não cair na trivialidade da discussão de botequim. Para esse grupo, só se deveria conceder a palavra para aqueles que

4 Radio France Inter - Radio France Internationale, rádio criada em 1975 pelo governo francês, como parte da Radio France. 
dominassem esse tipo de saber. Sautet (2006) foi censurado por vários oradores no sentido de não deixar que qualquer um dissesse o que desejasse. Ele explicou que foi preciso frustrar esse grupo para dar aos outros, os não iniciados, o gosto pela filosofia.

Os assuntos eram escolhidos na hora, sem consulta prévia, e Sautet (2006) afirmou que ele não tinha intenção nem vontade de ele mesmo fazer as proposições. Constantemente Ihe era pedido que falasse de improviso, na hora em que o tema era escolhido. Com o correr do tempo, os temas começaram a entrar em concorrência e foi necessário decidir em função de uns, em detrimento de outros. Esse foi um dos meios de rechaçar a tendência de alguns participantes de "elevar" o nível do debate sem se preocuparem se todos estavam compreendendo ou não. $A$ solução tomada por Sautet (2006) foi a de escolher, dentre os temas, os que menos dessem margem a essa situação. Era comum reivindicar para os intelectuais de visita que se expressassem com palavras do dia a dia, por isso a opção frequente por temas que não fazem parte da esfera filosófica clássica como uma frase banal ou uma expressão corriqueira. Desse embate, surgiu, por exemplo, o tema "A primeira vez".

Para seu "criador", os debates no café foram um teste para a filosofia, uma situação experimental que permitiu saber se a filosofia serve para aquilo que pretende. Segundo ele, a filosofia pretende alçar seus adeptos acima dos preconceitos. Os debates ali travados foram além do desafio pessoal ao qual o filósofo se vê submetido, sua oportunidade de comprovar que sua disciplina é boa e vale a pena seguir seu caminho e é melhor fazer isso a concordar com as opiniões dominantes. Sautet (2006) relembrou:

Domingo, portanto, 13 de dezembro de 1992, Café des Phares, praça da Bastilha, Paris. É meio-dia. Reina na sala um clima estranho. Trinta a quarenta pessoas fazem uma reunião, em vez de estampar a crônica indiferença (às vezes apenas fingida, é verdade) que costumam ter os fregueses uns pelos outros. Qual o assunto? Política, sem dúvida, certo? Ou algum acontecimento, um novo escândalo, um boato? Quem apurasse o ouvido nesse exato momento ouviria uma jovem afirmar que, quando rasga um pedaço de papel, ela o faz sofrer! Será louca? Não parece: é muito calma, bem arrumada e se empenha em explicar-se. Faz uma hora, está na companhia desse grupo, que está refletindo sobre a violência. (SAUTET, 2006, p. 19).

As sessões de domingo no Café des Phares lideradas por Sautet (2006) chegaram a atingir a audiência de 120 ou 150 pessoas, pouco, em termos absolutos, 
se comparadas às missas da Catedral de Notre Dame ${ }^{5}$ ou aos concertos de Bercy ${ }^{6}$. Sautet (2006) ironizou ao lembrar que qualquer ofício religioso ou o menor dos concertos de subúrbio atraem um número mais significante de pessoas do que a filosofia no Café des Phares. Esse fenômeno, então, atraiu a atenção da imprensa, que não hesitou em classificá-lo na categoria das novidades divertidas sem deixar de ser sarcástica com os que sentiam necessidade de fazer parte dele. Algumas das manchetes assim diziam: "Marc Sautet lançou uma nova moda: a da ginástica de cerebelo" ou "Depois do esporte na calçada e do amor na alcova, é chegada a hora da filosofia de balcão" ou ainda, "É o advento da cultura self-service. Sem outra serventia senão a que é ditada por suas próprias questões sobre a vida. Frescura".

A "filosofia de balcão" também gozou de momentos de virtude em relação à imprensa. Muitos jornalistas chegaram até a demonstrar certo entusiasmo por esse fenômeno e contribuíram para que ele continuasse. A reputação do Café des Phares atingiu seu auge quando, após alguns comentários no rádio, um artigo no Télérama ${ }^{7}$ e uma página inteira no Le Nouvel Observateur ${ }^{8}$, ele foi comparado ao Café de Flores, pois, afinal de contas, a tradição da filosofia no bistrô estava aí retomada. Embora essa abordagem não tenha sido unânime, então as manchetes diziam: "A filosofia deixa as esferas etéreas da universidade e desce à rua": boa notícia, existe um lugar onde os "universitários admitem ser contestados por interlocutores que não estudaram filosofia!". Em outro jornal anunciaram: "Paris descobre os tratamentos de Platão", "Aí está, portanto, a aprendizagem da sabedoria de volta à praça pública".

Sautet (2006) viu sua vida pessoal e profissional ser atacada e criticada pela mesma imprensa que em outro momento apreciou em contar a novidade do debate no café. Para a imprensa, os debates no café escondiam uma iniciativa de cunho comercial com estreita ligação à montagem do seu consultório. Os debates dominicais no Café des Phares se prolongaram até o ano de 1998, quando Sautet (2006) adoeceu e faleceu. Os "Cafés Philos", como ficaram conhecidos, se espalharam pelo mundo e em várias cidades francesas. No Brasil, os Cafés Filosóficos tiveram início na cidade do Rio de Janeiro numa iniciativa da Aliança Francesa e, também, na cidade de São Paulo.

5 Catedral de Notre Dame (1163), Praça Parvis, île de la Cité, Paris, França.

6 Concertos de Bercy - Bercy Village, Centro comercial situado no $12^{\circ}$ distrito de Paris instalado em galpões e armazéns antigos e restaurados onde o Palais Omnisports de Pares-Bercy (POPB) se transformou em um local de concertos e eventos.

7 Télérama - Revista semanal francesa de propriedade do jornal Le Monde.

8 Le Nouvel Observateur - Revista semanal francesa fundada em 1950. 
Não há registros na trajetória de Sautet (2006) que fazem a ligação entre os Cafés Filosóficos e os Cafés Científicos. Os registros existentes, porém, conseguiram estabelecer essa relação por si só. Ambos foram criados na França nos anos de 1990. O fim do ciclo dos Cafés Filosóficos, no Café des Phares, em Paris, coincidiu com o início do ciclo dos Cafés Científicos, nas cidades de Lyon e Leeds. O grupo espontâneo de pessoas que se reuniam nas manhãs de domingo para "filosofar" inspirou outro grupo que deu início, nos mesmos moldes, ao surgimento dos Cafés Científicos.

\subsection{Os Cafés Científicos — da filosofia de balcão à ciência de balcão}

A história dos Cafés Científicos não possui um relato descrito na pessoa de um cientista, um pesquisador ou algo parecido. As informações foram colhidas em sites da internet utilizando como procedimento de busca as palavras "Café Scientifique" e "Café Scientifique Lyon". Após a leitura do material disponível nos sites encontrados, foram inseridas nas buscas as palavras "Science in the Pub" e, por último, o termo em português, "Café Científico". As buscas encontraram registros da história desses eventos ao redor do mundo e como, em diferentes países, um fenômeno de comunicação pública da ciência tomou corpo nos últimos anos através de projetos como esse.

Os Cafés Científicos são locais onde, segundo a descrição disponível em seu site referencial, pelo preço de uma xícara de café ou um copo de vinho, qualquer pessoa pode comparecer para explorar as últimas ideias da ciência e da tecnologia. Os encontros acontecem em cafés, bares, restaurantes e teatros, sempre fora do tradicional contexto acadêmico.

Esses "Cafés" são um fórum para o debate dos assuntos da ciência, e não uma vitrine para a ciência. As pessoas envolvidas estão comprometidas com a promoção do engajamento público com a ciência e de fazer dela algo explicável.

O site do British Council trouxe uma ideia mais ampliada a respeito desses espaços. Os Cafés Científicos propõem ambientes descontraídos, nos quais, é possível conversar sobre as mais recentes questões instigantes da ciência. Não é preciso ser um cientista ou um estudante da ciência para fazer parte porque são eventos que discutem sobre a ciência e a vida e de que forma essa relação molda o mundo em que vivemos. Por causa disso, todos são bem-vindos. 
A criação de um ambiente informal e amigável é a questão central dos Cafés Científicos. Esse fato contribui para o estabelecimento de um debate aberto e interessante no qual as pessoas podem oferecer suas opiniões, fazer perguntas ou simplesmente ouvir. A rede informal que surgiu em torno desse evento é composta dos mais diferentes indivíduos, grupos e organizações que planejam os "Cafés" em todo o mundo.

Nas informações divulgadas nos sites, constam que o primeiro Café Científico aconteceu em Lyon, na França, em 1997. O "Comunicador da Ciência" Duncan Dallas desenvolveu esse conceito no Reino Unido e organizou na cidade de Leeds, em 1998, o primeiro "Café" desse país. O conceito chegou às escolas com o projeto Junior Café Scientifique, onde os estudantes são estimulados a organizarem eles próprios os cafés.

Os tópicos para discussão incluíram a Acquired Immunodeficiency Syndrome (AIDS), o Big Bang, a biodiversidade, o câncer, as mudanças climáticas, o Darwinismo, a evolução, os organismos geneticamente modificados, a nanotecnologia, entre outros.

Atualmente, de acordo com o site do British Council, em torno de 40 países são realizadas reuniões regulares para que o público possa escutar cientistas ou trabalhadores da ciência conversar sobre seu trabalho e discutir com uma audiência diversificada. Segundo as informações contidas no site, o British Council, além de dar suporte para que essas reuniões aconteçam, utiliza-se da tecnologia de videoconferências para unir os participantes ao redor do mundo, o que gera uma grande miscelânea de ideias culturais para a discussão. Os eventos não contam somente com a presença do palestrante, mas com a mediação de um facilitador vindo do Reino Unido. A função do facilitador é vital para que a discussão possa fluir. $A$ intenção é a de que os grupos tenham uma conversação inclusiva que não se limite a uma situação de perguntas e respostas entre a audiência e o palestrante. Independente da atuação do British Council, cerca de 180 países possuem atividades de comunicação pública da ciência no formato dos "Cafés".

Para a execução de um evento como esse, é necessária, segundo as informações do site, uma lista de tópicos básicos, porém, imprescindíveis, que incluem um organizador dedicado ou uma equipe, um ambiente não acadêmico, um palestrante inspirador e um assunto, um facilitador e um público. Algumas experiências realizadas pelo British Council no Brasil estão relacionadas no Quadro 1: 
Quadro 1 - Cafés Científicos do British Council com participação do Brasil

\begin{tabular}{|c|c|c|}
\hline Tema & Data & Local \\
\hline $\begin{array}{l}\text { Darwin Agora - Desmistificando as } \\
\text { Células Tronco }\end{array}$ & 16/fev/2009 & São Paulo e Bogotá \\
\hline $\begin{array}{l}\text { Darwin Agora - Os humanos são } \\
\text { especiais? }\end{array}$ & 23/out/2008 & $\begin{array}{l}\text { Recife, Argentina, Chile e } \\
\text { Reino Unido }\end{array}$ \\
\hline $\begin{array}{l}\text { Darwin Agora - Os humanos são } \\
\text { especiais? }\end{array}$ & 12/mar/2009 & $\begin{array}{l}\text { Brasília, Recife e Reino } \\
\text { Unido }\end{array}$ \\
\hline Energia limpa para o desenvolvimento & 25/fev/2008 & $\begin{array}{l}\text { Brasília, Rio de Janeiro e } \\
\text { Reino Unido }\end{array}$ \\
\hline Mudanças Climáticas e Energia & $29 / \mathrm{fev} / 2008$ & Edimburgo, Recife e Moscou \\
\hline Biocombustíveis & 28/nov/2007 & Rio de Janeiro e Reino Unido \\
\hline $\begin{array}{l}\text { Mudanças Climáticas } \\
\text { Humanos }\end{array}$ & $30 /$ out/2007 & $\begin{array}{l}\text { Recife, Edimburgo e Nova } \\
\text { Delhi }\end{array}$ \\
\hline Mudanças Climáticas e Escolas & 04/out/2007 & Recife, São Paulo e Londres \\
\hline $\begin{array}{l}\text { Mudanças Climáticas e } \\
\text { Comunitárias }\end{array}$ & $20 /$ set/2007 & Recife e Reino Unido \\
\hline $\begin{array}{l}\text { Créditos de Carbono: há algum crédito } \\
\text { nisso? }\end{array}$ & 30/ago/2007 & $\begin{array}{l}\text { Recife, Rio de Janeiro e } \\
\text { Manchester }\end{array}$ \\
\hline Mudanças Climáticas & 23/mar/2007 & Recife, São Paulo e Londres \\
\hline $\begin{array}{l}\text { Energia renovável e a indústria da } \\
\text { construção civil }\end{array}$ & 05/dez/2006 & Curitiba \\
\hline Tendências no Ecodesign & 07/nov/2006 & Curitiba \\
\hline Bar científico: a química da atração & 14/ago/2006 & Curitiba \\
\hline $\begin{array}{l}\text { Mudanças Climáticas: nós podemos } \\
\text { mudar isso }\end{array}$ & $\mathrm{ov} / 2005$ & $\begin{array}{l}\text { Londres, Brasília e São } \\
\text { Paulo }\end{array}$ \\
\hline Mudanças Climáticas & 17/nov/2005 & $\begin{array}{l}\text { Londres, Curitiba e Rio de } \\
\text { Janeiro }\end{array}$ \\
\hline $\begin{array}{l}\text { Terapias com células tronco: costurar } \\
\text { tecidos é um pesadelo ou uma } \\
\text { panaceia? }\end{array}$ & 29/mar/2005 & $\begin{array}{l}\text { Londres, Rio de Janeiro e } \\
\text { Recife }\end{array}$ \\
\hline
\end{tabular}

Fonte: Elaborado pela autora.

Os eventos acima registrados (QUADRO 1) possuem seções, no site do British Council, que apresentam relatos dos eventos, os cientistas e os comunicadores que neles participaram. A forma de apresentar esses cientistas e comunicadores foi um fato que chamou a atenção. $O$ exemplo a seguir ilustrou a situação. No evento realizado no Brasil e registrado no site, em fevereiro de 2009, entre as cidades de São Paulo, no Brasil, e Bogotá, na Colômbia, cujo título foi "Darwin Now", assim foram apresentados os cientistas ingleses: 
technology to Brazil to exchange ideas with their peers and with policy makers and members of the government about hot issues in science and technology and on the way each country is dealing with the political and ethical aspects generated by some of them.

Baroness Susan Greenfield

Baroness Susan Greenfield, the renowned British neuroscientist, will visit Brazil in December. Learn more about the brain in one of her lectures.

\section{Sir David King}

Sir David King, the UK's Chief Government Science Adviser, visited Brazil in June 2005. As the UK Government's top adviser on climate change he met with Brazilian experts and policymakers in the run-up to the G8 meeting in Scotland. During his visit he also gave numerous media interviews and gave a public lecture at which he outlined the key challenges facing the planet. During his visit Sir David King launched our ZeroCarbonCity campaign in Brazil with the opening of the exhibition NorthSouthEastWest.

Para o mesmo evento, assim foram apresentados os "comunicadores" da ciência:

Scientists and science communicators are key to the successful engagement of ordinary individuals with the scientific advances that impact on our everyday lives. We help to bring eminent figures from the UK to discuss with their Brazilian peers and present their ideas to the wider public through events, web and media.

Frank Burnett 2009

The International Director of Cheltenham Festivals and also Emeritus Professor of Science Communication in England was invited to deliver a presentation and take part in round tables during the celebrations of the $10^{\text {th }}$ anniversary of the Museum of Life in Rio de Janeiro in partnership with the ABCMC (Brazilian Association of Centres and Science Museums).

Quentin Cooper 2007

Described by The Times as "the world's most enthusiastic man", Quentin Cooper presented in the " $5^{\circ}$ Congresso Brasileiro de Unidades de Conservação' in Foz do Iguaçu [...] Learn more about this visit.

Os renomados cientistas e especialistas da ciência e da tecnologia foram apresentados pelos títulos de "Baronesa" e "Sir". Os comunicadores da ciência foram incumbidos da responsabilidade de promover com sucesso o engajamento dos cidadãos em relação aos avanços da ciência e aos impactos promovidos por ela em suas vidas diárias, através de suas habilidades de falar para suas audiências com grande entusiasmo.

Os registros apresentaram informações dos "Cafés" em diversos países do mundo. As reações do público, as interações com os palestrantes e os facilitadores não estão disponíveis, fato que permitiu conhecimento parcial da relação entre o público e os acontecimentos da ciência.

O site da Associação Brasileira dos Centros e Museus de Ciência (ABCMC) 
apresentou o registro de alguns desses eventos tanto aqui quanto no exterior. Nesse mesmo site, apareceram registros de eventos correlatos aos "Cafés" como os "Science in the Pub" ou "Ciência no Buteco".

Esse projeto, "Ciência no Buteco", de nome sugestivo e ideias semelhantes, surgiu na Austrália na mesma época dos "Cafés" franceses e ingleses em 1998. Robyn Stutchbury, cocoordenador desse projeto, questiona como é possível quebrar a torre de marfim da ciência e deixar que o público faça parte desse processo. Os tópicos eram escolhidos pelo voto popular e os palestrantes eram selecionados pelas suas capacidades de aliar as habilidades de comunicação com as de beber algumas canecas de cerveja. A intenção de criar um ambiente de debate descontraído que não iniba a participação do público é bem mais marcante nos eventos australianos. Os temas votados pelo público foram praticamente os mesmos já mencionados. A forma de abordá-los chamou a atenção, por exemplo, "God and the Big Bang" (Deus e o Big Bang) ou "Dark Matter — the stuff that holds the Universe together" (Matéria Escura o material que mantém o Universo em conjunto) ou ainda, "What more does the Universe have to do?' (O que mais o Universo precisa fazer?). A interação entre cientistas, ciência e público é a principal prioridade para seus organizadores. Os registros desses eventos encontrados foram até 2004.

Com as mesmas propostas dos "Cafés" europeus e dos "Pubs" australianos, o Oregon Museum of Science and Industry, Portland, Estados Unidos, oferece para seus visitantes e demais interessados o espaço "Science Pub", onde ciência, cientistas, pesquisadores e público podem se reunir em torno de uma boa conversa e de boa comida.

Em outubro de 2009, o "Q2Cfestival" (Quantum to Cosmos Festival), em Waterloo, Ontário, Canadá, desenvolveu, através da revista CoSMOS Magazine, outro projeto "Science in the Pub" no formato de um programa de auditório com uma plateia animada. Foram realizadas seis seções cujas gravações estão disponíveis no site do festival. Os títulos sugestivos continuaram ("So We're All Gonna be Robots Now?'), anunciados mediante palmas e gritos da plateia (Ladies and gentleman, goodnight, welcome to Science in the Pub...).

A busca pelos "Cafés" ou por situações de comunicação pública da ciência com o mesmo formato, nos organismos internacionais, permitiu somente o relato dos eventos. Resultados semelhantes aconteceram quando houve busca feita com o uso do termo em português, porém, acompanhado de novo detalhe. A procura com as 
palavras "Café Científico" abrangeu não somente a ocorrência dos "Cafés" no Brasil, e em Portugal, por motivos óbvios, mas atingiu os países de língua espanhola, como a Espanha, principalmente.

No Brasil, existem registros de eventos de Cafés Científicos nas cidades de São Paulo, Rio de Janeiro, Brasília, Porto Alegre e, com atuação significante, em Salvador, no estado da Bahia. Os "Cafés" em São Paulo e no Rio de Janeiro têm estreita relação com museus de ciências de ambas as cidades. O Museu da Vida, juntamente com a Fiocruz, promoveu o primeiro "Chopp Científico" em setembro de 2002. Uma equipe de cerca de 20 profissionais, entre físicos, biólogos, químicos, poetas, jornalistas, atores, músicos, e uma plateia com lotação esgotada, em torno de 130 pessoas, debateram sobre a história da cerveja ao som de muita música, leituras de textos e poemas.

Em Porto Alegre, no Rio Grande do Sul, os "Cafés" fazem parte de um ciclo de palestras, filmes e debates promovidos pelo Instituto de Física da Universidade Federal do Rio Grande do Sul (UFRGS) com o apoio da produtora "E o Vídeo Levou - Centro de Entretenimento". A programação divulgada no site para o ano de 2010 foi até o mês de dezembro.

Em Brasília, eles fazem parte de uma parceria entre a Embaixada da França, a Aliança Francesa e o Institute de Recherce pour Le Développment (Instituto de Pesquisa para o Desenvolvimento - IRD) e acontecem, geralmente, no terraço do Restaurante "Daniel Briand" no intervalo de dois a três meses. O programa consta de três palestras, seguidas de debate e lanche em um ambiente aconchegante e informal. Os pesquisadores do IRD e seus parceiros apresentam em torno de três palestras de dez minutos cada, que "alimentam" um debate entre todos os participantes. O detalhe final fica por conta do lanche, delícias da culinária francesa, oferecido pela Embaixada da França. O lanche não somente encerra a programação do dia como possibilita o prolongamento das discussões e dos encontros.

Em Salvador, os "Cafés" são promovidos pelo Programa de Pós-Graduação em Ensino, Filosofia e História das Ciências da Universidade Federal da Bahia (UFBA/UEFS) e pela Livraria Multicampi (LDM). Foi possível perceber uma atuação significativa desses eventos pelo elevado número de ocorrências registradas pela busca. Os temas debatidos levam em conta também problemas locais e regionais como a exploração do minério - "Minério: base material da trajetória humana" ou os parasitas e as doenças causados por eles no homem - "Os Parasitas e o Homem". 
O Café Científico de 22 de março de 2010 contou com o lançamento de um jogo eletrônico educacional chamado "Calangos". O jogo simula o ambiente das dunas do Médio São Francisco, no estado da Bahia, investigada por pesquisadores brasileiros, inclusive da UFBA, e teve como objetivo ensinar, por meio dele, conteúdos sobre ecologia e evolução.

Para finalizar o percurso da história dos "Cafés", tem-se a classificação das maneiras de organização dos Cafés Científicos segundo Olvera e Chávez (2007), que levaram em consideração experiências anteriores desenvolvidas nos países França, Inglaterra e Dinamarca. $O$ modelo francês, que convida dois debatedores com posturas opostas em relação a um tema. $O$ modelo britânico em que um convidado expõe um tema durante vinte minutos sem aparatos audiovisuais para, depois de um breve descanso, iniciar o diálogo com o público assistente. E o modelo dinamarquês, no qual o diálogo interdisciplinar é promovido entre as ciências humanas e as ciências naturais, a arte ou a cultura, a partir de um tema.

Os registros do percurso dos Cafés Científicos trouxeram a dimensão da territorialidade conquistada em tão pouco tempo de funcionamento e do dinamismo dos sujeitos envolvidos em criar situações inusitadas para discussão dos assuntos da ciência e da tecnologia. Porém, praticamente a totalidade das informações aqui relatadas foi obtida através de uma pesquisa documental nos sites dos "Cafés" disponíveis na internet. Essa pesquisa evidenciou dados sobre os "Cafés" que puderam facilmente ser relacionados como: os países, os ambientes, as datas, os objetivos, alguns nomes de cientistas e as programações dos eventos. Os objetivos foram unânimes ao proporem, quase em uníssono, ambientes, não importa em qual país, externos ao contexto acadêmico para discutir com os sujeitos de fora do mundo da ciência, sobre ciência.

Poucos foram os registros impressos encontrados. Essa constatação não descartou a continuidade da busca por esses registros. A revisão aqui apresentada se baseou, na maior parte, nas informações obtidas nos sites encontrados - o que são os "Cafés", seus ambientes, seus objetivos, datas e horários, países e cidades, fotografias e logotipos. Portanto, boa parte do material da pesquisa documental se fundamentou a respeito da pertinência do material disponível e passível de pesquisa sobre "comunicação da ciência" e, em especial, sobre a "comunicação da ciência" nos ambientes dos Cafés Científicos. 


\section{OS TRÊS CONTEXTOS DE COLETA DE DADOS}

Os três contextos de coleta de dados, a seguir, fazem de parte de um processo marcado pela relação entre procedimentos de pesquisa e procedimentos de produção.

Os dois primeiros contextos trouxeram a oportunidade de vivenciar duas experiências de Café Científico exatamente na fase em que se pesquisava e se estudava sobre eles. Observar o funcionamento desses diferentes eventos foi fundamental para apurar o olhar ao colocar em prática o terceiro contexto, objeto de pesquisa desta tese, o "Barômetro - Ciência, café e debate".

Outra contribuição desses dois contextos foi a de exercitar a relação entre teoria e prática ao analisá-los segundo os aportes teóricos principais - o conceito de Dispositivo Pedagógico de Bernstein (1990) e os Modelos de Comunicação Pública da Ciência de Lewestein (2003). Estudar as concepções propostas por esses autores e os acontecimentos no interior desses contextos ajudou a refinar 0 processo de entendimento de suas proposições e a olhar para o terceiro contexto de forma mais crítica.

As formas através das quais a sociedade se organiza para exercer a atividade de comunicação são estruturas dinâmicas que podem, muitas vezes, seguir padrões determinados, mas que também podem se abrir para a inovação. Os três contextos percorreram caminhos diversos e demonstraram que comunicar sobre qualquer assunto, mas principalmente sobre ciência, pode ser uma experiência flexível, divertida e participativa.

\subsection{Primeiro contexto de coleta de dados: Um Café Científico Júnior sobre aquecimento global}

A primeira situação de coleta de dados aconteceu em um Café Científico promovido pelo projeto "Memória e História de Técnicas e Tecnologias contadas nos espaços museográficos do CEFET-MG, em Cafés de Ciência e Tecnologia". Esse projeto foi desenvolvido por uma equipe de pesquisadores do CEFET-MG em parceria com laboratório Interactions, Corpus, Apprentissages, Représentations (ICAR), da Université Lyon 2, Lyon, França. Foram realizados ao todo três "Cafés", um em setembro de 2009 e dois nos meses de agosto e setembro de 2010. Uma de suas ações e metas foi a de estabelecer parcerias com escolas públicas do entorno 
dessa instituição de forma que os eventos dos "Cafés" pudessem acontecer também nessas escolas. A escola selecionada foi a Escola Estadual Maurício Murgel (EEMM), onde os "Cafés" aconteceram em seu auditório. Os temas, o primeiro proposto e os dois seguintes escolhidos pelos alunos dessa escola, foram, na ordem: NANOTECNOLOGIA, AQUECIMENTO GLOBAL e REDES SOCIAIS.

O acontecimento de um "Café" inserido em um espaço escolar atribuiu ao evento uma característica particular. Ainda que os objetivos fossem os mesmos dos "Cafés" originais, eles passam a assumir a denominação de "Junior Café Scientifique" ou Café Científico Júnior. O site do British Council introduziu essa denominação (para os "Cafés" desenvolvidos por estudantes ou direcionados para eles) e se pôde encontrá-la também no projeto "Débats, Diversité et Developpement Durable: Le café scientifique Junior dans l'enseignement DD dans diverses cultures" do laboratório ICAR. Na modalidade "Junior", os "Cafés" se constituem como eventos que passam por todo um processo de preparação junto aos estudantes e aos respectivos debatedores, o que permitiu uma coleta de dados mais sistematizada. O Café Científico aqui descrito seguiu essas características.

A seguir, a descrição do segundo Café - Aquecimento Global:

Duas reuniões foram realizadas com a equipe do projeto do CEFET-MG e a equipe da EEMM, composta pelo vice-diretor, dois professores e um grupo de dez alunos do ensino médio dessa escola. Os alunos que foram convidados a participar das reuniões foram escolhidos pelo vice-diretor. Seu critério de escolha se deu por serem alunos envolvidos em projetos da escola financiados pela iniciativa privada. Dentre os projetos estão a construção de um site, uma rádio, uma revista eletrônica e projetos de inclusão para alunos cegos e surdos. Um dos alunos presentes era portador de deficiência visual. Duas alunas eram bolsistas do projeto do Café Científico. Esperou-se que o engajamento inicial desse grupo de alunos tivesse repercutido no engajamento do restante dos alunos na participação do evento. Uma condição que restringiu maior participação dos mesmos foi a capacidade do auditório da escola que comportava duzentas pessoas. Ficou prevista pelo menos mais uma reunião na escola antes da data do "Café". Dois debatedores foram convidados, ambos professores do CEFET-MG.

Reuniões com os debatedores foram também agendadas para maiores esclarecimentos sobre o evento e algumas questões foram levantadas, como: tempo de fala (trinta minutos para cada um), abordagem do tema, utilização de recursos 
multimídia, local, data, hora, formato do evento, linguagem, entre outros. A equipe do projeto Ihes solicitou a elaboração de perguntas simples e diretas, do tipo múltipla escolha, cujas respostas pudessem ser contabilizadas durante a realização do evento. $O$ resultado foi apurado na hora e poderia influenciar, inclusive, a condução do que foi planejado inicialmente. A equipe do projeto teve a intenção de, através dessas perguntas, provocar maior interação entre os debatedores e os alunos.

Desde o momento em que foram convidados, os debatedores assumiram posições diferenciadas sobre o tema e fizeram suas propostas de palestra. A equipe do CEFET-MG acatou prontamente essas decisões. Outra resolução foi a de retirar a mesa, no palco do auditório, mobiliário geralmente utilizado em apresentações nesses espaços. Essa decisão teve como principal objetivo procurar aproximar fisicamente debatedores e estudantes.

\subsection{Segundo contexto de coleta de dados: 0 "Café des Techniques", Paris, França}

O segundo contexto de coleta de dados aconteceu em uma visita ao Conservatoire National des Arts et Métiers (CNAM - o museu de artes e ofícios da capital francesa), na cidade de Paris, França. Esse evento ocorreu no dia 17 de fevereiro de 2011, no restaurante desse museu. De acordo com as informações fornecidas pela coordenadora de eventos da instituição, a bióloga Amélie Zanetti, o Café dês Techniques é um projeto de Café Científico que teve início no ano de 2002 nesse espaço do museu. Ao longo desse tempo, aconteceu a formação de público que contava, até então, com uma média de oitenta participantes por mês. Os "Cafés" acontecem sempre na terceira quinta-feira do mês, no horário de $18 \mathrm{~h} 30$ às $20 \mathrm{~h}$. Especialmente nesse dia, estavam presentes em torno de 120 pessoas e isso se deveu, para a equipe do museu, ao tema debatido naquela noite (Le droit à oubli sur Internet est-il possible?)

No convite impresso, direcionado para o público, o evento foi caracterizado como um "café-debate sobre a atualidade científica e técnica, um lugar de diálogo entre pesquisadores, industriais, profissionais e cidadãos" (tradução da autora). Mesmo com essa caracterização, os funcionários do museu se referiram ao evento como a "conference", ou seja, a conferência. Para essa noite de debate, foram convidados um sociólogo, um advogado, um mestre de conferências da Université de Versailles St-Quentin e um mediador a quem a coordenadora se referiu como um 
jornalista científico, incumbido da "animação" do encontro. A equipe organizadora dos "Cafés" nesse museu contava, na época, com três jornalistas científicos que se revezavam de três em três meses.

Como o número de participantes superou a capacidade do espaço físico do restaurante, não houve como manter o lay out tradicional de mesas e cadeiras. Os assentos foram dispostos em fila como se o local fosse um auditório improvisado. $O$ público geralmente não tem visão direta dos debatedores, mesmo nos dias de menor audiência, pois existe um aquário gigante no meio do restaurante. Dessa maneira, um telão e um aparelho de TV LCD foram instalados em dois diferentes pontos para que todos pudessem acompanhar 0 debate. Os debatedores permaneceram sentados o tempo todo enquanto o mediador fez as apresentações e circulou entre a plateia em busca de candidatos a perguntas. Foi o mediador quem criou a dinâmica do debate e parecia ter familiaridade com o assunto. Cerca de quinze perguntas foram feitas, dois participantes fizeram perguntas longas e ocuparam muito tempo do debate com suas colocações. Segundo a coordenadora, quando isso acontece não é bom porque atrapalha a participação dos outros. O mediador tem de contornar a situação e fazer com que a dinâmica do debate retorne. O sociólogo e o advogado responderam a quatro perguntas cada um e o mestre de conferências respondeu a sete perguntas.

A coordenadora enfatizou algumas questões. A primeira delas foi a necessidade de convidar debatedores de diferentes áreas que não somente às relacionadas à ciência propriamente dita; a segunda foi a questão do tempo que, de acordo com sua experiência, não pode ultrapassar os noventa minutos; a terceira foi a necessidade da equipe organizadora de manter contato constante com o público que frequenta os "Cafés" através de e-mails e do material de divulgação das demais atividades do museu e, por último, a participação do mediador, no caso deles o jornalista científico, "animador" que delineia a dinâmica dos debates.

O evento assistido se desenrolou em um ambiente de austeridade que, embora tenha sido concebido dentro das diretrizes de informalidade que regem os Cafés Científicos, em muito se distanciou delas. O público, em sua maioria acima dos quarenta anos, alguns jovens estavam presentes, pouco se manifestou e não fez outra coisa a não ser prestar atenção. Registros de áudio e de imagens não foram permitidos por parte da coordenadora. Ao final do evento, apenas uma estudante de design se deixou fotografar e deu um pequeno depoimento. 


\subsection{Terceiro contexto de coleta de dados - o contexto desta pesquisa}

\subsubsection{O projeto "Barômetro - Ciência, Café e Debate" - a construção de um dispositivo pedagógico}

O terceiro contexto, ou o Projeto "Barômetro - Ciência, café e debate", foi apresentado precedido da concepção de Bernstein (1990) sobre Dispositivo Pedagógico. Esse contexto mereceu atenção especial, uma vez que ele foi cuidadosamente concebido para esta pesquisa. Daí o motivo para se discutir, a partir dele, dispositivos pedagógicos e o que ocorre nas interações que surgem em seus funcionamentos internos.

Tanto os procedimentos de produção quanto os procedimentos de pesquisa se serviram das colocações de Bernstein (1990) para a organização e o funcionamento desse contexto. Entender sua organização interna foi fundamental para inserir nele a inovação, perceber suas nuances e as reações das pessoas que por ele transitaram.

O ponto de partida de Bernstein (1990) para explicar sua concepção de dispositivo pedagógico se referiu às diferentes perspectivas que geralmente são adotadas em relação à forma de comunicação extremamente especializada que acontece nas escolas ou nas universidades. A primeira coisa que é feita é a ignorância de seus fundamentos, de modo que as pessoas falam dessa forma especializada de comunicação, que ele chamou de "discurso pedagógico", como se esse discurso sempre fora um dispositivo de transmissão de alguma outra coisa. Desse modo, o discurso pedagógico nas escolas é transmissor das relações de poder que acontecem fora da escola, de modelos de relações entre o dominante e o dominado.

Bernstein (1990) relatou que essas formas de análise chamaram sua atenção porque era como se o transmissor em si não tivesse mensagem, como se 0 dispositivo de transmissão fosse cego e fosse somente um meio através do qual os outros meios pudessem falar, embora o transmissor em si não tivesse voz. Quanto mais se lê sobre educação, sempre se lerá acerca do que é transmitido, da educação como um instrumento de aquisição ineficiente ou se lerá sobre um instrumento de transmissão como um meio pelo qual se pode transmitir um "pacote" portador de uma didática. É como se o transmissor em si carecesse de uma lógica interna, de uma estrutura interna. E esse é o foco da análise de Bernstein (1990), a lógica interna do discurso pedagógico. 
O autor se perguntou se esse discurso possui uma voz. Se sim, por que nunca a escutamos? Qual seria sua estrutura? Sua ideologia corresponde somente ao que é transmitido? Ele propôs três regras que constituem o que ele denominou de dispositivo pedagógico, fundamental para a produção, reprodução e transformação da cultura. Esse dispositivo possui uma estrutura interna que consiste de três conjuntos de regras - distributivas, de recontextualização e avaliativas que se encontram em uma relação hierárquica umas sobre as outras. Assim, a regra distributiva é a primeira, da qual se derivam a segunda e a terceira. Essas três regras constituem a lógica interna de qualquer dispositivo pedagógico, seja ele formal ou informal.

A regra distributiva, literalmente, distribui diferentes formas de consciência para diferentes grupos. A segunda regra, de recontextualização, regula a constituição de um discurso pedagógico específico e a regra avaliativa constitui a prática pedagógica. A primeira regra distribui a consciência para diferentes grupos, a segunda, o discurso pedagógico e a terceira, a prática. Segundo Bernstein (1990), essa é a lógica interna de qualquer dispositivo pedagógico. Até aqui, disse o autor, pode-se afirmar que o dispositivo pedagógico é o meio através do qual o poder pode ser relacionado com o conhecimento e o conhecimento com a consciência.

Basicamente, as regras distributivas especializam o impensado para certos grupos e o pensado para outros. Em outras palavras, essas regras constituem a classificação entre o sagrado e o profano e distribuem as possibilidades do sagrado a um grupo profano e do profano a outro. Todas as sociedades possuem pelo menos dois tipos básicos de conhecimento: o esotérico e o mundano. $O$ conhecimento do outro e a alteridade do conhecimento ou de como é o mundo possível contra a possibilidade do impossível. O que é impensável em determinado momento do tempo é pensável em outro, de modo que, aquilo que é impensável e pensável é uma questão histórica. Em sociedades analfabetas de pequena escala, por exemplo, com uma divisão simples do trabalho, havia uma divisão entre o pensável e a prática de seu manejo e o impensável. Ambas possuem sistemas de transmissão diferentes. A prática e o manejo do impensável estão constituídos pelo sistema religioso, seus agentes e suas práticas. O pensável possui outro sistema de transmissão e corresponde àquilo que é reproduzido, que é comunicado pelos grupos de diferentes faixas etárias. Na atualidade, os controles sobre o impensável são essenciais, mas não totalmente, e direta ou indiretamente, desenvolvidos nas 
esferas superiores do sistema educacional. Esse não é o único lugar, mas é um espaço legítimo para essa atividade.

As sociedades compartilham um tipo particular de abstração que vincula o material com o imaterial e que, ao relacioná-los, relaciona um mundo com outro. É uma forma de abstração que permite a criação de uma relação entre o local e o transcendente, que insere um mundo no outro, que une o conhecido com uma modalidade de conhecido, que integra o possível com o impensável. Se essa abstração insere o local e o transcendental, o material e o imaterial, então deve haver uma relação indireta entre os significados que suscita essa abstração e qualquer contexto local. Essa abstração é muito interessante porque gera uma brecha, um espaço crucial para possibilidades alternativas, de algo diferente do existente na prática cotidiana, algo que Bernstein (1990) chamou de abertura discursiva. A abertura discursiva é um lugar para o impensável, para o impossível. Mas quem tem acesso a esse lugar, posto que aí é o lugar de encontro da coerência e da incoerência, da ordem e da desordem, de como é e como pode ser, é o lugar fundamental para o pensamento. Nem todos têm acesso a essa abertura e as regras distributivas regulam aqueles que têm acesso a esse lugar. Na medida em que isso ocorre, a distribuição do poder obtém certa especialização da consciência daqueles que têm acesso a esse lugar, mas aqueles que possuem acesso a esse lugar também levam a responsabilidade de limitar sua possibilidade.

Se as regras distributivas marcam e distribuem quem pode transmitir o que a quem e sob quais condições, ao fazê-lo, sentem os limites externos e internos do próprio discurso pedagógico. O autor sugeriu que o discurso pedagógico são as regras de comunicação altamente especializadas, através das quais os sujeitos pedagógicos são seletivamente criados. O discurso pedagógico é também um discurso de inserção e a pergunta é: Que discurso se encontra inserido em qual discurso? Novamente ele sugeriu que o discurso pedagógico sempre insere um discurso instrucional em um discurso regulamentar, de forma que o discurso dominante sempre será o discurso regulamentar.

Por discurso instrucional, o autor entendeu como o discurso que cria competências ou habilidades especializadas. Isso pode significar desde o treinamento de uma criança para controlar o esfíncter até a transmissão dos conteúdos da física e da química. Tudo isso é discurso instrucional. O discurso de instrução cria as habilidades que devem ser adquiridas e as relações entre si. 0 
discurso regulamentar é outra coisa. Se for decidido que o discurso instrucional cria a ordem discursiva, o discurso regulamentar cria a ordem social e contém regras que constituem essa ordem, a relação e a identidade. Qualquer discurso pedagógico é a inserção de um no outro, de modo que, na realidade, há somente um texto. Os dois textos mencionados anteriormente para o discurso pedagógico são, na realidade, um só - o que cria as habilidades da pessoa e acaba por moralizá-la, controlá-la e discipliná-la. O primeiro se insere no segundo, o regulamentar domina o instrucional.

Para Bernstein (1990), esse ponto é extremamente interessante porque, primeiro, o discurso pedagógico não pode ser identificado com nenhum dos discursos que transmite. As regras que constituem o discurso pedagógico são diferentes das regras que constituem qualquer coisa que transmitem. Por exemplo, as regras que constituem a física são diferentes das regras que constituem 0 discurso pedagógico da física, ou seja, a pedagogia da física não é física. Segundo, o discurso pedagógico é carente de um discurso específico, não possui um discurso próprio. O que ele possui então? Qual é sua gramática? A física tem sua gramática, a química tem sua gramática, mas aquela coisa que de algum modo controla o todo não se manifesta em um discurso próprio. Bernstein (1990) quis sugerir com isso que o discurso pedagógico é um princípio para apropriar-se de outros discursos e para colocá-los em uma relação especial, uns em respeito aos outros para sua transmissão e aquisição seletiva. O discurso pedagógico é um princípio para a circulação de outros discursos e isso, na verdade, é um princípio de recontextualização. O princípio de recontextualização move um discurso a partir do seu local de prática, desloca-o e o modifica de acordo com seus próprios princípios de seleção, reordenamento e reenfoque. Nesse processo de circulação, o discurso original se vê transformado, cria-se um discurso imaginário que mantém pouca relação com o discurso real, de modo que o discurso pedagógico necessariamente cria sujeitos imaginários através de um princípio de recontextualização. Uma criança que pratica trabalhos manuais em madeira não pratica marcenaria, está realizando um trabalho pedagógico. Algo acontece com o discurso original no processo de sua transformação seletiva. Se isso está correto, na opinião do autor, deveria ser estudar o princípio de recontextualização e o campo de recontextualização que cria as posições dentre desse campo.

Assim, as regras distributivas controlam as possibilidades do impensável e quem pode pensá-lo. As regras de recontextualização constroem o discurso 
pedagógico e o modo como o discurso instrucional se insere no discurso regulamentar. Para Bernstein (1990), está claro que o discurso regulamentar é o discurso dominante, ou seja, não há instrução sem ordem.

Da mesma forma que a recontextualização cria o discurso pedagógico, a avaliação cria a prática pedagógica. O princípio recontextualizador cria o discurso pedagógico que pode ser aplicado na sala de aula, em determinado momento da atividade, em um currículo, no hospital. Quer dizer, a unidade depende inteiramente do que se vai examinar. A prática pedagógica constrói o texto que será transmitido e insere esse texto no tempo e no espaço. Ao aprofundar um pouco mais, pode-se dizer que a prática pedagógica produz um texto especializado e coloca esse texto especializado em relação com um tempo especializado e com um espaço especializado.

A primeira transformação decorrente disso é a transformação do tempo em idade. Toda prática pedagógica insere o adquirente no tempo de acordo com algum princípio de idade. Essa idade pode ser refinadamente diferenciada ou diferenciada de modo simples. Diferentes sociedades criam separações diferenciadas. $O$ texto é transformado em conteúdo e o conteúdo guarda uma relação com a idade.

$\mathrm{Na}$ segunda transformação, a idade é transformada em soma, o contexto é transformado em transmissão e essa, por sua vez, é transformada em avaliação. Desta maneira, têm-se, no primeiro nível, tempo, texto e espaço, no segundo, idade, conteúdo e contexto e, no terceiro, aquisição, transmissão e avaliação. Nesse ponto, a avaliação adquiriu tacitamente a totalidade.

Bernstein (1990) concluiu que chegou a hora de resumir os ordenamentos do dispositivo pedagógico como uma gramática que regula as relações internas distribuídas em três níveis. O grau de determinação, isto é, os limites externos e as possibilidades internas de cada nível se relacionam com o contexto histórico e ideológico do dispositivo. Para ele, por mais complicado que possa parecer, essa é a lógica interna subjacente a todo discurso pedagógico, formal ou informal. Somente quando alguém compreende a voz que não é jamais escutada, pode-se realmente compreender o que é transmitido. Se isso soa um pouco modesto, segundo sua perspectiva, a maior parte das discussões sobre educação é inteiramente superficial e leva a alguns por caminhos errados e podem ser positivamente perigosas. Os assuntos fundamentais não são levantados e é impossível entender qualquer realização desse dispositivo sem a compreensão de sua estrutura interna. 
A explanação do conceito de Dispositivos Pedagógicos de Bernstein (1990) colaborou para a compreensão das estruturas internas dos Cafés Científicos e para a proposição de novos formatos para esses eventos.

Os Cafés Científicos, embora possuam diferentes configurações ao redor do mundo em torno da mesma proposta - a concepção de ambientes descontraídos para aproximar a comunidade científica e a sociedade civil e levar o conhecimento produzido dentro da esfera da ciência para os cidadãos que se encontram fora dela -, assumem a configuração de um dispositivo pedagógico. Os contextos dos "Cafés" se constituem como espaços de produção de conhecimento que dão voz e valorizam as especificidades dos diferentes saberes, facilitam as trocas culturais e permitem a participam efetiva dos diferentes agentes sociais em um processo de construção, produção e circulação de saberes (LEITE; PACHECO, 2008).

\subsubsection{A seguir, o Projeto Barômetro - ciência, café e debate}

O Projeto "Bar ô metro" - Ciência, café e debate foi fruto de uma parceria entre a Diretoria de Divulgação Científica da UFMG, o Centro Cultural UFMG e a Rádio 104,5 UFMG Educativa. Esse projeto consistiu na concepção de Cafés Científicos no Centro Cultural UFMG e foi planejado para atender a três demandas distintas. A primeira se inseriu dento das próprias diretrizes da atividade de divulgação científica dessa diretoria institucional e acabou por envolver e englobar as outras duas. A segunda atendeu a uma demanda do Centro Cultural UFMG em ocupar seus espaços, tanto físicos quanto institucionais, com atividades relacionadas à cultura e à participação da comunidade de modo geral. E a terceira foi a oportunidade da transmissão do evento através da rádio universitária onde, além da aquisição de uma forma de poderosa de comunicação e divulgação, o projeto atingiu uma dimensão formadora ao inserir em sua equipe estudantes de cursos de graduação da universidade, em especial, alunos do curso de Comunicação Social.

As três demandas acabaram por constituir três vértices ou a tríade, que conferiu a originalidade desse projeto de Café Científico em relação aos demais eventos correlatos ao redor do mundo.

Essa tríade foi composta pela Conferência Pública, o Programa de Rádio e a Interface Digital. 
A Conferência Pública consistiu em:

- a presença de dois debatedores, um representante da comunidade científica e outro representante da sociedade civil;

- a presença do público - presencial e virtual;

- o debate e a interação com o público.

O Programa de Rádio consistiu em:

- o script ou roteiro;

- a presença da música;

- a rádio web;

- a webcam e o Twitter,

- o mapa de palco ou rider técnico;

- a transmissão em tempo real;

- a repórter apresentadora ou repórter âncora;

- a repórter mediadora do dispositivo móvel - a repórter tablet.

A Interface Digital consistiu em:

- o software da Esfera Semântica (ES);

- a projeção da ES;

- a interação através dos dispositivos móveis;

- mediadores na plateia (compartilhamento dos dispositivos móveis);

- a base de dados gerada.

As inovações propostas perpassaram pelos três elementos da tríade, cada qual com sua contribuição e sua importância.

O projeto destinado ao Centro Cultural teve como objetivo criar um ambiente descontraído, onde o ponto principal foi promover a interação entre representantes da comunidade científica, representantes da sociedade civil e público na "Sala do Piano", através de eventos mensais, às $20 \mathrm{~h}$ da última quinta-feira de cada mês, com início no mês de março de 2011.

O nome "Barômetro" foi escolhido por dois motivos: o primeiro, que o barômetro é um instrumento da ciência, utilizado para medir a pressão atmosférica e, durante muito tempo, auxiliou especialistas na previsão do tempo; segundo, pela 
semelhança sintática com a palavra "bar", espaço de convivência que deu para a cidade de Belo Horizonte o título de "Capital Mundial dos Botecos".

Para cada mês, foi planejado um debate em torno de temas que seriam discutidos e relacionados ao conhecimento científico. Os debates foram abertos ao público. A sala do Centro Cultural foi caracterizada como um ambiente de bar, contando, inclusive, com a utilização do piano por músicos convidados. Grupos musicais integrantes de projetos culturais também encontraram no projeto um espaço para divulgação de seus trabalhos.

O tempo previsto para os debates foi de noventa minutos. O evento foi transmitido em tempo real pela rádio 104,5 UFMG Educativa e alunos do curso de Comunicação Social da UFMG fizeram a condução dos debates e a mediação com o público. O público presente participou ao elaborar perguntas e comentários que foram registrados em tablets posicionados nas mesas ou perguntaram diretamente aos debatedores através do microfone. A projeção de uma esfera semântica interativa com expressões relacionadas aos temas ficou à disposição dos participantes.

A seleção de debatedores convidados seguiu o critério, de acordo com o tema escolhido: um debatedor representante da esfera da ciência e outro debatedor relacionado ao tema.

Houve serviço de buffet, de modo que debatedores e público ficaram à vontade para se servirem no decorrer dos debates.

\subsubsection{Da concepção à produção - o Design Instrucional e o papel do Designer}

Em um processo de produção, de implantação de um projeto com ideias que foram cuidadosamente pensadas e elaboradas, há o momento de colocar as ideias no papel e há o momento de executá-las. Até certo ponto, é possível delimitar essas ações, esses momentos, mas, após o processo de implantação, de execução do projeto, as ações foram tomando corpo e fica difícil, em determinados momentos, delimitar espaços.

Com o "Barômetro - Ciência, café e debate" não foi diferente. Mesmo com parâmetros bem definidos, não se sabia se o que foi pensado era passível de ser executado. Os parâmetros diziam que era preciso criar um ambiente descontraído, que acolhesse pessoas da ciência e da sociedade, que fosse favorável ao debate, de modo a estimular a participação do público. Aliado a isso vieram a Interface Digital e o Programa de Rádio. 
Esse meio do caminho, entre uma etapa e outra, ou entre planejar e executar, foi um processo complexo no qual não se sabia o que ia acontecer. Quando se teve elementos inovadores no processo, ficou mais difícil ainda imaginar o que poderia realmente acontecer. Ao mesmo tempo em que o projeto tinha como base um determinado padrão conceitual estabelecido internacionalmente, pode-se dizer um design, ele agregava inovação, que estabeleceria outro padrão, outro design.

Esse caminho percorrido se fundamentou nas concepções do Design Instrucional apresentadas a seguir. Definir objetivos, traçar caminhos para se atingir esses objetivos e entender quando se conseguiu atingi-los, foram ações fundamentais para tirar o projeto "Barômetro" do papel e realizar o primeiro programa e todas as suas edições posteriores.

Seguem, em primeiro lugar, uma concepção sobre Design Instrucional e seus profissionais, após, em segundo, uma noção de Instrução, em terceiro alguns posicionamentos sobre Design e Designer e, em quarto, uma relação dos Processos do Design Instrucional.

Por fim, os autores deixaram claro em suas explanações que Design é um processo que envolve atividades diversas com objetivos definidos. Essa abordagem processual do Design é extremamente interessante, pois deu a ideia de dinamismo, de flexibilidade e permitiu com que a inovação fosse bem recebida.

\subsubsection{Design instrucional}

O termo Instructional Design ou Design Instrucional (DI) se refere ao processo sistemático e reflexivo de tradução de processos de aprendizagem e instrução em planos para materiais instrucionais, atividades, recursos de informação e avaliação. Segundo Smith e Ragan (1999), um designer instrucional é como um engenheiro, ou seja, ambos planejam seu trabalho baseados em princípios que fizeram sucesso no passado - o engenheiro pelas leis da física e o designer pelos princípios básicos de instrução e aprendizagem. Ambos tentam buscar soluções não apenas funcionais, mas atrativas para seus públicos alvos. Ambos prescrevem especificações, planos, para as soluções embora eles não as traduzam no produto em si. Eles com frequência entregam seus planos para um especialista em produção - no caso do engenheiro para um empreiteiro, no caso do designer instrucional para um especialista em produção de mídia. Entretanto, alguns designers com habilidades de produção fazem eles próprios a tradução de suas especificações para o material 
instrucional final. No caso de professores, por exemplo, eles próprios implementam seus planos.

O planejamento sistemático é necessário, não importa qual seja a mídia de instrução utilizada para a implantação. Quando o principal mediador da instrução é um professor, um educador, ou quando esse professor/educador assume a função de coordenador da instrução, a qualidade do DI é automaticamente beneficiada. O planejamento sistemático anterior ao processo de implantação e a reflexão do que pode acontecer depois são informados, orientados e organizados pelos princípios e processos do DI. Um planejamento cuidadoso permite que adaptações sejam feitas durante a instrução com base em experiências anteriores dos instruídos, assim como problemas de motivação, comportamento ou de ordem administrativa ou mesmo eventos casuais que requerem planejamento local.

\subsubsection{Instrução}

Smith e Ragan (1999) entenderam como instrução a facilitação instrucional da aprendizagem direcionada a objetivos de aprendizagem identificados. Uma perspectiva similar foi adotada por Driscoll (1994, p. 332) citado por Smith e Ragan (1999, p. 2), que compreende instrução como o arranjo deliberado de condições de aprendizagem para promover a realização de um objetivo pretendido. Para os autores, nas duas definições, instrução consiste de um arranjo intencional de experiências direcionado para que os aprendizes adquiram capacidades particulares.

Os autores lembraram que o termo instrução é frequentemente utilizado de forma alternada com os termos educação, treinamento e ensino. Em seu texto, foram realizadas algumas distinções que eles julgaram imprescindíveis para estruturar seu trabalho. Assim, eles utilizaram o termo educação em uma perspectiva ampla para descrever as experiências através das quais as pessoas aprendem. Muitas dessas experiências não foram planejadas, são incidentais e informais. Então, toda instrução é parte da educação, já que toda instrução consiste de experiências direcionadas para a aprendizagem. Mas nem sempre educação é instrução porque muitas experiências que são direcionadas para a aprendizagem não foram especificamente desenvolvidas e implementadas para serem eficazes, eficientes e apelativas e direcionadas para objetivos particulares de aprendizagem. Por treinamento, eles se referiram às experiências instrucionais que são focadas na 
aquisição de habilidades específicas individuais que serão colocadas em prática imediatamente. E, por último, o termo ensino, que para eles se referiu às experiências de aprendizagem facilitadas por um ser humano, um professor. Smith e Ragan (1999) enfatizaram que as ferramentas e os princípios do DI descritos por eles são aplicados em todas as formas de experiência, enquanto a experiência em questão tenha a facilitação de objetivos particulares para a aprendizagem em seus propósitos.

Como o foco é sobre a instrução, eles a consideraram como um subconjunto da educação. $O$ termo treinamento é um subconjunto da instrução. Em alguns casos, o ensino será considerado instrução e, em outros, tenderá mais para educação, mas não sob o foco que caracteriza a instrução. Os autores se concentraram no design e no desenvolvimento de atividades que são direcionados para objetivos de aprendizagem identificados.

\subsubsection{O Design e o Designer}

Diferentes áreas fazem uso do termo design como parte de seus títulos, de suas designações: design de interiores, design industrial, design de arquitetura, entre outros. O termo design, para Smith e Ragan (1999), implica no planejamento sistemático ou intenso e na idealização de processos anteriores ao desenvolvimento de algo ou da execução de um plano para resolver algum problema. Em seu texto, os autores classificaram a capacidade que os designers aplicam ao "domínio específico para solução de problemas", o que envolve a solução de problemas mal estruturados e mal definidos. Tais problemas não podem ser resolvidos por um algoritmo e nem todos os designers alcançarão a mesma solução para os problemas particulares de aprendizagem.

O design se distingue de outras formas de planejamento instrucional pelo seu nível de precisão, cuidado e expertise que é empregado no planejamento, desenvolvimento e avaliação dos processos. Designers, por sua vez, empregam alto nível de precisão, cuidado e expertise no desenvolvimento sistemático da instrução, pois eles perceberam que um planejamento pobre pode resultar em sérias consequências tais como, mau uso do tempo e outros recursos.

O design envolve a consideração de muitos fatores que podem afetar ou afetam a implementação de um plano instrucional. Se esses fatores não forem 
considerados e a forma como eles se inter-relacionam, os designers correm o risco de criar um trabalho ou um espaço vivo que é inutilizável ou até mesmo perigoso. A criatividade tem um papel fundamental no design. Suas instruções devem ser inspiradoras e memoráveis e bons designers mantêm claro o objetivo principal e a percepção generalizada do conteúdo dos diversos materiais.

Outro aspecto do DI é sua natureza extensa e exigente. Designers experientes expressam com frequência suas preocupações em relação ao tempo e ao esforço gasto na aplicação do que é conhecido sobre design eficiente, efetivo e uma instrução atraente.

Para finalizar, estão algumas reflexões pontuadas por Smith e Ragan (1999), das observações de Rowland (1992, p.65-86), citado por Smith e Ragan (1999, p.5), tiradas de seu estudo sobre processos de design, entre diversos profissionais do design instrucional:

- Design é um processo direcionado a um objetivo no qual o objetivo é conceber e realizar algo novo;

- Esse algo novo, resultante da atividade do design, tem utilidade prática;

- A tarefa básica da atividade do design é converter informação na forma de requisitos, em informação na forma de especificações;

- Design requer interação social;

- A atividade do design envolve solução de problemas, mas nem todos os problemas resolvidos são atividade do design;

- $\mathrm{Na}$ atividade do design, entendimento do problema e solução do problema podem ser processos simultâneos ou sequenciais;

- Design pode ser uma ciência, ou a combinação de ciência e arte, ou nem ciência nem arte;

- A atividade do design requer habilidades técnicas e criatividade e processos de pensamento racionais e intuitivos;

- Um processo de design é um processo de aprendizagem.

\subsubsection{Processos do Design Instrucional}

Outra forma de definir DI é descrever os processos envolvidos no planejamento sistemático da instrução. Desde o nível mais baixo, o trabalho do designer instrucional é responder a três questões primordiais, que são: Para onde 
estamos indo ou quais são os objetivos da instrução? Como chegaremos até lá ou o que é estratégia instrucional ou meio instrucional? Como saberemos quando chegamos ou quais deveriam ser os testes ou ainda como avaliaremos ou revisaremos os materiais instrucionais?

Essas três questões puderam ser estabelecidas como atividades principais que o designer instrucional complementa durante o processo de design e desenvolvimento. Realizar uma análise instrucional para determinar "onde estamos indo"; desenvolver uma estratégia instrucional para determinar "como chegaremos lá"; desenvolver e conduzir uma avaliação para determinar "como saberemos quando chegamos lá".

No decorrer do texto, foram introduzidos alguns dos posicionamentos e ações, tanto de ordem conceitual quanto de ordem organizacional, que foram tomados para a concepção do projeto "Barômetro - Ciência, café e debate". Essa parte do texto se dedicou aos detalhamentos, ações e decisões ocorridos internamente, de modo a buscar o refinamento do modelo diferenciado de Café Científico proposto e, ao mesmo tempo, investigado nesta pesquisa. As tomadas de decisões aqui relatadas se configuraram ao longo do andamento do projeto e possuíram um caráter mais prático, embora fundamentado por referências conceituais.

Detalhamentos, decisões, abordagens, não importa de qual ordem, fizeram parte do desenho, do design, que se construiu desde o momento de concepção e escrita do projeto até o seu funcionamento. Da primeira visita à Sala do Piano no Centro Cultural UFMG até os debates nos programas mensais transmitidos em tempo real nas últimas quintas-feiras de cada mês, toda essa trajetória delineou, aos poucos, o processo do design do "Barômetro - Ciência, café e debate".

\subsubsection{A tríade em ação - instrução e design}

As ações realizadas, sejam na fase de concepção do projeto, sejam na fase de produção do projeto, ora se restringiam a um dos vértices da tríade isoladamente, ora se mesclavam entre eles. Em alguns momentos, foi possível identificá-las separadamente, em outros, não. O conjunto das ações acabou por delinear outro padrão de Café Científico, outro design, com processos instrucionais definidos e inovadores. 


\subsubsection{Accões da Conferência Pública}

\section{Delinear o perfil dos debatedores}

Os debatedores se dividiram entre representantes da comunidade científica e representantes da sociedade civil. Foi preciso definir quem seriam esses representantes.

Para os representantes da comunidade científica ficou definido que seriam professores universitários com título de doutor, envolvidos em atividades relacionadas à pesquisa.

Para os representantes da sociedade civil, ficou definido que não teriam a titularidade de mestre ou doutor e, portanto, não estariam envolvidos em atividades de pesquisa acadêmica. Esses debatedores teriam de ter algum tipo de representatividade em relação aos temas que seriam debatidos.

Segue o Quadro 2 com os perfis gerais dos debatedores da comunidade científica e da sociedade civil:

Quadro 2 - Debatedores - perfis gerais

\begin{tabular}{|l|l|}
\hline $\begin{array}{l}\text { Debatedores } \\
\text { representantes da } \\
\text { Comunidade Científica }\end{array}$ & $\begin{array}{l}\text { 8 debatedores: doutores - 7 professores de instituições } \\
\text { universitárias públicas federais e 1 professor de instituição } \\
\text { universitária particular. }\end{array}$ \\
\hline $\begin{array}{l}\text { Debatedores } \\
\text { representantes da } \\
\text { Sociedade Civil: }\end{array}$ & $\begin{array}{l}\text { 8 debatedores: não teriam de possuir necessariamente } \\
\text { algum tipo de escolaridade, mas deveriam ter algum tipo } \\
\text { de representatividade e conhecimento em relação aos } \\
\text { temas debatidos. }\end{array}$ \\
\hline
\end{tabular}

Fonte: Elaborado pela autora.

Tais definições guiaram o convite aos debatedores que participaram dos programas. O Quadro 3 apresenta os perfis detalhados dos debatedores e suas relações com os temas no ano de 2011:

Quadro 3 - Debatedores - perfis detalhados

\begin{tabular}{|c|c|l|l|}
\hline Café & $\begin{array}{c}\text { Tema - } \\
\text { Ciência e }\end{array}$ & $\begin{array}{c}\text { Representante Comunidade } \\
\text { Científica }\end{array}$ & $\begin{array}{c}\text { Representante Sociedade } \\
\text { Civil }\end{array}$ \\
\hline 1 & Samba & Físico - professor/doutor & Sambista \\
\hline 2 & Dengue & Médico - professor/doutor & Dona de casa/ Diarista \\
\hline 3 & Arte & Químico - professor/doutor & Artista Plástico \\
\hline 4 & Design & Químico - professor/doutor & Designer \\
\hline
\end{tabular}


(Continuação)

\begin{tabular}{|c|c|c|c|}
\hline Café & $\begin{array}{c}\text { Tema - } \\
\text { Ciência e }\end{array}$ & $\begin{array}{l}\text { Representante Comunidade } \\
\text { Científica }\end{array}$ & $\begin{array}{c}\text { Representante Sociedade } \\
\text { Civil }\end{array}$ \\
\hline 5 & Religião & Historiador - professor/doutor & Espiritualista - psicólogo \\
\hline 6 & $\begin{array}{l}\text { Sala de } \\
\text { Aula }\end{array}$ & Químico - professor/doutor & $\begin{array}{l}\text { Diretor de escola pública - } \\
\text { geógrafo }\end{array}$ \\
\hline 7 & Astrologia & Geógrafo - & $\begin{array}{l}\text { Astrólogo, tarólogo, jogador } \\
\text { de búzios }\end{array}$ \\
\hline 8 & $\begin{array}{l}\text { Inclusão } \\
\text { Social }\end{array}$ & Poeta - professora/doutora & $\begin{array}{l}\text { Ex-morador de rua - vice- } \\
\text { presidente financeiro de uma } \\
\text { associação de catadores de } \\
\text { papel }\end{array}$ \\
\hline
\end{tabular}

Fonte: Elaborado pela autora.

\section{Escolher os temas dos eventos}

A escolha dos temas partiu de um viés pragmático e acabou por atender a algumas demandas da coordenação do projeto. O critério inicial veio da proposição feita pela coordenação do projeto - o primeiro evento seria Ciência e Samba porque aconteceria no mês de Março, época em que tradicionalmente se comemora - Carnaval no Brasil. A partir desse critério, os temas foram propostos ao estabelecer a relação entre ciência e os acontecimentos simbólicos de cada mês. Dessa forma, assim ficou a relação:

- Abril - mês em que se comemora a páscoa, a ressurreição de cristo;

- Maio - mês que se comemora a Semana Nacional de Museus no Brasil e outros eventos correlatos na Europa;

- Junho - tema escolhido pelos debatedores desse mês desde o início do projeto (os debatedores entraram em contato com a equipe de produção e se propuseram a participar);

- Julho - mês das férias escolares em que, geralmente, os cinemas têm uma programação especial nessa data (filmes infanto-juvenis);

- Agosto - mês do desgosto, como é popularmente conhecido;

- Setembro - mês em que se comemora a independência do Brasil;

- Outubro - mês em que se comemora a Semana Nacional de Ciência e Tecnologia;

- Novembro - mês em que se comemora a Consciência Negra no Brasil.

Em função de algumas demandas da coordenação do projeto, alguns temas 
foram substituídos ou remanejados da data prevista. A flexibilidade das diretrizes do projeto contribuiu para esse momento de ajustes. Os temas que ainda não foram debatidos serão retomados em eventos futuros.

Quadro 4 - Relação entre temas propostos e temas definidos

\begin{tabular}{|c|c|l|l|}
\hline Café & Mês & Tema Proposto/ Produção & \multicolumn{1}{|c|}{$\begin{array}{c}\text { Tema Definido/ } \\
\text { Coordenação }\end{array}$} \\
\hline 1 & Março & Samba & Samba \\
\hline 2 & Abril & Religião & Dengue \\
\hline 3 & Maio & Museus & Arte \\
\hline 4 & Junho & Design & Design \\
\hline 5 & Julho & Cinema de ficção científica & Não houve evento \\
\hline 6 & Agosto & Superstições & Religião \\
\hline 7 & Setembro & Política & Sala de Aula \\
\hline 8 & Outubro & $\begin{array}{l}\text { Ciência, tecnologia e } \\
\text { sociedade }\end{array}$ & $\begin{array}{l}\text { Astrologia (mudanças } \\
\text { climáticas) }\end{array}$ \\
\hline
\end{tabular}

Fonte: Elaborado pela autora.

\subsubsection{Acões do Programa de Rádio - a dinâmica do "Café" e sua insercão no rádio}

O projeto foi pensado, a princípio, nos moldes dos Cafés Científicos. Em seguida, devido ao seu engajamento com a pesquisa, vieram as demarcações conceituais. No decorrer do processo, ainda em seu início, veio a parceria com a rádio educativa da universidade, fato que fez com que outros rumos fossem tomados. No lugar do animador "científico", entraram novos atores para fazer a condução e a mediação entre debatedores e público. O debate ganhou nova dinâmica, novo ritmo, que passou a exigir, a partir de então, um entrosamento mais afinado entre as partes. A mediação se transformou no elemento fundamental que conferiu não somente essa nova dinâmica, mas, consequentemente, uma de suas particularidades diante dos outros eventos.

\section{Elaborar a mediação}

O modelo padrão de funcionamento dos "Cafés" tem na figura de um "animador" a função de realizar a mediação dos eventos. Em alguns países, o animador é um jornalista científico, em outros, é um cientista que possui habilidades de se comunicar com o público. O Projeto "Barômetro" transformou um evento de 
Café Científico em um programa de rádio transmitido em tempo real. Esse fato não apenas conferiu novo formato ao modelo inicial, como trouxe para a mediação novos elementos. No lugar de jornalistas científicos e cientistas habilidosos em falar com o público, entraram em cena alunos do Curso de Comunicação Social da instituição. A mediação foi organizada em equipe, um aluno se encarregou de fazer a interlocução entre os dois debatedores e outro aluno fez a mediação com o público. Os outros estudantes coordenaram e conduziram a dinâmica do programa e selecionaram as perguntas que foram passadas para os debatedores. O evento ganhou uma dimensão formadora e foi ao encontro das diretrizes institucionais da rádio.

A presença desses alunos na condução do processo de interação entre debatedores e público foi fundamental para garantir a participação equilibrada das três representatividades principais do programa: representante da comunidade científica/representante da sociedade civil/público. Dentro dos parâmetros de um veículo de comunicação de massa, não cabe a participação desigual das partes. Essa foi uma regra externa que contribuiu para a configuração do projeto.

\section{O roteiro ou script - A transmissão em tempo real}

A transmissão em tempo real exigiu a elaboração de um roteiro que reunisse repórteres da rádio, debatedores e músicos, também criasse uma dinâmica que privilegiasse a participação de todos de forma equilibrada. Segue o roteiro previsto:

- Duração da transmissão: 120 minutos - 90 minutos de debate e apresentação musical/ 30 minutos somente com a apresentação musical;

- Inicio: 20h/ Término: 22h;

- Duração do debate: $20 \mathrm{~h} 05$ até 21h30;

- 2': Abertura do programa - locução equipe rádio;

- 3': 1를 Apresentação musical;

- 7': Apresentação dos debatedores pela equipe da rádio - cada debatedor se apresentou;

- 20': Entrada da repórter da rádio responsável por transmitir as perguntas aos debatedores e dar início ao debate - interação através dos tablets;

- $3^{\prime}: 2^{\text {a }}$ Apresentação musical;

- 20': Entrada da repórter da rádio para dar início ao segundo momento de debate - interação através dos tablets e perguntas feitas pelo microfone; 
- 21h: Final da primeira parte da transmissão;

- 3': Transmissão institucional da UFMG;

- $3^{\prime}$ : $3^{\underline{a}}$ Apresentação musical;

- 24': Entrada da repórter da rádio para dar início ao terceiro e último momento de debate - interação através dos tablets;

- 21h30: Final do debate;

- 30': Os 30 minutos finais ficaram por conta da apresentação musical convidada para participar do evento;

- 22h: Final da transmissão.

As transmissões aconteceram dentro do roteiro previsto, embora algumas vezes os momentos e o tempo destinados às perguntas tenham aumentado ou diminuído. A flexibilidade foi um dos pontos mais positivos do roteiro. Perguntas interessantes e colocações dos debatedores garantiram sua elasticidade. A música deu, nesses momentos, um toque especial.

\section{A presença da música}

A música esteve presente desde o primeiro momento de planejamento do projeto. O espaço físico destinado ao evento era propício para isso e possuía, inclusive, um piano de cauda e um nome convidativo - Sala do Piano.

Mas, independente dessa junção de fatos, as apresentações musicais acabaram submetidas, não com tanta rigidez, aos posicionamentos conceituais tomados para o debate. Do total de oito grupos de músicos convidados, seis executaram trabalho autoral e nas duas apresentações restantes, um trouxe para o programa instrumentos antigos com repertório bem específico, enquanto o outro se dedicou a tocar o piano disponível na sala com repertório que foi do popular ao erudito.

A presença da música teve ainda outras funções. Além de abrir e fechar os blocos debate, ela trouxe momentos de reflexão e de equilíbrio que permitiram distribuir as perguntas de forma a assegurar a participação das partes. Os intervalos proporcionados foram imprescindíveis para a tomada de decisões em relação às mudanças de rumo, às vezes necessárias e não programadas.

Para o público participante, as apresentações musicais proporcionaram uma pausa nos debates e garantiram um tempo a mais para as conversas e as 
negociações entre os presentes diante dos tablets para a elaboração das perguntas e comentários enviados.

O Quadro 5 trouxe os critérios de escolha das apresentações musicais e as possíveis relações com os temas abordados nos debates.

Quadro 5 - Critérios de escolha — relação apresentação musical x temas

\begin{tabular}{|c|c|c|c|}
\hline Café & Tema & Grupo musical & $\begin{array}{c}\text { Relação Tema x Grupo } \\
\text { musical }\end{array}$ \\
\hline 1 & Samba & $\begin{array}{l}\text { Sambistas da Velha Guarda } \\
\text { do samba de Belo Horizonte }\end{array}$ & $\begin{array}{l}\text { Um dos sambistas participou } \\
\text { como debatedor }\end{array}$ \\
\hline 2 & Dengue & $\begin{array}{l}\text { Grupo finalista do Projeto } \\
\text { Vozes do Morro/ Belo } \\
\text { Horizonte }\end{array}$ & $\begin{array}{l}\text { Grupo musical cujos } \\
\text { integrantes são moradores } \\
\text { da Comunidade Morro das } \\
\text { Pedras }\end{array}$ \\
\hline 3 & Arte & Pianista & $\begin{array}{l}\text { Uso do piano existente na } \\
\text { sala e repertório (música } \\
\text { erudita) }\end{array}$ \\
\hline 4 & Design & $\begin{array}{l}\text { Rapper finalista do Projeto } \\
\text { Vozes do Morro/r Belo } \\
\text { Horizonte e atuanter do } \\
\text { Projeto Cidade Hip Hop/ } \\
\text { Belo Horizonte }\end{array}$ & Sem relação direta \\
\hline 5 & Religião & Grupo de música antiga & $\begin{array}{l}\text { Repertório e utilização de } \\
\text { instrumentos antigos }\end{array}$ \\
\hline 6 & $\begin{array}{l}\text { Sala de } \\
\text { Aula }\end{array}$ & $\begin{array}{l}\text { Grupo musical que surgiu } \\
\text { nos anos de } 1970 \text { e } 1980 \\
\text { formado por ex-alunos, hoje } \\
\text { professores, da UFMG }\end{array}$ & $\begin{array}{l}\text { Temas das músicas } \\
\text { relacionados aos conteúdos } \\
\text { da física e a química, um } \\
\text { dos músicos participou como } \\
\text { debatedor }\end{array}$ \\
\hline 7 & $\begin{array}{l}\text { Astrologia/ } \\
\text { Tarô/Búzios }\end{array}$ & $\begin{array}{l}\text { Grupo musical instrumental } \\
\text { formado por jovens } \\
\text { estudantes }\end{array}$ & Sem relação direta \\
\hline 8 & $\begin{array}{l}\text { Inclusão } \\
\text { Social }\end{array}$ & $\begin{array}{l}\text { Grupo de rock participante } \\
\text { do Projeto "Favela é isso aí!" }\end{array}$ & $\begin{array}{l}\text { Grupo de rock formado por } \\
\text { moradores do Aglomerado } \\
\text { da Serra/ Belo Horizonte e } \\
\text { repertório }\end{array}$ \\
\hline
\end{tabular}

Fonte: Elaborado pela autora.

\section{O presencial e o virtual - o espaço que transcendeu}

A palavra "espaço" foi utilizada, ao longo do texto, várias vezes para designar ou para localizar o lugar ou os lugares dos Cafés Científicos. O lugar que delimitou seu território no espaço não escolar, que não se enquadrou nos moldes acadêmicos e, ao mesmo tempo, o lugar que caracterizou e materializou esse território. 
O rádio transcendeu tudo isso. O número de participantes se multiplicou na figura do ouvinte, as tecnologias das redes sociais colocaram a bordo internautas dos mais diferentes lugares. O "Café" não se restringiu mais à Sala do Piano. O espaço ganhou novas dimensões, outros públicos e, 'num piscar de olhos', ampliouse. Embora se tenha essa noção do espaço ampliado é bom salientar que estudos de público e índices de audiência ainda estão em fase de implantação na rádio universitária. Durante as transmissões, foi possível verificar os índices de audiência vindos de usuários da internet, ou seja, índices relacionados ao número de computadores sintonizados na rádio no momento do programa. Segundo a equipe de transmissão da rádio, os índices foram extremamente satisfatórios e chegaram a atingir picos de audiência em relação à programação da rádio de forma geral.

\subsection{Os bastidores da transmissão}

Cada noite de transmissão significou o ponto final de um trabalho que teve início pelo menos um mês antes.

\section{Debatedores}

Para cada debatedor convidado, foi feito um levantamento acerca de seus dados profissionais e demais informações que pudessem interessar para o evento. As informações dos debatedores representantes da comunidade científica foram buscadas pelo resumo disponível na plataforma lattes. Para os debatedores representantes da sociedade civil, foram realizados contatos telefônicos ou encontros pessoais. Esse material era enviado à equipe da rádio, assim como os contatos pessoais dos debatedores, para maiores esclarecimentos, caso fosse preciso. O mesmo procedimento foi realizado com os grupos musicais.

\section{Debatedores e músicos - processos de negociação}

Os contatos com os convidados do projeto - debatedores e músicos foram realizados com antecedência de pelo menos um mês antes da data dos eventos. A confirmação da presença desses convidados foi o resultado de um cuidadoso processo de negociação, às vezes longo, às vezes nem tanto. $O$ ineditismo do projeto foi um dos fatores que colaborou para essa situação. Em determinados momentos, um simples telefonema foi suficiente para conseguir a 
participação do convidado. Mas, em outros momentos, os contatos não se resumiram a apenas isso. Foi necessário o encontro frente a frente, a apresentação de material escrito, previamente enviado por correio eletrônico e a explicação detalhada de toda a dinâmica do debate.

O contato com os músicos também foi outro momento de negociação, uma vez que o projeto não possuía verba para arcar com suas apresentações. Foi preciso conseguir o engajamento dos mesmos na proposta conceitual do projeto. Em algumas situações, foi necessário também ir até a eles para conseguir suas adesões. A contrapartida do projeto foi a divulgação do trabalho dos músicos na rádio e a disponibilização dos 30 minutos finais da transmissão somente para os grupos musicais. A rádio podia ocupar, nas noites dos programas do projeto, até duas horas de sua programação. $O$ interessante foi que a grande maioria dos grupos musicais que se apresentou trouxe para o espaço de debate um trabalho autoral que, de certa forma, adequou-se à missão formadora da rádio e à dinâmica do "Café".

\subsubsection{Ações da Interface Digital - a Esfera Semântica, a interface inovadora da interacão}

Foto 1 - Barômetro Ciência e Dengue, Sala do Piano, Centro Cultural UFMG

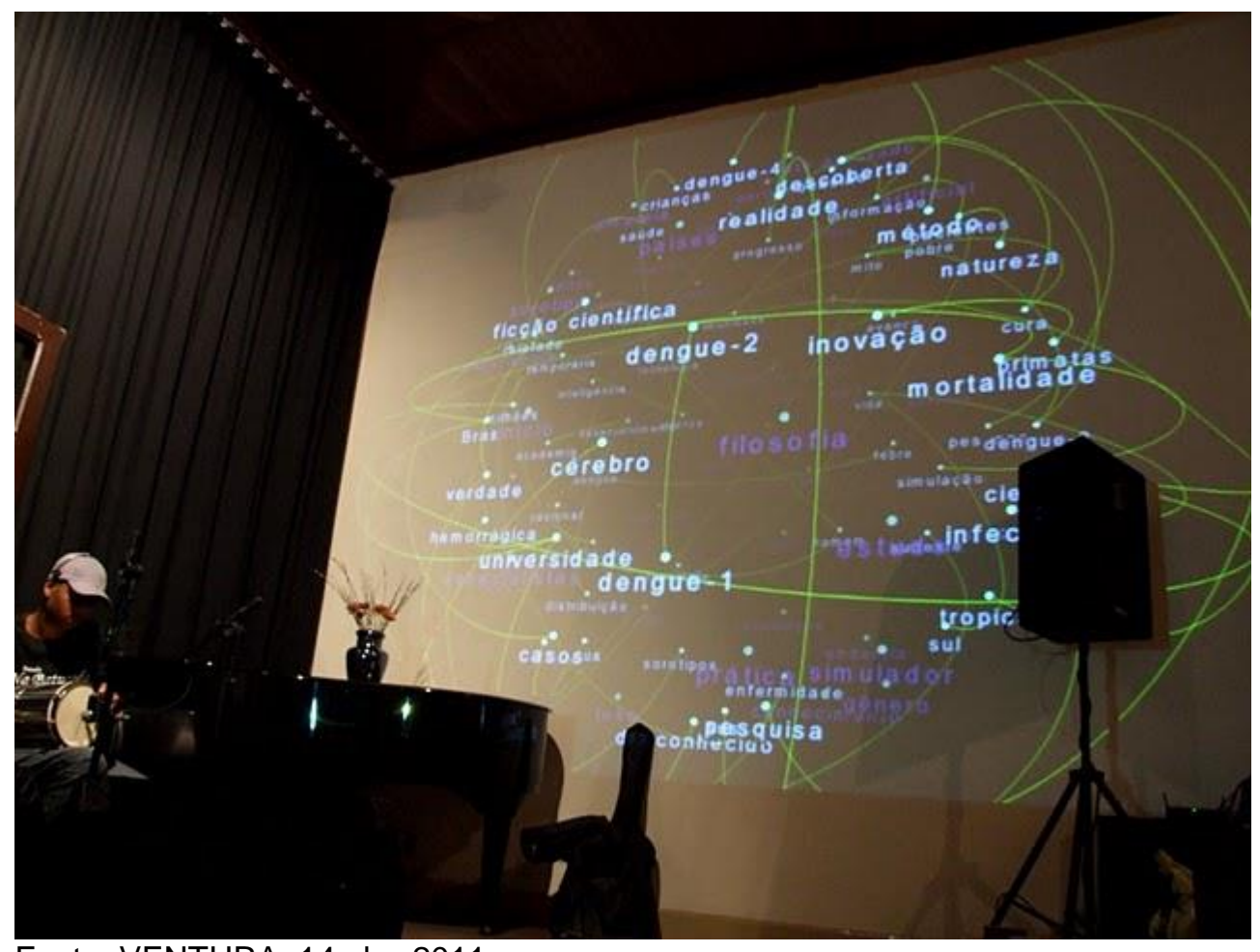

Fonte: VENTURA, 14 abr. 2011. 
Foto 2 - Público participante recebendo instruções para manusear o tablet, Barômetro Ciência e Samba, Sala do Piano, Centro Cultural UFMG

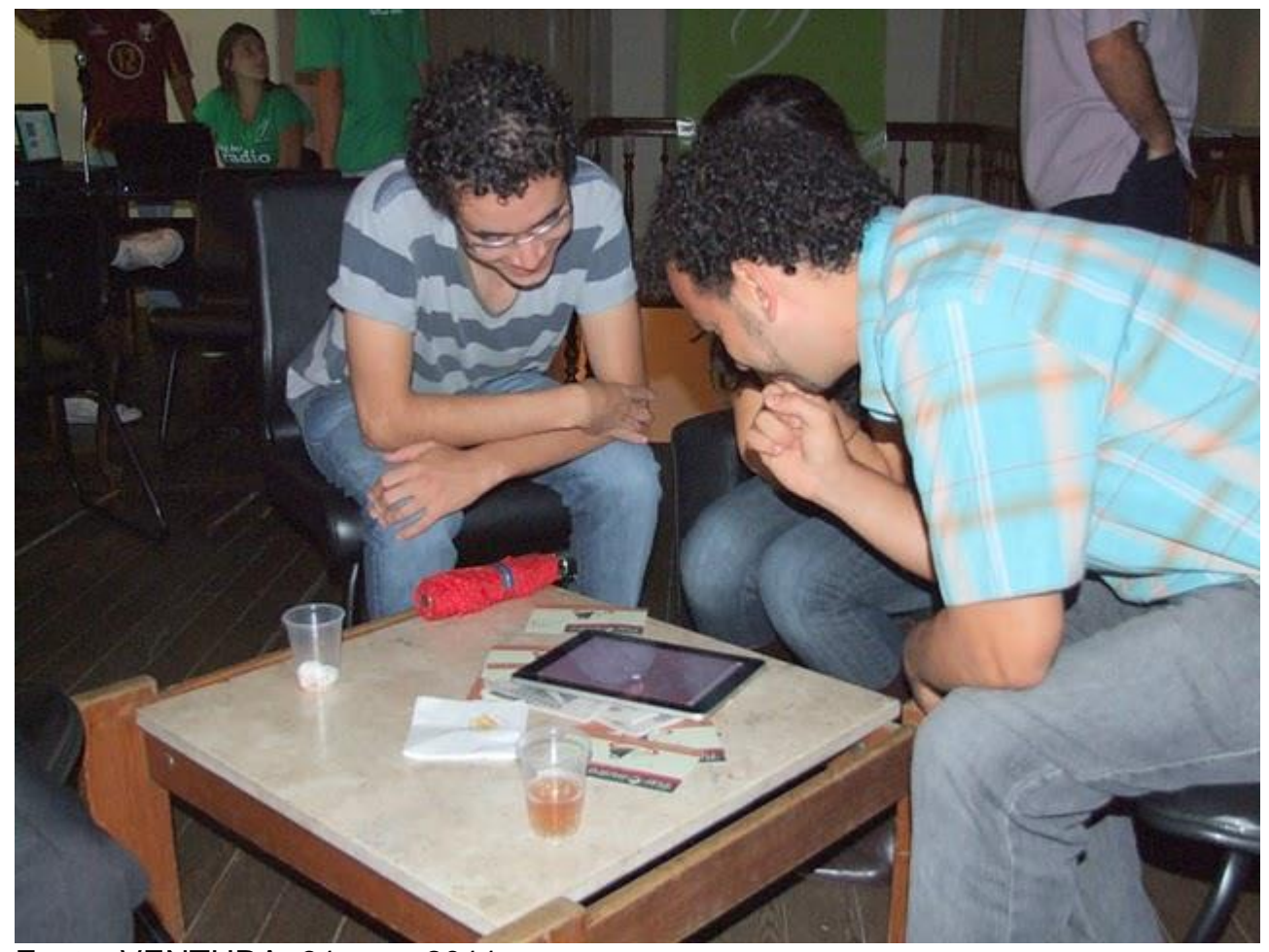

Fonte: VENTURA, 31 mar. 2011.

A esfera semântica foi um software especialmente concebido para o Projeto "Barômetro" (FOTO 1) e se constituiu em um dos mecanismos de coleta de dados primordiais da pesquisa. A cada evento, a esfera foi alimentada com dois conjuntos de palavras: um permanente, com palavras que pertencem ao campo semântico da ciência e outro, mutável, com palavras que pertencem ao campo semântico do tema escolhido para o evento. $O$ objetivo foi oferecer aos participantes dos debates a oportunidade de estarem sempre relacionando ou confrontando palavras geralmente relacionadas à ciência com palavras de outras áreas do conhecimento previstas na programação.

Os conjuntos de palavras foram apresentados aos participantes em tablets dispostos em uma esfera virtual (FOTO 2). Através de toques, frases, comentários e perguntas puderam ser elaborados por meio de um teclado, também virtual, e enviados imediatamente para a mesma esfera projetada e disponibilizada a todos os presentes no ambiente. Uma parte desse material textual elaborado (perguntas e comentários) foi transmitida aos debatedores para ser discutido no momento do debate e todo esse material foi armazenado em um banco de dados disponibilizado para a pesquisa. 
A esfera de significados, a Esfera Semântica, foi um dos, senão o principal diferencial do "Barômetro - ciência, café e debate". A disponibilidade de palavras à mercê do público e a oportunidade de elaborar frases, perguntas, comentários e ainda assim garantir o anonimato provocou, a cada evento, a participação significativa de sua audiência. Um conjunto de palavras que gerou combinações de termos, que gerou perguntas ou comentários, que acabaram por dar início aos debates e por definir seus rumos.

A seleção das palavras foi realizada através da internet em artigos científicos e sites afins e procurou levar à esfera significados que abrangessem os campos semânticos de forma representativa. Lévy (2011) argumentou que uma memória digital comum e participativa está sem processo de ser criada para toda a humanidade. Para ele, o início do século XXI ficou marcado pela limitação do uso dessa memória devido a problemas como a opacidade semântica, a incompatibilidade de classificação dos sistemas e a fragmentação linguística e cultural. A falta de modelos computacionais trouxe certa incapacidade de automatizar muitos modelos cognitivos de analisar, filtrar, sintetizar e interconectar a informação, de forma que fosse possível tirar melhor proveito do grande volume de dados disponibilizados. Segundo Lévy (2011), ainda não se sabe como transformar esse oceano de dados de forma sistematizada em conhecimento e, menos ainda, como transformar a mídia digital em um observatório que venha a refletir a inteligência coletiva. O principal objetivo do autor é apresentar à comunidade científica e à sociedade como um todo um novo sistema público para codificar significados que permitirão que as operações em significados na nova memória digital se tornem transparentes, com padrões abertos ou interoperabilidade computáveis. Esse sistema de códigos semânticos o autor denomina de Information Economy Meta Language (IEML), que se traduz em, Meta Linguagem da Economia da Informação. Através desse sistema, os obstáculos que hoje impedem uma exploração otimizada do meio digital para servir ao desenvolvimento humano em suas dimensões sociais e pessoais seriam eliminados.

A abordagem de Lévy (2011) é interessante quando ele fala que a "IEML Semantic Sphere" ou a Esfera Semântica MLEl é um protocolo intelectual para a expansão das possibilidades do diálogo interpretativo em torno da memória digital comum. E esse diálogo deve ser entendido como translinguístico, transcultural, transreligioso, transpartidário, transdisciplinar e transinstitucional. Isso acontece 
porque a topologia semântica aberta pela IEML metalinguagem acolhe todos os pontos de vista de ordem prática, ontológica ou filosófica e os considera legitimamente iguais. A única atitude que não é permitida por essa perspectiva geral é a de negar a legitimidade dos pontos de vista de outros, a de recusar o diálogo e a de se fechar.

O processo de busca das palavras seguiu essa abertura e procurou levar para a esfera palavras e termos típicos e característicos dos temas abordados, respeitando seus pontos de vista. Um dos objetivos foi o de permitir, principalmente para os representantes da sociedade civil, encontrarem sua área de conhecimento representada, e para o público participante, encontrar na esfera significados que não somente os da ciência, de forma que ele pudesse estabelecer conexões ao mesmo tempo inusitadas e flexíveis.

\subsubsection{Processos afins de design e instrucão}

\section{Construir a identidade do projeto}

Paralelo ao desenvolvimento do desenho do projeto, outro procedimento começou a tomar corpo: a construção da identidade do projeto. Nessa etapa, houve a proposição de três perspectivas: a identidade visual, a identidade temporal e a identidade textual.

\section{A identidade visual}

Em primeiro lugar, veio a proposição de sua identidade visual através da criação de um logotipo que unisse o título do projeto com o objeto símbolo que o nomeia, ou seja, a xícara de café (FIGURA 2). O logotipo foi criado de forma a apresentar flexibilidade de adaptação em relação aos temas ao ser reproduzido no material gráfico para divulgação, cartazes e pop cards (FIGURAS 2 e 3). A equipe do Centro de Comunicação da UFMG (CEDECOM) foi responsável pela criação do logotipo. 
Figura 2 - Pop card Barômetro Ciência e Dengue

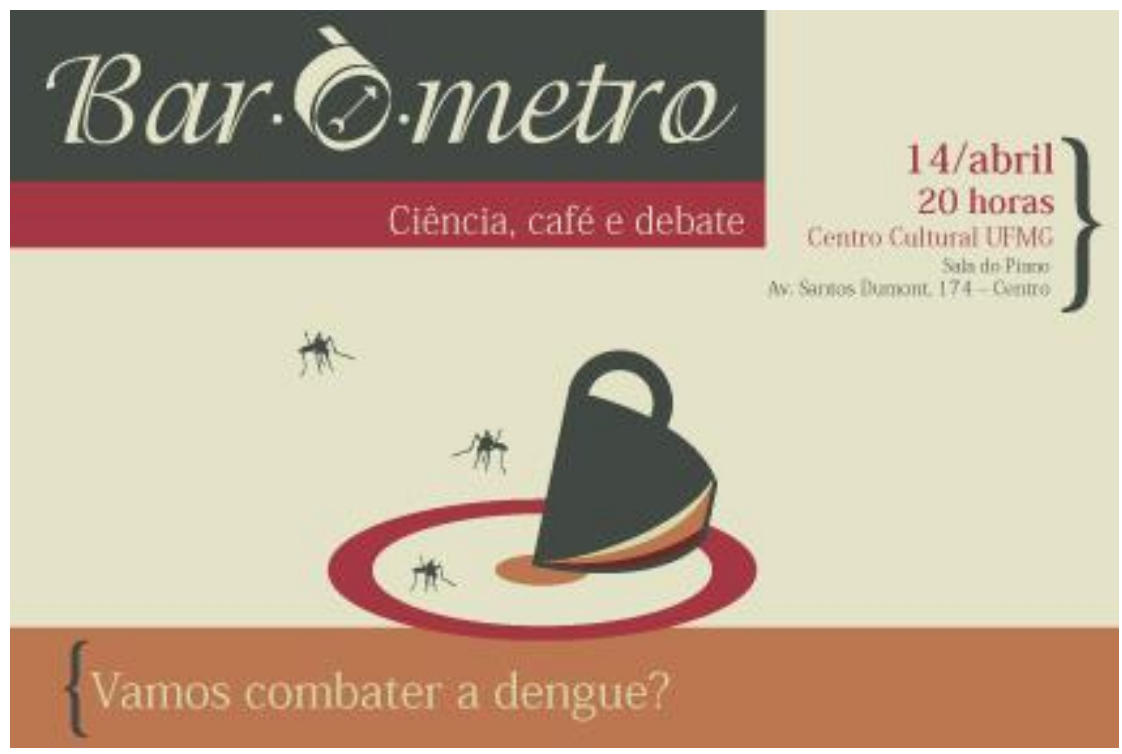

Fonte: Criação equipe CEDECOM/UFMG, abr. 2011.

Figura 3 - Pop card Barômetro Ciência e Samba Bar.metre

Ciência, café e debate

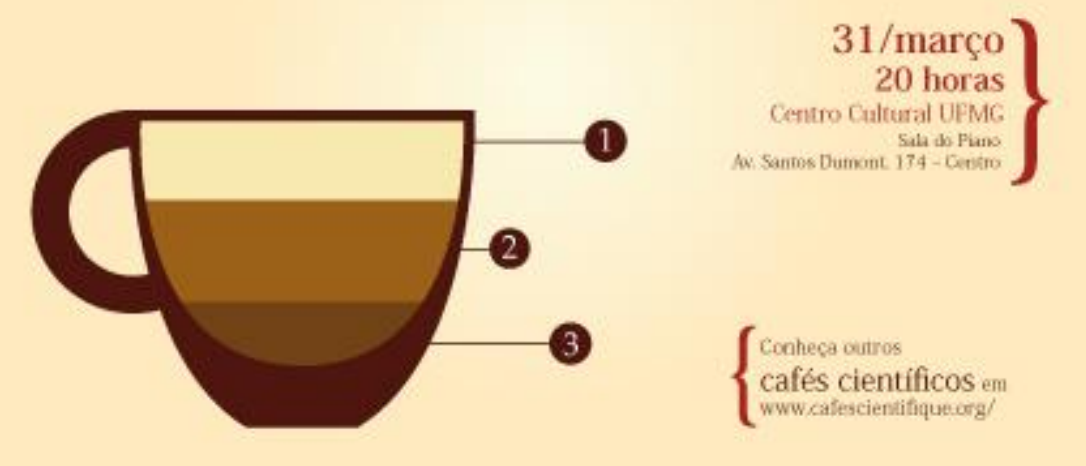

Fonte: Criação equipe CEDECOM/UFMG, mar. 2011.

\section{A identidade temporal}

Outro fato que contribuiu para a formação dessa construção foi a proposição do cronograma. Os eventos ocorreram na última quinta-feira de cada mês no ano de 2011, com exceção do mês de abril que, por motivo de agenda, aconteceu na segunda quinta-feira desse mês. A demarcação temporal - a última quinta do mês — independente da data, foi um dos critérios elaborados para fortalecer a identidade do projeto. Para seus participantes e, pode-se dizer, frequentadores, a ideia foi a de 
facilitar a memorização da data sem que fosse necessária a memorização de números. Esse mesmo procedimento acontece nos demais Cafés Científicos mundo afora.

\section{A identidade textual}

A elaboração dos textos do material de divulgação foi outro fator de extrema importância e mereceu, da parte da produção, atenção especial.

\section{O papel dos textos na divulgação}

O processo de elaboração dos textos para o material de divulgação ficou definido após a proposição do primeiro texto. O elemento norteador do processo teve origem na leitura do material levantado pela pesquisa documental, através desse, foi possível fazer uma revisão de diversos textos de Cafés pelo mundo. A maioria dos textos do material de divulgação desses eventos se apresentou através de perguntas provocativas, instigantes e até mesmo irônicas. Ao se basear nesse mesmo critério, os textos do Projeto Barômetro foram criados com uma pergunta principal mais abrangente seguida de perguntas menores, um pouco mais específicas. Outro critério foi adicionado a esse processo de elaboração e fez parte da construção da identidade do projeto. As perguntas, além de provocadoras, foram elaboradas fazendo uso da controvérsia.

Enunciados, termos e expressões típicos do discurso da Ciência foram utilizados como elemento confrontador em relação aos enunciados, termos e expressões típicos dos temas debatidos. A provocação ficou por conta da desconstrução dos discursos de ambas as áreas e pela elaboração de enunciados inesperados e questionadores. Os textos para divulgação dos oito primeiros programas de 2011 se encontram no Quadro 6 a seguir: 
Quadro 6 - Textos do material de divulgação dos programas do

"Barômetro" no ano de 2011

CAFÉ 1 - Ciência e Samba

A ciência dá samba?

Afinal, a ciência dá samba? O samba se ensina na escola? A ciência se aprende na vida? Venha bater um papo descontraído e discutir sobre essas e outras questões com um físico e um sambista da velha guarda do samba de Belo Horizonte no ritmo de um samba de breque.

\section{CAFÉ 2 - Ciência e Dengue}

Vamos combater a dengue?

Qual é o papel da Ciência no combate da Dengue? Qual é o impacto das estratégias de prevenção e controle? Qual é o papel da sociedade nesta luta? E você, sabe qual é a sua parte nesta batalha?

\section{CAFÉ 3 - Ciência e Arte}

Ciência e Arte, razão e emoção na mesma discussão?

Ciência e Arte já beberam na mesma fonte? Trilharam os mesmos caminhos? Obras na Ciência? Descobertas na Arte? Atingir a fruição através da experimentação? Buscar soluções pelas artimanhas da criatividade?

\section{CAFÉ 4 - Ciência e Design}

Química e Design, caminhando para a sustentabilidade?

Química verde? Design sustentável? A química instiga o design? O que nosso design tem de química?

\section{CAFÉ 5 - Ciência e Religião}

Ciência e Religião, criações culturais do homem em busca da totalidade?

O que dá sentido para vida, a capacidade do homem de se apossar do mundo ou de apossar-se de si mesmo? Controlar o mundo pela fé? Atribuir sentido através da razão? Ou o diálogo é possível?

CAFÉ 6 - Ciência e Sala de aula

Ciência e sala de aula

O lúdico no gostar de aprender? Há maior interesse na sala de aula de ciências no ensino fundamental? Onde está esse rompimento do gostar da ciência? Jogos de ciências ou amor pela escola?

\section{CAFÉ 7 - Ciência e Astrologia}

Escrito nas estrelas! Mudanças climáticas, desastres naturais ou conjunções planetárias?

Os fenômenos da natureza são decorrentes da ação do homem ou do posicionamento dos corpos celestes? Que previsões apresenta a ciência? Quais são as estimativas astrológicas? Adivinhações científicas ou previsões determinadas pelos astros?

\section{CAFÉ 8 - Ciência e Inclusão social}

Poesia e Inclusão

Acesso ou oportunidades? Ciência e poesia para novas formas de inclusão? Há teorias para inclusão? A rima pode promover uma nova distribuição? O que dizer de formas de experimentação e novas oportunidades de poesia para todos? Benefícios em camadas ou intervalos de inclusão?

Fonte: Elaborado pela autora. 


\section{A divulgação}

A divulgação dos eventos do projeto foi realizada através de diferentes mídias. A parte impressa ficou por conta da distribuição institucional interna e da distribuição em diversos equipamentos culturais externos à universidade. Para tal, foram elaborados cartazes e pop cards. Na noite de cada "Café", o pop card do próximo já estava disponível para o público participante.

A imprensa universitária registrou mês a mês os encontros. A equipe da rádio inseriu a divulgação dos eventos na sua programação.

A produção do projeto organizou um mailing list com os registros deixados pelo público participante no caderno de assinaturas. A comunicação com esse público foi mensal, inclusive no mês de julho, época em que não houve evento. $A$ equipe da Diretoria de Divulgação Científica da UFMG divulgou o convite eletrônico nas redes sociais. Os demais integrantes do projeto ficaram à vontade para fazer seus convites pessoais. Segue a relação dos percursos da divulgação:

- Divulgação institucional interna: jornais de circulação interna, cartazes e pop cards, divulgação eletrônica interna - demais setores da instituição;

- Divulgação institucional externa: mídia eletrônica, mídia impressa (cartazes e pop cards) - museus, escolas, bares, livrarias;

- Divulgação para público participante: mídia eletrônica/ mailing list;

- Divulgações pessoais da equipe de produção: mídia eletrônica, mídia impressa.

\section{Constituir a equipe de concepção e produção e os custos presumidos}

Para se colocar em prática um projeto como esse, foram necessários a mobilização e o envolvimento de uma equipe multidisciplinar. Da concepção e produção até 0 acontecimento dos programas, várias ações foram tomadas, promovendo o envolvimento de setores diversos da instituição e de prestadores de serviços externos a ela. Para tal, segue abaixo a relação de profissionais e setores engajados no projeto:

- Concepção: professora/doutora/física - Diretoria de Divulgação Científica da UFMG (1); 
- Produção: designer - doutoranda da Faculdade de Educação da UFMG (1);

- Identidade visual e desenvolvimento de material de divulgação: designers - CEDECOM/UFMG (3);

- Equipe de concepção e manutenção do software da Esfera Semântica: programador e engenheiro prestadores de serviços, contratação externa (2);

- Realização do programa: equipe rádio - mediação: coordenador e estudantes do curso de Comunicação Social (7)/ transmissão: técnicos da rádio e estudantes de cursos de Engenharia (4);

- Apresentações musicais: técnicos da CAC/UFMG (2);

- Transporte das equipes, dos materiais e dos convidados: motoristas da UFMG (2);

- Organização da Sala do Piano: designer e bolsistas do LEME/FaE/UFMG e da Diretoria de Divulgação Científica - DDC (3);

- Apoio na organização da Sala do Piano: técnicos administrativos e de manutenção do Centro Cultural UFMG (6);

- Apoio divulgação e parte institucional DDC/UFMG: técnicos administrativos DDC/UFMG (3).

A relação contabilizou uma equipe em torno de 34 profissionais de setores e ocupações variadas, que se mobilizaram mês a mês, para a realização de cada evento do "Barômetro". Como grande parte desses profissionais eram funcionários da instituição, suas participações implicaram um valor de custos presumidos de grande significância. Se a coordenação do projeto tivesse de contratar mensalmente esses profissionais, isso implicaria em valores e custos para a instituição. 


\subsubsection{Relação entre a tríade do "Barômetro" e os processos de design e instrução}

O Quadro 7 abaixo traz as relações entre a tríade do "Barômetro" e os processos do design instrucional que se referem ao design e à instrução. Para cada elemento da tríade, foram estabelecidas ações e metas que conferiram seu design e seus processos internos que o caracterizaram. O conjunto dessas ações e metas criaram os processos que conferiram o design do projeto "Barômetro" como um todo. O quadro representa uma síntese desses processos.

Quadro 7 - Relação — tríade do Barômetro x processos de design e instrução

\begin{tabular}{|c|c|}
\hline Conferência & Design - perfil dos debatedores \\
\hline & Instrução - procedimentos para os debatedores \\
\hline & Design - script \\
\hline $\begin{array}{l}\text { Programa de } \\
\text { Rádio }\end{array}$ & $\begin{array}{l}\text { Instrução - procedimentos de mediação/ procedimentos de } \\
\text { participação dos debatedores/ procedimentos de participação do } \\
\text { público/ procedimentos de participação dos músicos/ procedimentos } \\
\text { de participação virtual }\end{array}$ \\
\hline & Design - a esfera semântica, o tablet, a projeção \\
\hline $\begin{array}{l}\text { Intertace } \\
\text { Digital }\end{array}$ & $\begin{array}{l}\text { Instrução - procedimentos de manuseio do tablet, de elak } \\
\text { envio de perquntas ou comentários }\end{array}$ \\
\hline
\end{tabular}

Fonte: Elaborado pela autora. 


\section{COMUNICAÇÃO PÚBLICA DA CIÊNCIA}

Oportunidade bacana de poder observar a interação da academia, comunidade e arte de forma tão enriquecedora para todas as partes!

(Registro do caderno de opiniões Barômetro Ciência e Dengue - 14 de abril de 2011.)

A abordagem teórica expôs alguns posicionamentos de estudos sobre divulgação científica e tem, nos modelos de Comunicação Pública da Ciência de Lewestein (2003), seu ponto de maior interesse. A leitura de material pertinente ao assunto possibilitou a constatação de que, além de posicionamentos diversos sobre a atividade de divulgação científica por parte dos autores estudados, algumas concepções de vinte a trinta anos atrás são ainda citadas e consideradas. Devido a isso, veio a decisão de estabelecer um recorte temporal que coincidisse, em termos cronológicos, com o fenômeno dos Cafés Científicos (CC) mundo afora. Dessa forma, as concepções aqui apresentadas corresponderam a uma amostra de publicações dos últimos dez anos.

A leitura e a seleção dos autores listados no texto foram feitas no sentido de buscar no referencial teórico melhor entendimento dos processos e interações gerados nesses espaços. Esses propósitos não se centraram em somente compreender o funcionamento dos CC, mas compreender e conhecer um pouco mais de perto quem são os atores envolvidos nesse processo, de onde vem e, principalmente, sobre o que falam. De forma mais detalhada, saber quais são seus posicionamentos enunciativos, como abordaram as questões da ciência e segundo quais perspectivas.

Determinadas partes dos posicionamentos dos autores foram destacadas e comentadas ao longo do texto, de modo a explicitar indicadores, no referencial teórico, do processo de desenho e desenvolvimento desta pesquisa.

A primeira autora, Zamboni (2001), traçou um panorama geral a respeito da atividade de divulgação científica e dos desdobramentos dessa atividade. Essa autora entende a divulgação científica como uma atividade de difusão que dirige para fora do contexto original os conhecimentos científicos produzidos e circulantes no interior de uma comunidade de limites restritos. A veiculação das informações científicas e tecnológicas para o público em geral vai precisar da mobilização de diferentes recursos, técnicas e processos para que isso aconteça. A autora reconhece a difusão científica como um gênero que se desdobra nas espécies 
divulgação científica, disseminação científica e jornalismo científico.

Para ela, o conceito de difusão é extremamente amplo e abrange os periódicos especializados, os bancos de dados, os sistemas de informação dos institutos e centros de pesquisa, os serviços de alerta das bibliotecas, as reuniões científicas, as seções especializadas das publicações de caráter geral, as páginas de ciência e tecnologia de jornais e revistas, os programas de rádio e televisão dedicados ao tema, o cinema dito científico, os chamados colégios invisíveis, entre outros. Como pôde ser visto, a difusão científica é um conceito que compreende, para essa autora, duas abordagens, a primeira, a difusão para os especialistas, e a segunda, a difusão para o público em geral. A abordagem que diz respeito aos especialistas é considerada uma atividade de disseminação científica e a abordagem que diz respeito ao público em geral, uma atividade de divulgação científica. Das duas abordagens propostas, a divulgação científica especialmente interessa aos propósitos de pesquisa.

A divulgação científica geralmente inclui, para a autora, o jornalismo científico, as campanhas institucionais e governamentais de saúde e higiene, os fascículos de ciência e tecnologia produzidos pelas grandes editoras, os documentários, os programas temáticos de rádio e televisão. Ao longo de uma década, as atribuições dadas a essa atividade não ficaram, certamente, restritas às mídias aqui citadas.

Zamboni (2001, p. 48) destacou o peso que especialistas na área de comunicação atribuem à linguagem. Para a ela, a linguagem científica precisa ser "recodificada" e essa deve ser a tarefa mais árdua que caberá ao divulgador. Também não há, para a autora, a distinção entre popularização científica e divulgação científica e os respectivos termos correlatos em outros idiomas como o francês (vulgarisation scientifique), o inglês (popularizations ou science journalism) e o espanhol (periodismo científico). Toda ação que diz respeito ao ato de "fazer a ciência circular" proporcionando difusão de conhecimentos científicos e tecnológicos, cujo alvo é o sujeito de fora da esfera científica, a autora considera uma atividade de divulgação científica.

A tarefa primeira da divulgação científica, ela acredita, é a de promover a partilha social do saber ao levar, para o sujeito de fora da esfera científica, o conhecimento do qual ele foi historicamente apartado e, do qual, mantém-se cada vez mais distanciado. Outra tarefa, também essencial, é a função educativa que cria a oportunidade de contribuir para a formação da opinião pública com 
posicionamento mais crítico e, consequentemente, menos alienado. Embora a autora coloque a função educativa dessa maneira, esse fato não significou que ela realmente forme a opinião pública com posicionamento crítico ou que ela simplesmente passe a informação adiante. Cazelli (2000), apresentada no texto pouco à frente, fez uma crítica a esse processo de comunicação.

A produção científica ganhou a mediação de um vulgarizador na concepção de Zamboni (2001). A pesquisa realizada nos sites dos Cafés Científicos levantou o uso do termo "comunicador" pelos seus organizadores, termo esse que foi utilizado no decorrer deste trabalho. Nascimento e Ventura (2001), em suas proposições sobre a concepção de um museu de ciências interativo, também sugeriram a presença de um comunicador, em suas palavras, um "comunicólogo", especialista das modernas técnicas de comunicação e design, que busque a síntese dos conhecimentos científicos e promova a discussão junto ao público.

Zamboni (2001) tocou em três pontos que encontraram nas concepções dos eventos de CC elementos de interesse. Em primeiro lugar, a mobilização de recursos, técnicas e processos, em segundo lugar, o peso atribuído à linguagem científica, que precisa ser recodificada e, em terceiro, a promoção da partilha social do saber. Esses pontos, por assim dizer, constituem as bases para 0 desenvolvimento e a promoção dos CC ao redor do mundo e estão no cerne das preocupações dos diversos profissionais envolvidos em suas concepções.

A autora que se segue, Cazelli (2000), discorreu sobre diferentes categorias de divulgação científica e a qualidade do que resulta dessas atividades para aqueles que a recebem.

Barros (1992, p. 62-64), citado por Cazelli (2000, p. 10), definiu cinco categorias de divulgação científica, são elas a divulgação utilitária, a divulgação do método, a divulgação dos impactos, a divulgação dos avanços e a divulgação cultural. A divulgação utilitária está associada às aplicações da ciência; a divulgação do método aborda os processos científicos sem criticá-los; a divulgação dos impactos se relaciona às novas descobertas e suas aplicações; a divulgação dos avanços coloca a ciência como um processo de informações onde o progresso representa uma continuidade; e, por último, a divulgação cultural onde a ciência se posiciona como elemento central a partir do qual se abordará a cultura. Para essa autora, essas categorias não são excludentes, isto é, uma pode conter elementos das outras. As quatro primeiras possuem um ponto em comum que é o objetivo de 
divulgação diretamente ligado à produção científica, ao aceitarem a ciência como um conhecimento universal e procurarem uma linguagem simplificada para torná-la popular. A quinta se difere das anteriores, pois coloca a cultura subordinada à ótica da ciência.

Em relação à qualidade da divulgação científica contemporânea, Cazelli (2000) estabeleceu uma posição crítica. Para a autora, as informações científicas divulgadas pelos meios de comunicação são geralmente fragmentadas e sem nenhum tipo de preocupação quanto à sua origem. Os atributos e adjetivos científicos são comuns de serem encontrados em textos, termos ou siglas esvaziados do conteúdo da ciência que representam. Tornou-se necessário que houvesse uma negociação entre o discurso da ciência e o discurso da mídia na fala dos jornalistas. Os veículos de comunicação, televisão, internet, rádio, jornais, livros, revistas ou mesmo os espaços não formais de educação em ciências utilizam da encenação para seduzir o consumidor por determinado período de tempo.

Cazelli (2000) entendeu a atividade de divulgação científica como um processo de recodificação do discurso científico que não está restrito ao campo da imprensa, mas em uma concepção mais ampla, deve estar presente nas diversas práticas sociais de educação científica e tecnológica. Estão incluídos nessas práticas os espaços formais de educação e os contextos externos a eles. A autora ressaltou que é interessante diferenciar as práticas de uso corrente nas escolas das disponibilizadas pelas atividades da divulgação científica, ou seja, da comunicação pública da ciência. A principal diferenciação está na possibilidade da ocorrência de práticas que utilizem como recursos outros que não os habituais do espaço escolar.

Se a divulgação científica tem como tarefa primordial o objetivo de familiarizar os sujeitos de fora dela com os conhecimentos gerados por ela e suas implicações, a sociedade enfrenta outra realidade. A discussão em torno da aspiração da sociedade para adquirir melhor entendimento da ciência, sua imagem pública e seus processos internos, recaiu no debate sobre o que os sujeitos de fora da ciência sabem ou deveriam saber sobre ela. Segundo Cazelli (2000), os dados alarmantes foram constatados ainda nos anos de 1970 baseados em pesquisas de opinião pública, onde os cientistas não apenas estavam perdendo o status privilegiado, como a confiança pública na ciência e nas instituições científicas declinava rigorosamente. Além disso, outra constatação revelou baixos níveis de compreensão sobre os conhecimentos gerados pelo empreendimento científico. Para a autora, é 
inevitável não questionar por que cresce a ignorância pública sobre a ciência e a tecnologia, se as sociedades de hoje são praticamente, em sua maioria, ligadas à vida urbana. Ela se perguntou sobre quais seriam as soluções que a sociedade vem apresentando para ampliar sua própria noção sobre o que seja ciência, se a mesma contribui para o conhecimento, é criada pelos indivíduos da sociedade, é pública, determinada e moldada pelas relações sociais entre esses indivíduos.

As informações científicas fragmentadas de que falou a autora, acompanhadas pelos processos de negociação entre o discurso da ciência e 0 discurso da mídia reforçam o peso sobre a linguagem citado por Zamboni (2001). Ambas as autoras consideraram a recodificação do discurso científico e a elaboração de novas práticas sociais para a educação e comunicação do conhecimento científico. E esse também é um dos tópicos abordados por Lewestein (2003) na explanação sobre seus modelos. Cazelli (2000) sustentou ainda que os recursos utilizados não seriam os mesmos habituais do espaço escolar e inverteu o processo de divulgação científica ao questionar sobre o que a sociedade sabe ou deveria saber sobre ciência.

As conclusões da pesquisa sobre Percepção Pública da Ciência e Tecnologia realizada no fim do ano de 2006, com cerca de mais de 2000 mil pessoas em todo 0 país pelo Ministério da Ciência e Tecnologia, ilustraram a situação no Brasil. Embora $41 \%$ dos entrevistados consideraram que o país ocupe uma posição intermediária no cenário mundial no que tange ciência e tecnologia e que a ciência brasileira tenha avançado em relação à produção internacional, os resultados sobre o interesse do público revelaram outra realidade. Os assuntos da ciência despertaram $41 \%$ da preferência do público, mas perderam para a medicina e saúde $(60 \%)$, o meio ambiente $(58 \%)$, a religião (57\%), a economia (51\%) e os esportes (47\%). A ciência ficou à frente da política que não passou dos $20 \%$.

O baixo interesse foi explicado na pesquisa através de outros dados extremamente interessantes para este estudo: $37 \%$ dos entrevistados afirmaram não entender sobre os assuntos da ciência e 14\% afirmaram não gostar dos assuntos abordados. Os meios principais de informação sobre ciência e tecnologia apresentaram baixo índice de assiduidade por parte do público. Para a categoria de acesso aos meios de informação "sim, com frequência" apenas $15 \%$ admitiram assistir programas de televisão sobre ciência e tecnologia, $5 \%$ ouvir programas de rádio, $12 \%$ ler sobre ciência nos jornais, outros $12 \%$ ler revistas especializadas, $9 \%$ 
buscar informações na internet, $11 \%$ conversar com amigos sobre o assunto e $2 \%$ participar de manifestos e manifestações que envolvem interesses relacionados ao tema. Mesmo assim, 46\% dos entrevistados consideraram que a ciência e a tecnologia trazem mais benefícios do que malefícios para a sociedade.

Os resultados e análises dessa pesquisa chamaram a atenção para a forma como seus dados foram relacionados e analisados. Nos dados que se referem ao tópico "assuntos", não foram estabelecidas relações entre ciência, medicina e saúde, meio ambiente e economia, por exemplo. A ciência apareceu como um fato isolado que não se integrou aos demais assuntos apresentados. Os assuntos medicina, saúde, meio ambiente, principalmente, fazem parte da esfera da ciência e vice e versa.

Resultados e análises a parte, a pesquisa ilustrou, de certa forma, os modelos formulados por Lewenstein (2003), autor que se segue, e que propôs uma espécie de agrupamento para as diferentes atividades e formas de divulgação científica, apontados pelos autores até então.

O trabalho de Lewenstein (2003) mostrou uma abordagem interessante para entender como as diferentes perspectivas da comunicação pública da ciência e da tecnologia podem conduzir atividades e empreendimentos diferentes. Sua intenção foi a de compreender as motivações, as forças e os desafios associados a essas abordagens diferenciadas.

Para esse autor, a trajetória da comunicação pública da ciência nos últimos quinze anos correspondeu ao esforço vigoroso de jornalistas, cientistas, curadores de museus, entre outros, de enxergarem a comunicação pública como o uso apropriado de recursos de tempo e dinheiro. Mas se todo esse empenho tem alcançado sucesso, para ele, isso não é tão claro. Em parte, é porque não existe consenso sobre seu objetivo, sobre o que realmente constitui melhorar a comunicação pública da ciência. Para quase todas as atividades organizadas para promover o entendimento público que estão em andamento, os acadêmicos de diferentes disciplinas exploraram o que significa "entendimento público", quais são os objetivos das diferentes atividades de comunicação pública, quem está sendo considerado e quem não está e quais constrangimentos afetam o entendimento público da ciência.

Lewenstein (2003) propôs quatro modelos de comunicação pública da ciência: o modelo déficit, o modelo contextual, o modelo de experiência leiga e o modelo de 
participação pública. Para explicar o modelo déficit, o autor enfatizou que a maioria das discussões sobre o entendimento público da ciência emerge da própria comunidade científica. A preocupação principal tem sido, desde meados do século XIX, a falta de suporte público intelectual para os caminhos do pensamento científico e de suporte público material para o trabalho científico, ou seja, os fundos para pesquisa. Uma pesquisa realizada pelo National Science Board tentou medir o conhecimento público dos americanos e suas atitudes em relação à ciência e tecnologia. Apenas 10\% dos entrevistados sabiam definir "molécula" e mais da metade acreditavam que humanos e dinossauros viveram na Terra ao mesmo tempo. A combinação dessas questões factuais com outras sobre processos da ciência e o lugar institucional da ciência evidenciaram medidas de "alfabetização científica" que mostraram, dependendo do ano e do método de interpretação, que apenas $20 \%$ eram interessados e informados. O resto, por definição, é residual. Esses tipos de estudos fizeram com que a comunidade científica lidasse com a falta de conhecimento e criasse novos programas para fornecer informações que suprissem essa falta de conhecimento. Essa abordagem ficou conhecida como o "modelo déficit", a partir do pressuposto de que ele descreve um déficit de conhecimento que deve ser preenchido, com a presunção de que depois que esse déficit for "consertado", tudo ficará "melhor". Projetos direcionados para a alfabetização científica surgiram nos Estados Unidos da América do Norte diretamente relacionados aos interesses nacionais de inovação tecnológica e desenvolvimento econômico, assim como aconteceram revisões curriculares em outros países.

Porém, os acadêmicos identificaram uma série de dificuldades com o modelo déficit. Mais notavelmente pelo fato que muitas questões foram realizadas sem considerar o contexto. Teorias da aprendizagem mostraram que as pessoas aprendem melhor quando fatos e teorias estabelecem algum tipo de significado com suas vidas pessoais. Pouca atenção tem sido dada a outras formas de conhecimento que são relevantes para os indivíduos em suas vidas diárias. Outra crítica dessa abordagem residiu no seguinte fato, após 25 anos de ações e tentativas de excelência em torno do entendimento público da ciência, os números permaneceram os mesmos.

Como resultados dessas preocupações pelo menos três outros modelos, se desenvolveram em resposta a esse. Esses modelos formaram a estrutura para o 
entendimento sobre o que é "o problema", como "medi-lo" e como "direcioná-lo".

O modelo contextual reconheceu que os indivíduos simplesmente não respondem como "embalagens vazias" de informação, mas processam as informações de acordo com estruturas sociais e psicológicas que formataram suas experiências prévias, seu contexto cultural e suas circunstâncias culturais. Modelos contextuais reconhecem que os indivíduos recebem informações em contextos particulares, os quais vão configurar como eles irão responder a essas informações. Aspectos psicológicos pessoais podem afetar o contexto como o medo, a agressividade, assim como o contexto social em que a informação é recebida. Esses modelos também reconhecem a habilidade dos sistemas sociais e das representações da mídia tanto para abafar como para ampliar as preocupações públicas sobre temas específicos. Novas abordagens de modelos contextuais têm utilizado abordagens de segmentação de mercado modernas para identificar populações com diferentes atitudes em relação à ciência, sem necessariamente atrelar esses grupos em contextos particulares de risco ou níveis de "alfabetização científica". Em termos práticos, um modelo contextual fornece os direcionamentos para a construção de mensagens sobre ciência relevantes para indivíduos em contextos particulares.

Essa abordagem dos modelos contextuais tem sofrido críticas por ser simplesmente considerada uma versão sofisticada do modelo déficit: existe o reconhecimento de que as audiências não são navios vazios, mas que, entretanto, conceituam um problema no qual os indivíduos respondem às informações de forma que parecem inapropriadas para os especialistas científicos. O uso recente do marketing e das abordagens demográficas aumentaram a preocupação de que a pesquisa do modelo contextual é pretendida como uma ferramenta de manipulação de mensagens para atingir alvos particulares, o objetivo não é o "entendimento", mas a "concordância".

Em resposta aos modelos de déficit e contextual, os pesquisadores expressaram a preocupação de que as perspectivas para explorar a comunicação pública da ciência e da tecnologia estavam muito ligadas aos interesses da comunidade científica, o que, quase por definição, constituiu um grupo de elite na sociedade. Esses modelos geralmente parecem igualar "entendimento público da ciência" com "apreciação pública dos benefícios oferecidos pela ciência para a sociedade". Eles não direcionavam adequadamente os contextos sociais e políticos 
através dos quais as instituições poderosas da ciência fazem uso da "alfabetização científica" como ferramenta retórica para influenciar fundos e decisões políticas, algumas vezes em oposição política ao trabalho e aos interesses locais.

$\mathrm{Na}$ metade dos anos de 1980, esses pesquisadores enfatizaram a importância do reconhecimento dos saberes locais e do comprometimento para uma política de inclusão e participação. Dessas preocupações, emergiram dois modelos: o de experiência leiga e o de participação pública.

O modelo de experiência leiga começou com o conhecimento local, algumas vezes chamado de "conhecimento leigo". Esse conhecimento se baseou nas histórias reais das comunidades. Seu argumento principal foi o de que os cientistas estão excessivamente certos, mesmo arrogantes, sobre seus níveis de conhecimento, falham ao reconhecer as contingências ou informações necessárias para tornar o mundo real pessoal ou uma política de decisões. Embora alguns pesquisadores considerem esse modelo um tópico do modelo de contextualização, Lewenstein (2003) assumiu a posição de que ele possa se distinguir. Ao contrário de modelos contextuais que compreendem 0 valor do conhecimento, embora reconheçam a complexidade da distribuição, o modelo de experiência leiga entende que o conhecimento local deve ser tão levado em conta quanto a resolução de problemas, como é o caso do conhecimento técnico. Com análises baseadas em estudos de casos, os proponentes desse modelo afirmaram que as atividades de comunicação precisam se estruturar em meios onde o reconhecimento da informação do conhecimento e da experiência já tenha sido apropriado por comunidades que lidam com as questões científicas e técnicas.

Assim como os outros, esse modelo também está sujeito a críticas. Em particular, ele privilegia o conhecimento local acima do conhecimento seguro sobre 0 mundo natural produzido pelo sistema científico moderno. Por essa razão, esse modelo pode ser chamado de "anticiência" e, certamente, alguns de seus proponentes tem sido alvo de algumas disputas rancorosas das "guerras das ciências" da década de 1990. Especialistas científicos existem porque o conhecimento é difícil de obter e manter. O modelo de experiência leiga é claramente impulsionado pelo comprometimento político para fortalecer as comunidades locais. Isso também não esclareceu como um modelo de entendimento público baseado na experiência leiga forneceu orientações para atividades práticas que pudessem intensificar o entendimento público de tópicos particulares. Esse 
aspecto sugeriu que atividades delineadas para intensificar a confiança entre os participantes em uma disputa política possuem maior apreço do que específicas abordagens educacionais ou informacionais.

Justamente devido à importância da confiança social como um aspecto das disputas políticas sobre as questões científicas e técnicas que um modelo de "participação pública" ou "engajamento público" emergiu com foco em uma série de atividades para intensificar a participação pública e a confiança na política da ciência. Tais atividades incluíram conferências de consenso, júris de cidadãos, contribuições tecnológicas deliberativas, lojas de ciência, votações deliberativas e outras técnicas. As atividades de participação pública poderiam ser impulsionadas pelo compromisso com a "democratização" da ciência, se tirar o controle da ciência da elite de cientistas e políticos e entregá-lo aos grupos públicos através de alguma forma de fortalecimento e engajamento político.

Tanto esse modelo quanto o modelo de experiência leiga, devido aos seus comprometimentos com posicionamentos particulares que envolvem relações políticas, podem ser criticados por seus direcionamentos políticos e não pelo entendimento público. Outra crítica está no seu foco, que é o processo da ciência e não seu conteúdo, fato que atinge um pequeno número de pessoas e em alguns casos tem uma tendência para a "anticiência".

Para Lewenstein (2003), esses modelos fornecem somente uma ferramenta esquemática para a compreensão das atividades de comunicação pública da ciência. Na prática, muitas dessas atividades combinam elementos dos quatro modelos. Uma tarefa considerável para o autor é a de, mais adiante, refinar os modelos através do entendimento das relações entre as visões idealizadas sobre o que as atividades de "entendimento público da ciência" devem ser e o que elas realmente são. Uma das necessidades imediatas é a de expandir a visão sobre como os projetos de comunicação podem ser pensados e entender como esses projetos pensados se relacionam com os já existentes. Um exemplo claro talvez seja a proliferação de projetos "cidadão/ciência", nos quais estudantes e amadores podem se engajar profundamente em fornecimento de dados, tanto para a comunidade científica profissional quanto para seu próprio uso. Esses projetos combinam educação, pesquisa e certo grau de entretenimento. Mas esses projetos são tentativas de preencher o déficit e criar a participação pública na ciência? Eles ajudam as pessoas ao trazerem o conhecimento local na busca de soluções locais? 
O autor respondeu, seguramente, que sim. Mas os modelos de comunicação pública da ciência não se dirigem a esses múltiplos e sobrepostos objetivos.

Lewenstein (2003) considerou ainda outra tarefa que tem a linguagem como elemento central. A ênfase recente do "engajamento público" na linguagem dos pesquisadores e dos designers de projetos gerou a necessidade de melhor entendimento por parte da sociedade sobre o que essa linguagem quer dizer. Variados tipos de engajamento podem ser enfrentados, eles podem ser individuais, direcionados a grupos determinados ou se configurarem como uma atividade pública. Para o engajamento dos grupos ou públicos uma lista de "elementos de engajamento" deve ser mensurada ou observada e deve incluir o tamanho dos grupos, o número de pessoas envolvidas, o grau de deliberação que os grupos oferecem, a existência de forças e atitudes expressas pelos grupos, as habilidades para agir.

O autor afirmou que uma lista de direcionamentos futuros pode se expandir e chegou a uma conclusão, a constatação da necessidade de mais pesquisas sobre comunicação pública da ciência e da tecnologia. É imprescindível melhor entendimento sobre objetivos e realizações de tipos particulares de atividades de comunicação pública. $O$ entendimento pode ser alcançado, em parte, pelo reconhecimento de que os modelos descritos estejam no trabalho de quaisquer projetos particulares de comunicação pública e naqueles em que a atividade de comunicação pública da ciência não se ajuste a esses modelos.

A principal contribuição de Lewestein (2003) para esta pesquisa residiu no dinamismo que iniciativas e projetos na área de comunicação pública da ciência podem assumir ao não procurar o enquadramento dentro de seus modelos, mas propor justamente o contrário. A flexibilização é necessária para a aproximação desses mundos aparentemente tão distantes, ciência e sociedade.

A autora que se segue, Monteiro (2006), levantou uma perspectiva até então não considerada, que é a oportunidade do diálogo em rede promovido pelas tecnologias de informação. Ela considerou também o posicionamento político através de uma sociedade, a seu ver, não somente observadora passiva das recentes descobertas científicas.

Monteiro (2006) incorporou ao cenário desse debate outro aspecto interessante que são as modernas tecnologias de informação e comunicação. Em suas palavras, essas tecnologias ampliaram em proporções incomensuráveis as 
possibilidades de diálogo entre os participantes das comunidades científicas e incluíram nessa conversa outros atores. $\mathrm{O}$ advento das novas tecnologias promoveu um rompimento de fronteiras que abriu as comportas da produção da ciência e da tecnologia à participação da sociedade. Segundo a autora, a sociedade hoje cobra dos cientistas maior responsabilidade social em relação ao impacto do que produzem e publicam. Isso levou a comunidade científica à prática da legitimação de suas atividades junto a outros grupos sociais e não somente a seus pares. As instâncias da produção do conhecimento ganharam uma dimensão política que acarretaram um processo contínuo de negociações, mediações, consultas e contestações em diversos espaços institucionais e ganharam visibilidade nas esferas das arenas públicas.

A autora explicou que as arenas públicas são os "lugares" de confrontação simbólica onde os problemas públicos são formulados e amplificados segundo regras previamente definidas. Esses "lugares" incluem as instâncias executivas e legislativas do governo, os tribunais, os filmes de televisão e cinema, a mídia, as organizações de campanhas políticas, os grupos de ação social, as solicitações através de mala direta, os livros que tratam as questões sociais, as comunidades de pesquisa, as organizações religiosas, as sociedades profissionais e as fundações privadas.

A ênfase do trabalho de Monteiro (2006) se centrou no lugar privilegiado ocupado pela imprensa. Segundo a autora, a imprensa tem sido mobilizada pela ciência e, através desse processo, os cientistas e suas instituições acabaram por se inserir no espaço público em busca de integrar a ciência ao cotidiano do público.

A ciência que vem há tempos "falando" para a sociedade se deparou, na atualidade, com a sociedade também "falando" com a ciência. Tal movimento no sentido inverso está transformando a ciência que passou a ter de ouvir a sociedade. A contextualização do conhecimento passou a se fundamentar não somente na sua aplicação, mas na sua implicação.

O conhecimento produzido nesse espaço social em transformação é mais rico, mais confiável e se encontra sujeito tanto às controvérsias do campo científico, quanto à própria contestação pública da ciência. A negociação e renegociação de demandas e desejos produziram nova forma de contextualização do conhecimento científico, em que a ciência e os cientistas são colocados frente a frente com múltiplos públicos e instituições que defendem, segundo a autora, vigorosamente seus interesses. 
Ao voltar o olhar para os contextos dos Cafés Científicos, seguem informações a respeito de uma pesquisa documental realizada nos artigos do periódico International Journal of Communication, o JWCOM, na busca de material para o desenvolvimento dessa pesquisa. Foram encontrados ao todo dez artigos, através dos termos "Science Cafe" e "Café Scientifique". A esperança de encontrar publicações que fossem além das informações redigidas na contextualização histórica acabou na constatação de que, mais uma vez, o que se divulga sobre Cafés Científicos correspondem às suas proposições, ao que os projetos que se desenvolveram em torno da ideia original têm para oferecer. Outras buscas foram realizadas e novamente foram encontrados relatórios de eventos de Cafés com informações básicas como número de participantes, temas debatidos, debatedores, entre outros. Até o presente momento não foram encontradas pesquisas que abordam o desenrolar dos acontecimentos, as discussões, o calor do debate. Um dos artigos chamou a atenção não somente porque tratava o tema, mas o tratava por meio de uma experiência recente de comunicação pública da ciência em uma grande potência econômica, o Japão.

O programa de estágios internacionais oferecido pelo Tokyo Institut of Technology, criado em 2005, apresentou uma concepção a respeito do que pode ser, hoje, a atividade de comunicação científica. No Japão, o reconhecimento do domínio público em relação à importância da comunicação da ciência é recente, fato que marcou o ano de 2005 como o "Inaugural Year of Science Communication" (O ano inaugural da comunicação em ciência). A comunicação da ciência é uma atividade na qual pessoas das mais variadas origens podem interagir através de meios diversos como, por exemplo, o diálogo. Para a equipe do programa, a ênfase mais recente reside no esforço coletivo para o engajamento dos cidadãos, direta ou indiretamente, com o objetivo de estimular interações entre as aspirações e necessidades da sociedade e as possibilidades e limitações da ciência. Outro aspecto da comunicação da ciência é o de permitir que os cidadãos comuniquem suas necessidades e valores dos seus próprios pontos de vista.

O programa sugeriu o que foi chamado de "duas camadas do design da comunicação da ciência". Para tal, foi preciso caracterizar o que seria essencial em termos de comunicação da ciência. Três pontos foram levantados: primeiro, que os tópicos a serem discutidos se restrinjam aos relacionados à ciência e à tecnologia; segundo, que as interações devem acontecer entre os que possuem pouco 
conhecimento da ciência e os que possuem mais; terceiro e último, que deve existir distribuições de papéis entre os participantes. Dessa maneira, as duas camadas se dividem em, primeiro, compreender a formatação feita antes do evento e teve como ponto de partida a posição dos organizadores da interação, o que incluiu a preparação do papel do facilitador. A segunda, compreender diversas estratégias e habilidades de cada um dos participantes. As atividades incluíram um estágio, o planejamento e a organização de um Café Científico ou a criação de conteúdos de imagens e manuscritos que introduzissem a ciência de forma geral.

O projeto de pesquisa aqui proposto também possui como objetivo para sua realização a concepção de Cafés Científicos cujas diretrizes coincidem em alguns pontos com as descritas acima. No decorrer do texto, posicionamentos interessantes dos autores também foram pontuados de modo a compor o conjunto de direcionamentos para a construção das questões de pesquisa.

A concepção do Café Científico que se transformou em objeto de pesquisa, o "Barômetro", atentou-se às premissas, às lacunas e aos questionamentos colocados pelos autores. Dentre eles, pode-se considerar como elemento comum a recodificação da linguagem científica, que acabou por adentrar nas esferas das negociações, seja da comunidade científica, seja da mídia de forma geral, seja da sociedade como um todo. Abordar as dificuldades com a linguagem já é um ponto de partida essencial para se promover a partilha social do saber e a inserção dos cidadãos como promotores do diálogo e da atitude política. Todo esse processo de mudanças exigiu mobilização para a criação de novos recursos e técnicas que pudessem garantir abordagens diferenciadas à comunicação pública da ciência. A importância das concepções dos autores foi a de enxergar esse processo de diálogo aparentemente inexistente e difícil como possibilidades de trocas dinâmicas e flexíveis.

Embora as colocações dos autores tenham colaborado nesse momento, uma lacuna ainda ficou sem ser fechada. Se as possibilidades existem, se os cidadãos de posse das ferramentas do mundo da informação passam a ter mais atitude política, se os próprios cientistas estão se sentindo na berlinda, então como se dá esse encontro? Como se dá o desenrolar dos acontecimentos?

Antes de concluir, é necessário pontuar algumas reflexões finais. As atribuições esfera científica, sujeito de fora da esfera científica, contexto original, entre outras, geraram a necessidade do estabelecimento de termos que pudessem 
caracterizar sobre quem estamos falando e como foi a abordagem nesse processo de pesquisa. Aqui ficaram estabelecidos os termos comunidade científica e sociedade civil.

Existiu a concordância de que as interações devem ocorrer entre os que possuem pouco conhecimento da ciência e os que possuem mais e que deve haver distribuições de papéis entre os participantes. Mas os assuntos debatidos não se restringiram à esfera científica, pelo contrário, estabeleceram relações entre a ciência e outras esferas do conhecimento. Esse ponto de diferenciação foi que deu uma característica especial à concepção do evento e que deu o direcionamento dos questionamentos aqui propostos.

O capítulo que se segue traz a construção do conceito de Dispositivos Pedagógicos Multimodais, conceito esse desenvolvido e proposto nesta tese. $\mathrm{O}$ conceito caracterizou e nomeou o contexto criado para as interações do "Barômetro - Ciência, café e debate". 


\section{DISPOSITIVOS PEDAGÓGICOS MULTIMODAIS - CONSTRUIR UM CONCEITO}

O projeto propicia as mais variadas formas de interação, escrita, falada e por participantes bem heterogêneos. Uma rica diversidade!

(Registro do caderno de opiniões Barômetro Ciência e Dengue - 14 de abril de 2011.)

A proposta de construção do conceito de Dispositivos Pedagógicos Multimodais veio após um ano e meio do projeto em andamento, após 12 programas colocados no ar (FOTO 3). A demanda surgiu da equipe da rádio institucional que sentiu necessidade de não somente caracterizar e entender o evento que eles transmitiam, mas de nomear aquele contexto inusitado onde ocorriam as interações.

Foto 3 - Visão geral da Sala do Piano, Centro Cultural UFMG, Barômetro - Ciência e Sala de Aula

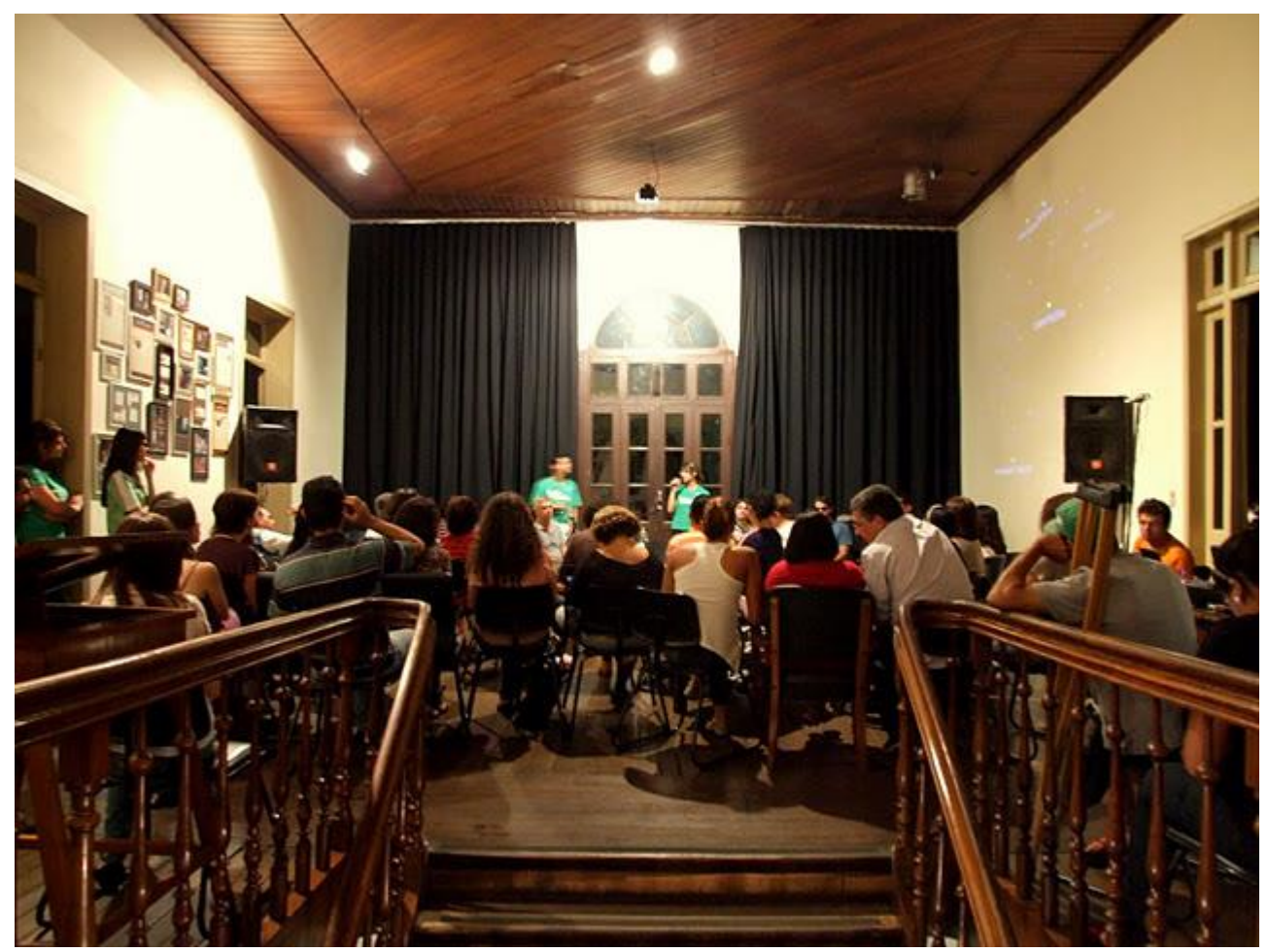

Fonte:VENTURA, 29 set. 2011.

A solicitação inicial foi a de que o conjunto de fatos ocorridos naquele contexto fosse descrito em um parágrafo e que ele tivesse um nome - o que era aquilo? Um dispositivo pedagógico, com certeza. Esse era o ponto de partida da equipe do projeto. Mas não era um dispositivo pedagógico qualquer, estavam ali reunidos elementos diversos que as pessoas que dele participavam comentavam nunca ter visto em lugar algum. 
Debater sobre ciência e temas inesperados, escutar boa música, cantar, dançar, servir-se no buffet, escolher palavras, manusear tablets, elaborar perguntas, trocar ideias, conversar, observar as perguntas aparecerem na projeção, admirar a projeção da esfera semântica, manifestar-se timidamente quando a pergunta elaborada era escolhida pelas repórteres da rádio, perguntar ao microfone, transitar de um lado para o outro, saber o que pensam as pessoas que não estavam presentes no local, pessoas em outros estados, em outros países, testemunhar estudantes em formação aprendendo na prática suas futuras profissões e ver de perto o funcionamento de uma transmissão em tempo real. Aquilo era um dispositivo pedagógico inovado pelos recursos da multimodalidade.

A construção do conceito partiu da definição dos termos multimodalidade e multimídia com objetivo de compreender melhor seus significados e, a partir deles, caracterizar com melhor precisão os ambientes multimodais. Depois, o conceito de dispositivos pedagógicos de Bernstein (1990) foi retomado com destaque para suas três regras. Logo após, foi realizado o levantamento da dimensão multimodal do "Barômetro" e as regras da multimodalidade foram elaboradas. Por fim, o conceito foi apresentado de forma sucinta, em um parágrafo.

\subsection{Os termos multimodalidade e multimídia}

Para se definir ou demarcar definições a respeito dos termos multimodalidade e multimídia foi necessário, primeiramente, compreender o que significam modalidade e mídia. $O$ entendimento desses termos foi fator fundamental para a compreensão e a elaboração do conceito de Dispositivo Pedagógico Multimodal que se pretendeu desenvolver.

A palavra modalidade é descrita no dicionário como maneira de ser, cada aspecto ou particularidade diferente em relação ao mesmo fato. Mídia, por sua vez, trata-se de qualquer suporte de difusão de informações que constitua ao mesmo tempo um meio de expressão e um intermediário capaz de transmitir uma mensagem a um determinado grupo.

Do ponto de vista acadêmico, encontra-se na concepção de Lauer (2009) proposições que tem como base o campo da semiótica. Segundo essa autora, modalidade se refere às formas de representar as informações ou os canais semióticos utilizados para se compor um texto, que incluem palavras, sons, imagens 
estáticas ou em movimento, animação e cor. Mídia se refere às ferramentas e fontes materiais utilizados para se divulgar textos, que incluem livros, rádio, televisão, computadores, vozes humanas, entre outros.

Lauer (2009) relatou que o termo multimodalidade, do inglês "multimodal", foi cunhado por membros do New London Group que incluem Cope e Kalantzis (2000), Kress $(2003,2005)$ e Kress e Van Leeuwen (2001). Para esses acadêmicos, a comunicação não se limita a apenas a uma modalidade, tal como o texto, realizada através de uma mídia, tal como o livro. Como resultado da era da digitalização, todas as modalidades podem agora ser realizadas através de um simples código binário onde a tela se transformou no local principal, no qual, múltiplas modalidades podem se combinar para produzir significados de maneira dinâmica. Essas modalidades podem ser operadas por uma pessoa multi-habilidosa que faz uso de uma interface, de uma forma física de manipulação. Com interesse particular na produção de textos, os autores citados consideram que os meios de comunicação abriram possibilidades para que a produção textual seja não linear, hipertextual, continuamente revisada e interativa.

Lauer (2009) relatou também que o termo multimídia foi primeiramente utilizado para descrever a expansão das práticas de composição de textos nos espaços acadêmicos. Esse termo foi empregado com certa frequência nos anos de 1990 com o advento do CD-ROM para descrever textos elaborados através do computador que integravam palavras e imagens, sons e vídeo. No início dos anos de 1990, o termo foi entendido como a integração de duas ou mais mídias de comunicação. Textos e sons, imagens estáticas ou em movimento, desde que utilizadas para convencer ideias, vender produtos, educar ou entreter. A autora considera que as mídias de comunicação colocadas nessa definição, hoje, devem ser consideradas modalidades. Para ela, a última parte da definição dá ênfase ao produto acabado e à intenção por trás da utilização do produto, o que é mais característico do termo multimídia e seu emprego na indústria, do que multimodal e seu emprego na sala de aula, por exemplo.

Neste ponto do processo de construção do conceito que aqui se pretendeu propor, foi preciso levar em conta questões relacionadas ao design do contexto, do ambiente ou do dispositivo, e do que o caracterizou como multimodal.

Considerações sobre design já foram levantadas no Capítulo 3, que relatou o processo de concepção do dispositivo do projeto "Barômetro - Ciência, café e 
debate", segundo as proposições do design instrucional (DI). Em resumo, as proposições sobre DI relacionavam o design aos objetivos pretendidos, às formas de atingir esses objetivos e de saber como se alcançou os objetivos almejados. De certa forma, essas etapas foram contempladas no decorrer do processo de implantação e funcionamento do dispositivo e possuem forte elo com a regra avaliativa proposta por Bernstein (1990).

Kress (2004) colocou o design como a questão central em panoramas de comunicação multimodal. Embora ele tenha como foco processos e ambientes de composição de textos e formas diversas de interagir sobre eles, seus posicionamentos ajudaram nesse processo de construção. Para ele, se existem várias formas de expressar e modelar sua mensagem, algumas questões 0 confrontam: qual modalidade é a melhor, mais adequada de acordo com o conteúdo/ significado que ele deseja comunicar? Qual modalidade mais chama a atenção da audiência para a qual eu me dirijo? Qual modalidade corresponde com meus próprios interesses para modelar a mensagem para a comunicação? Qual mídia minha audiência prefere? Como me posicionar se escolho determinada mídia em detrimento de outras? Ele afirmou que tudo isso implica em escolhas que irão apoiar sua avaliação do ambiente no qual a comunicação acontece, em toda sua complexidade, em seu sentido mais amplo no qual a conveniência é todas as "mensagens" para interpretar. Design, para Kress (2004), é um empreendimento de longo prazo.

A relação entre os posicionamentos de Kress (2004) e os procedimentos tomados para a construção do dispositivo do "Barômetro" foi de extrema afinidade e demonstrou, como nesse caso, pode ser tênue e dinâmica a fronteira entre o ato de conceber ideias e o ato de colocá-las em prática em processos que envolvem atividades de comunicação.

A explanação dessas definições e desses posicionamentos contribuiu para o processo de construção do conceito proposto. Mas, para dar continuidade ao processo, foi interessante compreender e procurar caracterizar o que podem ser considerados Ambientes Multimodais. A compreensão desse conceito é fundamental por algumas razões.

Em primeiro lugar, pelo fato de que, embora não se pretenda restringir o conceito ao ambiente, é meritório caracterizar e delimitar a originalidade do contexto criado no projeto "Barômetro". A experiência já demonstrou que ele é flexível e 
adaptável a diversos espaços físicos. Em segundo lugar, é também meritório diferenciá-lo dos demais ambientes hoje reconhecidos e considerados como multimodais, em especial os relacionados aos contextos virtuais. Por sinal, o virtual é um de seus elementos que lhe confere uma de suas características mais marcantes, todavia encontra, nos demais elementos, a complementaridade do dispositivo.

\subsection{Ambientes multimodais}

Quando se fala em multimodalidade ou em ambientes multimodais, as condições ligadas à virtualidade e aos ambientes virtuais são os primeiros a aparecerem no processo de buscas. Embora se tenham falado muito em salas de aulas multimodais ou outros espaços, o virtual e as interações por eles permitidas constituem um parâmetro muito forte. Dessa maneira, a definição ou definições sobre o que são ou seriam esses ambientes tiveram como ponto de partida os ambientes virtuais.

Martin, Daly e Thurston (2005) entenderam esses ambientes como aqueles em que o usuário experimenta e interage através da utilização de mais de um sentido ou da interação técnica. Em outras palavras, um ambiente que promova um feedback ao mesmo tempo visual e auditivo. Os autores, em seguida, trouxeram uma afirmação considerável: para eles, os ambientes mais interessantes são aqueles que empregam os feedback táteis e/ou olfativos em adição ao visual e auditivo. Há também a possibilidade de inserção do gustativo ou do gosto, que segundo eles não vem ao caso na discussão proposta.

Do ponto de vista interativo, sistemas que utilizam mais de uma técnica também podem ser considerados como multimodais. Os autores citaram como exemplos um sistema que proporciona um joystick para locomoção, bem como um sistema de reconhecimento de fala para aceitar comandos que modificam 0 ambiente, ambos podem ser chamado de ambientes multimodais.

Outro aspecto citado por eles diz respeito ao uso dos sentidos e como os usuários vão experimentar, vivenciar esses ambientes. Como que a inserção de elementos que estimulam os sentidos pode contribuir para a presença e a imersão do usuário no ambiente criado. Para finalizar, é consenso entre eles, quanto maior o número de possibilidades de estímulo aos sentidos, melhor é o processamento das informações circuladas entre os usuários. 


\subsection{Dispositivo pedagógico multimodal}

O conceito de Dispositivo Pedagógico Multimodal (DPM) teve como base não apenas a pesquisa que trouxe esclarecimentos sobre os termos, significados e usos, mas a experiência proporcionada pelos acontecimentos na proposta inovadora dos eventos dos Cafés Científicos oferecida pelo "Barômetro - Ciência, café e debate".

A concepção de Bernstein (1990) sobre Dispositivo Pedagógico (DP) foi descrita e analisada no texto no momento em que o projeto "Barômetro" foi apresentado. $\mathrm{O}$ autor partiu do pressuposto de que a forma de comunicação nas escolas e universidades é extremamente especializada e que, por isso, assume diferentes perspectivas. Seu foco residiu em como funciona a lógica interna do que ele chamou de Dispositivo Pedagógico, fundamental para a produção, reprodução e transformação da cultura.

A estrutura interna do DP, seja ele formal ou informal, é dividida em três conjuntos de regras, em uma estrutura hierárquica, são elas - distributivas, de recontextualização e avaliativas. As regras distributivas determinam quem pode transmitir o que a quem e sob quais condições; as de recontextualização deslocam o discurso de seu local de prática e the confere nova ordem, novo enfoque; e as avaliativas constituem o local da prática pedagógica.

A "Análise I", referente ao estudo do contexto do Barômetro e as concepções de Lewestein (2003) e Bernstein (1990) e os diferentes contextos de Cafés Científicos (CC) pesquisados, demonstrou que os dois primeiros contextos não somente se encaixaram nas concepções de Bernstein (1990) como reproduziram, de certa forma, práticas cotidianas do espaço escolar. Uma das motivações dos criadores dos CC era a de justamente romper ou buscar novas perspectivas para essas práticas. O terceiro contexto, embora bem diferenciado em sua estrutura, também se encaixou. Esse fato levantou evidências de que é um tanto quanto complexo romper com determinadas práticas instauradas seja na esfera social, seja nas demais esferas de produção do conhecimento. A inovação seria o caminho mais indicado.

Nesse sentido, surgiu a perspectiva de se agregar ao DP de Bernstein (1990) e suas regras e a compreensão de sua estrutura interna novos elementos, em uma tentativa não de apenas trazer a inovação, mas de reestruturar seu funcionamento, sua lógica. A multimodalidade veio como esse viés inovador, criador de outra lógica, 
promovedor de outros tipos de participação e interação, de outras formas de recontextualização.

A dimensão multimodal colocou o estímulo aos sentidos como um dos ou o principal elemento do dispositivo. A participação dos atores se deslocou um pouco das formas convencionais ao explorar a visão, a audição, o tato, o gesto, o paladar, o corpo, de forma simultânea. Os estímulos não se restringiram somente ao contexto do DP, mas começaram antes do contexto se estabelecer e se ampliaram no decorrer de seu acontecimento.

Os aspetos presencial e virtual complementaram o conjunto de elementos que compuseram a caracterização do ambiente sob o viés da multimodalidade. O presencial possibilitou que os demais atores vivenciassem e experimentassem a multiplicidade de elementos. O virtual possibilitou a ampliação do espaço de forma a transcender o dispositivo por meio de mídias diversas como o rádio e a web. Algumas das experiências vividas pelo presencial, não todas, também foram possíveis de acontecer no virtual, dentro de seus limites. Uma nova estrutura foi criada, novos elementos foram agregados e novas regras então se estabeleceram: as da multimodalidade.

As regras da multimodalidade ampliaram as possibilidades de participação e interação através do estímulo aos sentidos, de recursos de ordem estrutural e tecnológica e da utilização de diferentes mídias, seja ao que se referiu ao presencial, seja ao que se referiu ao virtual. A seguir as figuras 4,5 e 6 ilustram, respectivamente, os estímulos aos quais eram submetidos o público participante visual, textual, áudio, tátil, gestual, paladar (4); os estímulos aos quais eram submetidos o público ouvinte pela internet - áudio, visual, tátil (5); os estímulos aos quais eram submetidos o ouvinte pelo rádio — áudio (6). 
Figura 4 - Esquema do Público Participante presencial e o os estímulos do DPM

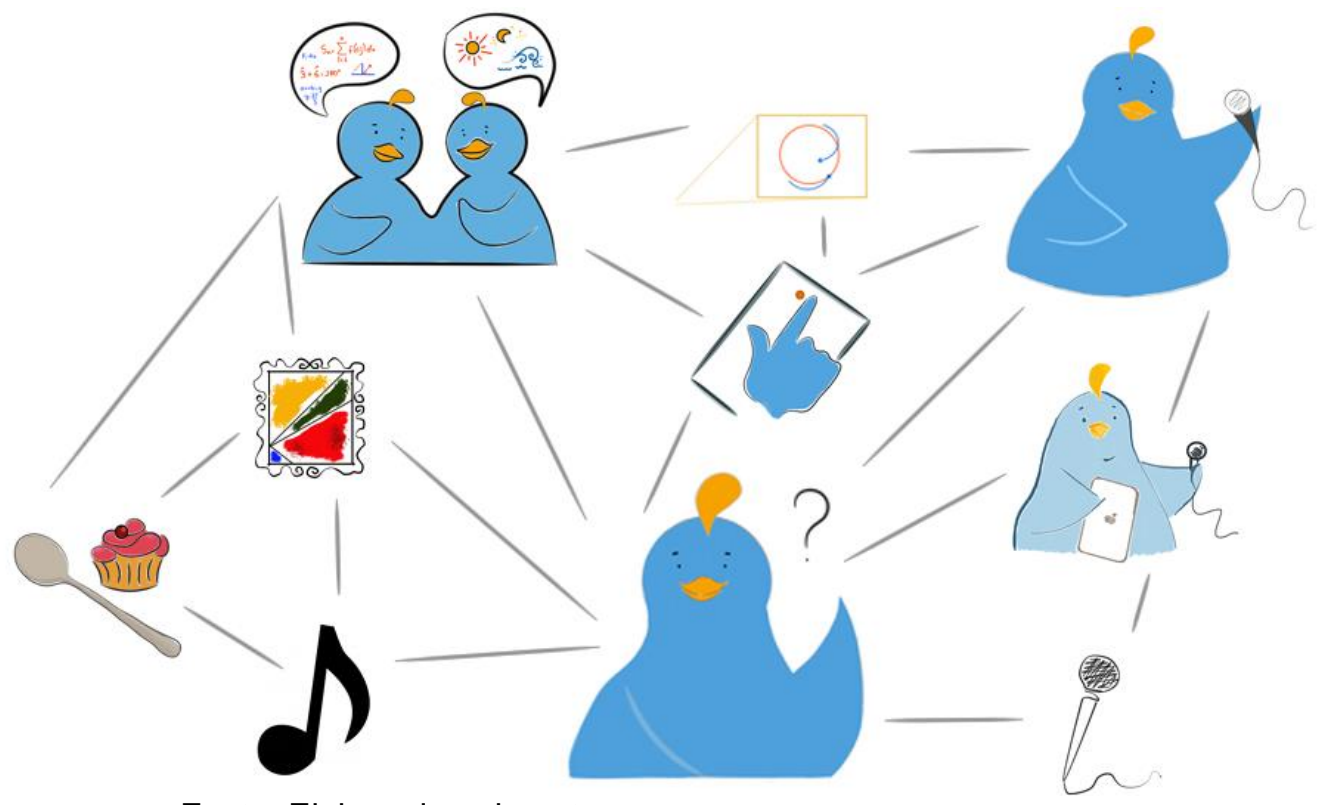

Fonte: Elaborado pela autora.

Nota: Ilustração de Ana Carolina Rodarte.

Figura 5 - Esquema do Ouvinte Internet

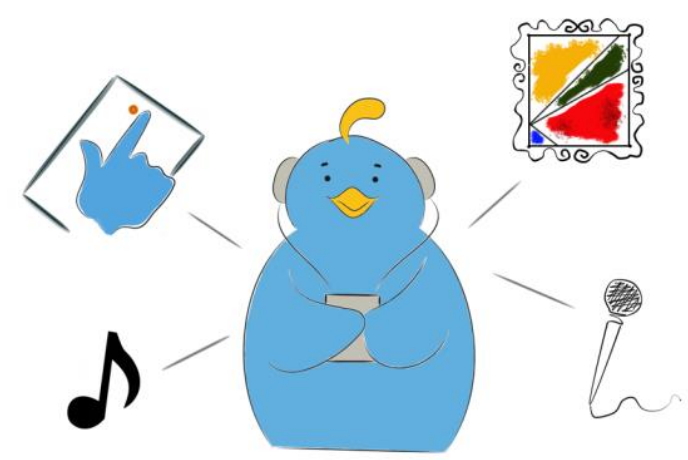

Fonte: Elaborado pela autora.

Nota: Ilustração de Ana Carolina Rodarte.

Figura 6 - Esquema do Ouvinte Rádio

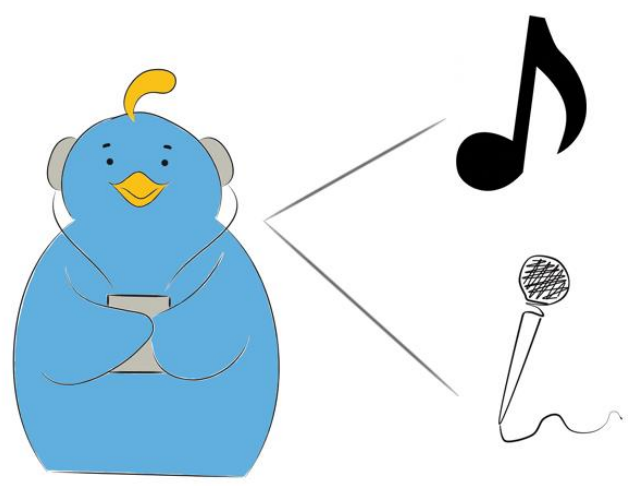

Fonte: Elaborado pela autora.

Nota: llustração de Ana Carolina Rodarte. 


\section{Dispositivos Pedagógicos multimodais - o conceito em um parágrafo}

Dispositivos Pedagógicos Multimodais (FIGURA 7) incorporam às regras de distribuição, de recontextualização e de avaliação dos Dispositivos Pedagógicos de Bernstein (1990) uma quarta regra, ou seja, as regras da multimodalidade.

Figura 7 - Esquema do Ambiente Multimodal

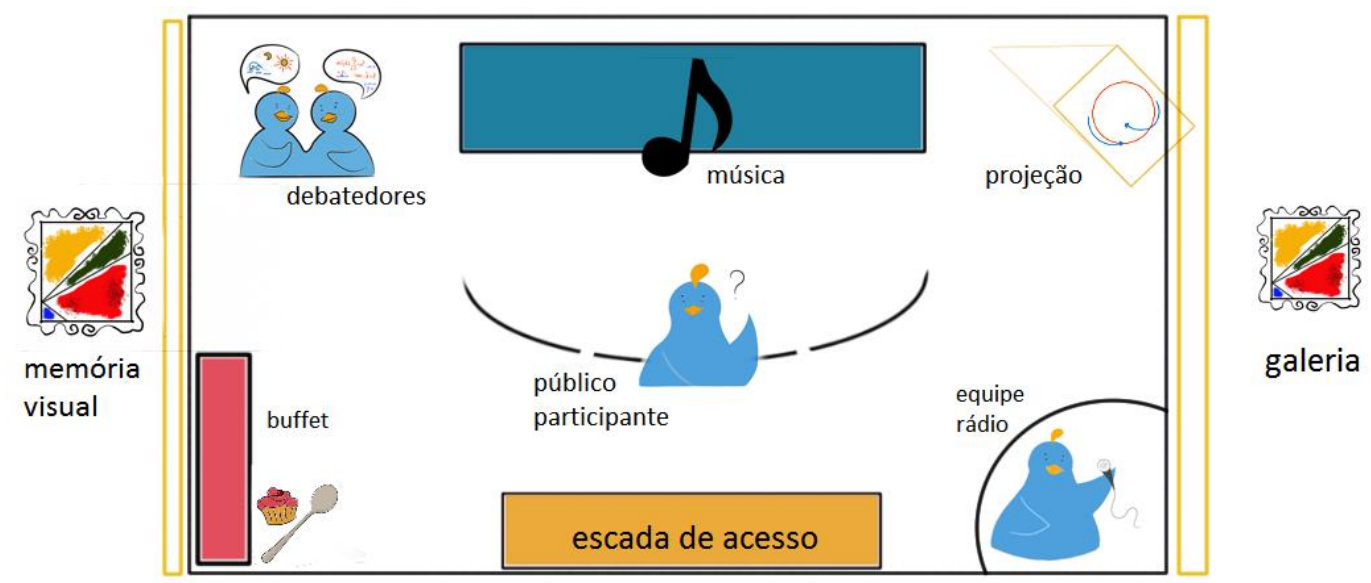

Fonte: Elaborado pela autora.

Nota: llustração de Ana Carolina Rodarte.

As regras distributivas determinam quem pode transmitir o que a quem e sob quais condições, as de recontextualização deslocam o discurso de seu local de prática e the confere nova ordem, novo enfoque e, as avaliativas constituem o local da prática pedagógica. As regras da multimodalidade vão promover o estímulo aos sentidos, incentivar a participação e a interação com maior intensidade, fazer uso de tecnologias, utilizar diferentes recursos da mídia, permitir a simultaneidade entre o presencial e o virtual, possibilitar que os espaços sejam transcendidos. Essas regras, em conjunto com as demais, vão agregar novos elementos aos padrões estabelecidos para a produção e circulação do discurso pedagógico de forma a possibilitar o surgimento de formas diferenciadas de produção, reprodução e transformação da cultura. As fotografias 4, 5, 6, 7 e 8 ilustram os estímulos e as situações criados pelo ambiente multimodal e esquematizados no desenvolvimento do conceito proposto. 
Foto 4 - Projeção da Esfera Semântica e das perguntas enviadas pelo tablet, Barômetro Ciência e Inclusão social

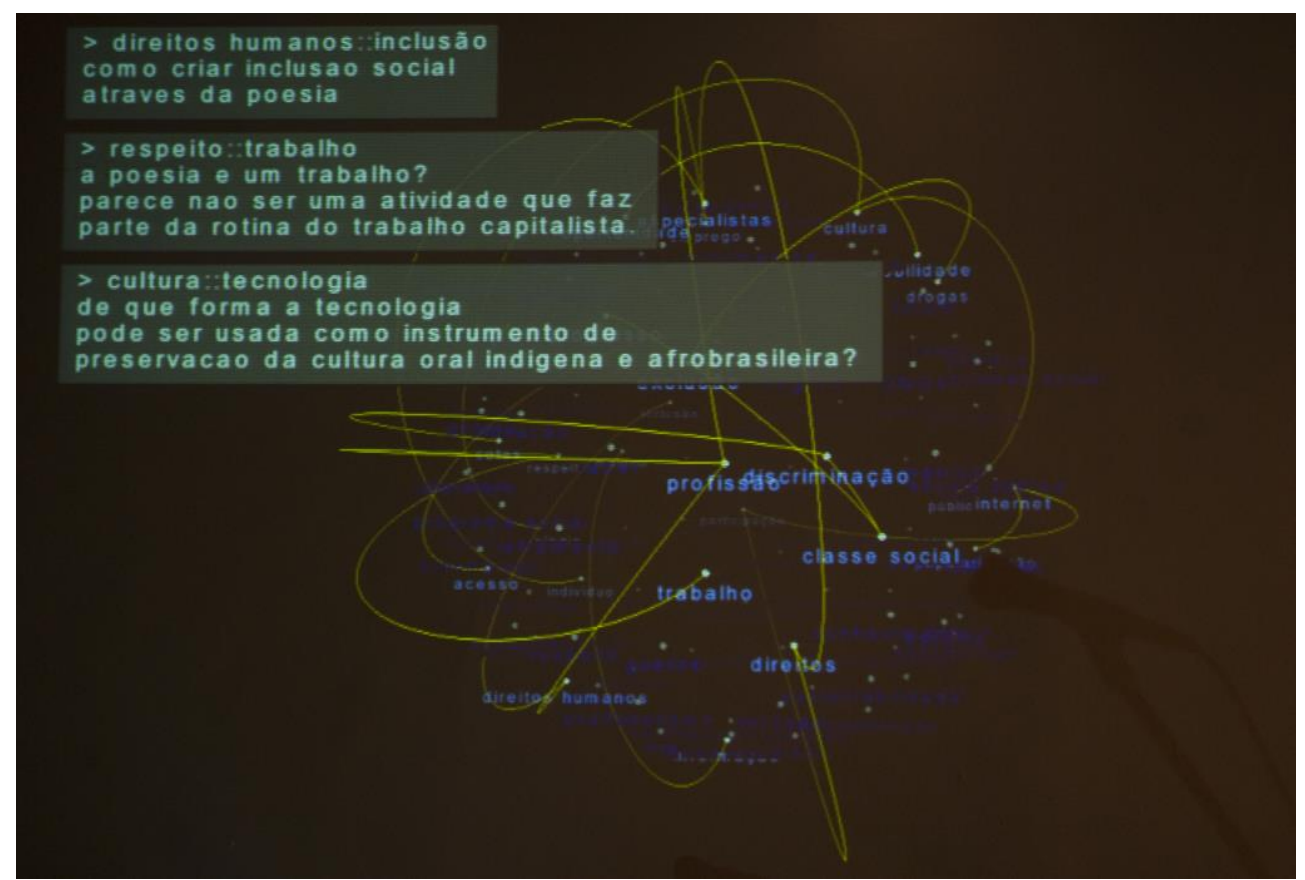

Fonte: VENTURA, 24 nov. 2011.

Foto 5 - Instrumentos à espera dos músicos, minutos antes do programa ir ao ar, Barômetro Ciência e Sala de aula

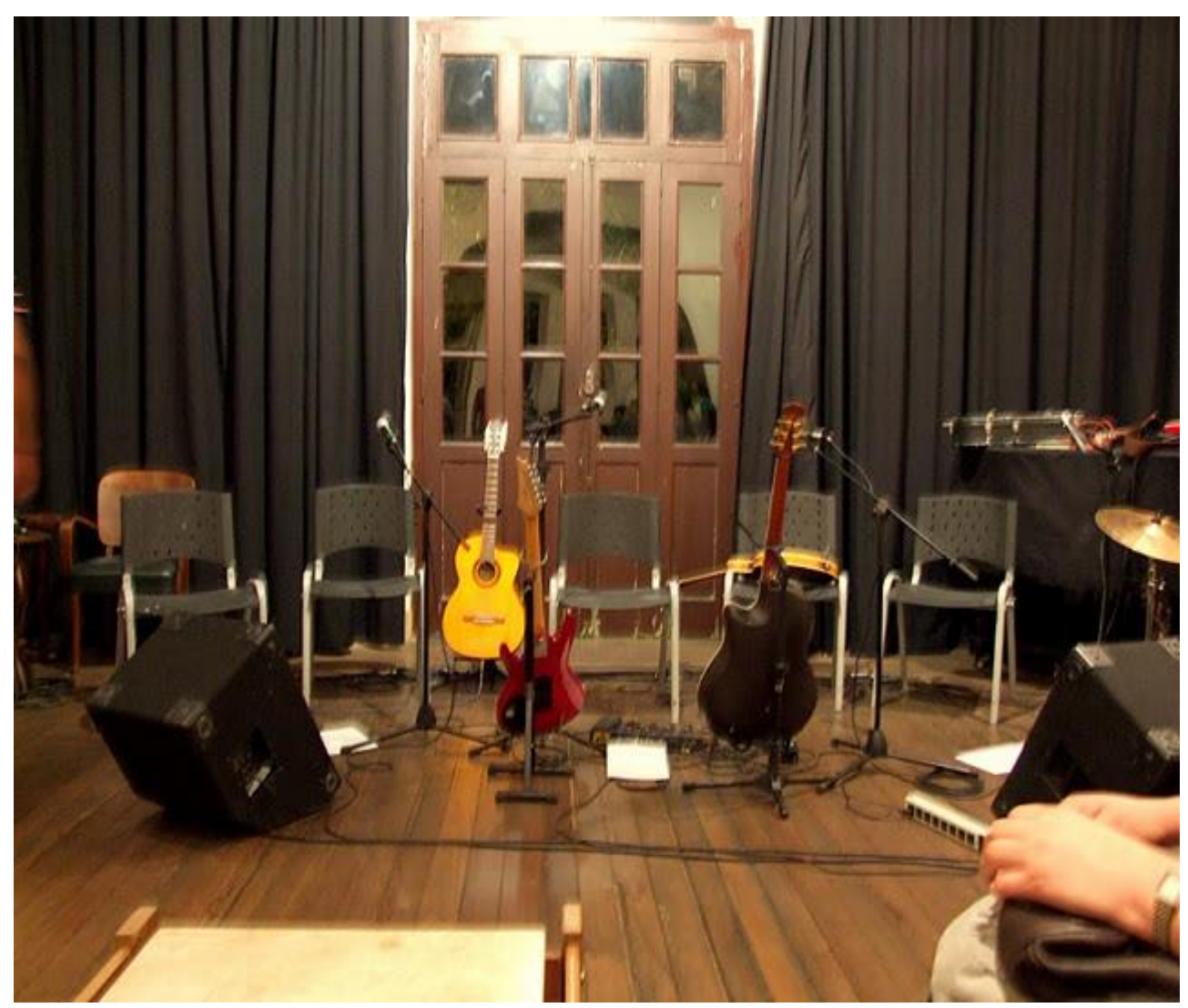

Fonte: VENTURA, 29 set. 2011. 
Foto 6 - Barômetro Ciência e Sala de aula

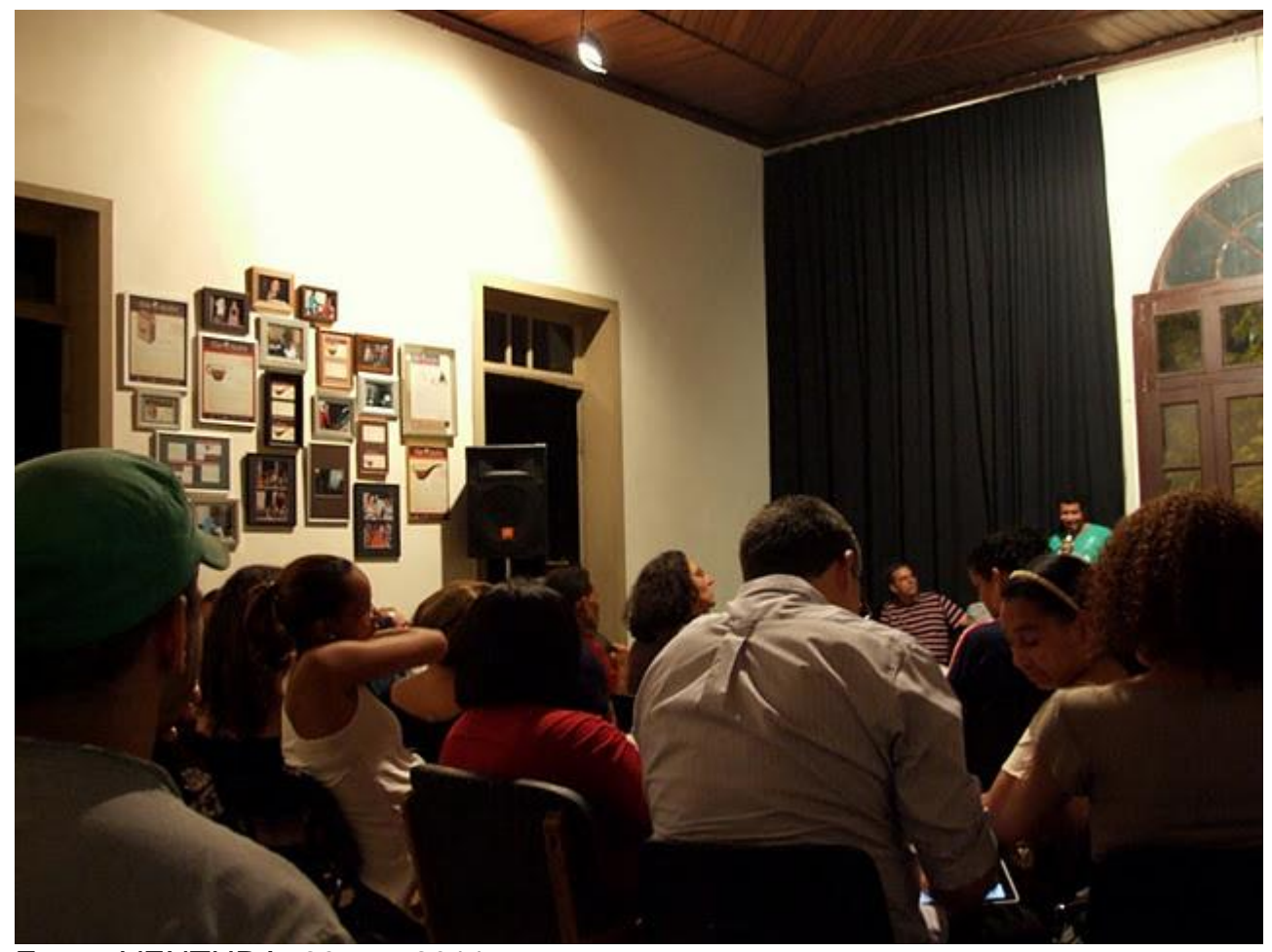

Fonte: VENTURA, 29 set. 2011.

Foto 7 - Público participante elabora perguntas no teclado virtual, Barômetro Ciência e Inclusão Social

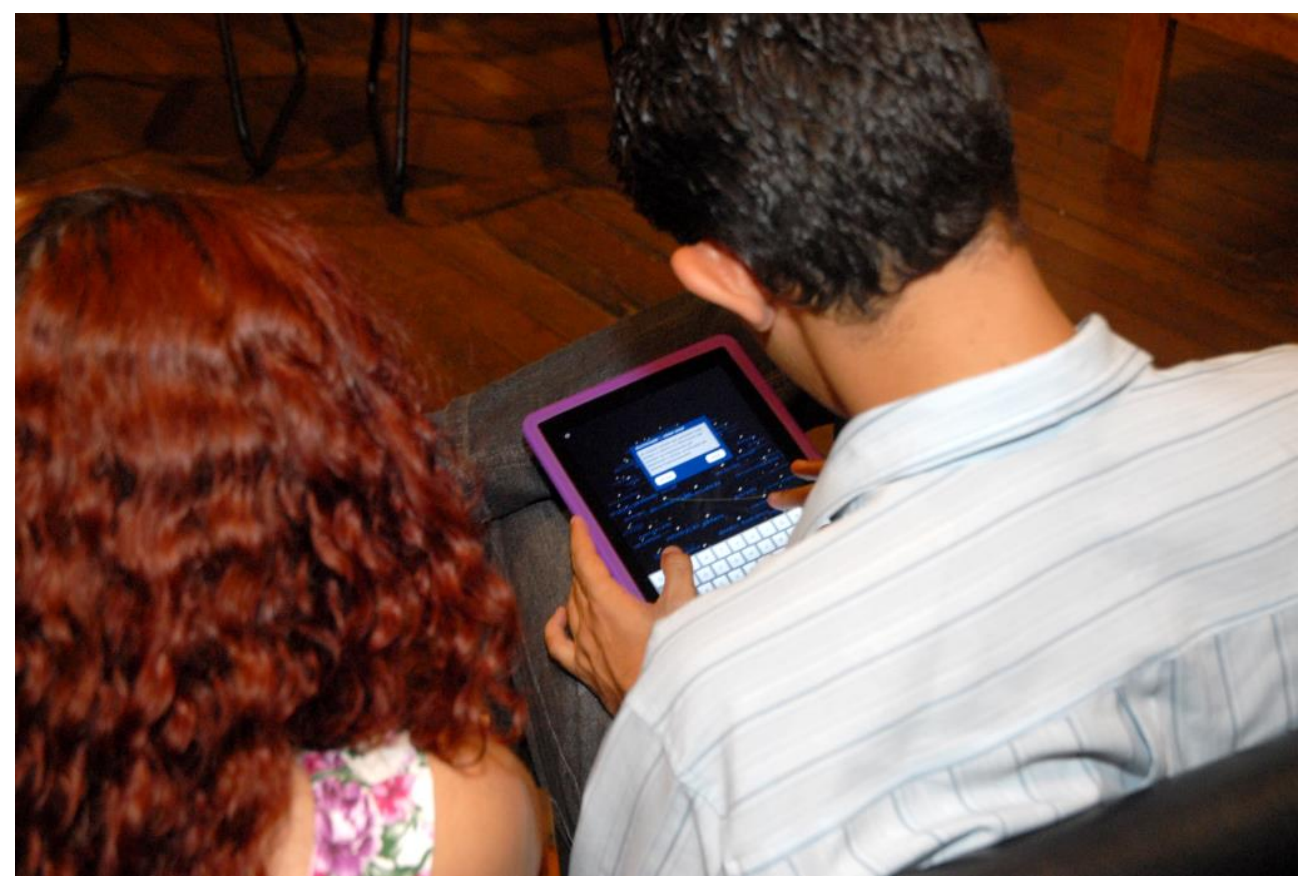

Fonte: VENTURA, 24 nov. 2011. 
Foto 8 - Público participante manuseia o tablet, Barômetro Ciência e Dengue

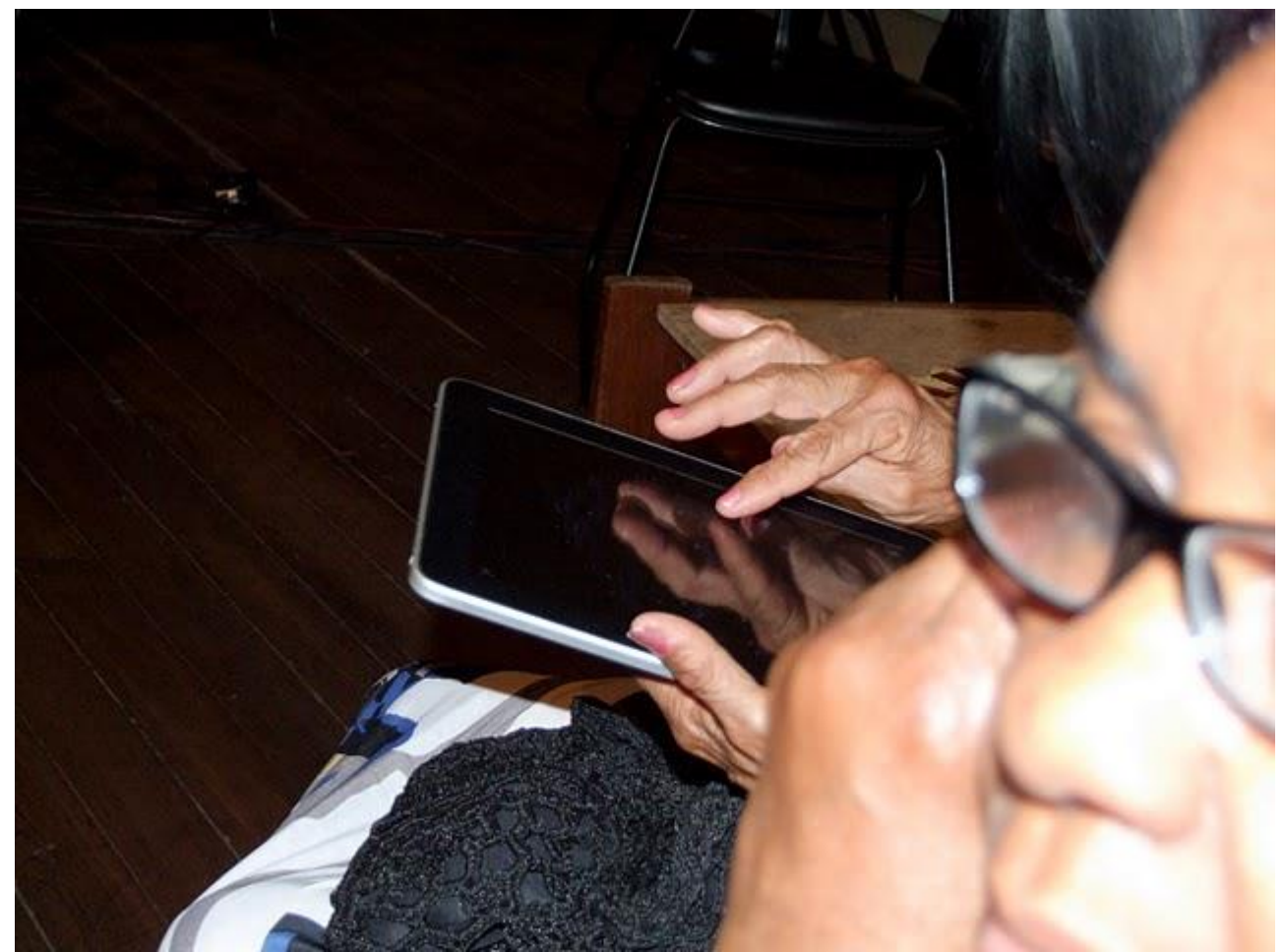

Fonte: VENTURA, 14 abr. 2011.

Foto 9 - Peça de roupa confeccionada com material reciclado que foi apresentada ao público por um dos debatedores convidados, Barômetro Ciência e Design

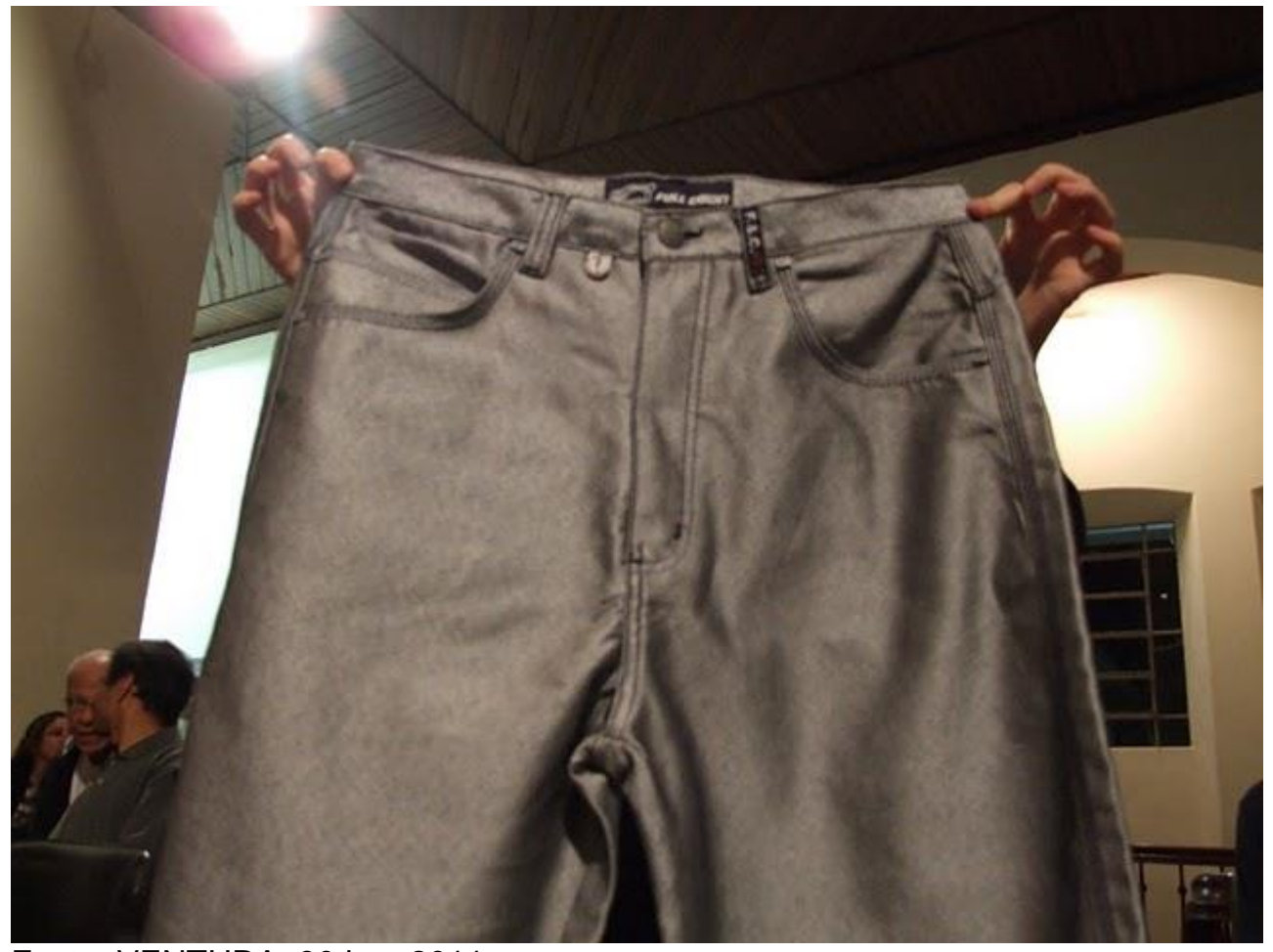

Fonte: VENTURA, 30 jun. 2011. 
6 ESTRUTURA CONCEITUAL

Quadro 8 - Estrutura Conceitual: Bernstein, Lewestein e os três contextos

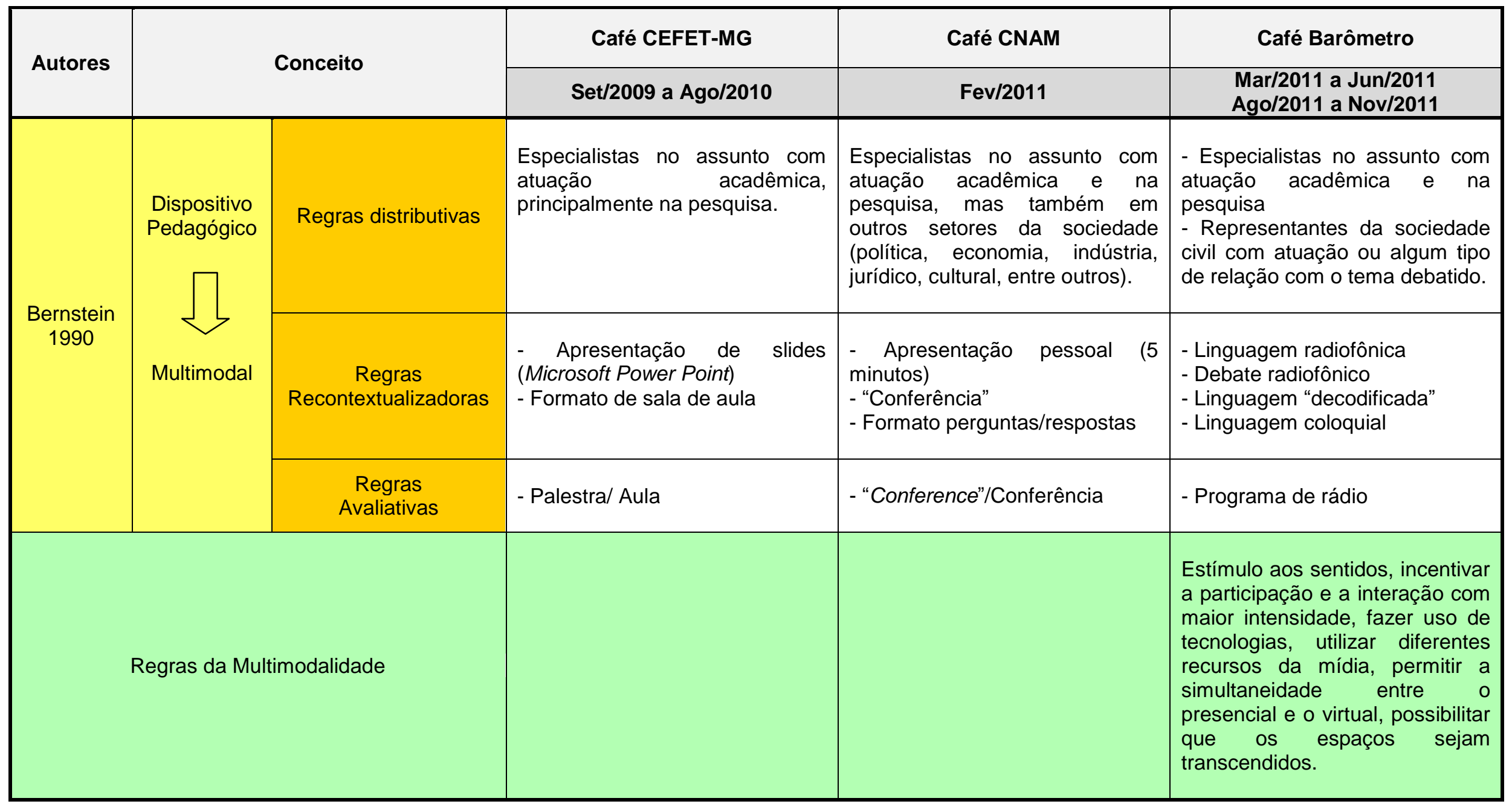


(continuação)

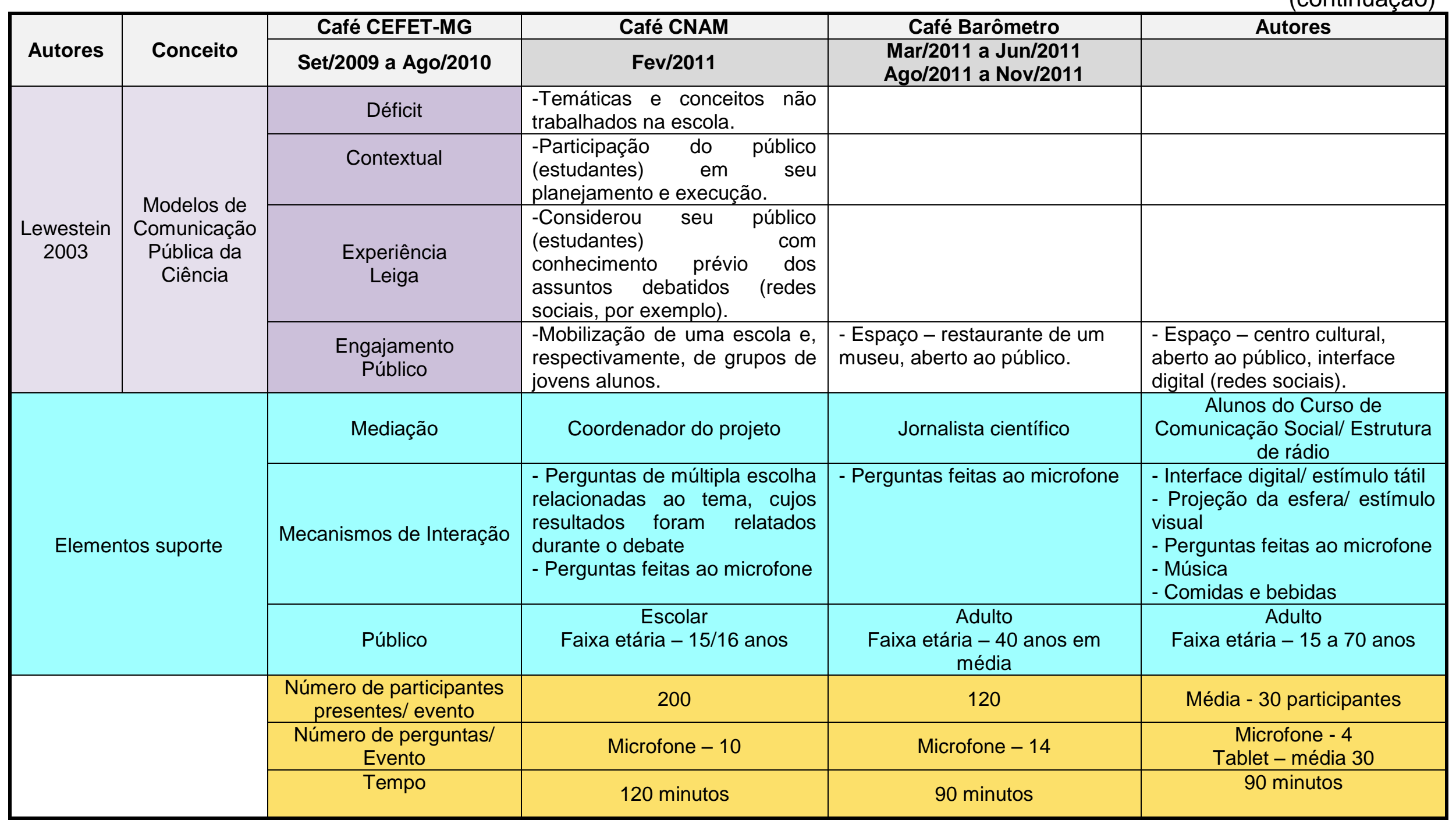

Fonte: Elaborado pela autora. 


\section{INDICAÇÕES METODOLÓGICAS}

Esta tese aplicou um conjunto de procedimentos metodológicos na tentativa de adequá-los aos diferentes contextos de coleta de dados. Entre eles, a abordagem qualitativa da situação social através da qual aconteceram as interações foi o procedimento metodológico principal, seguido pela pesquisa documental e por uma série de procedimentos de análise que tiveram a multimodalidade e os componentes da tríade como elementos balizadores.

Para Gibbs (2009), tornou-se cada vez mais difícil entrar em um consenso para definir o que é pesquisa qualitativa. Abordagens diferenciadas à parte, ele afirmou que é possível identificar certas características comuns entre os pesquisadores de campo.

Assim, segundo ele, esse tipo de pesquisa tem como objetivo abordar 0 mundo exterior, que ele atribuiu como não sendo os tradicionais contextos de pesquisa, como os laboratórios, para entender, descrever e explicar os fenômenos sociais do mundo interior. De acordo com o autor, isso pode ser feito de diversas maneiras. Analisar experiências de indivíduos ou grupos, examinar interações e comunicações que estejam se desenrolando, investigar documentos, sejam eles textos, imagens, filmes, dentre outros.

O que essas abordagens possuem em comum está no fato de que almejam buscar e esmiuçar o modo como as pessoas constroem o mundo que está em seu entorno, o que fazem ou o que acontece do que disso lhes faz sentido.

Gibbs (2009) tocou em um ponto especial em relação à forma como o material empírico foi especialmente abordado nesta pesquisa. Para ele, as interações e os documentos são formas de constituir, às vezes de maneira conflituosa, processos e artefatos sociais. As abordagens que esse tipo de pesquisa permite representam formas de sentido.

\section{1 $O$ universo da coleta de informações}

A coleta de informações foi realizada através de gravações, marcações de tempo e registros textuais. Os dados do público participante foram coletados através do caderno de assinaturas. Esses dados possibilitaram a construção do perfil do público participante dos eventos. Na sequência, estão as fontes documentais para subsidiar a análise: 
1- Áudio através dos CDs da transmissão fornecidos pela equipe da Rádio 104,5 UFMG Educativa:

- Análise das interações surgidas nos eventos - transcrições e quadro de narrativas;

- Análise dos tempos de fala/ capital de fala através da contagem de tempo fornecida pela equipe da Rádio 104,5 UFMG Educativa.

2- Informações registradas no caderno de assinaturas onde foram solicitados alguns dados pessoais do público participante e registros espontâneos deixados no caderno de opiniões, respectivamente:

- Nome, idade, profissão, email;

- Críticas, opiniões, comentários, sugestões.

3- Esfera Semântica:

- Banco de dados gerado pelo software;

- Perguntas enviadas pelo tablet que vieram a público.

A pesquisa documental foi o primeiro procedimento metodológico a ser adotado e possibilitou o conhecimento e entendimento dos Cafés Científicos desde sua origem até seus acontecimentos em termos mundiais.

As anotações do caderno de campo acompanharam todo o desenrolar da pesquisa e foram fundamentais para a localização de dados e informações registrados em momentos inesperados.

\subsection{A transmissão da rádio}

A transmissão em tempo real realizada pela rádio institucional proporcionou outra fonte de dados de extrema importância. As interações ocorridas na forma oral foram transcritas no quadro de narrativas. As perguntas ou comentários enviados pelo tablet foram registrados no banco de dados gerado pelo software. Esses registros constituíram os momentos mais ricos da fase de relação e análise de dados.

Em segundo lugar, a gravação da emissão dos programas possibilitou contabilizar os tempos de fala de cada situação ocorrida nas interações. Dessa 
maneira, foi possível quantificar e saber, das principais fontes de fala - debatedor da ciência, debatedor da sociedade civil, público presente - quem falou mais, em que momento essa fala foi mais longa e por que. Desse processo de contagem do tempo, constaram também as interlocuções das repórteres da rádio que fizeram as apresentações e a mediação entre debatedores, público presente e público ouvinte.

A equipe do projeto juntamente com a equipe da rádio preparou um roteiro (script) para a transmissão. Isso não significou que o roteiro sempre foi seguido à risca em relação ao tempo, mas permitiu flexibilidade em relação às interações ocorridas.

\subsection{A interface da internet e o Twitter — o público ouvinte}

O público ouvinte da rádio pôde ter acesso à transmissão do evento tanto através da internet, quanto pelo aparelho de rádio. Aqueles que acessaram a rádio pela internet tinham à disposição um dos recursos das redes sociais mais interativos, ou seja, o twitter. Através do twitter os ouvintes, que para a pesquisa se integraram ao conjunto do público ouvinte, enviaram perguntas e comentários que podiam, dada a relevância da intervenção para a equipe da rádio, ser transmitidos aos debatedores durante a transmissão.

\subsection{0 caderno de assinaturas e o caderno de opiniões}

Em cada evento, dois cadernos ficaram disponíveis para que o público presente pudesse registrar dois tipos de dados. No primeiro, o caderno de assinaturas, foi solicitado ao público participante: nome, profissão, idade e e-mail ou telefone. Através desses registros foi possível saber um pouco sobre o público participante, manter contato através de um processo de comunicação constante a cada "Café" e, principalmente, quais pessoas desse público participaram dos demais eventos do café.

O outro caderno permitiu um tipo de registro mais espontâneo ao solicitar que o público participante se manifestasse de maneira livre para deixar depoimentos, críticas e sugestões sobre os eventos. Quem escrevesse nesse caderno não teria a necessidade de assinar. 


\subsection{A esfera semântica}

O software desenvolvido para a Esfera Semântica (ES) gerou, a cada evento, um banco de dados composto pelas tabelas com os registros das combinações de palavras, perguntas e comentários. Através desse banco de dados, foi possível estabelecer as correlações a seguir:

- Ocorrências e número de palavras do campo semântico da ciência utilizadas pelo público presente;

- Ocorrências e número de palavras do campo semântico do tema debatido utilizadas pelo público presente;

- Número de pares de palavras transformadas em perguntas ou comentários pelo público presente através dos tablets;

- Número de pares de palavras recorrentes;

- Número de pares de palavras referentes somente à ciência, somente ao tema debatido e, à relação ciência x tema debatido;

- Categorização das perguntas ou comentários enviados pelo público presente através dos tablets;

\subsection{A escolha das perguntas ou comentários - a "repórter tablet" e sua assistente}

Não houve interferência na escolha das perguntas que foram passadas aos debatedores pela equipe da rádio. Na medida em que a esfera foi alimentada pelas perguntas ou comentários, uma repórter e sua assistente faziam a relação das perguntas e escolhiam, naquele bloco de debates, quais seriam transmitidas em tempo real.

\subsection{Diário de bordo - o caderno de campo}

As observações locais, coletadas a cada programa, foram registradas em um diário de bordo. Essas anotações registraram os fatos que não estavam previstos dentro dos quesitos programados e cuidadosamente organizados. O caráter inusitado das informações nele contidas em relação aos debatedores, à equipe de repórteres da rádio, ao público participante, ao debate e à imprensa, trouxe indicações preciosas e essenciais para o andamento dos demais procedimentos 
metodológicos e dos procedimentos de análise. O texto completo se apresenta no Apêndice $C$.

O Quadro 9 apresentou a relação entre os objetivos específicos e os procedimentos metodológicos aplicados para atingi-los.

Quadro 9 - Relação entre objetivos específicos e procedimentos metodológicos

\begin{tabular}{|l|l|}
\hline \multicolumn{1}{|c|}{ Objetivos Específicos } & \multicolumn{1}{c|}{ Procedimentos Metodológicos } \\
\hline $\begin{array}{l}\text { 1- Desenvolver dispositivo pedagógico } \\
\text { com base em interações multimodais }\end{array}$ & $\begin{array}{l}\text { 1- Pesquisa documental/ Participação em } \\
\text { eventos de Cafés Científicos }\end{array}$ \\
\hline $\begin{array}{l}\text { 2- Analisar e entender o funcionamento } \\
\text { desse dispositivo }\end{array}$ & $\begin{array}{l}\text { 2- Análise temática: áudio/ Esfera } \\
\text { Semântica (ES)/ quadro de narrativas/ } \\
\text { Observações locais }\end{array}$ \\
\hline $\begin{array}{l}\text { 3- Entender como esse dispositivo } \\
\text { estimula a comunicação pública da } \\
\text { ciência }\end{array}$ & $\begin{array}{l}\text { 3- Pesquisa documental/ Análise } \\
\text { temática: áudio/ Esfera Semântica/ } \\
\text { Observações locais }\end{array}$ \\
\hline $\begin{array}{l}\text { 4- Identificar as posições enunciativas } \\
\text { dos representantes da comunidade } \\
\text { científica }\end{array}$ & $\begin{array}{l}\text { 4- Consulta Currículo Lattes/ Análise } \\
\text { temática }\end{array}$ \\
\hline $\begin{array}{l}\text { 5- Identificar as posições enunciativas } \\
\text { dos representantes da sociedade civil }\end{array}$ & $\begin{array}{l}\text { 5- Informações colhidas pessoalmente / } \\
\text { Análise temática }\end{array}$ \\
\hline $\begin{array}{l}\text { 6- Identificar as interações discursivas } \\
\text { que se estabeleceram entre eles }\end{array}$ & $\begin{array}{l}\text { 6- Análise temática: áudio/ quadro de } \\
\text { narrativas/ banco de dados da ES }\end{array}$ \\
\hline $\begin{array}{l}\text { 7- Identificar o público dos Cafés } \\
\text { Científicos/ quais suas posições } \\
\text { enunciativas }\end{array}$ & $\begin{array}{l}\text { 7- Caderno de assinaturas/ Caderno de } \\
\text { opiniões/ Análise temática }\end{array}$ \\
\hline $\begin{array}{l}\text { 8- Identificar suas formas de } \\
\text { participação/ interação nesse dispositivo }\end{array}$ & 8- Observações locais \\
\hline $\begin{array}{l}\text { 9- Identificar as posições enunciativas do } \\
\text { público em relação à ciência/ } \\
\text { representantes comunidade científica/ } \\
\text { representantes sociedade civil }\end{array}$ & $\begin{array}{l}\text { 9- Análise temática: áudio/ banco de } \\
\text { dados da ES/ quadro de narrativas }\end{array}$ \\
\hline
\end{tabular}

Fonte: Elaborado pela autora. 


\section{ANÁLISE}

O universo de dados gerados no decorrer da pesquisa e, principalmente, no decorrer dos eventos acabou por exigir, no processo de elaboração da análise, a organização das diferentes etapas pelas quais a coleta de dados perpassou. Essa abordagem foi necessária para o momento de cruzamento dos quesitos de pesquisa (hipótese, objetivos, metodologia) com o material coletado.

O ponto de partida foi pela análise dos contextos dos eventos e dois de seus referenciais teóricos principais - os modelos de comunicação pública da ciência de Lewestein (2003) e os dispositivos pedagógicos de Bernstein (1990).

O próximo passo foi pela abordagem dos mecanismos utilizados para estimularem as interações, aqui denominados de "elementos geradores da interação", são eles:

- nos eventos:

- a esfera semântica;

- as combinações de palavras e as perguntas ou comentários enviados pelos tablets;

- as perguntas selecionadas pela equipe da rádio (APÊNDICE B) que se tornaram públicas nos eventos;

- as perguntas feitas através do microfone pelo público participante;

- as respostas e os posicionamentos dos debatedores;

- pós-eventos, os elementos suporte:

- os tempos de fala considerando os ajustes do programa e as contribuições desses tempos para o processo de análise;

- as tabelas geradas pelo software contendo todas as combinações de palavras e perguntas (inclusive as que não se tornaram públicas) que foram posteriormente relacionadas e categorizadas;

- as transcrições dos programas que geraram o quadro de narrativas do Barômetro.

O desenho proposto pressupôs o fluxo da análise de uma escala macro para uma escala micro e seguiu o mesmo caminho feito pelo público durante os debates e o caminho delineado para a pesquisa. 
Para maior refinamento do processo, os procedimentos da análise temática foram aplicados a somente um dos programas de forma a buscar maior profundidade e detalhamento das interações do quadro de narrativas que pudessem evidenciar as colocações da hipótese apresentada.

\subsection{Análise I}

\subsubsection{Lewestein e Bernstein e o "Barômetro - ciência, café e debate"}

O percurso desta pesquisa teve início nos eventos de Café Científico na modalidade Júnior do projeto proposto pela equipe do CEFET-MG, passou pelo Café des Techniques do CNAM de Paris e chegou até a concepção de seu próprio modelo através do projeto "Barômetro - ciência, café e debate". A trajetória percorrida teve abertura para que ao longo do caminho elementos de natureza teórica e natureza prática que pudessem agregar valor fossem sempre bem-vindos. $\mathrm{Na}$ medida em que o projeto tomava corpo, tanto na parte textual quanto na concepção de seu modelo propriamente dito, ensaios de análise foram acontecendo paralelo a tudo isso. Um desses ensaios consistiu da análise dos acontecimentos do primeiro contexto de coleta de dados, o Café Júnior, sob a ótica dos modelos de comunicação pública da ciência de Lewestein (2003) e dos dispositivos pedagógicos de Bernstein (1990), integrados ao corpus da pesquisa durante a concepção do terceiro contexto. As conclusões desse ensaio inicial, a seguir, foram de grande importância porque permitiram conhecer e ao mesmo experimentar referenciais teóricos pertinentes para a fundamentação da hipótese.

A análise foi baseada nas interações entre os debatedores e os alunos do ensino médio convidados para os debates. A primeira constatação valeu para todas as demais modalidades que possam assumir os Cafés Científicos, ou seja, não importa sob qual modalidade, são espaços de comunicação pública da ciência. Lewenstein (2003), ao propor seus modelos de comunicação pública, enfatizou que eles somente fornecem uma ferramenta esquemática que auxilia na compreensão das atividades dessa comunicação. Segundo ele, na prática essas atividades combinam seus elementos entre si. Mas, o que concluiu de forma mais significativa foi a necessidade de refinamento desses modelos para entender as relações entre 0 que foi idealizado e o que realmente aconteceu. Suas preocupações apareceram em todo o processo de planejamento e execução dos "Cafés Júnior" do primeiro 
contexto e continuaram a valer, principalmente, para o modelo concebido no terceiro contexto. O refinamento aconteceu a cada evento, a cada programa, tanto pela equipe do "Barômetro" quanto pela equipe da rádio.

Ao inserir o primeiro contexto, o Café Junior, em seus modelos, pode-se dizer que ele assumiu a modalidade déficit porque trouxe esclarecimentos sobre assuntos complexos e polêmicos como aquecimento global, em cima do qual existem controvérsias até mesmo da parte dos cientistas. As posições contrárias dos debatedores demonstraram isso. É um modelo de contextualização uma vez que contou com a participação da própria audiência desde o momento de seu planejamento. É um modelo de experiência leiga porque considerou sua audiência usuária e integrada nos assuntos debatidos, como as redes sociais. Por fim, é um modelo de participação pública porque aconteceu através da mobilização de uma escola, de grupos de jovens alunos, de futuros cidadãos formadores de opinião.

Quanto ao conceito de dispositivo pedagógico de Bernstein (1990), os eventos desse "Café" se adequaram aos seus pressupostos. Para esse autor, o discurso pedagógico ou a forma de comunicação especializada que acontece nas escolas e universidades, é transmissor das relações de poder que acontecem fora da escola. A dinâmica dos "Cafés" tenta, justamente, desconstruir ou construir de maneira diferenciada esse discurso, essas relações de poder. Mas para realizar essa desconstrução nos "Cafés" é necessário estabelecer uma estrutura interna para seu funcionamento e finalidade. Para isso, Bernstein (1990) propôs as três regras, distributivas, de recontextualização e avaliativas, e caracterizou o discurso pedagógico em discurso de inserção, instrucional e regulamentar.

As regras distributivas determinam quem pode transmitir o que a quem e sob quais condições, as de recontextualização deslocam o discurso de seu local de prática e lhe confere nova ordem, novo enfoque e, as avaliativas constituem o local da prática pedagógica. $O$ discurso de inserção indica que há sempre um discurso inserido em outro, isto é, um discurso instrucional dominado por um discurso regulamentar.

As interações que emergiram nos Cafés Junior transitaram pelas concepções de Bernstein (1990). Sempre há um representante da comunidade científica que traz consigo a autoridade do conhecimento científico e o respaldo da pesquisa científica para uma audiência, no caso do "Café Júnior", selecionada e preparada para recebê-lo. Mas a recontextualização aconteceu? Os representantes da ciência 
conseguiram sair do discurso regulamentar e dominante da ciência e recontextualizá-lo, torná-lo acessível ou transmiti-lo de forma diferente? A análise das interações demonstrou que existiu essa dificuldade. A ciência e seus representantes se mostraram dependentes de gráficos, tabelas e apresentações. Fazer associações, trazer esse conhecimento para a prática cotidiana ainda é uma barreira a ser transposta. O diálogo, a conversa, não aconteceu. Não se pode dizer que a esfera científica é a única responsável por isso. As condições da dinâmica, do local da prática, contribuíram para tal. Ao instalar duzentos estudantes adolescentes em um auditório, é óbvio que é necessário o estabelecimento de regras para que o dispositivo funcione. É necessário criar a dinâmica e, ao mesmo tempo, instaurar a ordem. Debatedores e estudantes precisaram de tempo para sair de suas zonas de conforto e dar início à interação. Mas por que é tão difícil falar sobre ciência sem caracterizar uma situação de sala de aula ou de conferência? Por que é difícil interessar e engajar o público?

O discurso que emerge nos contextos dos "Cafés" é um discurso pedagógico que tem como pretensão transmitir alguma coisa a alguém e reflete as relações de poder de que fala Bernstein (1990). Mesmo que as dificuldades apareçam, seus contextos buscam dar voz a diferentes esferas da sociedade, valorizam seus saberes e especificidades e, mais ainda, são espaços facilitadores de trocas culturais através da participação dos atores envolvidos.

Surgiu uma questão: esses mesmos conceitos se comportariam da mesma maneira no "Barômetro - ciência, café e debate"? Pode-se dizer, de início, que surgiram algumas diferenças, embora ambos os conceitos se apliquem perfeitamente, e que essas diferenças residiram nas particularidades de cada evento.

O segundo contexto, o Café des Techniques apresentou, da parte de sua equipe organizadora, a preocupação de convidar para os debates profissionais de áreas diversas e não somente profissionais da área das ciências. Ao longo dos seus dez anos de existência, houve o trabalho incessante de formação de público (uma média de 80 pessoas por evento) e o cuidado de abordar temas não somente diversos, mas próximos da vida cotidiana. Na noite da coleta dados, o tema foi a internet com uma abordagem bem interessante - "O direito ao esquecimento na internet é possível?" (tradução nossa), com um público presente de 120 pessoas. A participação do público foi pequena diante do grande número de participantes e do 
empenho do animador, o jornalista científico, em ir até a audiência e se locomover entre ela para buscar candidatos a perguntas. Conforme foi dito, ainda no hall de entrada no museu, estavam todos lá para assistir a uma conferência.

A concepção do terceiro contexto levou em conta, além das informações levantadas pela pesquisa documental, os aspectos levantados nos dois contextos anteriores. A presença de representantes de comunidade científica e da sociedade civil, a presença e a participação do público de maneira mais interativa do que os contextos anteriores, a seleção de temas que estabelecessem relações com 0 cotidiano, enfim, uma forma mais dinâmica para promover o diálogo entre a ciência e a sociedade.

Sem levantar as diferenças entre ambos os contextos, pode-se dizer que o segundo e o terceiro se encaixaram no modelo de engajamento público de Lewestein (2003). Isso não indicou que eles não pudessem se encaixar nos outros modelos, o próprio autor falou que, na prática, muitas das atividades de comunicação pública da ciência combinam aspectos dos quatro modelos.

O que teve de ser considerado até aqui foi a mobilização de pessoas que esses contextos conseguiram reunir de maneira significativa, como foi o caso do café do CNAM, embora não tenha sido possível saber maiores detalhes sobre seus participantes. Mas a amostra e a média de público foi um fator também a ser observado pela equipe do "Barômetro". Para o autor, os tipos de engajamento podem ocorrer de formas diversas desde que seja possível observar ou até mesmo mensurar o tamanho dos grupos e o número de pessoas envolvidas, o grau de deliberação que esses grupos oferecem, a existência de forças, as atitudes expressadas por eles e as habilidades para agir. Os resultados gerais do estudo de público do "Barômetro" e o estudo detalhado se encontram no Anexo D. Em relação aos outros fatores, que para o autor caracterizam os tipos de engajamento, as análises das interações levantaram mais evidências.

Uma série de atividades diversas é contemplada nesse modelo que podem ser impulsionadas pelo compromisso com a "democratização" da ciência que, na concepção do autor, tira o controle da ciência dos cientistas e políticos e entrega para grupos públicos através de alguma forma de engajamento político. A presença do compromisso com a democratização da ciência nos Cafés Científicos esteve presente desde a pesquisa documental. Tirar o controle da ciência dos cientistas e políticos não pareceu estar inserido em seus propósitos. O que realmente se quer é 
criar a aproximação de esferas da sociedade que geralmente não se encontram frente a frente para dialogar entre si. A dimensão política se encontrou arraigada nesses encontros porque os representantes de ambas as esferas são, acima de tudo, cidadãos. A questão política ou o engajamento político é uma necessidade social, não pensando na política somente relacionada aos cargos públicos e partidos políticos, mas nas atitudes de cada um e no exercício da cidadania.

Lewestein (2003) colocou a linguagem como elemento central pois existe a necessidade de entendimento na sociedade sobre o que a linguagem dos pesquisadores e dos designers de projetos quer dizer. Ele citou a proliferação dos projetos "cidadãos/ciência" que combinam educação, pesquisa e certo grau de entretenimento. Linguagem, educação, pesquisa e entretenimento são quesitos que se encaixam perfeitamente nos Cafés Científicos, não importa qual seja a modalidade. $E$ todos esses quesitos foram cuidadosamente trabalhados no projeto "Barômetro".

Quanto aos projetos, o autor falou do engajamento de estudantes e amadores e do fornecimento de dados, da parte deles, para a comunidade científica ou para seus próprios usos. Projetos como os Cafés Científicos estão abertos para toda a comunidade, embora a pesquisa documental tenha revelado uma forte ligação com a academia de maneira geral, seja no Brasil, seja no exterior. A relação entre ciência e sociedade é fortemente mediada pelos estabelecimentos acadêmicos, por mais não acadêmicos que eles desejam ser. A lacuna entre ambos pode residir na falta do diálogo ou na falta de habilidade para se exercer esse diálogo. Esse foi o espaço que seus idealizadores procuraram preencher.

O processo de concepção do "Barômetro - ciência, café e debate" tocou justamente nessa tecla. Promover o diálogo entre esferas da sociedade aparentemente afastadas entre si, através de formas alternativas que procuraram se distanciar das, como diz Bernstein (1990), formas de comunicação extremamente especializadas que acontecem nas escolas ou nas universidades. Assim como o autor, cuja análise teve como foco a lógica interna do discurso pedagógico, as análises discorreram de forma a procurar entender a lógica interna desse diálogo através das interações ocorridas durante a transmissão dos programas. O contexto do "Barômetro", em particular, foi submetido aos elementos geradores que provocaram as interações e que possibilitaram refletir sobre as relações de comunicação que podem existir, ou não, entre essas esferas da sociedade. 
As regras definidas por Bernstein (1990) - distributivas, de recontextualização e avaliativas - embora presentes na organização dos três contextos, aconteceram de forma diferenciada entre eles.

Segundo Bernstein (1990), as regras distributivas estabelecem uma relação entre poder e conhecimento e entre conhecimento e consciência. Elas consideram os opostos - o sagrado e o profano, o esotérico e o mundano, o pensável e o impensável, em uma situação de alteridade, ou seja, elas especializam o impensado para certos grupos e o pensado para outros. Para ele, tanto as sociedades compartilham um tipo particular de abstração que vincula o material com o imaterial, que cria uma relação que acaba por relacionar um mundo com o outro. Para o autor, essa abstração gera uma brecha que abre possibilidades alternativas, algo diferente da prática cotidiana, que ele denomina de abertura discursiva. Esta é o lugar para o impensável, o impossível. Bernstein (1990) sustentou que nem todos têm esse acesso a essa abertura e as regras distributivas regulam aqueles que têm acesso a esse lugar. Elas marcam e distribuem quem pode transmitir o que, a quem, sob quais condições e sujeitos aos limites internos e externos do próprio discurso pedagógico.

Tanto o segundo quanto o terceiro contexto ilustraram as colocações do autor. E por maior que tenha sido o esforço, no terceiro contexto, de inserir no seu quadro de debatedores representantes da sociedade civil das mais diversas esferas do conhecimento e dar voz a seus representantes, o roteiro, o ambiente, o formato "programa de rádio" e a condução dos debates acabaram por regulamentar os discursos proferidos. Outro fato foi que a abertura que se tentou criar em ambos os contextos - cidadãos de áreas diversas que não somente as da ciência para discutir sobre temas da ciência - acabou por "selecionar", dentro dessas áreas, seus respectivos representantes. A produção do discurso se inseriu em um campo especializado, com regras especializadas de acesso e de controle de poder. $O$ ambiente descontraído, fora de espaço acadêmico para se discutir sobre ciência acabou por reproduzir, de certa forma, aquilo que ele tenta evitar. No entanto, por mais regulamentar que tenham sido os discursos, o terceiro contexto, o Barômetro, promoveu a participação do público de forma mais efetiva e buscou maior equilíbrio entre as partes envolvidas, ainda que a voz de seu público tenha sido veiculada através de outro, ou seja, os repórteres da rádio, seus mediadores, e segundo suas escolhas em relação ao que foi repassado para os debatedores. A participação do público participante frente a frente com os debatedores foi pequena. 
As regras de recontextualização deslocam o discurso de seu local de prática e Ihe conferem nova ordem. Elas constroem o discurso pedagógico cujo aspecto dominante é o discurso regulamentar que produz a ordem do discurso instrucional. Por mais que os contextos de Cafés Científicos tenham a intenção de conceber novo espaço para recontextualizar o conhecimento científico e, quem sabe, desconstruir ou construir outros discursos, essa tarefa fica às vezes um pouco difícil porque os discursos produzidos e circulados se originam daqueles que vieram dos contextos com os quais se deseja, nesse novo espaço, estabelecer a ruptura. Os representantes da comunidade científica de todos os três contextos analisados têm sua trajetória profissional desenvolvida dentro do ambiente acadêmico e ficou difícil para eles não reproduzirem suas práticas em outros contextos. Os representantes da sociedade civil, não importa o grau de escolaridade, supõem e/ou agem como quem vai debater com alguém que traz consigo não somente determinado conhecimento sobre o tema, mas um nível de conhecimento que, possivelmente, vai além do seu. Uma relação de poder é instaurada e fica fácil estabelecer a ordem, regulamentar. Mesmo assim o formato concebido pelo "Barômetro" conseguiu novamente estabelecer seu diferencial. Os representantes da comunidade científica foram levados a desconstruir suas práticas habituais de transmissão e comunicação de conhecimentos ao entenderem, na maioria das vezes somente no local do debate, que não iriam proferir uma aula, uma palestra ou uma conferência.

As regras de avaliação criam a prática pedagógica que constrói o texto que, conforme Bernstein (1990), é especializado e o coloca em relação com um tempo especializado e com um espaço especializado. A relação texto, tempo e espaço ficou latente em todos os contextos. Para o segundo contexto, essa relação lhe conferiu o que os funcionários do CNAM e as pessoas que estavam na fila falaram no momento anterior ao debate, um "ar" de conferência. Para o terceiro contexto, seria impossível fugir de seu formato previamente determinado e planejado, um programa de rádio. E esse formato também possuiu seu próprio discurso, sua forma peculiar de se manifestar, lembrando aqui de seu compromisso com a formação de alunos de diversos cursos da universidade à qual a rádio pertence.

Mas a ligação com o tempo e o espaço também chamou a atenção em relação a todos os outros contextos de Cafés Científicos comparados na pesquisa documental. Discutir sobre ciência requer, na concepção de seus organizadores, um tempo regulamentado, que não deve ultrapassar determinado tempo, intercalado por 
intervalos de tempo, para que o discurso não fique enfadonho, cansativo, que não desgaste o público e que não interfira na descontração do ambiente que se pretendeu instaurar. Mais ainda, que garanta o retorno desse público e que faça dele um frequentador e não apenas um participante ocasional.

As análises a seguir foram trabalhadas no sentido de esclarecer as proposições demarcadas pelo campo teórico.

\subsubsection{A Esfera Semântica — os elementos geradores da interação}

O software da Esfera Semântica armazenou palavras dos campos semânticos da ciência e dos temas debatidos. Foram essas palavras um dos principais elementos geradores das interações durante os debates. Quando houve algum tipo de restrição, foi em relação ao funcionamento e à capacidade de armazenagem do software que podia contar com o mínimo de 80 e o máximo de 120 palavras. Nesse caso, foi necessário fazer uma varredura, o próprio programa possuía esse sistema, segundo alguns critérios de eliminação: palavras com raízes semelhantes (por exemplo: estudo/estudioso), palavras compostas, adjetivos. A opção recaiu sobre o substantivo.

O software gerou, para cada programa, tabelas que continham as combinações de palavras e as respectivas perguntas ou comentários originários das combinações. Das tabelas, foi possível relacionar uma série de dados (APÊNDICE A) como:

- Número de combinações de palavras $X$ ocorrência das palavras;

- Ocorrência e combinações de palavras por campo semântico (ciência e tema) e o cruzamento entre os campos semânticos (ciência $X$ tema);

- Categorização das perguntas / comentários apresentada nas Tabelas de Categorias;

- Abordagem emergencial das interações.

Os dados relacionados no Apêndice A correspondem ao evento do mês de abril de 2011 - Ciência e Dengue.

Do programa escolhido para análise, as perguntas selecionadas pela equipe da rádio ( $A P E \hat{N} N I C E B$ ) que se tornaram públicas nos eventos se integraram às palavras da esfera como os próximos elementos geradores da interação, a seguir: 
- as perguntas feitas através do microfone pelo público participante;

- as respostas e os posicionamentos dos debatedores.

\subsection{Análise II}

A segunda parte da análise se desenvolveu a partir das interações ocorridas no segundo evento do "Barômetro - ciência, café e debate" que tratou do tema Ciência e Dengue. As interações foram transcritas no Quadro de Narrativas (no CD entregue junto com a tese) e correspondem à transmissão em tempo real da edição do projeto que foi ao ar no dia 14 de abril de 2011. Esse programa teve a duração de 83 minutos, 7 minutos menos do que o tempo previsto. O Quadro de Narrativas contém a transcrição do Barômetro Ciência e Dengue.

Foram submetidas à análise, as perguntas e comentários do público participante e as respectivas respostas dos debatedores do programa "Ciência e Dengue". As perguntas e/ou comentários tiveram sua origem nos campos semânticos disponíveis nos tablets. $O$ foco da análise se centrou nas respostas proferidas pelos debatedores representantes da comunidade científica e representantes da sociedade civil, segundo procedimentos e abordagens da Análise Temática.

Conforme indicado pela hipótese, a análise buscou nas respostas dos debatedores elementos que indicaram imagens e posicionamentos relacionados à ciência.

\subsection{Análise temática}

A análise temática foi o procedimento escolhido em função da natureza das interações e da hipótese de pesquisa proposta. Seus procedimentos permitiram melhor organização do material transcrito pela divisão dos conteúdos das interações em temas e subtemas, o que facilitou a caracterização do contexto e a categorização das imagens da ciência.

Segundo Riessman (2007), toda investigação narrativa está preocupada com o conteúdo - "o que" foi dito, escrito ou visualmente mostrado, mas para a análise temática o conteúdo é o foco. Em outras palavras, essa abordagem de análise permite que o mais simples e atraente em contextos complexos e complicados possa emergir. A autora comparou seus procedimentos aos dos historiadores quando 
trabalham com arquivamento de dados e colocou que seu objeto de estudo reside em como analisar tematicamente materiais narrativos. Seu objetivo é explorar práticas concretas ou formas de tratar dados narrativos onde a atenção primeira está no "que" foi dito e não em "como", "de quem" ou "com que propósitos".

A abordagem temática pode ser aplicada em uma vasta variedade de textos narrativos, em entrevistas, conversas de grupos, documentos escritos, entre outros. Modelos diversos ilustram quais os efeitos que determinadas narrativas podem ter, além dos significados individuais de quem as narrou, abrindo possibilidades para revelar identidades sociais, pertencimentos de grupos e ações coletivas. Os dados são interpretados à luz das temáticas desenvolvidas pelo investigador.

Riessman (2007) propôs um desenho que começa com as questões que estruturam um estudo, que são: como o conceito de narrativa está sendo utilizado; como os dados foram construídos para a análise com atenção para a linguagem e a forma; a unidade de análise de cada investigação; e, a atenção do investigador para os contextos, tanto local quanto social, nas dimensões micro e macro.

A pesquisa sobre esse tipo de análise evidenciou que é um procedimento muito utilizado na área da saúde em geral e na área da psicologia em particular. $\mathrm{O}$ posicionamento de Aronson (1994) ilustrou essa situação. Segundo o autor, das conversas que surgem nas sessões de terapia ou de outras que estão submetidas a esse tipo de análise, as ideias que emergem podem ser mais bem entendidas sob o controle da análise temática porque ela vai focar em temas que identificam padrões de comportamento e de vida. Das transcrições das conversas e das interações, padrões e experiências podem ser relacionados.

Os procedimentos de Aronson (1994) seguem a seguinte sequência: dos relatos das experiências os primeiros padrões são estabelecidos; o próximo passo é identificar os dados que se relacionam com esses padrões; feito isso chegou o momento de combinar e catalogar os padrões relacionados em subtemas. Os temas são definidos como unidades que derivam dos padrões tais como "tópicos de conversação, atividades recorrentes, sentimentos, significados, provérbios, ditos populares". Os temas são identificados como o elemento que reúne fragmentos ou ideias ou experiências, os quais são frequentemente identificados como sem significado ou sem sentido quando analisados de forma isolada. Os temas que emergem das falas são peças que, quando reunidas, formam a compreensão do quadro das experiências coletivas. Os subtemas, quando reunidos para se obter a compreensão das 
informações, facilitam a visão dos padrões que emergiram. O autor lembrou que é necessário construir um bom argumento para a escolha dos temas. Uma vez que os temas foram construídos e a literatura foi bem estudada, o investigador está pronto para formular afirmações em torno deles e desenvolver suas constatações.

Baddredine, Buty e Nascimento (2007), cujo processo de análise temática teve como foco a análise do discurso em sala de aula de ciências em sua definição de episódios, tiveram como ponto de partida que um tema representou um sujeito central na discussão em sala em um intervalo de tempo dado. Como para eles o professor é responsável tanto pela gestão do conteúdo como pela gestão da evolução dos saberes na sala de aula, o tema é, em geral, introduzido pelo professor. Isso não descartou o surgimento de um novo tema da parte dos alunos. Os autores explicaram que determinadas marcas nas palavras do professor podem indicar o surgimento de um tema, por exemplo: então, em seguida, retomemos a isso, entre outros. Mas existem também outros indícios como a introdução de um capítulo do livro didático ou a retomada de uma atividade e assim por diante. Eles querem dizer que essas marcas podem delimitar um tema embora não indiquem uma mudança de tema, porque, conforme esses autores, os critérios semânticos devem ser sempre preponderantes.

Os três autores definiram como subtemas os conteúdos que o professor utilizou para auxiliar a construção do tema ensinado durante a aula, em função do desenrolar das aulas ou das situações imprevistas em decorrência da relação ensino e aprendizagem. Para eles, um tema ou um subtema pode ser previsto ou não pelo professor e os subtemas que surgem podem se relacionar de forma mais ou menos interligada. A sala de aula é um ambiente dinâmico e fica impossível prever o acontecimento dos fatos. As fases de trabalho em sala de aula vão proporcionar diferentes articulações entre as unidades temáticas - os temas e os subtemas. A contribuição desses autores residiu no fato de que, através desse procedimento de análise, foi possível verificar a importância que têm as mudanças de conteúdo temático na sala de aula interacional, quando elas se tornam visíveis para os alunos pela estruturação do discurso de forma articulada com esses saberes.

Bardin (2011) apontou a análise temática como contagem de um ou vários temas ou itens de significação em uma unidade de codificação determinada anteriormente. Essa unidade de codificação pode ser uma frase que compõe o discurso, desde que limitada por dois sinais de pontuação (entre aspas). 
Esse tipo de análise possibilita a verificação inicial das hipóteses que são, posteriormente, submetidas a uma análise mais pormenorizada. Ela denominou essa fase de desmembramentos temáticos que se multiplicam e são classificados e divididos segundo as significações do discurso em categorias, em que os critérios de escolha e de delimitação são orientados em função dos objetivos pretendidos.

Prosseguem considerações a respeito do contexto das interações.

\subsubsection{O contexto das interações}

A análise teve como ponto de partida, portanto, os dados obtidos pela interação do público com a Esfera Semântica.

O público presente no Barômetro Ciência e Dengue contabilizou 37 pessoas. Do total de combinações de palavras enviadas pelos tablets, o público participante enviou 76, seguidas ou não de perguntas e/ou comentários. Foram consideradas válidas as combinações de palavras acompanhadas de perguntas e/ou comentários. Para a análise, foram levadas em conta as perguntas e/ou comentários que se tornaram públicas no decorrer do evento. Aliadas a esse conjunto, somaram-se as perguntas feitas pelo microfone durante o programa.

Não houve tendência, por parte do público participante, de utilizar mais palavras de um campo em relação a outro. O público conseguiu transitar entre os campos semânticos, sem discriminá-los, para elaborar seus questionamentos ou comentários.

Foram perguntas, comentários e respectivas respostas oriundas dos debatedores que geraram a linha de condução dos debates. Esses acontecimentos se deram de forma independente à abordagem proposta pela equipe de concepção do "Barômetro".

Para o evento Ciência e Dengue, o público foi convidado a debater sobre as campanhas de combate à dengue, a compreender o papel da ciência e da sociedade nessa luta. As perguntas e os comentários enviados levantaram dúvidas, mitos, saberes populares, dentre outros, que refletiram as reações da sociedade diante de uma doença que tem ao seu redor aspectos controversos, principalmente da parte da ciência. Diante das próprias dificuldades da ciência em lidar com o assunto e da necessidade do governo de criar campanhas de combate sem que aparentemente exista um diálogo entre essas instâncias, a sociedade buscou soluções alternativas, oferecendo, muitas vezes, riscos à sua saúde. 
Nesse sentido, as interações ocorridas nos debates de forma geral geraram um material rico, principalmente, as do evento aqui analisado.

\subsubsection{Capital de fala}

É interessante analisar outro elemento no decorrer do processo, que é o Capital de Fala, ou melhor, os tempos de fala das partes envolvidas. Nascimento (1999), em consenso com outros autores, explicou que o capital de fala corresponde às sequências que exprimem o número de turnos de fala dos sujeitos na interação. Foram considerados como "partes envolvidas" os debatedores da ciência e da sociedade, os repórteres da rádio - apresentador e mediador, o público participante a as apresentações musicais. Os capitais de fala podem indicar o quanto dialógica uma interação pode ser através da participação equilibrada ou não de suas partes. É preciso salientar que o debate foi mediado e que boa parte das perguntas vindas do público participante foi transmitida pelos repórteres da rádio, fato que assegurou certa representatividade desse público sem que ele mesmo o fizesse. O público foi "protegido" pelo recurso dos tablets e pela "sorte" de ter suas perguntas selecionadas ou não.

Dessa maneira, o capital de fala nessa interação assumiu outra conotação que não os turnos de fala. Segue Quadro 10, que relacionou o Tempo e o Capital de Fala da cada participante do "Barômetro" Ciência e Dengue.

Quadro 10 - Relação Tempo x Capital de Fala dos participantes do "Barômetro" Ciência e Dengue

\begin{tabular}{|l|c|}
\hline \multicolumn{1}{|c|}{ Tempos de fala (em minutos e segundos) } & Café 2 \\
\hline Apresentadora da rádio & $12^{\prime}$ \\
\hline Apresentação musical & $23^{\prime *}$ \\
\hline Debatedor comunidade científica - médico & $28^{\prime}$ \\
\hline Debatedor sociedade civil - dona de casa & $8^{\prime}$ \\
\hline Debatedor sociedade civil - diarista & $7^{\prime}$ \\
\hline Repórter tablet (perguntas tablet e público participante) & $9^{\prime}$ \\
\hline Institucional & $8^{\prime} 20^{\prime *}$ \\
\hline Tempo total & $8^{\prime}$ \\
\hline
\end{tabular}

Fonte: Elaborado pela autora.

Nota: * Na noite de transmissão dessa edição, foi transmitida a propaganda política obrigatória na rádio e ocorreu uma pequena interrupção técnica, por isso, o grupo musical e a transmissão institucional tiveram tempo maior do que o previsto no script.

Do tempo total, o debatedor representante da comunidade científica falou 
durante cerca de $34 \%$ do tempo. O restante do tempo ficou dividido entre os representantes da sociedade civil, que falaram durante praticamente a metade do tempo do debatedor da ciência, $17 \%$ do tempo (nessa noite, foram dois debatedores da sociedade), as repórteres da rádio, o público participante e as apresentações musicais.

A concentração do tempo no representante da comunidade científica demonstrou que, embora os repórteres da rádio buscassem equilíbrio na participação das partes, três fatos puderam ser levantados. O panorama dos quatro primeiros eventos permitiu o levantamento dessas constatações. No evento escolhido para análise, ele se repetiu de maneira intensa.

Primeiro, provavelmente, os representantes da comunidade científica, pelo fato de pertencerem à academia e são, além de pesquisadores, professores, tenham o hábito de falar para uma audiência. Segundo, que eles são especialistas em suas áreas de atuação. Terceiro, por mais que se procurasse fazer com que as partes participassem de forma mais equilibrada, as perguntas, principalmente no debate Ciência e Dengue, tenderam a se dirigir para os debatedores da ciência. Tanto os esclarecimentos trazidos por eles quanto as opiniões emitidas tinham, aparentemente, o poder de respaldar as colocações e as dúvidas, seja do público, seja dos repórteres da rádio. Das dez primeiras perguntas no Café Ciência e Dengue, seis foram direcionadas para o debatedor da ciência contra quatro direcionadas para as duas debatedoras da sociedade, três para a dona de casa de classe média e apenas uma para a diarista. No geral, o capital de fala ficou concentrado nas mãos dos debatedores representantes da comunidade científica que, em algumas situações durante os debates, tenderam a se comportar de forma monológica, por mais dialógicos que gostariam de ser. A pesquisa começou a evidenciar seus resultados.

A análise do Capital de Fala se complementou e fez sentido após o exame mais detalhado das interações.

\subsubsection{Análise das interações com a Esfera Semântica - do virtual para a oralidade e o discurso radiofônico / o espaço público e o espaço privado}

As palavras foram fornecidas para o público participante através do suporte digital - software/esfera semântica/tablets - que implicaram em uma construção discursiva próxima da linguagem digital, e esse foi o formato enviado para os repórteres/mediadores da rádio. Esses, por sua vez, selecionaram e se apropriaram 
das perguntas e as remodelaram através dos recursos da linguagem radiofônica. A mediação digital e radiofônica proporcionou uma trajetória que remodelou as perguntas enviadas - do meio digital para a oralidade, em outras palavras, da pratica discursiva típica do meio digital, ainda no espaço privado, para a projeção das mesmas no espaço do debate, o espaço público. Logo após, eram selecionadas pelos repórteres da rádio, novamente no espaço privado, para voltarem ao espaço público, pela oralidade, remodeladas pelos recursos da prática discursiva radiofônica.

A apresentação recorrente dos debatedores - característica da transmissão radiofônica - do tema debatido na noite, da esfera semântica e os tablets, dos informes do horário, entre outros, pelos repórteres da rádio, transportou o ouvinte ao ambiente do debate através do discurso e não da imagem. A imagem se fez presente no momento da divulgação dos eventos, sempre anterior aos debates. Esse recurso de repetição de fala sugere o ambiente para o ouvinte e dá ênfase a essa mídia que não se utiliza de imagem, mas, pelo contrário, sugere imagens através de recursos sonoros e discursivos.

Segundo informações obtidas no blog Formação Cidadã/Oficina/Comunicação Popular, a fala é o instrumento central da radiodifusão. O apresentador de um programa, de rádio ou de televisão, depende do bom uso que faz de sua capacidade de expressão vocal. Neste ponto, inseriu-se a dimensão formadora da rádio da universidade, em que projetos como o "Barômetro" funcionaram como uma espécie de laboratório de treinamento para os alunos em geral e, em especial, para os alunos do curso de comunicação. Falar ao microfone é uma atividade que exige técnica apurada, nessa a significação do texto está intimamente relacionada à forma como ele é lido. Uma frase pode adquirir diferentes conotações quando dita em diferentes contextos ou mesmo quando não se utiliza corretamente a pontuação. Para o radialista Ruy Jobim, diretor da Escola de Rádio, a voz não está acima da comunicação. O bom locutor precisa saber transmitir a mensagem de forma fácil, simples e imediata, não é necessário ter uma voz bonita, mas utilizar de forma adequada sua capacidade vocal. Ele precisa dar o tom adequado ao que é dito, dar forma à expressão, mudar a entonação, fazer pausas. Sua voz é seu instrumento de trabalho.

A seguir, considerações sobre o que nesta pesquisa foi delimitado como espaço público e como espaço privado. Esses termos, trazidos e adaptados do projeto “Débats, Diversité et Développement Durable - Le café scientifique Junior dans l'enseignement DD dans diverses cultures" (LE MAREC, 2010) correspondem a 
momentos distintos das práticas discursivas nos Cafés Científicos.

Espaço privado foi entendido, nas proposições do referido projeto, como o momento de negociação e discussão entre os alunos em seus grupos e correspondem às conversas que não se tornaram públicas no debate. Foram dois momentos de espaço privado nas interações do Barômetro. O primeiro, entre o público participante e os tablets, onde as perguntas ora foram elaboradas individualmente, ora em colaboração com amigos e outros participantes que estavam por perto. O segundo, aconteceu entre a "repórter tablet" e seus assistentes que anotavam e selecionavam as perguntas projetadas e decidiam, no momento da transmissão, quais perguntas se tornariam públicas.

O espaço público correspondeu ao que foi dito sem trazer, necessariamente, tudo o que foi negociado no momento íntimo das discussões. O espaço público aconteceu em três momentos distintos e teve início com a projeção das palavras na esfera semântica. As palavras escolhidas pelo público e enviadas sob a forma de perguntas retornavam ao espaço público também pela projeção. Quando a pergunta era selecionada, ela tornava a retornar ao espaço público pela oralidade.

O fluxo de elaboração das perguntas e suas distribuições entre os espaços público e privado se apresenta abaixo na Figura 8:

Figura 8 - Esquema do Fluxo de elaboração das perguntas e suas distribuições entre os espaços público e privado

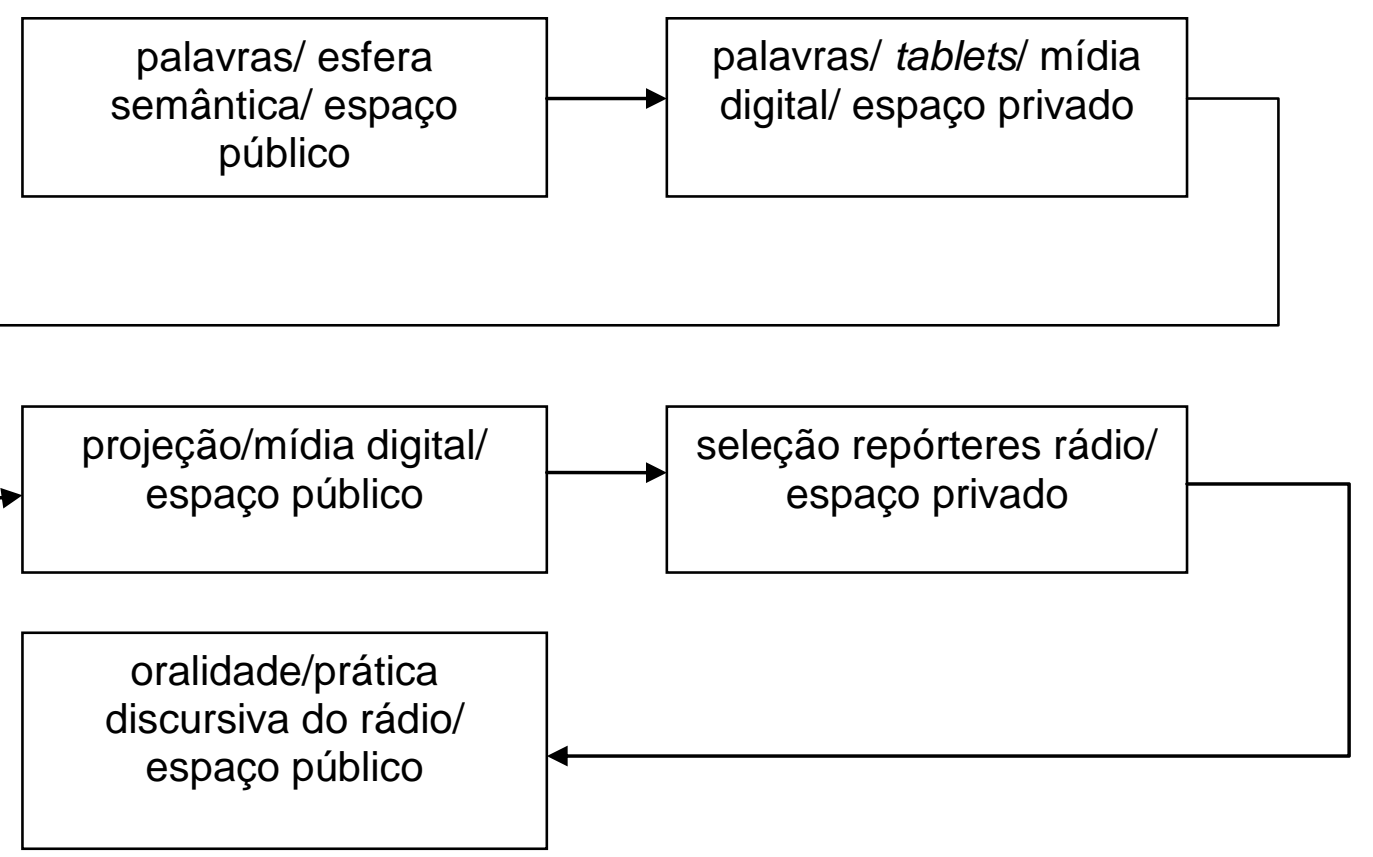

Fonte: Elaborado pela autora. 


\subsubsection{Análise das interações - temas e subtemas}

A análise das interações buscou indicadores que fizessem referência ao contexto de produção da ciência, suas formas de validação e comunicação, de um lado, e do outro, como a sociedade compreende, faz uso ou não do conhecimento científico, cria seus mitos em relação a esse conhecimento e se utiliza dos saberes populares quando não encontra respostas na ciência.

Os quatro primeiros programas do Barômetro foram transcritos. Logo após, foi realizada uma escolha de qual desses programas seria detalhadamente analisado com a finalidade de encontrar esses indicadores.

Uma vez selecionado o programa, o processo de demarcação de temas e de subtemas teve início.

A construção e proposição dos temas foi um processo difícil face ao volume do material - para esta análise foram 83 minutos de transcrições do Quadro de Narrativas do "Barômetro" Ciência e Dengue. O conteúdo das transcrições permitiu o levantamento de um material rico para a pesquisa, o que dificultou as escolhas de determinados trechos em detrimento de outros.

Bossler (2004) fez uso do termo "desempacotamento" que, para ela, indica um percurso discursivo. Em função desse percurso discursivo, os trechos analisados foram selecionados. O ponto de partida correspondeu às falas iniciais dos debatedores do "Barômetro" Ciência e Dengue e foram escolhidos justamente porque, além de situar as partes no debate, acabaram por contribuir no delineamento do debate como um todo. Os posicionamentos iniciais permitiram que viesse a público, primeiramente, as colocações desses debatedores diante do tema. Outro aspecto residiu no fato de que, como o material discursivo era volumoso, esse percurso acabou por traçar o desenho da análise.

Bossler (2004) indicou direções para esse "desempacotamento" que podem ir da horizontalidade à verticalidade, mas que podem também estabelecer um tipo de conexão formando uma espécie de rede de subtemas em torno de um tema central ou de mais de um tema.

\subsubsection{Retomar a hipótese}

A pesquisa documental sobre Cafés Científicos realizada para esta pesquisa trouxe definições simples e precisas a respeito do que se tratam esses eventos de 
comunicação pública da ciência. Praticamente em unanimidade, os Cafés Científicos são espaços fora do ambiente acadêmico que se configuram como lugar de encontro da comunidade científica com a sociedade civil para se discutir sobre ciência. Falou-se também em ambientes descontraídos onde os debates são acompanhados pela degustação de comidas e bebidas. O grande esforço dos idealizadores desses eventos foi o de procurar descaracterizar os ambientes estereotipados onde se discute sobre ciência. Ou, que discutir sobre ciência pode ser em qualquer lugar que não tenha a austeridade do ambiente acadêmico como característica central. E mais ainda, que todos podem participar e não somente aqueles que pertencem à academia.

Esse foi o ponto de partida para a construção da hipótese desta pesquisa com base nos fatos acima, esta tese investigou interações em contextos de Cafés Científicos a partir da hipótese de que nesses espaços emergem imagens da ciência presentes tanto no discurso dos representantes da comunidade científica quanto da sociedade civil. Detalhadamente, por meio das interações discursivas públicas entre a comunidade científica e a sociedade civil, promovidas pelo dispositivo pedagógico multimodal criado pelo projeto "Barômetro - Ciência, café e debate", emergem elementos relacionados à produção, validação, difusão, comunicação, articulação e desenvolvimento da ciência de um lado e, elementos relacionados ao entendimento, apropriação, utilização, mitificação, aceitação, refutação, negação e discussão da ciência de outro. Esses fatores orientaram a construção das categorizações das imagens da ciência propostas nesta pesquisa, nos procedimentos de análise.

Dito isso, não se pôde dar início ao procedimento de análise sem antes caracterizar o contexto dos acontecimentos do projeto "Barômetro - Ciência, café e debate". As informações a seguir contêm fatos observados pela pesquisadora no dia a dia da produção do projeto e nas noites de debate que, na maioria das vezes, fugiram às regras, ao script, ao planejado. Mas, foram fundamentais para o entendimento do processo de construção da análise, seus temas e subtemas.

\subsubsection{O cenário das interações}

Os registros abaixo introduzem e ilustram o cenário das interações dos programas do "Barômetro Ciência, café e debate". Eles foram retirados do caderno de opiniões disponibilizado para o público participante a cada evento. 
Gostei do ambiente, do astral, da convivência diversa com várias idades, vários estilos, variedade [...]. Divulgação científica e tecnológica! Os tablets são geniais e, pelo menos pra mim, foi a primeira vez que pude 'brincar' com um! Adorei!

(Registro do caderno de opiniões Barômetro Ciência e Arte, 26 de maio de 2011.)

[...] Ambiente integrado, que convida plateia a interagir. É rico ver os estudantes universitários aprendendo na prática a profissão de locutores e repórteres de rádio, esse instrumento de prazer e aprendizado tão importante nas nossas vidas.

(Registro do caderno de opiniões Barômetro Ciência e Sala de aula, 29 de setembro de 2011.)

\subsection{Caracterizar o ambiente descontraído}

\subsubsection{As noites de debate no Centro Cultural}

Foto 10 - Barômetro Ciência e Samba, minutos antes do programa entrar no ar Sala do Piano, Centro Cultural UFMG

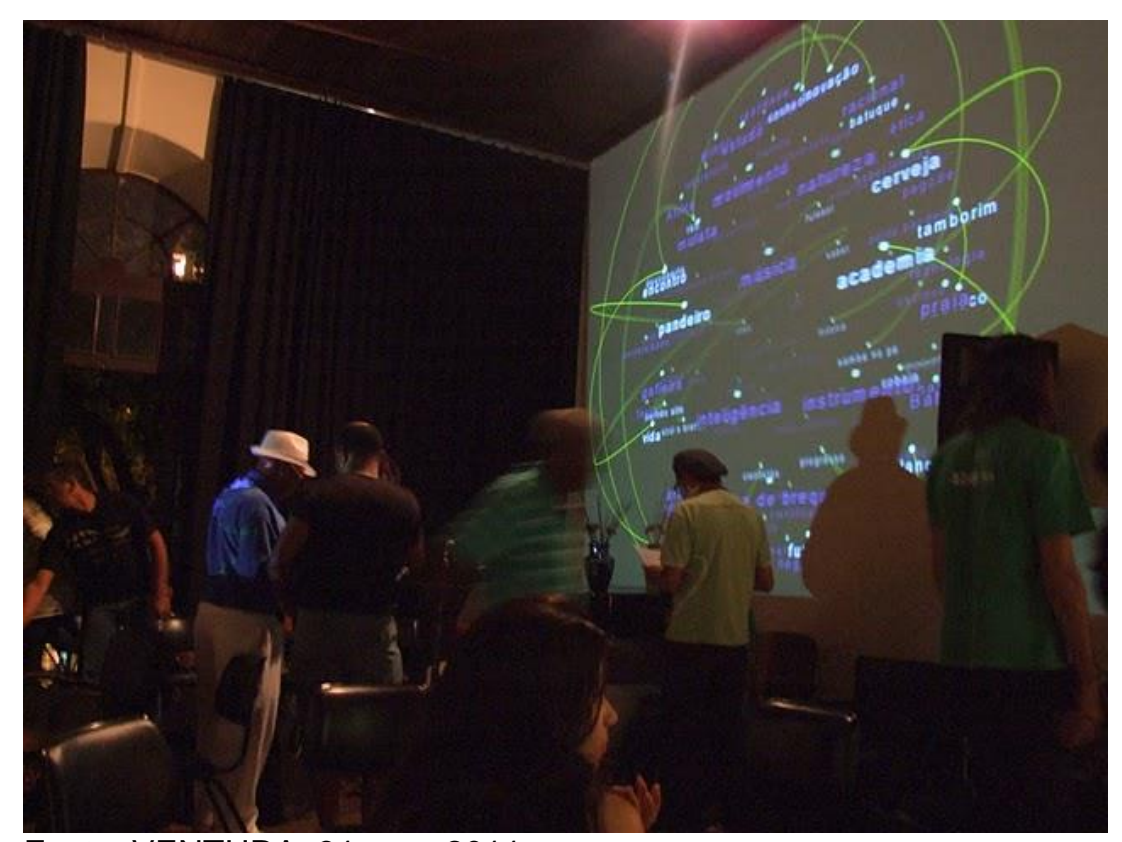

Fonte: VENTURA, 31 mar. 2011.

As noites de debate no Centro Cultural tinham início, na realidade, por volta das 14 horas das últimas quintas feiras de cada mês. A produção dos programas começava com a montagem do cenário que era composto pelo cartaz e pop card do evento do mês e pelas fotos do evento anterior. Uma das paredes da Sala do Piano se transformou em uma espécie de galeria da memória iconográfica do projeto (FOTO 11). Logo após, os móveis existentes no local eram redistribuídos e o espaço começava a se reconfigurar para receber debatedores, público, músicos, a equipe 
da rádio e a equipe de apoio técnico.

Uma hora antes de o programa ir ao ar, todos os atores participantes do processo já estavam presentes no ambiente e começava a primeira rodada de negociações. Questões como: qual debatedor seria chamado em primeiro lugar; qual o nome e a ordem das músicas que seriam apresentadas; como pronunciar determinados nomes; como funcionava a dinâmica do programa; eram discutidas entre a equipe de produção, debatedores e músicos. Em geral, era solicitado aos debatedores representantes da comunidade científica que iniciassem o debate. Essa solicitação vinha, principalmente, dos representantes da sociedade civil com a justificativa — "este é o/a especialista no assunto".

As dúvidas mais recorrentes vinham dos debatedores representantes da comunidade científica que justificavam, em sua maioria, o fato de não terem elaborado uma apresentação ou não terem preparado uma palestra ou uma conferência. Apenas no local, na Sala do Piano, ficava entendido que não havia a necessidade de preparar nada. A dinâmica e a estrutura do programa só eram incorporadas pelos debatedores da comunidade científica após a abertura do programa e a apresentação da equipe de repórteres da rádio. Esse foi um aspecto recorrente e que chamou a atenção.

Aos poucos o público chegava e se acomodava na sala, agora reconfigurada, com nova disposição dos móveis. E outras negociações começavam a acontecer. Onde se sentar? Com quem e perto de quem? O vai e vem do público se misturava entre se servir no buffet e aprender a manusear o tablet com as palavras da esfera semântica.

Às 20 horas e cinco minutos, o programa entrava no ar e daí para frente, apesar de toda a preparação e de um script cuidadosamente pensado, tudo poderia acontecer. A organização planejada poderia dar lugar tanto ao inesperado quanto ao lugar comum. Essa flexibilidade foi um dos diferenciais do projeto.

\subsubsection{A desconstrução de práticas - “chamar o cientista às falas"9}

Muito bom, me surpreendi com a descontração do ambiente e com a riqueza das perguntas. Além disso, o ambiente para os músicos é ótimo, nos deixa bastante à vontade. Eu havia me preparado para o evento mas 0

9 Prof. Dr. José Roberto da Rocha Bernardo, Universidade Federal Fluminense, em Junho de 2012, mencionou a expressão na banca de qualificação do presente documento. 
que eu disse não teve nada a ver com o que preparei, dada a descontração e a energia que rolou. Ótimo.

(Depoimento no caderno de opiniões Barômetro Ciência e Sala de aula do debatedor representante da comunidade científica e músico da noite -29 de setembro de 2011.)

Acho que é uma oportunidade legal para a reflexão, para socializar a informação e principalmente um momento de chamada para a ciência.

(Registro do caderno de opiniões Barômetro Ciência e Astrologia - 27 de outubro de 2011.)

Um Café Científico com formato de programa de rádio, por mais descontraído que procure ser, precisa seguir um roteiro com demarcações de início, meio, fim e intervalos. Para o "Barômetro", elaborou-se um formato, uma espécie de modelo, que pudesse balizar todas as edições. Esse formato foi cuidadosamente passado para os debatedores quando da negociação para suas participações nos debates. Em resumo, o programa consistia de três blocos de debate em torno de 20 minutos cada, alternando com as apresentações musicais. Por mais que isso fosse explicado, principalmente para os debatedores representantes da comunidade científica, o entendimento disso só acontecia com o programa já no ar.

Horas, minutos ou segundos antes do horário marcado para a chegada desses debatedores ao Centro Cultural UFMG, o telefone começava a tocar. A principal preocupação era - a não preparação de PowerPoint para a palestra, a conferência, a aula, seja lá o que for. Apesar de toda a explicação anterior sobre o formato e a dinâmica do rádio, um aspecto sempre surgia - a não preparação para participarem do evento. Houve uma noite em que o debatedor fez um comunicado pelo telefone, já na entrada do local do evento, desculpou-se porque não se preparou e, se fosse o caso, ele não entraria para participar do debate.

A não preparação para um evento que não possui o formato de aula, conferência, palestra ou outra prática acadêmica, deixava esses debatedores desconfortáveis. Da mesma forma, o ineditismo das perguntas também incomodava. As perguntas eram elaboradas na hora, durante a transmissão do programa, e ninguém tinha ideia sobre o que poderia acontecer. $O$ debatedor que se sentia mais à vontade declarava que tal pergunta ele não sabia responder. Às vezes, ele pedia ajuda ao colega debatedor da sociedade civil, vice e versa.

O mesmo incômodo em relação ao formato do programa não atingiu tanto assim os debatedores representantes da sociedade civil. 


\subsubsection{O público participante e a liberação da emissão}

Uma das formas de participação do público nos debates foi através da interface digital, ou seja, do software da Esfera Semântica e o manuseio dos tablets. O meio digital, não apenas estimulou a participação do público no debate, como acabou por criar um conjunto de gestos recorrentes nas edições do projeto.

A elaboração de perguntas através dos tablets fez com que um número significativo de perguntas fosse enviado para a projeção e provocou o que Lemos (2005) chamou de "liberação da emissão". Enviar perguntas em tempo real sem ter de se apresentar ao microfone garantiu conforto e anonimato para o público. $\mathrm{O}$ autor, que considera esse fenômeno uma das três leis da cibercultura, explicou que 0 as novas tecnologias de informação e comunicação permitiram a emergência de vozes e discursos antes reprimidos pela mídia de massa e agora liberados pela internet.

O "tudo pode na internet" trouxe nova relação entre tecnologias e sociabilidade e reconfigurou a cultura, as formas de comunicação e a circulação das informações. Uma amostra disso veio à tona durante as transmissões dos programas.

As palavras dos campos semânticos juntamente com o envio anônimo de perguntas para os debatedores, entre eles, cientistas, especialistas, experts, permitiram certa liberdade para questioná-los sem temer julgamentos e críticas sobre o que foi perguntado. O público pôde se expressar sem se constranger, sentirse inibido, inferiorizado ou coisa parecida.

O anonimato era timidamente denunciado pelo gestual. Enviar perguntas pelo teclado virtual do tablet significava acompanhar com os olhos a "aparição" das mesmas na projeção para verificar se realmente ela foi lançada para o espaço público. E, se a pergunta fosse escolhida pelos assistentes da "repórter tablet", o gestual se encarregava de denunciar o autor outra vez pela comemoração, às vezes solitária, às vezes com os colegas, em seu assento na Sala do Piano.

\subsubsection{Ciência e Dengue - O médico, a dona de casa, a diarista, o músico e o público}

Seria desnecessário dizer que cada debate foi especial ou que cada debate apresentou suas singularidades, suas sutilezas. Todos, com suas respectivas particularidades, tiveram seus momentos especiais. A escolha de um deles foi um ato difícil para quem esteve envolvido na organização, no cuidado e no preparo de 
cada um. Mas todo processo de pesquisa inclui esse ato de fazer escolhas, de fazer recortes, de focar. Dessa forma, não desmerecendo os demais eventos, debatedores e músicos, segue um relato sobre a noite em que Dengue e Ciência foram ao palco do debate no Centro Cultural.

O evento Ciência e Dengue ou "Vamos combater a dengue?" contou com a presença de um médico, professor universitário, uma dona de casa, moradora de um bairro de classe média, uma diarista, moradora de um bairro de periferia e um conjunto musical composto por moradores de uma comunidade da cidade de Belo Horizonte.

Os convidados presentes tiveram motivações particulares por parte da produção, assim como aconteceu nos demais eventos, para estarem presentes nesta noite. A data desse "Barômetro" saiu do calendário original, ou seja, última quinta-feira do mês, e aconteceu há exatos quinze dias depois do primeiro, devido a um problema de agenda.

O tema Dengue foi o foco das ações e levou a produção a buscar pessoas da sociedade civil que já tivessem havido algum caso de dengue na família ou na região em que mora, ou que habitassem em áreas de risco na capital. A escolha das duas debatedoras levou em consideração outro fator, enquanto uma é moradora de um bairro de classe média, bem assistido em termos de infraestrutura e saneamento básico, a outra é moradora de um bairro de periferia com condições precárias nesse sentido. A dona de casa do bairro de classe média já teve vários casos de dengue na família, dentre eles um caso grave e a diarista presenciou o filho pequeno da vizinha morrer de dengue hemorrágica, esse diagnóstico ficou pronto cinco dias após a morte da criança.

O grupo musical também foi cuidadosamente escolhido e seguiu dois critérios: primeiro, o fato de ter sido finalista de um projeto cultural que tem como objetivo valorizar a produção artística de moradores de comunidades da cidade de Belo Horizonte e, segundo, o fato de ser composto por moradores de uma comunidade, atualmente quase totalmente urbanizada, mas que ainda apresenta problemas de infraestrutura urbana como saneamento básico, iluminação pública e segurança, por exemplo.

Para completar o conjunto singular das pessoas presentes nesta noite, a Sala do Piano contou com a presença de uma turma de alunos de Educação de Jovens e Adultos (EJA) de uma escola municipal da capital que, após essa primeira experiência como público de um Café Científico, tornou-se frequentadora das 
próximas edições. Além dessa turma, apareceram estudantes de graduação, pesquisadores, professores e demais profissionais.

\subsubsection{Particularidades da noite}

Dentre as particularidades da noite, alguns momentos mereceram destaque. Um deles correspondeu à circulação, entre repórteres da rádio e o público participante, de um repelente caseiro levado pela dona de casa. Ela aprendeu a receita desse repelente em um programa de variedades na televisão. Segundo ela, a receita foi demonstrada no programa por um médico, que realizou testes diante das câmeras. Ela seguiu a receita, produziu o repelente em casa e, a partir daí, começou a fazer uso do mesmo. O fato curioso é que sua confiabilidade no produto se originou do fato de ter sido um médico que deu a receita no ar.

A outra ficou para a apresentação musical e a transmissão institucional obrigatória na rádio que gerou um intervalo de tempo maior do que o habitual durante o programa. Enquanto a transmissão institucional veiculava na rádio, o grupo musical prosseguiu, tocou no Centro Cultural e uma parte do público se levantou para dançar (FOTO 11). Ciência debatida com muita descontração.

Foto 11 - Público participante dançando no Barômetro Ciência e Dengue, Sala do Piano, Centro Cultural UFMG

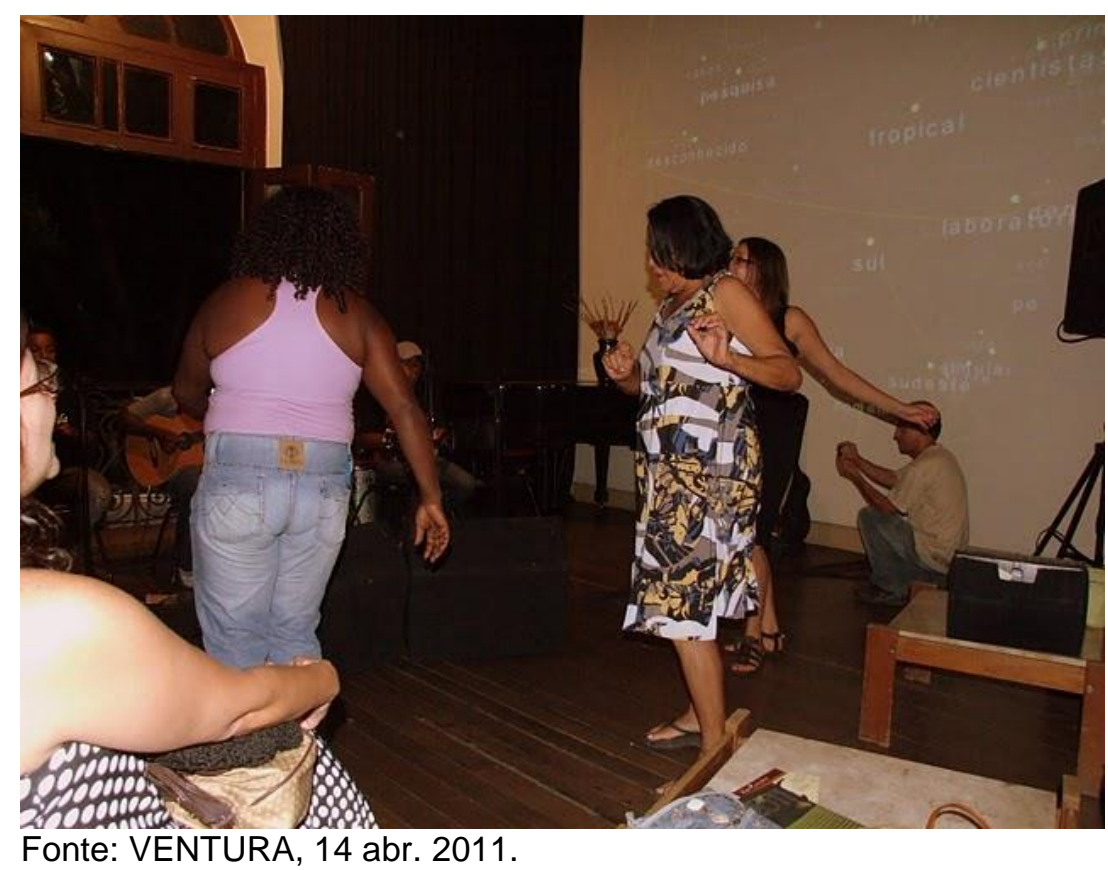

Ainda em relação ao grupo musical, o debate dessa noite teve a participação 
do vocalista não apenas como músico, mas como participante e mediador do debate em determinado momento da interação.

Por fim, a posição estratégica da projeção da esfera, bem diante dos debatedores, fato que gerou reação imediata no debatedor da comunidade científica. $\mathrm{Na}$ medida em que o público participante enviava as perguntas pelo tablet, elas ficavam prontamente enfileiradas no lado esquerdo da projeção e eram visualizadas por todos os presentes. Os assistentes da "repórter tablet" selecionavam as perguntas que Ihes chamavam a atenção e as repassavam para a mesma. Dessa maneira, nem todas as perguntas enviadas eram transmitidas aos debatedores e daí se originou uma das particularidades mais interessantes da noite.

O debatedor da comunidade científica, ao mesmo tempo em que respondia a pergunta que the era direcionada, prestava atenção na projeção e movimentava a cabeça de um lado para o outro inquieto. Ora ele queria ter respondido a pergunta que não foi feita publicamente, ora ele gesticulava em relação às perguntas que eram formuladas no instante. Em determinados momentos, ele se manifestou verbalmente em relação a isso no decorrer do programa.

\subsubsection{A comunidade científica e a sociedade civil}

Constituir o espaço físico, o ambiente ou o local de encontro entre cientistas e demais cidadãos é a tônica central dos Cafés Científicos e está mais do que declarado na totalidade dos sites afins. Mas basta um olhar pouco mais afiado para perceber que não se trata apenas de um encontro para um debate. Com todas as particularidades, desconstruções e inovações em torno desse encontro, os Cafés Científicos apresentam grande potencial como espaço para se refletir a respeito do fazer ciência e do que esse fazer ciência chega para a população e como chega.

Para os debatedores mais atentos, é um espaço para troca, para se voltar para o interior de suas próprias práticas e atitudes. E essa é uma das atribuições mais significativas para os Cafés Científicos - colocar frente a frente dois extremos de uma relação que pouco se sabe sobre as condições de sua existência.

\subsection{Caracterizar o ambiente multimodal}

Cada pessoa presente no Centro Cultural UFMG nas noites do "Barômetro Ciência, café e debate" ficou sujeita a vários tipos de estímulos e formas diversas de 
participação. Isso significou que debatedores, público participante, equipe da rádio, equipe do DDC e demais pessoas que transitaram na Sala do Piano visualizaram a projeção da esfera, escutaram a transmissão do programa, escutaram as apresentações musicais, visualizaram ou apreciaram o ambiente, visualizaram ou apreciaram o acervo da memória visual do projeto através das fotografias dispostas na parede e puderam, mesmo que não estivessem ali para participar do programa, enviar perguntas pelo tablet ou se servir no buffet. Os poucos mais desinibidos, atreveram-se a fazer perguntas pelo microfone.

Cada programa e seu respectivo tema tiveram suas particularidades. $O$ debate escolhido para análise de suas interações, Ciência e Dengue, foi selecionado devido a isso.

\subsubsection{A relação entre campos do conhecimento}

Para o ano de 2011, foi realizado um planejamento dos temas que seriam debatidos no "Barômetro". O critério inicial seguiu o calendário das manifestações culturais, religiosas, dentre outros, e foi se modificando na medida em que surgiram outras ideias e necessidades. Seguindo esse critério, o primeiro evento foi em março, logo após o carnaval e, por isso, o tema escolhido foi Ciência e Samba. No mês de abril, viriam as comemorações da Semana Santa e o debate teria como tema ciência e religião. Mas, devido a necessidades de projetos de pesquisa da equipe do DDC/UFMG, o tema passou a ser Ciência e Dengue.

Essas mudanças demonstram a abertura da equipe de concepção e produção do projeto de forma a buscar debates interessantes sob diversos pontos de vista.

O que chamou a atenção para o debate Ciência e Dengue foi o fato de que o tema selecionado pertence ao campo da Ciência, ao contrário do Samba e de outros que se sucederam.

A relação entre os dois campos acabou por potencializar não apenas os problemas da sociedade em lidar com a epidemia de Dengue, por exemplo, ou do governo e suas campanhas de prevenção, mas questões e conflitos dentro da própria esfera da Ciência.

\subsubsection{Perguntas tablet - entre a escrita e a oralidade e o "delay"}

O andamento dos debates do Projeto "Barômetro" foi delineado pelas 
perguntas enviadas pelo público participante através dos tablets. Embora os debates tenham começado a partir dos questionamentos colocados no texto, estudados e preparados previamente pela equipe da rádio, foram as perguntas elaboradas pelo público participante que direcionaram os assuntos colocados em discussão.

As perguntas tablets seguiam sempre o mesmo caminho - das palavras do campo semântico na esfera, ao teclado virtual, até a projeção pública das perguntas. Esse era, pode-se dizer, o percurso estético disponível para todos os presentes. Mas houve outro percurso, que pode ser chamado de percurso técnico, que correspondeu à formatação do banco de dados da pesquisa.

Cada vez que uma pergunta era enviada para a projeção, dava-se início à formação do banco de dados do software. O banco era alimentado pelas perguntas que se organizavam apenas pela ordem de envio. O tempo do envio não foi registrado, apenas a numeração da ordem com que chegavam ao software. Essa foi uma das adaptações que foram realizadas posteriormente para melhorar o processo de captação e tratamento de dados para futuras pesquisas.

A numeração do banco de dados não significou que as perguntas vindas a público foram feitas de acordo com essa ordem. Dessa forma, é necessário considerar o tempo, durante a transmissão, entre o envio da pergunta na projeção, a possibilidade dessa pergunta ser escolhida pelos assistentes da repórter tablet e ser transmitida à mesma para, finalmente, vir a público no debate. Para esse tempo, ou seja, o conjunto desses atos, pôde-se considerar que houve um "delay".

O "delay" foi aqui caracterizado por duas referências: o tempo da interação no qual o assunto proposto pela pergunta surgiu no debate e seu número correspondente no banco de dados. Apenas para relembrar, os tablets ficaram disponíveis para o público participante durante toda a transmissão do evento.

\subsubsection{Palavras da noite - campos semânticos Ciência e Dengue}

Palavras disponíveis nos tablets para o debate Ciência e Dengue:

CIÊNCIA: inovação, tecnologia, pesquisa, progresso, especialistas, cientistas, desenvolvimento, avanço, futuro, desconhecido, descoberta, domínio, laboratório, universidade, academia, estudo, método, conhecimento, informação, racional, empírico, verdade, natureza, realidade, cura, prática, saber, sabedoria, filosofia, experiência, cobaia, vida, hipótese, tese, inteligência, artificial, simulação, simulador, cérebro, ética, cientificamente testado, cientificamente aprovado, ficção científica 
DENGUE: SUS, dengue, casos, hemorrágica, óbitos, doença, epidemia, início, cama, molho, mito, caseiro, sorotipos, sudeste, sul, Brasil, década, enfermidade, febre, homem, infecção, milhões, pacientes, países, período, primatas, sorotipo, vírus, amarela, arbovírus, repelente, crianças, dengue-1, dengue-2, dengue-3, dengue-4, distribuição, endemia, gênero, humanos, imunidade, mortalidade, posto de saúde, ocasião, pessoas, população, relatado, rico, pobre, saúde, sintomas, temporária, tipos, tropical, vertebrado, 


\section{TEMAS E SUBTEMAS}

Nesse cenário acima descrito, as interações aconteceram. Em meio à organização, produção, negociação, movimentação, particularidades e nuances de um Café Científico com formato de um programa de rádio, comunidade científica, sociedade civil e suas respectivas representatividades se encontraram para debater sobre um tema polêmico e atual. $O$ processo de estabelecimento de temas e subtemas extraído das transcrições das interações discursivas dos debatedores do "Barômetro" Ciência e Dengue não poderia prosseguir dissociado desse cenário.

Os temas e subtemas propostos e a categorização das "imagens da ciência" no discurso dos falantes se constituíram por meio de um processo interpretativo desenvolvido com objetivo de testar a hipótese da pesquisa. A riqueza do material transcrito permite outras possibilidades interpretativas que não se restringem às aqui relacionadas.

Os temas foram apresentados de acordo com os seguintes demarcadores:

- Tempo da interação;

- Momento do script;

- Caracterização da resposta;

- Categorização das "imagens da ciência" no discurso dos falantes;

- Caracterização do ambiente multimodal;

- Pergunta tablet relacionada.

A seleção dos trechos da interação seguiu o critério de "desempacotamento" (BOSSLER, 2004). A partir daí, deu-se início a um processo de seleção de trechos considerados mais interessantes e pertinentes, caracterizados como desmembramentos temáticos, para a análise que se pretendeu construir.

\subsection{Conceito de tema nesta pesquisa}

As práticas de delimitação de temas e subtemas segundo os autores citados nas reflexões sobre Análise Temática possibilitaram o processo de construção do conceito de tema, do que nesta pesquisa foi considerado como tema e como subtema.

Alguns pontos foram colocados em evidência para esse processo. Em primeiro lugar, veio o cuidado com o contexto das interações com atenção especial para suas particularidades. Em segundo, o foco foi a emergência das ideias para 
identificar padrões de comportamento e experiências dos atores das interações relacionadas com a temática abordada. Os temas começaram a ser definidos e a partir deles decorreram os subtemas.

Ao ter como ponto de partida a definição dos temas como unidades que derivam dos padrões e que reúnem fragmentos, ideias ou experiências e que, ao se reunirem aos subtemas formam a compreensão do quadro das experiências coletivas, veio o terceiro ponto. Dessa maneira, as perguntas públicas e oralizadas pela equipe de repórteres da rádio e suas respectivas respostas se tornaram os binômios Tema e Subtema nesta pesquisa.

O conjunto de Temas e Subtemas levantado possibilitou não somente a análise pormenorizada das interações, como a verificação inicial da hipótese de pesquisa.

\subsection{Nomenclaturas}

- Médico - debatedor representante da comunidade científica;

- Dona de casa - debatedor representante da sociedade civil;

- Diarista - debatedor representante da sociedade civil;

- Músico - músico que se apresentou na noite do debate Ciência e Dengue;

- Público participante - pessoas presentes na noite do debate que fizeram perguntas pelo microfone;

- Repórter apresentadora - estudante do curso de Comunicação Social da UFMG que fez a condução do programa;

- Repórter tablet - estudante do curso de Comunicação Social da UFMG que fez a mediação entre público, perguntas enviadas pelos tablets e debatedores.

\subsection{Número total de registros no banco de dados}

76 - Entre: testes para aprender a manusear o tablet/ combinações de palavras sem registro de perguntas ou comentários/ combinações de palavras com registros aleatórios/espaços em branco.

\subsubsection{Tema 1}

Tempo da interação Tema: [09:32]-[09:39] 
Tempo da interação Subtema: [09:41]-[12:31]

\section{Momento do script:}

Este momento correspondeu ao primeiro bloco do debate logo após a abertura do programa, a apresentação do tema da noite, a apresentação dos debatedores e a execução da primeira música. Durante esse tempo, o público participante foi se familiarizando com os tablets e, ao mesmo tempo, dando início ao procedimento de envio de perguntas para a projeção.

\section{Caracterização da resposta:}

Resposta do médico a respeito das armas da ciência contra a dengue (pergunta que se referiu ao texto da campanha do governo de Minas Gerais para o ano de 2011 para o combate à dengue) e foi sua primeira participação no debate ("desempacotamento").

\section{Caracterização das imagens da ciência:}

Tema 1: Metodologia científica

Subtema 1.1: Dificuldades da ciência

Subtema 1.2: Dificuldades da ciência (dentro do campo científico)

Subtema 1.3: Dificuldades da ciência (fora do campo científico)

Subtema 1.4: Papel do cientista/ Linguagem da ciência/ Pesquisa científica

Subtema 1.5: Comunicação pública da ciência (estratégias de comunicação)

\section{Quadro 11 - Tema 1}

\section{Tema 1:}

Ciência e Dengue: armas da ciência contra a dengue/agora que a dengue é uma guerra

Subtema 1.1: "guerra contra a dengue faz parte já da dificuldade que temos em lidar com dengue"

Subtema 1.2: "do ponto de vista Subtema 1.3: "e mesmo da população" científico"

Subtema 1.4: a abordagem do cientista Subtema 1.5: não há estudos para os temas dengue para qualquer demonstrando que esta estratégia de tema é um pouco mais crítica que a lidar com dengue é útil/sim ou não abordagem das pessoas 
(continuação)

\section{Tema 1:}

Ciência e Dengue: armas da ciência contra a dengue/agora que a dengue é uma guerra

- porque ele tem que questionar e - a parte que ele se dedica chega questionar ou não a utilidade de determinada atitude

- ele se dedica mais à área da pesquisa, de estudo

- sua área não é necessariamente essa área de combate/ e de divulgação científica

- de divulgação até que é/não é? ... de comunicação com o público

- porque a nossa linguagem é muito diferente

- a linguagem nossa é muito difícil

- tentar talvez/ decodificar isto um pouco

- tentar informar

- tentar sanar algumas dúvidas

- embora muita coisa tenha sido feita em dengue, ainda não é suficiente

Fonte: Elaborado pela autora.

\subsubsection{Tema 2}

Tempo da interação Tema: [14:13]-[14:19]/ [20:28]-[20:44]

Tempo da interação Subtema 2.1 (dona de casa): [14:20]-[14:58]

Tempo da interação Subtema 2.2 (diarista): [20:44]-[21:56]

\section{Momento do script:}

Este momento correspondeu ao primeiro bloco do debate, após significativas participações do médico, foram as primeiras participações da dona de casa e da diarista no debate ("desempacotamento").

\section{Caracterização da resposta:}

Respostas/perguntas da dona de casa e da diarista a respeito de casos de dengue na família e nas proximidades de suas moradias.

Categorização das "imagens da ciência":

Tema 2: Epidemia da doença

Subtema 2.1: Metodologia científica (diagnóstico da dengue)

Subtema 2.2: Metodologia científica (diagnóstico da dengue) 
Quadro 12 - Tema 2

\section{Tema 2:}

Casos de dengue na família/ dona de casa: uma neta/duas cunhadas/um filho e uma nora/ e o caso mais sério/ foi do neto

Casos de dengue na família/ diarista: o filho/ o irmão/ e ela própria

Subtema 2.1: eu poderia até perguntar para ele se tem casos de pessoas/ de acordo com a imunidade da pessoa/ se dengue é mais grave ou não

Subtema 2.2: eu queria perguntar o porquê de que/ quando a gente vai no posto de saúde/ qualquer um que tenha dengue/ você demora sete dias para fazer o exame - a diarista contou o caso do filho da vizinha que morreu há cerca de três meses de dengue hemorrágica: ele teve dengue hemorrágica/ ele foi descobrir só na hora que morreu/ quando você vai ao posto/ se tem febre alta/está com vômito/ está com calafrios/ você está com dengue[...] aí eles falam/ daí a sete dias você volta/[...]aí/deu sete dias/ você faz o exame/não constou que é dengue/[...]/mas se for dengue você demora sete dias/[...]/então/o menino morreu porque não fizeram o exame antes/porque não tentaram descobrir antes?

Fonte: Elaborado pela autora.

\subsubsection{Tema 3}

Tempo da interação Tema: [20:44]-[21:56]

Tempo da interação Subtema: [22:00]-[22:33]

\section{Momento do script:}

Este momento correspondeu ao primeiro bloco do debate, logo após a primeira participação da diarista no programa.

\section{Caracterização da resposta:}

Resposta do médico em relação ao caso relatado pela diarista (filho da vizinha, uma criança, que faleceu vítima de dengue hemorrágica).

\section{Categorização das "imagens da ciência":}

Tema 3/ Subtema 3.1: Metodologia científica (diagnóstico da dengue)

\section{Quadro 13 - Tema 3}

\begin{tabular}{|l|}
\multicolumn{1}{c|}{$\begin{array}{c}\text { Tema 3: } \\
\text { O diagnóstico }\end{array}$} \\
\hline - o que você mede não é o vírus da dengue \\
- você mede a resposta do indivíduo ao vírus \\
- e o que você mede demora sete dias \\
- isso não significa que o diagnóstico clínico não seja de dengue \\
- então se alguém chega e está com febre/ e está tendo uma epidemia de dengue/ \\
você faz o diagnóstico clínico de dengue/ só vem sete dias depois
\end{tabular}

Fonte: Elaborado pela autora. 


\subsubsection{Tema 4}

Tempo da interação Tema (diarista): [22:38]-[22:46]

Tempo da interação Subtema (médico): [22:50]-[23:57]

\section{Momento do script:}

Este momento correspondeu ao primeiro bloco do debate e se relacionou ainda à primeira participação da diarista no programa.

\section{Caracterização da resposta:}

Resposta do médico à pergunta feita pela diarista.

\section{Categorização das "imagens da ciência”:}

Tema 4: Metodologia científica (diagnóstico da dengue)

Subtema 4.1: Altos custos da inovação na pesquisa científica/ Tecnologia importada/ Importação de tecnologia/ Cientificamente confiável/ Confiabilidade da ciência Subtema 4.2/ 4.2.1: Metodologia científica (tratamento da dengue)

\section{Quadro 14 - Tema 4}

\begin{tabular}{|c|}
\hline $\begin{array}{c}\text { Tema 4: } \\
\text { Não há um jeito mais fácil de a pessoa descobrir? (Diagnóstico) }\end{array}$ \\
\hline $\begin{array}{l}\text { Subtema 4.1: } \\
\text { - tem/ é novo/ está sendo testado } \\
\text { - e tem uma dificuldade } \\
\text { - a questão do custo } \\
\text { - você colocar um novo exame no sistema de saúde público tem um custo } \\
\text { - às vezes essa tecnologia é importada/ o custo passa a ser proibitivo } \\
\text { - você não tem como ter no sistema de saúde público } \\
\text { - já tem dois anos/ você tem métodos de fazer o diagnóstico mais rápido/ mas o } \\
\text { diagnóstico não é } 100 \% \text { confiável } \\
\text { - do ponto de vista clínico qualquer paciente gravemente enfermo vai ser tratado } \\
\text { da mesma forma }\end{array}$ \\
\hline Subtema 4.2: e dengue não tem tratamento específico \\
\hline $\begin{array}{l}\text { Subtema } 4.2 .1 \\
\text { - } \text { todo mundo acha ruim, mas vai ser tomar água/ hidratar/ tomar Tylenol } \\
\text { - não tem o que fazer/ não tem antibiótico } \\
\text { - não está com jeito que vai ter por uns bons anos }\end{array}$ \\
\hline
\end{tabular}

Fonte: Elaborado pela autora.

\subsubsection{Tema 5}

Tempo da interação Subtemas (diarista): [24:01]-[24:15]

Tempo da interação Subtemas (músico): [24:30]-[25:09] 


\section{Momento do script:}

Este momento correspondeu ao primeiro bloco do debate e ainda se relacionou à primeira participação da diarista no debate e à intervenção do músico em seu questionamento para o médico.

\section{Caracterização da resposta/ intervenção:}

Resposta da diarista em relação à pergunta que ela fez ao médico e a intervenção do músico no debate.

\section{Categorização das "imagens da ciência":}

Tema 5: Metodologia científica (diagnóstico da dengue)

Subtema 5.1.1: Metodologia científica

Subtema 5.2.1: Automedicação/ Tempo da ciência x Tempo da sociedade/ (Autoridade da ciência)

Quadro 15 - Tema 5

\begin{tabular}{|c|c|}
\hline \multicolumn{2}{|c|}{$\begin{array}{l}\text { Tema 5: } \\
\text { Entendimento/ comunicação (diagnóstico/tempo/ automedicação) }\end{array}$} \\
\hline $\begin{array}{l}\text { Subtema 5.1:Me desculpe/ o senhor não } \\
\text { respondeu a minha pergunta }\end{array}$ & $\begin{array}{l}\text { Subtema 5.2: } 0 \text { doutor }[\ldots] \text { meio que } \\
\text { respondeu sim }\end{array}$ \\
\hline $\begin{array}{l}\text { Subtema 5.1.1: } \\
\text { - demora muito/ e muitas das vezes a } \\
\text { pessoa está com uma doença grave/ e } \\
\text { é tratado como se estivesse com } \\
\text { dengue }\end{array}$ & $\begin{array}{l}\text { Subtema 5.2.1: } \\
\text { - a gente tem muito daquela coisa de se } \\
\text { automedicar } \\
\text { - sete dias para quem tem os sintomas/ } \\
\text { é uma coisa que demora muito } \\
\text { - eles dizem que a Aspirina é algo que } \\
\text { vai contra a cura }\end{array}$ \\
\hline
\end{tabular}

Fonte: Elaborado pela autora.

\subsubsection{Tema 6}

Tempo da interação Tema/ Subtemas: [25:10]-[27:22]

\section{Momento do script:}

Este momento correspondeu ao primeiro bloco do debate e retornou à questão dos passos necessários para o diagnóstico da Dengue.

\section{Caracterização da resposta:}

Resposta do médico em relação aos questionamentos da diarista e da intervenção do músico sobre a explicação dada pelo médico dos passos tomados para o diagnóstico da doença. Para a diarista, o médico não respondeu a sua pergunta e para o músico ele respondeu pela metade ("meio que respondeu sim"). 


\section{Categorização das "imagens da ciência":}

Tema 6: Metodologia científica (diagnóstico da dengue/ discurso da prática escolar)

Subtema 6.1: Metodologia científica (diagnóstico da dengue)

Subtema 6.2: Entendimento público da ciência (Sob o olhar do cientista - Saberes populares/ Automedicação)

Quadro 16 - Tema 6

\begin{tabular}{|c|c|}
\hline \multicolumn{2}{|c|}{$\begin{array}{c}\text { Tema 6: } \\
\text { Então/ voltarei um pouquinho/ o diagnóstico de dengue tem que estar em um } \\
\text { contexto/ }\end{array}$} \\
\hline $\begin{array}{l}\text { Subtema 6.1: "Diagnóstico" } \\
\text { - ele é de exclusão até você confirmar } \\
\text { - então/.../ é muito diferente de outras } \\
\text { doenças } \\
\text { - existem erros de diagnósticos } \\
\text { - existem casos que são muito } \\
\text { difíceis de diagnosticar } \\
\text { - existem casos que são muito graves } \\
\text { e que você não tem oportunidade de } \\
\text { [?] terapêutico } \\
\text { - então/ como em qualquer doença// } \\
\text { ninguém deve se automedicar/ evita- } \\
\text { se remédios que contenham aspirina } \\
\text { - e para o clínico/ após um exame bem } \\
\text { feito/ isso não é fato }\end{array}$ & $\begin{array}{l}\text { Subtema 6.2: "Pessoas leigas" } \\
\text { - para um leigo/ às vezes/ dengue se } \\
\text { parece com tudo/ mas é muito } \\
\text { diferente } \\
\text { - porque a aspirina faz com que as } \\
\text { pessoas leigas chamam de ralear o } \\
\text { sangue } \\
\text { - mas não se deve automedicar nunca/ } \\
\text { porque para o leigo as doenças são } \\
\text { semelhantes/ } \\
\text { - (automedicação em dengue é grave) } \\
\text { - (a automedicação deve ser proibida) }\end{array}$ \\
\hline
\end{tabular}

Fonte: Elaborado pela autora.

\subsubsection{Tema 7}

Tempo da interação Tema: [17:53]-[17:58]

Tempo da interação Subtema: [18:06]-[19:12]

\section{Momento do script:}

Este momento correspondeu ao primeiro bloco do debate e apresentou não somente a receita do repelente no discurso da dona de casa, como o próprio repelente que circulou entre os presentes para que pudessem manuseá-lo e cheirá-lo.

\section{Caracterização da resposta:}

Resposta da dona de casa sobre a receita e o repelente natural contra o mosquito da dengue que a debatedora levou para o programa.

\section{Categorização das "imagens da ciência":}

Tema 7: Saberes populares/ 
Subtema 7.1: Comunicação pública da ciência - Teste respaldado pela academia ("Cientificamente testado")/ Baixo custo/ Saberes populares

Quadro 17 - Tema 7

\section{Tema 7:}

E a senhora tem uma receita de repelente natural, ...

Subtema 7.1:

- vi no programa da ... (programa de TV de grande projeção nacional)

- ele foi testado na hora com um médico e uma outra pessoa da faculdade lá do Rio de Janeiro

- além de ser muito fácil

- é um cheirinho muito gostoso e barato

Fonte: Elaborado pela autora.

\subsubsection{Tema 8}

Tempo da interação Tema/ Subtemas: [19:20]-[20:28]

\section{Momento do script:}

Este momento correspondeu ao primeiro bloco do debate e, após a divulgação da receita do repelente natural e do manuseio do mesmo pelo público, o médico pediu para falar.

\section{Caracterização da resposta:}

Manifestação do médico diante da receita de repelente natural contra o mosquito da Dengue veiculada em um programa de televisão de projeção nacional.

\section{Categorização das "imagens da ciência":}

Tema 8: Saberes populares

Subtema 8.1: Validade da pesquisa científica/ Metodologia científica/ Confiabilidade da ciência/ Ceticismo em relação ao popular e barato/ Ciência e instâncias governamentais/ Ciência e sociedade/ Riscos em relação ao que não é produto da ciência ou cientificamente testado/

Subtema 8.2: Responsabilidade da ciência - A quem pertencem os problemas da ciência? 
Quadro 18 - Tema 8

\section{Tema 8:}

Manifestação do médico em relação à receita do repelente natural

Subtema 8.1:

- eu tenho muito medo de receitas populares

- foi feito (no programa de TV) francamente não é válido

- não foi feito com número suficiente de pessoas

- medo ... que as pessoas passem a confiar em alguma coisa que não foi testada de forma adequada

- o fato de ser um produto/ entre aspas/ natural/ não significa que ele não tenha riscos

- olhar com um certo ceticismo estes produtos naturais e muito baratos

- transportar a sua segurança para um produto que/ às vezes/ não é bom

Subtema 8.2: o problema da dengue

- é de todo mundo

- mas também é da prefeitura/

- é do estado que é um pouco que eu não vejo nas campanhas

- é um problema das pessoas

- mas não é meu/é do estado

- mas (retorna ao repelente)/ não estou dizendo que não funcione/ mas tome cuidado

Fonte: Elaborado pela autora.

\subsubsection{Tema 9}

Tempo da interação Tema: [29:53]-[30:05]

Tempo da interação Subtema (diarista): [30:06]-[31:03]

Tempo da interação Subtema (dona de casa): [31:09]-[32:05]

Tempo da interação Subtema (médico): [32:12]-[33:42]

\section{Momento do script:}

Este momento correspondeu ao segundo bloco do debate e ao início das perguntas feitas pelos tablets e selecionadas pelos assistentes da "repórter tablete" e o Tema 9 foi retirado da segunda pergunta tablet.

Caracterização das respostas:

Respostas da diarista, da dona de casa e do médico, respectivamente, em relação aos cuidados que cada um toma em casa para a erradicação da dengue.

Categorização das "imagens da ciência":

Tema 9: Entendimento púbico da ciência

Subtema 9.1: Ensino de ciências (a escola)

Subtema 9.2: Aplicação da ciência (remédio) / Entendimento público da ciência 
(mobilização da população)

Subtema 9.3: $O$ discurso da ciência $\mathrm{x}$ o discurso da prática

\section{Pergunta tablet:}

Número no banco de dados: 18/76

Tempo que veio a público na interação: [29:53]-[30:05]

Registro original: sorotipos/ universidade - dengue erradicada com cuidados em casa?

Pergunta oralizada: dengue pode ser erradicada com cuidados em casa?/ certamente/ é uma maneira de contribuir para erradicação da dengue são os cuidados em casa/ eu queria saber então da (diarista)/ quais são os cuidados na sua casa?

Desdobramentos:

- Senhora (dona de casa)/ quais são os cuidados que a senhora toma dentro de casa?

- Professor (médico)/ e o que você faz para combater a dengue?

Quadro 19 - Tema 9

\section{Tema 9:}

Dengue pode ser erradicada com cuidados em casa?

Subtema 9.1: Diarista

- lá em casa a gente coloca areia nos pratinhos/ não deixa a caixa d'água destampada/.../ o ralinho do banheiro sempre tampado

- M,e a gente vigia a rua/ ... /se a gente vê [...] uma canequinha/ a gente vira

- tentamos cuidar do quintal da gente/ [...] do quintal do vizinho também

- hoje em dia é bom que nas escolas ensinam isto/ .../ muitas das crianças já aprendem na escola e faz dentro de casa/ então na escola/ eles ajudam bastante/ entendeu?

- as pessoas estão tendo consciência de limpar seus quintais

Subtema 9.2: Dona de casa

- eu troquei a caixa d'água

- sempre subo lá em cima da escada para olhar as calhas/ .../ os pratos/ eu retirei todos

- quando a gente vai lá/ eu peço que me jogue aquele remédio verde em todos os ralos do jardim/

- e ainda/ eu vou à rua/ .../ os meninos que iam lá tirar estas graminhas do paralelepípedo/ eu mesma fazia isto/ para não juntar lixo e não juntar água

- tem uma sorveteria bem na esquina/ .../ olhe como é a falta de consideração das pessoas quanto a dengue/ .../ eles vão enfiando todos os copos de sorvete vazios/ na árvore com a boca para cima 
(continuação)

Tema 9:

Dengue pode ser erradicada com cuidados em casa?

Subtema 9.3: Médico

- eu moro em apartamento/ .../ o risco é um pouco menor

- a dificuldade da dengue é que o mosquito voa/ .../ e o alcance dele é de centenas de metros/

- eu acho que/ em casa/ estes cuidados com água parada/ com pratinhos/ alguns tipos de plantas/ o ralo do banheiro/ nas casas que tem calha/ isto é responsável/ pelos estudos da prefeitura de Belo Horizonte/ por cerca de $70 \%$ dos casos de dengue

- certamente/ o individual não tem sido suficiente/ porque as pessoas/ na hora do discurso/ dizem que tomam o cuidado necessário/mas [a dengue] não está diminuindo/ existe uma flutuação ...

- as pessoas/ às vezes/não percebem

- tem epidemias de dengue a cada quatro/três a seis anos/ a dengue 4 veio para o Brasil agora/ então/ é possível que haja uma epidemia no ano que vem ou no outro

Fonte: Elaborado pela autora.

\subsubsection{Tema 10}

\section{Parte A}

Tempo da interação Tema: [34:20]-[34:28]

Tempo da interação Subtema (médico): [34:29]-[34:56]

Tempo da interação Subtema (público participante 21): [35:09]-[35:51]

Tempo da interação Subtema (médico): [35:36]-[36:59]

Tempo da interação Subtema (público participante): [37:00]-[37:09]

Tempo da interação Subtema (médico): [37:13]-[37:36]

\section{Momento do script:}

Este momento correspondeu ao segundo bloco do debate e se referiu à terceira pergunta tablet. Este bloco foi marcado pela primeira participação do público por meio do microfone.

\section{Caracterização das respostas:}

Resposta do médico em relação aos mitos relacionados à Dengue e intervenções de uma participante do público a respeito de um "chá milagroso" contra a dengue. $\mathrm{Na}$ resposta do médico, encontrou-se referência à projeção da esfera e das perguntas durante o programa e foi um registro do gestual do médico ao visualizar a projeção e participar do debate ao mesmo tempo.

A intervenção da doméstica e sua interação com o médico também foi marcada por 
outro registro gestual. Insatisfeita com a posição cética do médico a respeito do chá que a curou, ela se virou para as pessoas sentadas próximas e ela, comentou e gesticulou ao mesmo tempo: "esse médico não sabe de nada".

\section{Categorização das "imagens da ciência":}

Tema 10 A: Mitos

Subtema 10.1 A: Entendimento público da ciência/ Mitos

Subtema 10.2 A: Saberes populares

Subtema 10.3 A: Pesquisa científica/ Confiabilidade da ciência

Subtema 10.4 A: Saberes populares

Subtema 10.5 A: Saberes populares/ Mitos

\section{Caracterização do ambiente multimodal:}

Registro em áudio de estímulo visual (ver no quadro abaixo, frase em itálico).

\section{Pergunta tablet:}

Número no banco de dados: 23/76

Tempo que veio a público na interação: [34:29]-[34:56]

Registro original: dengue-3/ mito - qual o mais perigoso mito da dengue?

Pergunta oralizada: além do fumacê/ existe algum mito relacionado à dengue?/ ou qual o maior/mais perigoso/ relacionado à dengue?

$$
\text { Quadro } 20 \text { - Tema } 10 \text { A }
$$

\section{Tema 10 A:}

além do fumacê/ existe algum mito relacionado a dengue? Ou qual o maior/ mais perigoso relacionado a dengue?

Subtema 10.1 A: Médico

- eu vi esta pergunta passando e fiquei pensando/ eu queria ouvir alguns mitos/ porque [...] tem muito de verdade no que as pessoas dizem/ eu acho que existem alguns exageros

- mas o do fumacê é fantástico

Subtema 10.2 A: Público participante 21(doméstica)

- tive uma dengue horrível/ dor no corpo/ eu achei que iria morrer/ então/ pensei bem/ quer saber de uma coisa?/ em mim você não vai ficar

- tomei um chá fortíssimo/ com limão/ cebola/ alho e mel/ com três dias/ eu estava ótima

- com três dias acabou/ e teve vários casos de dengue perto da minha casa/ e em mim não pegou mais não/ estou com 55 anos/ mas estou aí/ tranquila 
(continuação)

Tema 10 A:

além do fumacê/ existe algum mito relacionado a dengue? Ou qual o maior/mais perigoso relacionado a dengue?

Subtema 10.3 A: Médico

- não vou dizer que o chá é um mito

- em estudos que fizeram com doadores de sangue/ .../ tem até $90 \%$ de pessoas que foram infectadas pela dengue/ e dessas/ $\mathbf{9 0 \%}$ não sabiam que tinham sido infectadas

- a maioria das pessoas não adoece quando é infectada/ é uma minoria

- direi o seguinte/ a senhora melhorou com/ sem e apesar dele

Subtema 10.4 A: Público participante 21 (doméstica)

- mas acontece que eu fui persistente/ e eu tinha certeza de que iria sarar

Subtema 10.5 A: Médico

- o uso do chá é uma manifestação forte da cultura brasileira

- se não fal $\mathrm{mal} / \mathrm{faz}$ bem

- se você acha que o chá te curou/.../ se ele não faz mal/ faz bem

- do ponto de vista médico/ ele é mito/ exatamente [risos]/ neste sentido

Fonte: Elaborado pela autora.

\section{Parte B}

Tempo da interação Tema: [37:37]-[37:41]

Tempo da interação Subtema (dona de casa): [37:45]-[38:03]

Tempo da interação Subtema (médico): [38:04]-[38:42]

\section{Momento do script:}

Este momento correspondeu ao segundo bloco do debate e se referiu ainda à pergunta tablet sobre dengue e mitos. O músico fez sua segunda intervenção/ participação no debate e levantou outra questão relacionada aos mitos e saberes populares.

\section{Caracterização da resposta:}

Resposta do médico sobre o comentário feito pela dona de casa com a "repórter tablete" sobre uma história de comer inhame. A dona de casa levou o comentário a público e acabou por provocar novamente a participação do músico.

Categorização das imagens da ciência:

Tema 10 B: Mitos/ Saberes populares

Subtema 10.1 B: Saberes populares

Subtema 10.2 B: Comunicação pública da ciência (Metodologia científica/ Eficácia da 
ciência/ Confiabilidade da ciência)

Pergunta tablet: Desdobramento do tema anterior.

Tempo que veio a público na interação: [37:37]-[37:41]

Pergunta oralizada: Professor/ um outro mito/ eu estava conversando antes com a dona (dona de casa) e ela falou uma história de comer inhame.

Quadro 21 - Tema 10 B

\section{Tema $10 \mathrm{~B}$ :}

professor/ um outro mito/ eu estava conversando (com a dona de casa) e ela falou uma história de comer inhame

Subtema 10.1 B: Dona de casa

- eu também ouvi falar/ como diz a gíria popular/ que se a pessoa comesse bastante [inhame]

- isto também diminuiria/ ou então/ você não iria pegar a dengue

Subtema 10.2 B: Médico

- demonstrar cientificamente que a dengue é diminuída pelo inhame/ não tem como

- então/vamos fazer o seguinte/ o inhame faz bem

- eu acho que/ como boa norma/ [...] a alimentação tem de ser ampla

- deve-se evitar tomar remédios à toa/ porque remédio não faz bem

- não há necessidade de tomar vitaminas/ como é vendido na televisão/ vitaminas são desnecessárias

Fonte: Elaborado pela autora.

\section{Parte C}

Tempo da interação Tema (músico): [39:01]-[39:21]

Tempo da interação Subtema (médico): [39:24]-[39:43]

\section{Momento do script:}

Este momento correspondeu ao segundo bloco do debate e se referiu à intervenção do músico na discussão sobre se o inhame faz bem para curar a dengue ou se faz bem para a pele (registro praticamente inaudível dessa parte).

\section{Caracterização da resposta:}

Intervenção e participação do músico sobre os benefícios do inhame. Ele acrescentou outro elemento neste ponto do debate - o "psicológico".

\section{Caracterização das imagens da ciência:}

Tema 10 C: Saberes populares

Subtema 10.1 C: Saberes populares

Subtema 10.2 C: Entendimento público da ciência 
Quadro 22 - Tema 10 C

\begin{tabular}{|l|}
\hline \multicolumn{1}{|c|}{ Tema 10 C: } \\
\hline Subsicológico" \\
- eu acho que a questão também do psicológico ajuda muito/ também na cura/ \\
porque era o inhame/ era o chá de alho \\
- mas acho que com uma boa caminhada ajuda no bom condicionamento físico/ \\
eu acho que a cura... \\
- eu acho que o psicológico também vai contra a doença \\
\hline Subtema 10.2 C: Médico \\
- então/ o psicológico não é só a cura/ \\
- mas é também a percepção/ é forma como se lida com as coisas \\
- se você está bem/ é mais fácil/ a vida é mais tranquila
\end{tabular}

Fonte: Elaborado pela autora.

\subsubsection{Tema 11}

Tempo da interação Tema (público participante 22 - professora): [40:12]-[40:34] Tempo da interação Subtema (médico): [40:34]-[41:54]

\section{Momento do script:}

Este momento correspondeu ao final do segundo bloco do debate e à segunda participação do público.

\section{Caracterização da resposta:}

Pergunta/ comentário vindo de uma professora a respeito da participação de crianças no combate à dengue e a percepção das mesmas em relação à gravidade das epidemias de dengue.

\section{Categorização das imagens da ciência:}

Tema 11: Ensino de ciências/ Entendimento público da ciência

Subtema 11.1: Comunicação pública da ciência (Pesquisa científica/ Tipos ou formas de comunicação pública da ciência)

Subtema 11.2: Pesquisa científica sobre Entendimento público da ciência/ Questões culturais e Comunicação pública da ciência

\section{Pergunta tablet relacionada:}

Número no banco de dados: 36/76

Tempo que veio a público na interação: [40:12]-[40:34]

Registro original: crianças/ doença - há muitas campanhas de prevenção que envolvem as crianças. Como elas realmente podem compreender a dimensão da dengue na nossa cidade? 
Pergunta oralizada: foi falado a respeito da participação de crianças no combate à dengue/ eu/ como professora/ percebo que muitas vezes esses trabalhos de prevenção acabam criando nas crianças um sentimento de pouca dimensão da gravidade dessa questão de saúde/ é realmente um problema social/ como vocês veem isso?

Desdobramentos:

- Perguntas feitas pela "repórter tablet" para uma criança presente no evento: você tem medo de dengue?/ (resposta)/ e você usa o repelente que a sua avó (a criança é neta da dona de casa) aprendeu no (programa de televisão)?/ (resposta)/ você usa algum outro repelente/ não usa?/ (resposta)/ mas é um que já compra na farmácia?/ (resposta)/ (nome da criança)/ e o que vocês aprendem sobre dengue na escola?/ tem campanha?/ (resposta)/ aprendem sobre transmissão/ sobre essa coisas assim?/ (resposta)

Quadro 23 - Tema 11

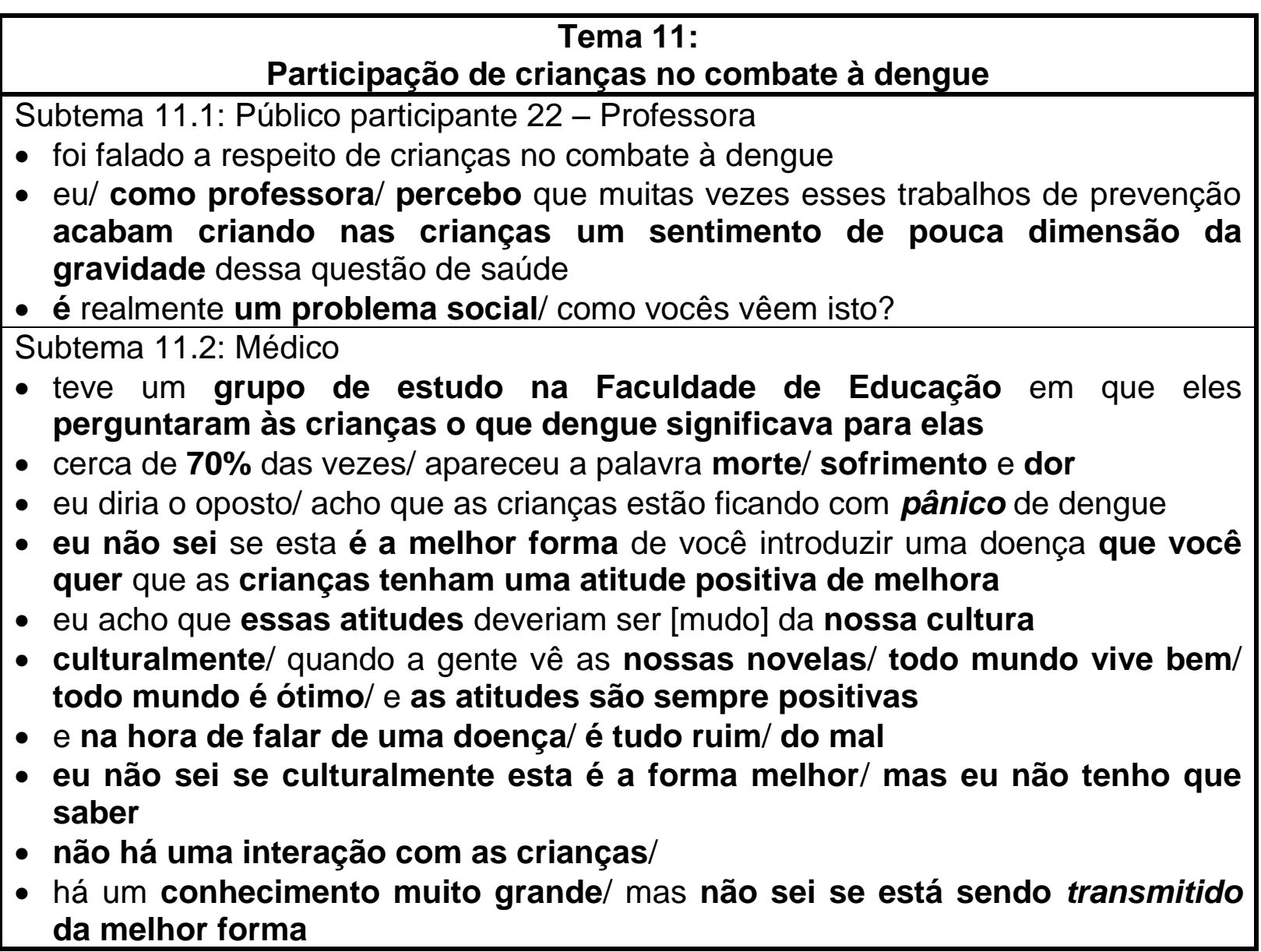

Fonte: Elaborado pela autora. 


\subsubsection{Tema 12}

Tempo da interação Tema: [58:30]-[58:35]

Tempo da interação Subtema (dona de casa): [58:36]-[59:22]

Tempo da interação Subtema (diarista): [59:23]-[01:00:12]

Tempo da interação Subtema (médico): [01:00:14]-[01:00:44]

Tempo da interação Subtema (diarista): [01:00:44]-[01:01:21]

\section{Momento do script:}

Este momento correspondeu ao terceiro e último bloco do debate e, após discussão sobre a questão debatida anteriormente, dengue e sentimentos das crianças, a repórter tablet entrou com a quarta pergunta tablet. Antes desse bloco, aconteceu a terceira apresentação musical.

\section{Caracterização da resposta:}

Respostas da dona de casa, da diarista e do médico sobre a associação entre dengue e pobreza.

\section{Categorização das imagens da ciência:}

Tema 12: Epidemia e Condições socioeconômicas e culturais

Subtema 12.1: Infraestrutura pública

Subtema 12.2: Infraestrutura pública

Subtema 12.3: Infraestrutura pública

Subtema 12.4: Infraestrutura pública

\section{Pergunta tablet:}

Número no banco de dados: 56/76

Tempo que veio a público na interação: [58:30]-[58:32]

Registro original: dengue-2/ pobre - dengue e pobreza podem ser associados?

Pergunta oralizada: dengue e pobreza podem ser associados?

Quadro 24 - Tema 12

\section{Tema 12:}

dengue e pobreza podem ser associados?

Subtema 12.1: Dona de casa

- eu acho que não é questão de ser associado

- não é questão de pobreza/ é questão do meio ambiente que as pessoas/ principalmente a Prefeitura .../ enquanto ela arruma milhões de vezes a praça da Liberdade/ o outro nem asfalto tem 
(continuação)

Tema 12:

dengue e pobreza podem ser associados?

Subtema 12.2: Diarista

- eu acho que muita das vezes o pobre fica mais preocupado com a [limpeza]/ [...]/ que a classe média/ não tem saneamento básico/ não tem nada

- mas o pobre limpa/ [...]/limpamos da maneira que a gente pode/

- muitas das vezes/ na casa do rico/tem a piscina/ ele não pensa em cobrir aquela piscina

- às vezes/ em um bairro de classe média/ tem mais dengue que em um bairro de classe pobre/

- [...] este povo pensa que dengue só ataca pobre/ mas não ataca [só] pobre/ ataca rico também!

Subtema 12.3: Médico

- absolutamente democrática/ [...]/ ela não escolhe o lugar

- então o acesso do serviço público às regiões mais pobres/às vezes/ é complicado

Subtema 12.4: Diarista

- tudo em um bairro em que a pessoa é mais humilde é menos favorecido/

- então/ lá/ cada um tem que cuidar de si/ e Deus para todos/

- lá a gente não tem esse negócio que ... igual ela falou comigo/ "você joga fumacê lá no seu bairro?"/

- o que eu vejo é o pessoal de seis em seis meses que passa lá/ joga um remedinho e pronto/

- a gente mesmo tem que se virar

Fonte: Elaborado pela autora.

\subsubsection{Tema 13}

Tempo da interação Tema: [01:01:30]-[01:01:59]

Tempo da interação Subtema (diarista): [01:02:00]-[01:03:05]

Tempo da interação Subtema (público participante): [01:03:20]-[01:03:26]

Tempo da interação Subtema (diarista): [01:03:26]-[01:03:29]

\section{Momento do script:}

Este momento correspondeu ao terceiro bloco do debate e retomou um trecho da resposta da diarista sobre os cuidados que ela toma em casa para prevenir a dengue, quando ela relatou a respeito do que seus filhos aprendem na escola em relação ao combate à dengue.

\section{Caracterização da resposta:}

Resposta da diarista a uma pergunta feita por alguém do público participante a respeito de projetos desenvolvidos na escola de seus filhos para evitar ou prevenir a dengue e sua mudança de atitude devido a isso. 
Categorização das imagens da ciência:

Tema 13: Ensino de ciências

Subtema 13.1: Ensino de ciências (Projetos na escola)/ Entendimento público da ciência (Conscientização de gerações futuras)

Subtema 13.2: Ensino de ciências (Mudança de hábito)

Subtema 13.3: Ensino de ciências (Mudança de hábito)

Quadro 25 - Tema 13

Tema 13:

seu filho/ ou sua filha/ [...]/ que tem um trabalho na escola dele/ a escola está trabalhando com projetos [mudo] mas para evitar ou para prevenir a dengue/ a senhora acha que a escola tem [mudo]

Subtema 13.1: Diarista

- na aula de ciências/ e as crianças/ um vez por mês/ saem limpando as ruas/ elas saem com os lixinhos/ elas vão com os professores de ciências

- é um trabalho [mudo] as crianças catam [mudo] casas dos vizinhos/ conscientizam

- são crianças de oito a nove anos que/ muitas das vezes/ vão na casa de cada vizinho/ que perguntam a eles se eles sabem como cuidar de seus terreiro/ que joga pneu velho/ que tira as latas do meio do terreiro/

- na mecânica/ porque muitas das vezes na oficina de mecânica tem os pneus que vão entulhando

- isto ajudou muito no meu bairro/

- eu acho que se em cada escola os professores conscientizassem as crianças que elas podem cuidar de seu terreiro e ensinar para seus vizinhos/ nós teríamos uma geração melhor/ uma geração de adultos mais conscientes

Subtema 13.2: Público participante

- A senhora já modificou a sua atitude em relação à dengue em função da intervenção da escola

Subtema 13.3: Diarista

- Já/ muitas das vezes

Fonte: Elaborado pela autora.

\subsubsection{Tema 14}

Tempo da interação Tema: [01:04:32]-[01:04:38]

Tempo da interação Subtema: [01:04:40]-[01:06:40]

\section{Momento do script:}

Este momento correspondeu ao terceiro bloco do debate e se referiu à quinta pergunta tablet. Novamente o médico mencionou a projeção da esfera semântica e das perguntas, fez comentários em relação às perguntas e demonstrou sua ansiedade diante dessa situação. 


\section{Caracterização da resposta:}

Resposta do médico em relação à possibilidade de cura da doença e de qual seria o prazo para isso.

\section{Categorização das imagens da ciência:}

Tema 14: Metodologia científica

Subtema 14.1: Metodologia científica (Relação Ciência x Governo/ Tempo da Ciência x Tempo da Sociedade)

\section{Caracterização do ambiente multimodal:}

Registro em áudio de estímulo visual (ver no quadro abaixo frase em itálico).

\section{Pergunta tablet:}

Número no banco de dados: 47/76

Tempo que veio a público na interação: [01:04:32]-[01:04:38]

Registro original: será possível uma cura da dengue independente do combate a larva ou ao mosquito? Em que prazo de tempo?

Pergunta oralizada: será possível uma cura dengue da dengue independente do combate à larva ou ao mosquito?

\section{Quadro 26 - Tema 14}

\section{Tema 14:}

será possível uma cura da dengue independentemente do combate à larva ou ao mosquito?/ e que prazo de tempo tem isso?

Subtema 14.1: Médico

- para quem está olhando para os tablets/ é muito legal ver as perguntas que estão surgindo/ é/ às vezes/ a falta de conhecimento/ quero dizer/ tem tanta coisa que é fácil de responder/ que dá uma ansiedade/

- qualquer doença/ quanto mais opções de controle você tem/melhor para você/ melhor as suas opções e a sua estratégia/

- hoje/ resta para a dengue apenas o controle de larvas/ ponto/ não tem tratamento/ não tem prevenção/ é individual

- então/ vacina contra a dengue é uma realidade ... acontecerá/

- mas o ministro da saúde falou no ano passado que em cinco anos isso aconteceria/ ele é louco/ eu como ministro não falaria isso nunca/

- porque ele vai errar/ não há previsão/ [muitos anos] talvez uma década/

- mais alguns anos/ pela própria natureza de uma nova vacina/ tratamentos individuais surgirão/ antivirais/ anti-inflamatórios

- vocês não vão conseguir tirar um número de mim de jeito nenhum/ tá?/ seria um chute qualquer número que eu dissesse/

- eu acho que as perspectivas são boas/ mas é um intervalo que para a maioria das pessoas é um intervalo longo/ mas que para as ciências é um intervalo bastante curto/ é uma visão diferente/

- é óbvio que todos querem uma cura para amanhã

Fonte: Elaborado pela autora. 


\subsubsection{Tema 15}

Tempo da interação Tema: [01:06:41]-[01:06:56]

Tempo da interação Subtema: [01:06:56]-[01:08:25]

\section{Momento do script:}

Este momento correspondeu ao terceiro bloco do debate quando a repórter tablet se referiu ao comentário feito pelo médico sobre as "perguntas fáceis" de responder, mas que trouxeram dúvidas tanto para ela quanto para as pessoas presentes no evento.

\section{Caracterização da resposta:}

Resposta do médico de uma pergunta enviada pela tablet sobre os tipos de dengue.

\section{Categorização das imagens da ciência:}

Tema 15: Linguagem científica/ Entendimento público da ciência

Subtema 15.1: Metodologia científica/ Relação Ciência x Governo/ Espaço de produção da ciência/ Validação da ciência

\section{Caracterização do ambiente multimodal:}

Registro em áudio de estímulo visual (ver no quadro abaixo frase em itálico).

\section{Perguntas tablet relacionadas:}

Número no banco de dados/Registro original:

32/76 - dengue-IV / pessoas - o que tem de mais grave a dengue-IV?

49/76 - descoberta/ inovação - professor o senhor acredita que um dia venceremos essa guerra? a dengue já está na sua versão IV e nós ainda não conseguimos educar a população nem pra versão II

55/76 - dengue-II / dengue-IV - mais espécies ainda devem surgir?

60/76 - dengue-III / pesquisa - qual a diferença entre dengue-III e dengue-IV?

65/76 - dengue- IV / método - tem dengue-IV em Minas

Tempo que veio a público na interação: [01:06:41]-[01:06:56]

Pergunta oralizada: professor/ o senhor disse que aparecem perguntas fáceis de resolver/ esta é uma dúvida minha e dúvida de quem está aqui também: quando aparece dengue-I/ dengue-II/ dengue-III/ dengue-IV... o que é isto? Qual e a diferença entre estes tipos ... podemos falar em tipo de dengue? 
Quadro 27 - Tema 15

\section{Tema 15:}

professor/ o senhor disse que aparecem perguntas fáceis de resolver/ esta é uma dúvida minha e dúvida de quem está aqui também: quando aparece dengue-I/ dengue-II/ dengue-III/ dengue-IV ... o que é isto? qual é a diferença entre estes tipos? ... podemos falar em tipos de dengue?

Subtema 15.1: Médico

- são sorotipos/

- seria como você pensar que fossem quatro doenças diferentes/ são quatro vírus/ tipos virais diferentes

- quero dizer/ podemos ter quatro crises de dengue em nossa vida/

- ao ter dengue-I/ você nunca mais vai ter dengue-I/ mas você poder a dengue-II/ dengue-III ou dengue-IV/

- então/ são quatro tipos de dengue diferentes para a maioria das pessoas terem a forma de ver/ tem dengue-IV em Minas/ tem/ não tem lógica/ em São Paulo/ no Rio/ em Goiás/ na Bahia/ e no estado de Minas o mosquito respeitou as fronteiras/

- só que para o Estado aceitar que tem dengue/ ele tem que cumprir algumas normas/

- e/ essas normas não são/ às vezes/ as normas que os cientistas usam/

- então/ em nosso laboratório/ já achamos dengue-IV/ e o secretário de saúde acha que não é suficiente ...

- é suficiente para publicar e tudo/ mas não é suficiente para o Estado/ porque as normas são diferentes

Fonte: Elaborado pela autora.

\subsubsection{Tema 16}

Tempo da interação Tema (dona de casa): [01:08:28]-[01:08:41]

Tempo da interação Subtema (médico): [01:08:42]-[01:10:46]

\section{Momento do script:}

Este momento correspondeu ao terceiro bloco do debate e se referiu a uma pergunta feita pela dona de casa ao médico.

Caracterização da resposta:

Resposta do médico a respeito do qual será a primeira informação do estudo que está sendo realizado sobre dengue que vai chegar para a população.

\section{Categorização das imagens da ciência:}

Tema 16: Pesquisa científica/ Comunicação pública da ciência/

Subtema 16.1: Confiabilidade da ciência/ Responsabilidade da ciência/ Validação da ciência/ Metodologia científica/ Tempo da ciência/ Investimento na ciência/ Custo da ciência 
Caracterização do ambiente multimodal:

Registro em áudio de estímulo visual (ver no quadro abaixo frase em itálico).

Quadro 28 - Tema 16

\section{Tema 16:}

Dona de casa

No estudo que vocês fazem/ o que acha que será a primeira coisa que vai chegar para a população?

Subtema 16.1: Médico

- então/ primeira coisa que eu gostaria [risos] que chegasse para a população ... por isso que eu tenho medo na hora de falar de repelente ...

- quando você fala em tratar um ser humano com um remédio/ com vacina/ a coisa mais importante que você tem que ter em mente chama-se segurança/

- você tem que ter cinco coisas/ as quatro primeiras são segurança e depois a eficácia/

- então/ para eu testar alguma coisa/ eu tenho que comprovar que é seguro muitas vezes/

- eu acho que existe uma chance razoável de nos próximos anos ... que é uma das primeira coisas que talvez chegue/ sejam remédios que diminuam a gravidade da doença/

- as vacinas devem chegar em um prazo de em torno de dez a vinte anos/ isto é rápido/

- teve uma pergunta que dizial "a humanidade deixou a dengue para trás?"/ certamente/ a dengue deixou de ser uma doença importante/ e ela retornou como uma doença importante nos últimos dez anos/

- crescimento de dengue é absurdo nos últimos anos/ é absurdo/ então/ a quantidade de dinheiro que existe para trabalhar e se pesquisar em dengue aumentou o interesse das pessoas/

- existe o interesse de algumas companhias farmacêuticas/nós vemos as companhias como seres do mal/ mas normalmente/ sem elas/ não tem como desenvolver novos medicamentos/

- a gente não tem capacidade/ não tem recursos para desenvolver por causa do custo da segurança/

- então/ o cenário é diferente/ então/ as coisas vão andar agora/ eu acho

Fonte: Elaborado pela autora.

\subsubsection{Tema 17}

Tempo da interação Tema: [01:14:07]-[01:14:09]

Tempo da interação Subtema: [01:14:11]-[01:16:26]

\section{Momento do script:}

Este momento correspondeu ao final do terceiro bloco do debate e ao encerramento das perguntas. Após a resposta do médico, houve uma apresentação musical e, 
pouco depois, a repórter apresentadora pronunciou o encerramento do debate. A transmissão em tempo real continuou por cerca de 30 minutos, somente com a apresentação dos músicos. Essa foi, portanto, a última participação do médico como debatedor do evento.

\section{Caracterização da resposta:}

Resposta do médico da última pergunta tablet escolhida pelos assistentes da "repórter tablet" sobre os estudos no Brasil em relação à dengue.

\section{Categorização das imagens da ciência:}

Tema 17: Pesquisa científica/

Subtema 17.1: Comunicação pública da ciência/ Entendimento público da ciência/ Ensino de ciências/Pesquisa científica/ Eficácia e falibilidade da ciência/ Inovação/ Custo da pesquisa científica/ Relevância de temas da ciência (dengue ser vista como importante) $x$ Contexto de produção da ciência

\section{Caracterização do ambiente multimodal:}

Registro em áudio de estímulo visual (ver no quadro abaixo frase em itálico)

\section{Pergunta tablet relacionada:}

Número no banco de dados: 54/76

Tempo que veio a público na interação: [01:14:07]-[01:14:09]

Registro original: Brasil/ estudo - como estão os estudos sobre a dengue no Brasil? Pergunta oralizada: como é que são os estudos no Brasil em relação à dengue? 
Quadro 29 - Tema 17

\section{Tema 17: \\ Médico}

Como é que são os estudos no Brasil em relação à dengue?

Subtema 17.1: Médico

- [...] é uma coisa que nós estamos tentando...

- é engraçado as pessoas não ouvirem isso através da mídia/

- isto é obviamente uma incompetência dos órgãos da universidade em dizer que muita coisa sendo feita/

- é muita coisa relativa porque a massa crítica no Brasil é pequena

- mas tem muita coisa sendo feita/ em todos os níveis/ desde a educação/

- de desenvolvimento de formas de conversar com as pessoas/

- de controle de larvas/ de desenvolvimento de novas tecnologias para controle de larva/

- de novas vacinas/ de desenvolvimento de vacinas/ de novos antivirais como possíveis tratamentos/ de anti-inflamatórios...

- tem sido feito de tudo no Brasil/

- por definição/ a chance de uma coisa que já está funcionando dar certo é menos de 1\%/ então/ por definição/ nós vamos errar mesmo/

- quanto mais a gente trabalhar/maior chance de dar certo/ especialmente para uma doença que não é estudada de forma eficaz há muito tempo/

- o país é um dos principais países que estuda dengue/ é um dos principais países em que dengue é vista como importante pela ciência/

- o governo brasileiro tem injetado dinheiro em dengue/ a gente fica orgulhoso/ mas quando você compara com os do governo americano ou europeu/ é nada/é uma gota no oceano/ é muito pouco/ mas/ é melhor que nada/

- eu acho que os movimentos estão na direção certa/ então/ é feito muita coisa/ mas vai demorar a chegar/

- eu entendo a ansiedade das pessoas/porque as pessoas estão adoecendo/ estão morrendo/

- a possibilidade de morte é pequena/ mas eu vi uma pergunta/ "é caro dengue?"/ é muito caro!/ você ficar em casa e não trabalhar é caro/ você tem como medir isto/

- dengue no Brasil/ em uma cidade/ é uma das principais doenças infecciosas que existem/ o custo dela é muito alto/ então/ tem sido feito muita coisa/ mas falta muito/ nós vamos demorar/ sou otimista, viu!

Fonte: Elaborado pela autora.

\subsection{Ao final do debate, a opinião do público participante}

O caderno de opiniões ficou disponível a todos os presentes no Centro Cultural durante os programas. Inicialmente o público participante preenchia as informações solicitadas no caderno de assinaturas. Quando o programa chegava ao terceiro bloco, o caderno de opiniões começava a circular e o público era convidado a escrever, se quisesse, suas impressões, opiniões e críticas a respeito do projeto. 
Não era necessário assinar, apenas se expressar.

As manifestações abaixo representam, portanto, algumas opiniões do público participante $^{10}$ nos momentos finais da transmissão do programa Ciência e Dengue. Outras opiniões a respeito da mesma noite foram inseridas no decorrer do texto.

A proposta de colocar esses registros aquil ${ }^{11}$ representou uma espécie de fechamento das informações, dados e fatos ocorridos nesse debate.

O projeto é oportuno, provando que a ciência é simples, necessária e que deve ser "transportada" dos laboratórios de pesquisa, para as praças e ruas numa linguagem popular...

Gosto no encontro o propiciar aproximações. Isso amplia o debate. Aproximar pessoas de interesses diversos para se conter uma ideia própria da ciência: expansão. O resto é amassar para dentro: buraco negro.

O projeto favorece a discussão de vários pontos de vista, sem desqualificar os diferentes tipos de conhecimentos, além de propiciar a participação de maneira interativa.

10 Caderno de opiniões do Barômetro Ciência e Dengue, 14 abr. 2011.

11 As opiniões listadas aqui se apresentam do jeito que foram escritas no caderno de opiniões. 


\section{RESULTADOS E CONCLUSÕES}

\subsection{Mapeamento geral das categorias de temas e subtemas}

O mapeamento geral apresentado no Quadro 29 correspondeu ao levantamento de temas e subtemas categorizados de acordo com "imagens da ciência", realizado na Análise II, e ao tempo decorrido para se discutir sobre os assuntos neles inseridos. Cada mapeamento de tema foi acompanhado pelos subtemas levantados durante seu processo discursivo.

O quadro trouxe indicações interessantes. Do ponto de vista das categorias de "imagens da ciência" propostas na pesquisa, independente do assunto discutido, o maior tempo gasto na interação foi dedicado às questões relacionadas à Metodologia científica.

Ainda tendo as categorias como referência, foi possível perceber que o processo discursivo que se desenrolou foi permeado, em sua maioria, por outras categorias, outros discursos. Não foi um processo esquematizado, planejado por uma sequência de ideias, mas, pelo contrário, permitiu que o discurso fosse atravessado por diferentes questões relacionadas ao tema.

As interações discursivas instauradas no debate se distanciaram, por exemplo, das práticas da sala de aula, da palestra, da conferência. O quadro se apresentou em sequência cronológica próxima do tempo real e por isso demonstrou $o$ ir e vir de temas e subtemas e, consequentemente, das categorias das imagens da ciência, de acordo com a ordem em que surgiram no debate. $O$ quadro com 0 levantamento de temas e subtemas categorizados acompanhou, parcialmente, a sequência do quadro de narrativas, uma vez que a análise temática é incapaz de cobrir todas as múltiplas interações discursivas ocorridas durante o programa. Essa sequência demonstrou o dinamismo que o dispositivo criado, o DPM, proporcionou para o debate e a quantidade de temas e subtemas discutidos em torno do assunto. As categorias ora eram temas, ora eram subtemas na interação.

A categoria Metodologia Científica foi discutida por um tempo maior (13:08) do que as demais, contabilizados em minutos e segundos. As categorias Epidemia da doença e Pesquisa científica vieram em seguida (respectivamente, 05:45 e 04:36). Os assuntos relacionados às três categorias foram, respectivamente - 0 diagnóstico da doença, os casos de dengue e aos estudos e pesquisas relacionados à doença. A complexidade do processo de diagnóstico da doença da parte da 
ciência se refletiu nas medidas que a população toma por conta própria para, primeiro saber se tem a doença, segundo, tratar-se. Decorreram daí as categorias na sequência - Mitos (04:12), Saberes Populares (03:58) e Entendimento público da ciência (03:33). Em seguida, vieram as categorias Ensino de ciências (03:25) e, em menor tempo, Linguagem científica (01:44). Os tempos totais de cada categoria se encontram no Quadro 31.

A categoria "Metodologia científica" apresentou ocorrências tanto nos assuntos levantados nos temas quanto nos subtemas. Ao estabelecer a relação entre as categorias e os conteúdos registrados nos temas e subtemas que vieram do quadro de narrativas, foi possível verificar a recorrência dessa categoria. As transcrições do quadro de narrativas relacionadas a ela refletiram problemas, conflitos e dúvidas da esfera da ciência e da esfera da sociedade. A ocorrência dessa categoria superou o tempo médio extraído da relação entre o tempo total do programa e o número de temas categorizados. Dos oito temas categorizados com ocorrências expressivas nas interações e os 83 minutos de debate, os assuntos relacionados à categoria Metodologia científica foram discutidos acima do tempo médio que foi de 10:38 minutos (QUADRO 32).

O médico deixou claro, desde o início do programa, a dificuldade que existe em lidar com a doença Dengue, seja do ponto de vista científico, seja do ponto de vista da população. O médico trouxe em seu discurso a complexidade de problemas que existem na abordagem da doença desde a pesquisa, passando pelos procedimentos de diagnóstico e tratamento, pelos procedimentos internos de validação do conhecimento científico e da relação disso com outras instâncias da sociedade como o governo, pelas estratégias nos períodos de epidemias, pelas dificuldades de comunicação com a sociedade, pelos caminhos alternativos que a sociedade toma porque não se sente amparada pela ciência, pelas questões de financiamento para pesquisa, dentre tantas outras questões.

Os procedimentos da ciência, seus métodos, seus critérios, na maioria das vezes, excessivamente rigorosos, não chegam à população de forma simples, inteligível. Essa é uma parte do processo que a sociedade parece desconhecer.

A categoria que prosseguiu em tempo de ocorrência, "Epidemia da doença", refletiu os problemas discutidos na primeira. Epidemia significa que a população foi maciçamente atingida pelo problema. As metodologias, por mais rigorosas que fossem, não deram conta da situação. A ciência, que de alguma forma seria um 
porto seguro nesses momentos, não deu conta de resolver o problema. Por mais que tenham sido feito estudos e pesquisas, por mais que o representante da ciência tenha trazido esses dados para o debate, daí a terceira categoria em termos de tempo, a "Pesquisa científica", a ciência ainda não deu conta do problema. O fato mais interessante ocorrido nessa categoria se deu mais ao final do programa, quando o médico fez um resumo do que tem sido feito no Brasil em relação aos estudos, à pesquisa sobre Dengue. Foram mais de quatro minutos de fala que deram um apanhado geral do cenário da pesquisa com tópicos que foram da pesquisa científica à segurança e eficácia, do crescimento da doença aos investimentos aqui e no exterior, da comunicação pública da ciência ao sistema educacional, do desenvolvimento das vacinas às relações com o governo. Ele fez críticas aos canais de comunicação da academia, ao sistema educacional e a resultante de tudo isso, a tímida massa crítica. No meio dessa abordagem crítica, ele falou do desenvolvimento de formas de conversar com as pessoas. $O$ médico fez uma síntese da trajetória do conhecimento científico, do seu contexto de produção até chegar ao conhecimento das pessoas.

$\mathrm{Na}$ sequência das categorias, prosseguiram Mitos e Saberes populares. A sociedade, diante das dificuldades de entendimento advindas das dificuldades de comunicação, procura vias alternativas para lidar com o problema. O governo, a terceira instância relacionada ao problema da Dengue, parece também buscar rotas alternativas. Provém daí mitos, como o fumacê, uma medida comum adotada pelas administrações municipais, mesclados aos saberes populares como os chás milagrosos, os alimentos que têm o poder de curar, entre outros.

A categoria "Entendimento público da ciência" surgiu em diversos pontos do debate, mas teve um momento interessante relacionado a ela. Foi perguntado aos debatedores sobre os cuidados que tomavam em casa para prevenir a Dengue. No discurso a respeito dos cuidados em casa, da diarista, apareceu o discurso das campanhas veiculadas na mídia e o discurso da escola. No discurso da dona de casa, apareceu o discurso das campanhas veiculadas na mídia e da presença dos agentes sanitários nos domicílios. No discurso do médico, apareceu o discurso respaldado por um estudo, por índices de uma pesquisa feita pela prefeitura da cidade de Belo Horizonte. Na fala dos três está presente o estudo feito pela prefeitura da cidade que chegou à população pelas campanhas veiculadas na mídia televisiva, impressa e radiofônica, dentre outros. 
Os três falaram das "pessoas". Para a diarista, as pessoas estão tendo consciência, para a dona de casa, as pessoas têm falta de consideração, para o médico, as pessoas dizem uma coisa na hora do discurso e na realidade o que fazem não tem sido suficiente.

A escola ocupou seu lugar nesse complicado fluxo de comunicação no que tangiu à prevenção da doença através das aulas de ciências, na categoria "Ensino de ciências", com reflexos em locais onde a infraestrutura pública é um problema. Medidas de prevenção ensinadas na escola foram transmitidas para as famílias dos alunos de forma prática.

A última categoria foi a "Linguagem científica", assunto que foi abordado na primeira participação do médico e que retornou no terceiro bloco do programa de forma bem específica.

Se as categorias de "imagens da ciência" apontadas nos temas indicaram a diversidade de assuntos que emergiram no debate, outras categorias que apareceram de forma pontual nos subtemas enriqueceram ainda mais essa diversidade.

Dentre elas, veio a questão do Tempo. O que significa o fator Tempo para ciência, para a sociedade, para o governo? Para a ciência, vinte anos é pouco, para a sociedade, sete dias é muito, para o governo, cinco anos é o ideal. Ou, vinte anos para o desenvolvimento de um medicamento é pouco, sete dias para esperar o diagnóstico é muito, cinco anos para fornecer vacinas para a população é o ideal. Como essas três instâncias, ciência, sociedade e governo se comunicam? De onde elas estão falando? Quais são seus interesses? Foi possível perceber que não há dialogo, não há interação, talvez haja um jogo de interesses.

A Validação do conhecimento científico foi outra categoria das "imagens da ciência" que surgiu, exclusivamente pela voz do médico, onde ele deixou claro que é um processo interno da ciência. As normas da ciência não são as normas do governo. O governo não aceita que seu laboratório "achou" a dengue IV (expressão retirada do Subtema 15.1), mas, para a academia, essa descoberta é suficiente para publicação. E também, o teste feito para o repelente do programa de TV não foi válido.

Dessas situações, vieram as categorias Eficácia da ciência, Confiabilidade da ciência, Responsabilidade da ciência. Um teste feito nas condições descritas do programa de TV não é válido, confiável e, consequentemente, propagar o uso do 
repelente é uma atitude irresponsável. "Tirar" do médico um número na base do "chute" é atitude de um "louco". A ciência não apresenta seus resultados por meio de "chutes" (expressões retiradas do Subtema 14.1). Ela tem de ser 100\% confiável (Subtema 4.1).

A eficácia inclui o erro, porque as chances de acerto são menores que 1\%, então, por definição, "a ciência erra mesmo" (Subtema 17.1). Quanto mais a ciência trabalhar de forma eficaz, maiores as chances de dar certo (Subtema 17.1)

A confiabilidade, a eficácia, a responsabilidade incluem custos altos, "proibitivos" (expressão retirada do Subtema 4.1). A inovação científica é cara e temse mais uma categoria, os Custos da ciência.

O popular e barato são vistos com "Ceticismo" e o que não é produto da ciência traz "Riscos" para aqueles que fazem uso. Essas categorias correspondem a alguns dos dilemas da ciência que vieram à tona no debate.

A categoria "Infraestrutura pública" discutiu um ponto delicado e controverso. A relação entre Dengue e pobreza, questionada durante o debate, não associou pobreza à falta de limpeza. Não é porque é pobre que é sujo. A utilização de recursos públicos da parte das instâncias administrativas é o problema. Infraestrutura melhor para quem mora melhor. Melhorias sistemáticas em determinadas regiões justapõem ações paliativas em outras. Enquanto isso, a disseminação da Dengue é um dos problemas mais democráticos.

Ao se comparar os tempos da participação de cada um dos debatedores, ou seja, o Capital de fala, foi possível verificar que o tempo de participação do médico (28 minutos) correspondeu quase ao dobro dos tempos da dona de casa (8 minutos) e da diarista (7 minutos) juntas. A participação delas não se resumiu a responder perguntas, mas a elaborar perguntas para o médico. Ambas tiveram casos de dengue em pessoas próximas, tinham um caso grave para contar, ambas expuseram suas dúvidas e iniciaram suas participações no debate com perguntas dirigidas para o médico. Desse ponto de vista, nenhum dos três debatedores estava "preparado" para o debate. O médico desde o início já anunciou que é muito difícil falar com o público, ou, "é muito assustador falar com a pessoa" (Subtema 1.4), que sua área é da pesquisa, não é necessariamente essa área de combate e de divulgação científica, de comunicação com o público ("até que é/ não é?" expressão retirada do Subtema 1.4), mas já que ele estava lá, ele teria de falar. No momento de sua chegada ao Centro Cultural UFMG, ele avisou que não preparou o 
Power point, sua prática discursiva habitual para falar com o público. A dona de casa e a diarista, por sua vez, queriam esclarecer suas dúvidas em relação à doença. Foi como se as duas debatedoras assumissem a função de repórteres.

O mapeamento geral possibilitou uma visão do panorama discursivo das interações no dispositivo multímoda I(QUADRO 30). A interface digital colaborou muito nesse sentido porque permitiu que o público participante elaborasse perguntas sobre as mais variadas questões relacionadas à Dengue e contou com outro fato interessante, que foi a participação significativa do público através das perguntas feitas pelo microfone.

Quadro 30 - Mapeamento geral de temas e subtemas categorizados e os tempos de debate sobre eles no programa

\begin{tabular}{|c|c|c|c|}
\hline $\begin{array}{c}\text { Tempo/ } \\
\text { duração em } \\
\text { minutos e } \\
\text { segundos }\end{array}$ & $\begin{array}{l}\text { Número } \\
\text { dos } \\
\text { Temas }\end{array}$ & $\begin{array}{c}\text { Temas } \\
\text { categorizados }\end{array}$ & Subtemas categorizados \\
\hline $02: 57$ & 1 & $\begin{array}{l}\text { Metodologia } \\
\text { científica }\end{array}$ & $\begin{array}{l}\text { Dificuldades da ciência dentro e fora do campo } \\
\text { científico/ Papel do cientista/ Linguagem da } \\
\text { ciência/ Pesquisa científica/ Estratégias de } \\
\text { comunicação pública da ciência }\end{array}$ \\
\hline $01: 58$ & 2 & Epidemia da doença & Metodologia científica (diagnóstico da dengue) \\
\hline 01:45 & 3 & $\begin{array}{l}\text { Metodologia } \\
\text { científica }\end{array}$ & Metodologia científica (diagnóstico da dengue) \\
\hline 03:15 & 4 & $\begin{array}{l}\text { Metodologia } \\
\text { científica } \\
\text { (diagnóstico da } \\
\text { dengue) }\end{array}$ & $\begin{array}{l}\text { Altos custos da inovação na pesquisa científica/ } \\
\text { Tecnologia importada/ Importação de } \\
\text { tecnologia/ Cientificamente confiável/ } \\
\text { Confiabilidade da ciência/ Metodologia científica } \\
\text { (tratamento da dengue) }\end{array}$ \\
\hline 00:53 & 5 & $\begin{array}{l}\text { Metodologia } \\
\text { científica } \\
\text { (diagnóstico da } \\
\text { doença) }\end{array}$ & $\begin{array}{l}\text { Metodologia científica/ Automedicação/ Tempo } \\
\text { da ciência x Tempo da sociedade/ (Autoridade } \\
\text { da ciência) }\end{array}$ \\
\hline 02:12 & 6 & $\begin{array}{l}\text { Metodologia } \\
\text { científica } \\
\text { (diagnóstico da } \\
\text { dengue/ discurso da } \\
\text { prática escolar) }\end{array}$ & $\begin{array}{l}\text { Metodologia científica (diagnóstico da dengue)/ } \\
\text { Entendimento público da ciência (sob o olhar do } \\
\text { médico - saberes populares/ automedicação) }\end{array}$ \\
\hline 01:11 & 7 & Saberes populares & $\begin{array}{l}\text { Comunicação pública da ciência - Teste } \\
\text { respaldado pela academia/ Baixo custo/ } \\
\text { Saberes populares }\end{array}$ \\
\hline 01:08 & 8 & Saberes populares & $\begin{array}{l}\text { Validade da pesquisa científica/ Metodologia } \\
\text { científica/ Confiabilidade da ciência/ Ceticismo } \\
\text { em relação ao popular e barato/ Ciência e } \\
\text { instâncias governamentais/ Ciência e } \\
\text { sociedade/ Riscos em relação ao que não é } \\
\text { produto da ciência/ Responsabilidade da ciência }\end{array}$ \\
\hline
\end{tabular}


(continuação)

\begin{tabular}{|c|c|c|c|}
\hline $\begin{array}{l}\text { Tempo/ } \\
\text { duração em } \\
\text { minutos e } \\
\text { segundos }\end{array}$ & $\begin{array}{l}\text { Número } \\
\text { dos } \\
\text { Temas }\end{array}$ & $\begin{array}{c}\text { Temas } \\
\text { categorizados }\end{array}$ & Subtemas categorizados \\
\hline 03:33 & 9 & $\begin{array}{l}\text { Entendimento } \\
\text { público da ciência }\end{array}$ & $\begin{array}{l}\text { Ensino de ciências (a escola)/ Aplicação da } \\
\text { ciência (remédio)/ Entendimento público da } \\
\text { ciência (mobilização da população)/ O discurso } \\
\text { da ciência x o discurso da prática }\end{array}$ \\
\hline 03:12 & $10 \mathrm{~A}$ & Mitos & $\begin{array}{l}\text { Entendimento público da ciência/ Mitos/ } \\
\text { Saberes populares }\end{array}$ \\
\hline 01:00 & $10 \mathrm{~B}$ & Mitos & $\begin{array}{l}\text { Saberes populares/ (Pesquisa científica/ } \\
\text { Eficácia da ciência/ Confiabilidade da ciência) }\end{array}$ \\
\hline 01:39 & $10 \mathrm{C}$ & Saberes populares & Saberes populares/ Mitos \\
\hline 01:42 & 11 & $\begin{array}{l}\text { Ensino de ciências/ } \\
\text { Entendimento } \\
\text { público da ciência }\end{array}$ & $\begin{array}{l}\text { Comunicação pública da ciência (Pesquisa } \\
\text { científica/ Tipos ou formas de comunicação } \\
\text { pública da ciência) }\end{array}$ \\
\hline 03:47 & 12 & $\begin{array}{l}\text { Epidemia e } \\
\text { Condições } \\
\text { socioeconômicas e } \\
\text { culturais }\end{array}$ & Infraestrutura pública \\
\hline 01:43 & 13 & Ensino de ciências & $\begin{array}{l}\text { Ensino de ciências (projetos na escola/ } \\
\text { conscientização de gerações futuras/ mudança } \\
\text { de hábito) }\end{array}$ \\
\hline 02:06 & 14 & $\begin{array}{l}\text { Metodologia } \\
\text { científica }\end{array}$ & $\begin{array}{l}\text { Metodologia científica (Relação Ciência x } \\
\text { Governo/ Tempo da ciência x Tempo da } \\
\text { sociedade) }\end{array}$ \\
\hline 01:44 & 15 & $\begin{array}{l}\text { Linguagem científica/ } \\
\text { Entendimento } \\
\text { público da ciência }\end{array}$ & $\begin{array}{l}\text { Metodologia científica/ Relação Ciência x } \\
\text { Governo/ Contexto de produção da ciência/ } \\
\text { Validação da ciência }\end{array}$ \\
\hline 02:17 & 16 & $\begin{array}{l}\text { Pesquisa científica/ } \\
\text { Comunicação } \\
\text { pública da ciência }\end{array}$ & $\begin{array}{l}\text { Confiabilidade da ciência/ Responsabilidade da } \\
\text { ciência/ Validação da ciência/ Metodologia } \\
\text { científica/ Tempo da ciência/ Investimento na } \\
\text { ciência/ Custo da ciência }\end{array}$ \\
\hline 02:19 & 17 & Pesquisa científica & $\begin{array}{l}\text { Comunicação pública da ciência/ Entendimento } \\
\text { público da ciência/ Ensino de ciências/ } \\
\text { Pesquisa científica/ Eficácia e falibilidade da } \\
\text { ciência/ Inovação/ Custo da pesquisa científica/ } \\
\text { Relevância de temas da ciência x Contexto de } \\
\text { produção da ciência }\end{array}$ \\
\hline
\end{tabular}

Fonte: Elaborado pela autora.

Quadro 31 - Tempos de debate dos temas e subtemas categorizados, no programa

\begin{tabular}{|l|c|}
\hline \multicolumn{2}{|c|}{ Tempos totais (minutos e segundos) } \\
\hline Metodologia científica & $13: 08$ \\
\hline Epidemia da doença & $05: 45$ \\
\hline Pesquisa científica & $04: 36$ \\
\hline Mitos & $04: 12$ \\
\hline Saberes populares & $03: 58$ \\
\hline Entendimento público da ciência & $03: 33$ \\
\hline Ensino de ciências & $03: 25$ \\
\hline Linguagem científica & $01: 44$ \\
\hline
\end{tabular}

Fonte: Elaborado pela autora. 
Quadro 32 - Relação entre o tempo total do programa e o número de temas categorizados

\begin{tabular}{|l|c|}
\hline Tempo total do programa & 83 minutos \\
\hline Número de temas categorizados & 8 \\
\hline $\begin{array}{l}\text { Tempo médio - tempo total do programa / número de temas } \\
\text { categorizados }\end{array}$ & $10: 38$ \\
\hline Tempo categoria Metodologia científica & $13: 08$ \\
\hline
\end{tabular}

Fonte: Elaborado pela autora.

\subsection{A ciência na voz dos atores do Barômetro Ciência e Dengue}

A seguir, apresentam-se as categorias das "imagens da ciência" levantadas a partir da análise temática e dos respectivos posicionamentos dos representantes da comunidade científica e da sociedade civil em relação a questões que envolvem o campo da ciência no debate Ciência e Dengue. Os trechos foram retirados do levantamento temático feito a partir das interações.

Os trechos se apresentam da seguinte maneira:

1ํ. Categoria "imagens da ciência" levantadas na Análise II, em negrito;

2 을 Origem da interação: Comunidade científica e/ou Sociedade civil;

3ํ A interação: trechos ilustrativos com referência do tema ou subtema, em itálico.

Algumas categorias não foram manifestadas pela Sociedade civil.

Entre parênteses, para localizar na interação, estão os números dos temas e subtemas que podem ser consultados no capítulo de Temas e Subtemas.

\section{1- $O$ cientista ( $O$ papel do cientista)}

Comunidade científica

- a abordagem do cientista para os temas dengue e para qualquer tema é um pouco mais crítica que a abordagem das pessoas porque ele tem que questionar e questionar ou não a utilidade de determinada atitude (Subtema 1.4)

- ele se dedica mais à área da pesquisa/ de estudo (Subtema 1.4)

- sua área não é necessariamente essa área de combate/ e de divulgação científical de divulgação até que é/ não é? ... de comunicação com o público (Subtema 1.4) 


\section{2- A sociedade civil}

Comunidade científica

- é engraçado as pessoas não ouvirem isso através da mídia (estudos sobre dengue no Brasil)/ isto é obviamente uma incompetência dos órgãos da universidade em dizer que muita está sendo feital é muita coisa relativa porque a massa crítica no Brasil é pequena (Subtema 17.1)

- para um leigo/ às vezes dengue se parece com tudo (Subtema 6.2)

- porque a aspirina faz com que as pessoas leigas chamam de ralear o sangue (Subtema 6.2)

\section{3- Contexto de produção da ciência}

Comunidade científica

- o país é um dos principais países que estuda dengue/ é um dos principais países em que dengue é vista como importante pela ciência (Subtema 17.1)

- o governo brasileiro tem injetado dinheiro em dengue/ a gente fica orgulhoso/ mas quando você compara com os do governo americano ou europeu/ é nada/ é uma gota no oceano/ é muito pouco/ mas/ é melhor que nada (Subtema 17.1)

\section{4- Confiabilidade na ciência}

Comunidade científica

- já tem dois anos/ você tem métodos de fazer o diagnóstico mais rápido/ mas o diagnóstico não é 100\% confiável (Subtema 4.1)

Sociedade civil

- ele foi testado na hora com um médico e uma outra pessoa da faculdade lá do Rio de Janeiro (Subtema 7.1)

\section{5- Responsabilidade da Ciência x Sociedade x Governo}

Comunidade científica

- o problema da dengue é de todo mundo/ mas também é da prefeitural é do estado que é um pouco que eu não vejo nas campanhas/ é um problema das pessoas/ mas não é meu/ é do estado (Subtema 8.2)

- (vacina contra a dengue) mas o ministro da saúde falou no ano passado que em cinco anos isso aconteceria/ ele é louco/ eu como ministro não falaria isso nunca 
(Subtema 14.1)

- (vacina contra a dengue) vocês não vão conseguir tirar nenhum número de mim de jeito nenhum/ tá?/ seria um chute qualquer número que eu dissesse (Subtema 14.1)

\section{6- Eficácia da ciência}

Comunidade científica

- quando você fala em tratar um ser humano com um remédio/ com vacina/ a coisa mais importante que você tem que ter em mente chama-segurança/ você tem que ter cinco coisas/ as quatro primeiras são segurança e depois a eficácia/ então/ para eu testar alguma coisa/ eu tenho que comprovar que é seguro muitas vezes (Subtema 16.1)

- tem sido feito de tudo no Brasil/ pode definição/ a chance de uma coisa que já está funcionando dar certo é menos de 1\%/ então/ por definição/ nós vamos errar mesmo (Subtema 17.1)

\section{7- Validação da ciência}

Comunidade científica

- só que para o Estado aceitar que tem dengue/ ele tem que cumprir algumas normas/ e/ essas normas não são/ às vezes/ as normas que os cientistas usam (Subtema 15.1)

- então/ em nosso laboratório/ já achamos dengue-IV/ e o secretário de saúde acha que não é suficiente/ é suficiente para publicar e tudo/ mas não é suficiente para o Estado/ porque as normas são diferentes (Subtema 15.1)

\section{8- Custo da ciência}

Comunidade científica

- você colocar um novo exame no sistema público tem um custo/ às vezes essa tecnologia é importada/ o custo passa a ser proibitivo (Subtema 4.1)

Sociedade civil

- além de ser muito fácil (o repelente natural veiculado no programa de TV)/ é um cheirinho muito gostoso e barato (Subtema 7.1) 


\section{9- Metodologia científica}

Comunidade científica

- o que você mede não é o vírus da dengue/ você mede a resposta do indivíduo ao vírus (Subtema 3.1)

- (o diagnóstico de dengue) ele é de exclusão até você confirmar/ então/.../ é muito diferente de outras doenças (Subtema 6.1)

- qualquer doença/ quanto mais opções de controle você tem/ melhor para você/ melhor suas opções e a sua estratégia (Subtema 14.1)

Sociedade civil

- não há um jeito mais fácil de a pessoa descobrir? (Tema 4)

- então/ o menino morreu porque não fizeram o exame antes/ por que não tentaram descobrir antes? (Subtema 2.2)

\section{0- Linguagem científica}

Comunidade científica

- porque a nossa linguagem é muito diferente/ a linguagem nossa é muito difícil (Subtema 1.4)

Sociedade civil

- esta é uma dúvida minha e dúvida de quem está aqui também: quando aparece dengue-I/ dengue-II/ dengue-III/ dengue-IV ... o que é isto? (Tema 15)

\section{1- Comunicação pública da ciência}

Comunidade científica

- a parte que ele se dedica (o cientista) chega pouco às pessoas/ é muito assustador falar com a pessoa (Tema 1.5)

- (estudos de dengue no Brasil) eu acho que é uma coisa que nós estamos tentando ... é engraçado as pessoas não ouvirem isso através da mídial (Tema 17.1)

Sociedade civil

- vi no programa da ... (receita de repelente natural contra a dengue divulgado em um programa de TV matinal) (Subtema 7.1) 


\section{2- Entendimento público da ciência}

Comunidade científica

- o individual não tem sido suficiente/ porque as pessoas/ na hora do discurso/ dizem que tomam o cuidado necessário/ mas [a dengue] não está diminuindo (Subtema 9.3)

Sociedade civil

- me desculpe/ o senhor não respondeu a minha pergunta (Subtema 5.1)

- ele meio que respondeu sim (Subtema 5.2)

\section{3- Epidemia da doença}

Comunidade científica

- tem epidemias de dengue a cada quatro/três a seis anos/ a dengue-IV veio para o Brasil agora/ então/ é possível que haja uma epidemia no ano que vem ou no outro (Subtema 9.3)

\section{Sociedade civil}

- a senhora teve uma neta/ duas cunhadas/ um filho e uma nora que contraíram dengue/ e o caso mais sério/ que foi do neto da senhora/ [...]/ não é? (Tema 2)

- Nós temos também aqui a dona [...]/ que trabalha como diarista e mora em [...]/no bairro [...]/ e a senhora/ o seu filho e o seu irmão já tiveram dengue/ como é a dengue lá no seu bairro? Horrível/ [risadas]/ agora já melhorou muito/ sabe? (Tema 2)

\section{4- Mitos}

Comunidade científica

- eu queria ouvir alguns mitos/ porque [...] tem muito de verdade no que as pessoas dizem/ eu acho que existem alguns exageros/ mas o do fumacê é fantástico (Subtema 10.1 A)

Sociedade civil

- eu também ouvi falar/ como diz a gíria popular/ que se a pessoa comesse 
bastante [inhame]/ isto também diminuiria/ ou então/ você não iria pegar a dengue (Subtema 10.1 B)

\section{5- Saberes populares}

Comunidade científica (ceticismo)

- eu tenho muito medo de receitas populares (Subtema 8.1)

Sociedade civil (crença/descrença na ciência)

- tomei um chá fortíssimo/ com limão/ cebola/ alho e mel/ com três dias eu estava ótima (Subtema 10.2 A)

\section{6- Infraestrutura pública}

Comunidade científica

- (dengue é) absolutamente democrátical [...]/ ela não escolhe lugar/ então o acesso do serviço público às regiões mais pobres/ às vezes/ é complicado (Subtema 12.3)

Sociedade civil

- lá a gente não tem esse negócio que ... igual ela falou comigo/ "você joga fumacê lá no seu bairro?"/ o que eu vejo é o pessoal de seis em seis meses que passa lál joga um remedinho e pronto (Subtema 12.4)

- não é questão de pobreza/ é questão do meio ambiente que as pessoas/ principalmente a prefeitura .../ enquanto ela arruma milhões de vezes a Praça da Liberdade o outro nem asfalto tem (Subtema 12.1)

\section{7- Ensino de ciências}

Comunidade científica

- não há uma interação com as crianças/ há um conhecimento muito grande/ mas não sei se está sendo transmitido da melhor forma (Subtema 11.2)

Sociedade civil

- na aula de ciências/e as crianças/uma vez por mês/saem limpando as ruas/ elas saem com os lixinhos/ elas vão com os professores de ciências (Subtema 13.1) 


\section{8- Discurso da prática escolar}

Comunidade científica

- então/ voltarei um pouquinho/ o diagnóstico de dengue tem que estar em um contexto (Tema 6)

\section{9- Tempo da ciência $x$ Tempo da sociedade $x$ Tempo do governo}

Comunidade científica

- as vacinas devem chegar em um prazo de em torno de dez a vinte anos/ isto é rápido (Subtema 16.1)

- eu acho que as perspectivas são boas/ mas é um intervalo que para a maioria das pessoas é um intervalo longo/ mas que para a ciência é um intervalo bastante curto/ é uma visão diferente (Subtema 14.1)

- (vacina contra a dengue) mas o ministro da saúde falou ano passado que em cinco anos isso aconteceria/ ele é louco/ eu como ministro não falaria isso nunca (Subtema 14.1)

Sociedade civil

- sete dias para quem tem os sintomas/ é uma coisa que demora muito (Subtema 2.2)

- aí eles falam/ daí a sete dias você volta/[...] aí/ deu sete dias/ você faz o exame/ não constou que é dengue/ [...]/ mas se for dengue você demora sete dias (Subtema 2.2)

- o que eu vejo é o pessoal de seis em seis meses que passa lál joga um remedinho e pronto (Subtema 12.4)

\section{0- Respaldo da comunidade científica}

Comunidade científica

- (o repelente natural) foi feito no (no programa de TV) francamente não é válido (Subtema 8.1)

Sociedade civil

- eles dizem que a Aspirina é algo que vai contra a cura (Subtema 5.2.1) 
Quadro 33 - Ocorrências das imagens da ciência presentes no discurso da Comunidade científica e da Sociedade civil

\begin{tabular}{|l|c|c|}
\hline \multicolumn{1}{|c|}{ Imagens da ciência } & $\begin{array}{c}\text { Comunidade } \\
\text { científica }\end{array}$ & $\begin{array}{c}\text { Sociedade } \\
\text { civil }\end{array}$ \\
\hline O cientista (o papel do cientista) & $\mathrm{X}$ & \\
\hline A sociedade civil & $\mathrm{X}$ & \\
\hline Contexto de produção da ciência & $\mathrm{X}$ & \\
\hline Confiabilidade na ciência & $\mathrm{X}$ & $\mathrm{X}$ \\
\hline Responsabilidade da ciência/sociedade/governo & $\mathrm{X}$ & \\
\hline Eficácia da ciência & $\mathrm{X}$ & \\
\hline Validação da ciência & $\mathrm{X}$ & \\
\hline Custo da ciência & $\mathrm{X}$ & $\mathrm{X}$ \\
\hline Metodologia científica & $\mathrm{X}$ & $\mathrm{X}$ \\
\hline Linguagem científica & $\mathrm{X}$ & $\mathrm{X}$ \\
\hline Comunicação pública da ciência & $\mathrm{X}$ & $\mathrm{X}$ \\
\hline Entendimento público da ciência & $\mathrm{X}$ & $\mathrm{X}$ \\
\hline Epidemia da doença & $\mathrm{X}$ & $\mathrm{X}$ \\
\hline Mitos & $\mathrm{X}$ & $\mathrm{X}$ \\
\hline Saberes populares (Ceticismo/ Crença e Descrença na & $\mathrm{X}$ & $\mathrm{X}$ \\
ciência) & $\mathrm{X}$ & $\mathrm{X}$ \\
\hline Infraestrutura pública & $\mathrm{X}$ & $\mathrm{X}$ \\
\hline Ensino de ciências & $\mathrm{X}$ & \\
\hline Discurso da prática escolar & $\mathrm{X}$ & $\mathrm{X}$ \\
\hline Tempo da ciência/da sociedade/do governo & $\mathrm{X}$ & $\mathrm{X}$ \\
\hline Respaldo da ciência & & \\
\hline
\end{tabular}

Fonte: Elaborado pela autora.

\subsection{A comunidade científica e a ciência}

A comunidade científica teve uma representatividade pequena em números no debate, embora significativa. Foi um representante da comunidade científica, enquanto a sociedade civil se viu representada pela dona de casa, a diarista, o público participante e o músico, que não apenas tocou e cantou, mas teve duas participações interessantes no debate. Especialmente naquela noite, estavam presentes 37 pessoas na plateia.

O médico possui título de doutorado em Imunofarmacologia por uma universidade europeia, professor titular das áreas de bioquímica e imunologia de uma universidade pública, pesquisador do CNPq, membro de associações científicas nacionais e internacionais. É membro também do corpo editorial de periódicos acadêmicos de alto impacto. Ele possui experiência na área de farmacologia, com ênfase em Farmacologia dos Mediadores do Processo Inflamatório, com atuação 
nos seguintes temas: inflamação, quimiocinas e recrutamento celular.

Pode-se dizer que seu currículo caracteriza o perfil dos cientistas em atuação nos dias de hoje nos grandes centros universitários. Desde o início do programa, ele demarcou seu lugar, ou seja, sua área não é necessariamente a área do combate, da divulgação científica, da comunicação pública. Sua área é a do estudo, da pesquisa. Ele se utilizou de alguns argumentos para caracterizar "esse" lugar - a linguagem da ciência é difícil, precisa ser decodificada, a abordagem do cientista para qualquer tema é mais crítica do que a abordagem das pessoas e a parte a que ele se dedica chega pouco às pessoas. Ele polarizou a relação ciência e sociedade.

Mesmo ao falar de um "lugar" distante, ele acabou por concordar que pode sim se comunicar com o público e que esse "lugar" de onde ele fala possui sua complexidade e seus conflitos. Ele não se preocupou em colocar a ciência em um pedestal, pelo contrário, expôs o tempo todo suas dificuldades, suas insuficiências, seus erros, suas incapacidades, seus conflitos internos e externos. Esse foi um dos pontos mais positivos de sua participação.

Das categorias de "imagens da ciência" emergentes da análise, o cientista transitou por todas, fato que possibilitou a construção de uma noção da ciência como falível, não linear, nem sempre bem sucedida, não inteligível, não bem relacionada com outras instâncias, não interagida com a sociedade de modo geral. $\mathrm{A}$ ciência de que ele fala apresenta falhas, conflitos, caminhos tortuosos e depende do jogo de relações com diferentes instâncias para seguir em frente. Podem ser esses os motivos que contribuíram para o distanciamento entre ciência e sociedade.

Mesmo ao admitir as imperfeições da ciência, ele não se mostrou aberto para dialogar com os saberes populares. Sua posição foi de ceticismo e medo (Subtemas 8.1/ 16.1). Essa atitude acentuou ainda mais a polarização ciência e sociedade.

\subsection{A sociedade civil e a ciência}

Os posicionamentos da sociedade civil tenderam a ser um reflexo dos posicionamentos da comunidade científica. Enquanto o discurso do médico transitou pelas categorias propostas, mesmo algumas vezes em posição contrária, cética e crítica, o discurso dos representantes da sociedade civil não entrou em determinadas searas do campo científico.

As debatedoras da sociedade civil e o público participante não tocaram em questões pertinentes ao cientista e seu papel, ao contexto de produção da ciência, à 
responsabilidade e eficácia da ciência e à validação do conhecimento científico.

As categorias das "imagens da ciência" presentes no discurso dos representantes da sociedade civil se relacionam a questões próximas de suas experiências pessoais. A sociedade não experimenta a ciência, não vivencia as experiências científicas, as descobertas científicas. A sociedade toma conhecimento de seus resultados, da forma como interessa à academia divulgá-los. A ciência estreita um pouco os laços com a sociedade quando os problemas ganham a esfera pública. A epidemia de dengue é um desses casos.

A dengue, como foi dito, é democrática, alastra-se por toda parte, e atinge todas as camadas sociais. Nesse caso, ela não pertence apenas à esfera da saúde, mas às esferas social, política e administrativa.

Os problemas de abordagem da dengue são tantos que inviabilizam o diálogo entre ciência e sociedade, diálogo esse mediado pelo governo. Interesses diversos entraram em jogo e a sociedade ficou perdida em meio a tanta falta de entendimento.

Quando a sociedade lidou com as questões da ciência, ela fez isso de forma ingênua. Um exemplo disso é o repelente. Ele foi testado por um "médico" e por "outra pessoa da faculdade lá do Rio de Janeiro" (expressões retiradas do Subtema 7.1). Isso bastou para que o repelente se tornasse de uso confiável para a dona de casa. O rigor da ciência caiu por terra através de um popular programa de TV.

Os cuidados em tomar Aspirina foi outro exemplo. Segundo o músico, "eles dizem" que tomar esse medicamento é algo que vai contra a cura (Subtema 5.2.1). Eles quem? Quem está por traz dessa afirmação? Esse é um dos cuidados largamente divulgados em relação à automedicação em dengue e aparenta ter certo respaldo da comunidade médica. É um cuidado veiculado na mídia, que demonstra causar certos riscos para quem toma e que as pessoas procuram seguir à risca.

O caso do chá também foi outro exemplo. Após a constatação de que estava com o quadro de sintomas da doença, a doméstica tomou um "chá fortíssimo" e precisou de mais três dias para ficar "ótima" (expressões retiradas do Subtema 10.2 A). Ela apresentou os sintomas que demoram certo tempo para se manifestarem (cinco a seis dias após a picada - http://www.dengue.org.br/dengue_sintomas.html), tomou o chá e, somente após três dias, ela ficou boa. O percurso entre as manifestações dos sintomas, o chá, e ela ter ficado boa correspondem ao ciclo da doença. Mesmo após o médico dizer que ela melhorou com, sem e apesar do chá, 
ela afirmou que teve certeza de que iria sarar (Subtemas 10.3 A/ 10.4 A).

Os outros casos relatados também refletiram essa realidade. Comer "bastante inhame", o "psicológico" que ajuda muito e a automedicação foram outros exemplos dessa situação (Subtemas 10B/ 10C/ 5.2.1/ 6.2).

Porém a questão mais complicada da dengue se concentrou nos procedimentos de seu diagnóstico. Se a falta de comunicação levou à posição de ingenuidade, as dificuldades de se obter o diagnóstico se refletiram nos casos citados anteriormente. O procedimento é complicado para os próprios profissionais que lidam com a doença - é por exclusão. Os sintomas se parecem com os sintomas de várias doenças e os profissionais da área da saúde têm de prosseguir por eliminação. Existem "erros de diagnóstico" e existem "casos que são muito difíceis de diagnosticar" (expressões retiradas do Subtema 6.1). A população vai tender a tomar chá, comer inhame e trabalhar o "psicológico".

O sistema público da saúde, que replica os procedimentos vindos dos estudos, das pesquisas, da academia, não dá conta de amparar a população, de dar segurança, dos casos simples até os mais graves.

O sistema escolar teve um papel importante nessa situação porque orientou as crianças para medidas de prevenção, que acabaram orientando os pais em casa.

Mesmo que a ciência veja com certo ceticismo os saberes populares, foi na direção desses saberes que a população foi buscar soluções para seus problemas. O espaço para o surgimento de novos mitos se ampliará cada vez mais.

Nesse sentido, a ciência é, cada vez mais, uma entidade distante para a sociedade. Ainda que se encontrem para debater, como foi a proposta do "Barômetro - Ciência, café e debate", falta muito para que a ciência compreenda os processos por meio dos quais a sociedade funciona e a sociedade compreenda os processos por meio dos quais a ciência funciona.

Essa talvez seja uma das principais contribuições do "Barômetro", estreitar laços, estimular a comunicação, promover a compreensão de processos.

\subsection{A ciência, a sociedade civil, a comunidade científica, as interações} discursivas públicas, o dispositivo pedagógico multimodal: O Barômetro Ciência, café e debate

O final dessa trajetória de pesquisa faz um convite à reflexão. Elaborar um dispositivo pedagógico multimodal para promover interações discursivas entre 
esferas da sociedade que aparentemente não possuem canais de comunicação entre si não foi uma tarefa fácil. Inserir nesse dispositivo inovações que estimulassem a comunicação e o estreitamento de laços também não consistiu de uma tarefa simples. Todo o esforço de produção e de pesquisa direcionado ao desenvolvimento do "Barômetro" envolveu uma equipe de produção de pelo menos três setores internos da UFMG. E esse esforço foi para produzir eventos mensais, oito por ano. Pode-se dizer que isso foi apenas um começo.

O "Barômetro" representou não somente um projeto inovador, mas teve, em seus objetivos, aspirações ousadas. Promoveu encontros inusitados, por meios inusitados e conseguiu causar o encanto e o engajamento daqueles que dele participaram.

A pesquisa proposta encontrou suas respostas - ciência e sociedade se encontraram para debater, mas ainda precisam aprender a dialogar, a interagir, a se conhecer melhor. Precisam desenvolver o interesse de uma pela outra. Precisam fazer despertar esse interesse.

O Barômetro Ciência e Dengue foi uma amostra significativa do universo das edições do projeto. Seu programa reuniu diferentes segmentos da sociedade, ali representados e convidados a exporem suas ideias, suas opiniões, suas experiências de vida. A pesquisa foi marcada pelo diálogo constante e simultâneo com um referencial teórico balizador das ações. Na reta final, esse diálogo não poderia ser esquecido. Portanto, antes de concluir, segue uma proposta de fechamento entre um e outro, entre o material teórico e o material empírico.

O projeto criado para ser objeto de estudo desta pesquisa, o Café Científico "Barômetro - Ciência, café e debate" se constituiu como um espaço de comunicação pública da ciência e seguiu a linha dos modelos de engajamento público de Lewestein (2003); agregou às regras dos dispositivos pedagógicos de Bernstein (1990) as regras da multimodalidade de que falaram Lauer (2009) e Kress (2004); criou ambientes multimodais em acordo com as concepções de Martin, Daly e Thurston (2005); seus procedimentos de concepção e produção estabeleceram objetivos e metas do design instrucional de Smith e Ragan (1999); suas interações discursivas públicas possibilitaram o levantamento de temas e subtemas da análise temática de Riesmann (2008); seus temas ganharam significados entre os processos de comunicação de seus atores; acabaram encontrando coerência com as palavras de Bensaude-Vincent (2001), ciência e sociedade vivem em mundos diferentes, não 
adentraram na dimensão das arenas públicas, dos cidadãos vigilantes e críticos dos processos da ciência de que relatou Monteiro (2006), e possibilitaram a formação de um quadro de imagens da ciência que Polino (2003) e Izique e Moura (2004) procuraram em sua pesquisas.

A abordagem qualitativa, aliada aos processos do design instrucional e aos procedimentos da análise temática, permitiu o cruzamento do olhar da produção e da pesquisa e atingiram a intimidade das narrativas de Sautet (2006).

A pesquisa chegou à conclusão reescrevendo sua hipótese:

Por meio das interações discursivas públicas entre a comunidade científica e a sociedade civil, promovidas pelo dispositivo pedagógico multimodal criado pelo Projeto "Barômetro - Ciência, café e debate", emergem elementos relacionados ao cientista e seu papel, à sociedade civil e sua relação com a ciência, ao contexto de produção da ciência, à confiabilidade na ciência, à responsabilidade, à eficácia, à validação, ao respaldo, ao custo e ao tempo da ciência e tempo do governo, à metodologia e linguagem científica, à comunicação pública da ciência, ao entendimento público da ciência, aos mitos, ao ceticismo em relação aos saberes populares, à infraestrutura pública relacionada aos problemas da ciência, ao ensino de ciência, da parte da comunidade científica e, elementos relacionados à confiabilidade na ciência, ao custo, ao tempo da ciência e o tempo da sociedade, ao respaldo da ciência, à metodologia e linguagem científica, à comunicação pública da ciência, ao entendimento público da ciência, aos mitos, aos saberes populares e a descrença na ciência, à infraestrutura pública relacionada aos problemas da ciência, ao ensino de ciência, da parte da sociedade civil. 


\section{REFERÊNCIAS}

ARONSON, J. A pragmatic view of thematic analysis. The Qualitative Report, Fort Lauderdale, v. 2, n. 1, spring 1994. Disponível em: <http://www.nova.edu/ssss/QR/ Backlssues/QR2-1/aronson.html>. Acesso em: 25 abr. 2012.

ASSOCIAÇÃO BRASILEIRA DE CENTROS E MUSEUS DE CIÊNCIAS. Informações gerais. São Paulo, 2010. Disponível em: <http://www.abcmc.org.br/ publique1/cgi/cgilua.exe/sys/start.htm?tpl=home>. Acesso em: 06 ago. 2010.

ASSOCIAÇÃO BRASILEIRA DE NORMAS TÉCNICAS. NBR 10520: informação e documentação: citações em documentos: apresentação. Rio de Janeiro: ABNT, 2002.

NBR 14724: informação e documentação: trabalhos acadêmicos: apresentação. Rio de Janeiro: ABNT, 2011.

NBR 6023: informação e documentação: referências: elaboração. Rio de Janeiro: ABNT, 2002.

NBR 6024: numeração progressiva das seções de um documento escrito: apresentação. Rio de Janeiro: ABNT, 2003.

NBR 6027: informação e documentação: sumário: apresentação. Rio de Janeiro: ABNT, 2003.

NBR 6028: informação e documentação: resumo: apresentação. Rio de Janeiro: ABNT, 2003.

BADDREDINE, Z.; BUTY, C.; NASCIMENTO, S. S. Análise temática e análise de discurso em sala de aula de ciências: utilização do software transana. In: ENCONTRO NACIONAL DE PESQUISA EM EDUCAÇÃO EM CIÊNCIAS, VI, 2007, Florianópolis. Anais ... Florianópolis, 2007.

BAGNOLI, F., DALLAS D., PACINI G. Sipping Science with a Science Café. SciCafé; Science in Society, Seventh Framework Programme, 2010. Disponível em: <http://www.scicafe.eu/node/276>. Acesso em: 08 abr. 2013.

BARDIN, L. Análise de conteúdo. Tradução Luís Antero Reto e Augusto Pinheiro. São Paulo: Edições 70, 2011.

BECHARA, E. Moderna gramática portuguesa. Rio de Janeiro: Lucerna, 2004.

BENSAUDE-VINCENT, B. A genealogy of the increasing gap between science and the public. Public Understanding of Science, Thousand Oaks, v. 10, p. 99-113, 2001.

BERNSTEIN, B. El dispositivo pedagógico, reglas constitutivas. In: BERNSTEIN, B. Poder, educación y conciencia: sociología de la transmisión cultural. Barcelona: El Roure, 1990. Cap. 5, p. 101-112. 
BOSSLER, A. P. Indicadores do gênero educativo no programa de rádio ciência na favela. 2004. 275 f. Dissertação (Mestrado em Educação) - Faculdade de Educação da Universidade Federal de Minas Gerais, Belo Horizonte.

BRASIL. Ministério da Ciência e Tecnologia. Percepção pública da ciência e tecnologia. Brasília, 2006. Disponível em:

<http://www.uefs.br/antares/docs/mct.pdf>. Acesso em: 14 ago. 2010.

BUFREM, L. S. et al. Produção científica em Ciência da Informação: análise temática em artigos de revistas brasileiras. Perspectivas em Ciência da Informação, Belo Horizonte, v. 12, n. 1, p. 38-49, jan./abr. 2007.

CANADIAN INSTITUTES OF HEALTH RESEARCH. Cafe scientifique, Toronto, 2010. Disponível em: <http://www.cihr-irsc.gc.ca/e/3495.1html>. Acesso em: 06 ago. 2010.

CAZELLI, S. Divulgação científica em espaços não formais. In: CONGRESSO DA SOCIEDADE DE ZOOLÓGICO DO BRASIL, XXIV, 2000, Belo Horizonte. Anais ... Belo Horizonte: [s.n.], 2000. p. 1-15.

COEN, M. H. Design principles for intelligent environments. In: SYMPOSIUM ON INTELLIGENT ENVIRONMENTS, 1998, California. Annals ... California: Stanford University in Palo Alto, 1998. p. 547-554. Disponível em: <http://www.aaai.org/Pape rs/AAAl/1998/AAAI98-077.pdf > Acesso em: 08 jun. 2012.

COLL, R. K.; LAY, M. C.; TAYLOR, N. Scientists and scientific thinking: understanding scientific thinking through an investigation of scientists views about superstitions and religious beliefs. Eurasia Journal of Mathematics, Science and Technology Education, Ankara, v. 4, n. 3, p. 197-214, 2008. Disponível em: <http:// www.ejmste.com/v4n3/EURASIA_v4n3_Coll.pdf>. Acesso em: 07 dez. 2012.

CONCEPÇÕES sobre cafés científicos, configurações e eventos ao redor do mundo. Cafe Scientifique, British Council, Reino Unido, 2010a. Disponível em: <http://www.britishcouncil.org/science-cafesci.htm>. Acesso em: 05 ago. 2010.

CONCEPÇÕES sobre cafés científicos, configurações e eventos ao redor do mundo. Cafe Scientifique, Lyon, França, 2010b. Disponível em: <http://www.cafescientifique. org/>. Acesso em: 05 ago. 2010.

DANVINA, G.-S. Café scientifique, Manchester: Seasonig a meal with science. Manchester, 2004. Disponível em: <http://www.pcst2004.org/esp/pdf/Parallel_Ses sion_21.pdf>. Acesso em: 08 ago. 2010.

FILATRO, A.; PICONEZ, S. C. B. Design instrucional contextualizado. In: CONGRESSO ABED 2004, 2004, Salvador. Anais ... São Paulo: ABED 2004, 2004. p. 01-08. Disponível em: <http://books.google.com.br/books?id=S60508PlbJUC\&pri ntsec $=$ frontcover \&dq=design+instrucional + contextualizado\&hl=pt-BR\&sa $=X \& e i=J 0$ sd Ua3OFcHe0QHd84DYBg\&ved=0CDcQ6AEwAA>. Acesso em: 19 abr. 2012. 
FRANÇA, Júnia Lessa; VASCONCELLOS, Ana Cristina de. Manual para Normalização de Publicações Técnico-Científicas. 8. ed. rev. e ampl. Belo Horizonte, 2007. 255p.

FUNDAÇÃO OSWALDO CRUZ. Museu da Vida. Informações sobre o Chopp Científico, um Café Científico promovido pelo Museu da Vida em parceria com a Fiocruz. Site Chopp Científico, Rio de Janeiro, 2002. Disponível em: <http://www.museudavida.fiocruz.br/chopp/>. Acesso em: 07 ago. 2010.

GIBBS, Graham. Análise de dados qualitativos. Tradução Roberto Cataldo Costa. Porto Alegre: Artmed, 2009. Coleção Pesquisa Qualitativa.

IBGE, INSTITUTO BRASILEIRO DE GEOGRAFIA E ESTATÍSTICA. Normas de apresentação tabular. 3. ed. Rio de Janeiro: IBGE, 1993.

INSTITUTE DE RECHERCHE POUR LE DÉVELOPPMENT. Informações sobre os eventos de Café Científico. Café Científico, Brasília, 2010. Disponível em: <http://www.brasil.ird.fr/spip.php?article4356>. Acesso em: 06 ago. 2010.

IZIQUE, C.; MOURA, M. Imagens da ciência - Rede ibero-americana de pesquisadores desenvolve índices para avaliar percepção pública do conhecimento científico. Pesquisa Fapesp Online, São Paulo, n. 95, jan. 2004. Disponível em: $<\mathrm{http}: / /$ revistapesquisa2.fapesp.br/?art=2356\&bd=1\&pg=1\&lg=>. Acesso em: 07 dez. 2012.

JENSEN, Pablo. Chercheurs, citoyens: au café (des sciences)!. Le Monde, Paris, 22 dez. 1998. Éditorial Recherhe et Applications, p. 15. Disponível em:

<http://perso.ens-lyon.fr/pablo.jensen/lemonde>. Acesso em: 05 abr. 2013.

KRESS, G. Reading images: multimodality, representation and new media. In: CONFERENCE PREPARING FOR THE FUTURE OF KNOWLEDGE PRESENTATION, 2004, Chicago. Disponível em: <http://www.knowledgepresenta tion.org/BuildingTheFuture/Kress2/Kress2.html>. Acesso em: 10 set. 2012.

LATOUR, B. A esperança de pandora: ensaios sobre a realidade dos estudos científicos. Bauru, SP: EDUSC, 2001.

Ciência em ação: como seguir cientistas e engenheiros sociedade afora. São Paulo: UNESP, 2000.

LAUER, C. Contending with terms: "multimodal" and "multimídia" in the academic and public spheres. Computers and Composition, New York, v. 26, p. 225-239, 2009. Disponível em: <http://dmp.osu.edu/dmac/supmaterials/lauer.pdf>. Acesso em: 10 set. 2012.

LE MAREC, J. Débats, diversité et développement durable: le café scientifique junior dans l'enseignement DD dans diversescultures - Cluster "Enjeux et representations de la science, de la technologie et de leurs usages". Lyon: Université Lyon 2, 2009. (Projeto de pesquisa do grupo Interactions, Corpus, Apprentissages, Représentations - ICAR). 
LEITE, C., PACHECO, N. Os dispositivos pedagógicos na educação inter/multicultural. InterMeio, Campo Grande, v. 14, n. 27, p. 102-111, jan./jun. 2008. Disponível em: <http://www.fpce.up.pt/ciie/publs/actas/CL_NP_SPCE2.pdf>. Acesso em: 11 maio 2011.

LEMOS, A. Ciber-cultura-remix. Trabalho apresentado no Seminário "Sentidos e Processos", dentro da mostra "Cinético Digital" no Centro Itaú Cultural, agosto de 2005, São Paulo. Disponível em: <http://pt.scribd.com/doc/48332999/Andre-LemosCibercultura-Remix>. Acesso em: 29 dez. 2012.

LÉVY, P. The semantic sphere. Translated Phyllis Aronoff and Howard Scott. New York: Wiley, 2011. v. 1: Computation, cognition and the information economy. Disponível em: <http://www.ieml.org/text/TOME1/The\%20Semantic\%20Sphere\%20 Vol1.pdf>. Acesso em: 23 mar. 2012.

LEWENSTEIN, B. V. Models of public communication of science and technology. Public Understanding of Science, New York, v. 16, p. 1-11, jun. 2003.

MACIEL, G. L. S. et al. Ciêncie e dengue: questões produzidas na interação com a esfera semântica. In: ENCONTRO NACIONAL DE PESQUISA EM EDUCAÇÃO EM CIÊNCIAS, VIII, 2011, Campinas. Anais ... Campinas, 2011.

MARTIN G. A., DALY J., THURSTON C. Interaction within multimodal environements in a collaborative setting. Orlando, 2005. Disponível em: <http://www.cs.ucf.edu/ $\sim$ dcm/Teaching/COT4810-Spring2011/Presentations/InteractionsWithinMultiModal Environments.pdf>. Acesso em: 10 set. 2012.

. Interaction within multimodal environments in a collaborative setting.

2005. Disponível em: <http://www.cs.ucf.edu / dcm/Teaching/COT4810-

Spring2011/Presentations/InteractionsWithinMultiModalE nvironments.pdf>. Acesso em: 11 set. 2012.

MODO. In: DICIONÁRIO on line de português. 2012. Disponível em: <http://www.dicio.com.br/modo/>. Acesso em: 10 set. 2012.

MONTEIRO, M. G. M. F. O cientista, a imprensa e a comunicação pública da ciência. UNIrevista, São Leopoldo, v. 1, n. 3, jul. 2006. Disponível em: <http://www.unirevista. unisinos.br/_pdf/UNIrev_FMonteiro.PDF>. Acesso em: 19 abr. 2011.

MORENO, R.; MAYER, R. Interactive multimodal learning environments.

Educational Psychology Review, New York, v. 19, p. 309-326, 2007. Disponível em: <http://link. springer.com/article/10.1007\%2Fs10648-007-9047-2?LI=true\#page1>. Acesso em: 08 jun. 2012.

NASCIMENTO, S. S. L'animation scientifique: essai d'objectivation de la pratique des associations de culture scientifique et technique françaises. 1999. Thése de Doctorat de L'Université Pierre et Marie Curie (Paris 6), Paris.

; VENTURA, P. C. S. Mutações na construção dos museus de ciências. Pro- 
posições, Campinas, v. 12, n. 1, p. 126-137, mar. 2001.

NOHARA, K. et al. Overseas internships as vehicle for developing a meta-level awareness regarding science communication. Journal of Science Communication, [s.l.], v. 7, n. 1, p. 1-12, Mar. 2008. Disponível em: <http://jcom.sissa.it/archive/08/04/ 0804\%282009\%29A01/Jcom0804\%282009\%29A01.pdf> Acesso em: 09 ago 2010.

OLIVEIRA, B. J. Imaginário científico e a história da educação. In: FONSECA, Cynthia; VEIGA, Thaís (Ed.). História e historiografia da educação no Brasil. Belo Horizonte: Autêntica, 2003. p. 101-128.

OLIVEIRA, S. L. Tratado de metodologia científica: projetos de pesquisas, TGI, TCC, monografias, dissertações e teses. São Paulo: Pioneira Thomson Learning, 2002.

OLVERA, C. C. J.; CHÁVEZ, V. C. Una alternativa para divulgar la ciência: el café cientifico. In: REUNIÓN DE LA RED DE POPULARIZACIÓN DE LA CIENCIA Y LA TECNOLOGIA EM AMÉRICA LATINA Y EL CARIBE, X. San José, Costa Rica, 9 al 11 mayo $2007.7 \mathrm{p}$.

POLINO, C. Percepção pública da ciência e desenvolvimento científico local.

ComCiencia, Campinas, 18 jul. 2003. Disponível em: <http://www.comciencia.br/ reportagens/cultura/cultura19.shtml>. Acesso em: 07 dez. 2012.

RAMIREZ, Fernanda. Um chopes, dois pastel e ciência por favor! Polegar Opositor, abr. 2009. Disponível em: <http://polegaropositor.com.br/?s=chopp+cient\%C3\% ADfico>. Acesso em: 07 ago. 2010.

REMBRANDT. A Lição de Anatomia do Dr. Tulp. In: Infopédia. Porto: Porto Editora, 2012. Disponível em: <http://estoriasdahistoria12.blogspot.com.br/2012/04/rembra ndt-e-licao-de-anatomia-do-dr.html>. Acesso em: 20 ago. 2012.

RIESSMAN, C. K. Thematic analysis. In: RIESSMAN, C. K. Narrative methods for the human sciences. New York: Sage Publications, 2007. p. 53-76. Disponível em: <http://books.google.com.br/books?id=0DdzM-vh54UC\&printsec=frontcover\&dq=nar rative+methods+for+the+human+sciences\&hl=pt-BR\&sa=X\&ei=SEodUYGzA8jy0wH wmIDQDg\&ved=0CDIQ6AewAA>. Acesso em: 25 abr 2012

ROCHA, D.; DEUSDARÁ, B. Análise de conteúdo e análise do discurso: aproximações e afastamentos na (re)construção de uma trajetória. ALEA, Rio de Janeiro, v. 7, n. 2, p. 305-322, jul./dez. 2005. Disponível em: <http://www.scielo.br/ pdf/alea/v7n2/a10v7n2.pdf> Acesso em: 15 mar. 2012.

SAUTET, M. Um café para Sócrates: como a filosofia pode ajudar a compreender o mundo de hoje. 7. ed. Tradução Vera Ribeiro. Rio de Janeiro: José Olympio, 2006.

SCIENCE in the pub, um Café Científico australiano. Sidney, 1998. Disponível em: <http://www.scienceinthepub.com/>. Acesso em: 06 ago. 2010.

SCIENCE pub Portland, Oregon Museum of Science and Industry, Portland, 2010. 
Disponível em: <http://www.osmi.edu/sciencepub>. Acesso em: 06 ago. 2010.

SCOLES, S. What do scientists think of Science outreach? [s.I.], 14 May 2012. Disponível em: <http://smallerquestions.squarespace.com/blog/2012/5/14/what-doscientists-think-of-science-outreach.html>. Acesso em: 29 jan. 2013.

SMITH, P. L.; RAGAN, T. J. Instruction design. $2^{\text {nd }}$ ed. New York: Wiley, 1999. Disponível em: <http://books.google.com.br/books?id=Zm1PAAAAMAAJ\&q=introduct ion+to+instructional+design+smith+ragan \&dq=introduction+to+instructional+design+ smith+ragan\&hl=pt-BR\&sa=X\&ei=iUwdUY_gJNDO0QHTi4DoDw\&ved=0CDIQ6AEw AA>. Acesso em: 19 abr. 2012.

SWELLER, J.; VAN MERRIENBOER, J. J. G.; PAAS, F. G. W. C. Cognitive architectute and instructional design. Educational Psychology Review, New York, v. 10, n. 3, p. 251-296, 1998. Disponível em:

<http://link.springer.com/article/10.1023\% 2FA\%3A1022193728205?LI=true\#page-1> Acesso em: 08 jun. 2012.

TAVANO, P. T.; OLIVEIRA, M. C. Surgimento e desenvolvimento da ciência anatômica. Anuário da Produção Acadêmica Docente, São Paulo, v. 2, n. 3, p. 7384, 2008. Disponível em: <http://sare.unianhanguera.edu.br/index.php/anudo/article/ view/683/526>. Acesso em: 17 ago. 2010.

UNIVERSIDADE FEDERAL DA BAHIA. Informações sobre o Café Científico. Blog Café Científico, Salvador, 2010. Disponível em: <http://cafecientificossa.blogspot. com/>. Acesso em: 06 ago. 2010.

UNIVERSIDADE FEDERAL DO RIO GRANDE DO SUL. Informações sobre o Café Científico. Site Café Científico, Porto Alegre, 2010. Disponível em: <http://www.if. ufrgs.br/cafe-sci/Cafe.html>. Acesso em: 06 ago. 2010.

VENTURA, P. C. S. Memória e história de técnicas e tecnologias contadas nos espaços museográficos do CEFET-MG, em cafés de ciência e tecnologia. Belo Horizonte, 2008. (Projeto de pesquisa financiado pela FAPEMIG).

VOCABULÁRIO ORTOGRÁFICO DA LÍNGUA PORTUGUESA. Volp. 5. ed. 2009. Rio de Janeiro: Letras, Academia Brasileira. Global. Disponível em: <http://www.academia.org.br/abl/cgi/cgilua.exe/sys/start.htm?sid=23> acesso em: 19 mai. 2013.

ZAMBONI, L. M. S. Cientistas, jornalistas e a divulgação científica: subjetividade e heterogeneidade no discurso da divulgação científica. Campinas, SP: Autores Associados, 2001. 


\section{APÊNDICES}




\section{APÊNDICE A - Relação dos dados coletados no Café 2 - Projeto "Barômetro" \\ - Ciência, café e debate}

RELAÇÃO DOS DADOS — PROJETO BARÔMETRO/ CAFÉ 2:

\section{1- FICHA TÉCNICA:}

Tema: Ciência e dengue: Vamos combater a dengue?

Data: 14/ abril/ 2011

Quadro 1 - Ocupação profissional e escolaridade dos debatedores

\begin{tabular}{|c|c|}
\hline Debatedor 1 & Debatedor 2 \\
\hline $\begin{array}{l}\text { - médico; } \\
\text { - professor universitário; } \\
\text { - doutor; } \\
\text { - coordenador de instituição nacional de } \\
\text { ciência e tecnologia na área temática } \\
\text { debatida } \\
\end{array}$ & $\begin{array}{l}\text { - dona de casa aposentada; } \\
\text { - ensino médio; } \\
\text { moradora do bairro Jaraguá; } \\
\text { - teve casos de dengue na família }\end{array}$ \\
\hline $\begin{array}{l}\text { Debatedor } 3 \text { (debatedor suporte) } \\
\text { - diarista; } \\
\text { - ensino fundamental incompleto; } \\
\text { - moradora do bairro Icaivera/ } \\
\text { - tentagem; } \\
\text { - teve vários casos de denque na família }\end{array}$ & \\
\hline
\end{tabular}

Quadro 2 - Características (Número, profissão e faixa etária) do público participante

\begin{tabular}{|c|c|c|}
\hline Número de participantes & $\begin{array}{c}\text { Profissão dos } \\
\text { participantes }\end{array}$ & Faixa etária \\
\hline 10 & Professor & 26 a 58 \\
\hline 11 & Estudante & 12 a $70^{*}$ \\
\hline 1 & Designer & 31 \\
\hline 1 & Representante comercial & 41 \\
\hline 1 & $\begin{array}{c}\text { Funcionária pública/ } \\
\text { secretaria de educação }\end{array}$ & 46 \\
\hline 1 & Engenheira & 40 \\
\hline 2 & Empresário & 42 \\
\hline 1 & Artista visual & 43 \\
\hline 1 & Químico & 58 \\
\hline 2 & Pedagoga & $41-42$ \\
\hline 1 & Diarista & 37 \\
\hline 2 & Advogada & $22-23$ \\
\hline 37 & Comunicação & \\
\hline
\end{tabular}

${ }^{*}$ Grupo de EJA 


\section{2- CAMPO SEMÂNTICO PROPOSTO:}

CIÊNCIA: inovação, tecnologia, pesquisa, progresso, especialistas, cientistas, desenvolvimento, avanço, futuro, desconhecido, descoberta, domínio, laboratório, universidade, academia, estudo, método, conhecimento, informação, racional, empírico, verdade, natureza, realidade, cura, prática, saber, sabedoria, filosofia, experiência, cobaia, vida, hipótese, tese, inteligência, artificial, simulação, simulador, cérebro, ética, cientificamente testado, cientificamente aprovado, ficção científica.

DENGUE: SUS, dengue, casos, hemorrágica, óbitos, doença, epidemia, início, cama, molho, mito, caseiro, sorotipos, sudeste, sul, Brasil, década, enfermidade, febre, homem, infecção, milhões, pacientes, países, período, primatas, sorotipo, vírus, amarela, arbovírus, repelente, crianças, dengue-1, dengue-2, dengue-3, dengue-4, distribuição, endemia, gênero, humanos, imunidade, mortalidade, posto de saúde, ocasião, pessoas, população, relatado, rico, pobre, saúde, sintomas, temporária, tipos, tropical, vertebrado,

\section{3- DADOS OBTIDOS ATRAVÉS DA ESFERA SEMÂNTICA}

- Número de combinações de palavras x ocorrência das palavras: 76.

- O número maior de ocorrências de palavras do campo semântico da dengue (46) em relação ao da ciência (31) demonstrou que não houve o critério palavras da ciência x palavras da dengue nas escolhas do público presente. Nem sempre as combinações de palavras seguiram essa marcação semântica.

- Número de combinações somente do campo semântico da ciência: 24 (31,5\%).

- Número de combinações somente do campo semântico da dengue: 22 (29\%).

- Número de combinações dos dois campos semânticos - ciência x dengue: 26 $(34,5 \%)$. 
Quadro 3 - Ciência, Dengue e quantificação de palavras relacionadas a esses tópicos

\begin{tabular}{|c|c|c|c|}
\hline \multicolumn{2}{|c|}{ Ciência } & \multicolumn{2}{|c|}{ Dengue } \\
\hline PALAVRA 1 (66) & OCORRÊNCIA & PALAVRA 2 (86) & OCORRÊNCIA \\
\hline Academia & 2 & Brasil & 2 \\
\hline Avanço & 1 & Cama & 1 \\
\hline Cérebro & 2 & Caseiro & 1 \\
\hline $\begin{array}{l}\text { Cientificamente } \\
\text { aprovado }\end{array}$ & 1 & Casos & 3 \\
\hline Cientistas & 3 & Crianças & 2 \\
\hline Cura & 3 & Dengue & 5 \\
\hline Descoberta & 2 & dengue-1 & 2 \\
\hline Desconhecido & 1 & dengue-2 & 4 \\
\hline Desenvolvimento & 2 & dengue-3 & 5 \\
\hline Domínio & 2 & dengue-4 & 3 \\
\hline Especialistas & 1 & Distribuição & 1 \\
\hline Estudo & 4 & Doença & 3 \\
\hline ficção científica & 2 & Endemia & 1 \\
\hline Hipótese & 1 & Enfermidade & 2 \\
\hline Informação & 3 & Epidemia & 1 \\
\hline Inovação & 3 & Febre & 2 \\
\hline Inteligência & 1 & Gênero & 1 \\
\hline Laboratório & 1 & Hemorrágica & 3 \\
\hline Método & 2 & Homem & 3 \\
\hline Natureza & 1 & Imunidade & 3 \\
\hline Pesquisa & 2 & Infecção & 1 \\
\hline Progresso & 1 & Milhões & 1 \\
\hline Racional & 2 & Mito & 3 \\
\hline Realidade & 3 & Mortalidade & 1 \\
\hline Sabedoria & 1 & Ocasião & 1 \\
\hline Simulação & 1 & Pacientes & 4 \\
\hline Tecnologia & 2 & Países & 1 \\
\hline Universidade & 4 & Pessoas & 1 \\
\hline Verdade & 6 & Pobre & 2 \\
\hline Vida & 5 & Primatas & 1 \\
\hline Tecnologia & 1 & Relatado & 2 \\
\hline & & Repelente & 2 \\
\hline & & Rico & 1 \\
\hline & & Saúde & 3 \\
\hline & & Sorotipos & 1 \\
\hline & & Sudeste & 1 \\
\hline & & Sul & 1 \\
\hline & & Temporária & 2 \\
\hline & & Tropical & 1 \\
\hline & & Vírus & 1 \\
\hline & & Brasil & 1 \\
\hline & & Casos & 1 \\
\hline & & Hemorrágica & 1 \\
\hline & & Homem & 1 \\
\hline & & Mortalidade & 1 \\
\hline & & SUS & 2 \\
\hline
\end{tabular}


Dos 76 links ou combinações arquivadas e tabuladas. Houve:

- Mais correlação entre palavras do mesmo grupo semântico do que os dos dois grupos de comparação num total de 46 combinações - 60,5\%.

- O público associou as palavras do mesmo campo com mais frequência, principalmente no início do debate entre o cientista e as donas de casa.

- As relações entre os dois campos semânticos representaram 1/3 das combinações estabelecidas.

- As correlações semânticas se apresentam com mais frequência quando há um assunto correlacionado ou indicado.

Mapa do índice de palavras mais utilizadas segue a análise de tagueamento: As palavras com o maior índice de uso foram: Casos, dengue, dengue 2 e dengue 3 . Em relação ao campo semântico da Ciência foram: Estudo, homem, verdade e vida. Oitotagsmenos selecionadas: crianças, especialistas, hemorrágica, laboratório, primatas, SUS, sabedoria e tese. 3 tags ligadas à Dengue e 5 a Ciências.

\section{4- CATEGORIAS:}

- mosquito (2), geografia da doença (3), prevenção (4), contágio (5), estudos e pesquisas (6), tratamento da doença (7), sintomas (8), divulgação (9), tipos (10) sociedade, estado.

5- CATEGORIZAÇÃO DAS PERGUNTAS/ COMENTÁRIOS

TABELAS DE CATEGORIAS:

\begin{tabular}{|l|l|}
\hline \multirow{4}{*}{ Categoria 1} & \multicolumn{1}{|c|}{ Descoberta e funcionamento da Esfera } \\
\cline { 2 - 3 } & Zdgrttp \\
\cline { 2 - 3 } & Adgfr \\
\cline { 2 - 3 } & qeaa'. \\
\cline { 2 - 2 } & Aatu \\
\cline { 2 - 2 } & Aie \\
\cline { 2 - 3 } & Aatu \\
\cline { 2 - 2 } & Aie \\
\hline
\end{tabular}




\begin{tabular}{|l|l|}
\hline \multirow{4}{*}{ Categoria 2} & \multicolumn{1}{c|}{ Mosquito } \\
\cline { 2 - 2 } & Só de dia que ele pica? \\
\cline { 2 - 2 } & O mosquito pode ser mesmo o vilão? \\
\cline { 2 - 2 } & $\begin{array}{l}\text { Seria verdade que o mosquito deposita os ovos na parede dos recipien } \\
\text { mesmo sem água e que depois com a presença de água os ovos ecloc }\end{array}$ \\
\cline { 2 - 2 } & O vírus é inteligente?
\end{tabular}

\begin{tabular}{|l|l|}
\hline \multirow{4}{*}{ Categoria 3} & \multicolumn{1}{c|}{ Geografia da Doença } \\
\cline { 2 - 3 } & Como estão os estudos sobre a dengue no Brasil? \\
\cline { 2 - 3 } & A dengue apresenta um avanço racional? \\
\cline { 2 - 3 } & Há muitos casos de dengue detectados no Campus da Pampulha? \\
\cline { 2 - 2 } & Quais são os números da dengue na região sudeste e, \\
\cline { 2 - 2 } & especialmente, em Belo Horizonte? \\
\cline { 2 - 2 } & Sudengue bem distribuída? \\
\cline { 2 - 2 } & A dengue só aparece em país tropical? \\
\cline { 2 - 2 } & Onde? \\
\cline { 2 - 2 } & Foi relatado algum caso de dengue quatro em MG? \\
\cline { 2 - 2 } & Tem dengue 4 em Minas? \\
\cline { 2 - 2 } & Em que países há a dengue? \\
\hline
\end{tabular}

\begin{tabular}{|l|l|}
\hline \multirow{5}{*}{ Categoria 4} & \multicolumn{1}{c|}{ Prevenção } \\
\cline { 2 - 2 } & $\begin{array}{l}\text { Há muitas campanhas de prevenção que envolvem as crianças. } \\
\text { Como elas realmente podem compreender a dimensão da dengue na } \\
\text { nossa cidade? }\end{array}$ \\
\cline { 2 - 2 } & $\begin{array}{l}\text { Nós podemos ter algumas ações caseiras para prevenir a dengue? } \\
\text { Professor o senhor acredita que um dia venceremos essa guerra? a } \\
\text { dengue já esta na sua versão 4 e nós ainda não conseguimos educar } \\
\text { a população. Nem pra versão 2 }\end{array}$ \\
\cline { 2 - 2 } & $\begin{array}{l}\text { Se as diferenças dos produtos já fracos para matar os ovinhos do } \\
\text { mosquito? Por exemplo o pozinho que eles colocam nos vasos de } \\
\text { plantas? Abigail de Lima }\end{array}$ \\
\hline
\end{tabular}

\begin{tabular}{|l|l|}
\hline \multirow{4}{*}{ Categoria 5} & \multicolumn{1}{c|}{ Prevenção } \\
\cline { 2 - 2 } & $\begin{array}{l}\text { Há muitas campanhas de prevenção que envolvem as crianças. } \\
\text { Como elas realmente podem compreender a dimensão da dengue na } \\
\text { nossa cidade? }\end{array}$ \\
\cline { 2 - 2 } & $\begin{array}{l}\text { Nós podemos ter algumas ações caseiras para prevenir a dengue? } \\
\text { Professor o senhor acredita que um dia venceremos essa guerra? A } \\
\text { dengue já está na sua versão 4 e nós ainda não conseguimos educar } \\
\text { a população. Nem pra versão 2 }\end{array}$ \\
\cline { 2 - 2 } & $\begin{array}{l}\text { Se as diferenças dos produtos já fracos para matar os ovinhos do } \\
\text { mosquito? Por exemplo o pozinho que eles colocam nos vasos de } \\
\text { plantas? Abigail de Lima }\end{array}$ \\
\hline
\end{tabular}




\section{6- REGISTROS DO CADERNO DE OPINIÕES:}

"[...] Um momento para encontrar amigos, colegas e participar de discussões em que o conhecimento científico realmente dialoga com os saberes populares".

"O projeto favorece a discussão de vários pontos de vista, sem desqualificar os diferentes tipos de conhecimentos, além de propiciar a participação de maneira interativa".

"O projeto é oportuno, provando que a ciência é simples, necessária, e que deve ser 'transportada' dos laboratórios de pesquisa, para as praças e ruas numa linguagem popular [...]".

"Bem, acho que o evento traz uma proposta real e de dinâmica gostosa [...]". 


\section{APÊNDICE B - Perguntas selecionadas pela Equipe da Rádio}

Do universo de perguntas elaboradas em cada evento, apenas uma parte delas veio a público por meio dos apresentadores da rádio. Essas perguntas foram selecionadas pelos estudantes/interlocutores e seus ajudantes sem qualquer interferência da equipe de concepção do "Barômetro". Foi através dessas perguntas que o debate se desenrolou. Uma abordagem local, no fervor do programa no ar, foi realizada em uma tentativa momentânea para entender o modo de agir da equipe de mediadores.

\section{Critério de escolha das perguntas/comentários - abordagem local:}

Segundo a repórter tablet, seu critério de escolha das perguntas e comentários elaborados pelo público participante através da esfera semântica e do uso dos tablets foi - "As perguntas inteligentes".

O programa contou, principalmente, com dois tipos de perguntas - as que vieram dos tablets e foram projetadas e visualizadas por todos os presentes e as que foram feitas pelo microfone, cara a cara com o debatedor. É bom lembrar que muitas vezes a pergunta feita ao vivo pelo microfone é a pergunta que o participante enviou pela tablet e por algum motivo não foi selecionada. Perguntas e comentários enviados pelo Twitter não foram selecionados pelos assistentes da Repórter Tablet e, portanto, não vieram a público.

Abaixo a relação das perguntas e comentários selecionados e transmitidos ao vivo dos tablets e perguntas feitas pelo público participante:

\section{Barômetro Ciência e Dengue - 2을 evento}

Siglas:

RA: repórter apresentadora

RT: repórter tablet

Médico: debatedor comunidade científica - segundo evento

Dona de casa: debatedor sociedade civil - segundo evento

Diarista: debatedor sociedade civil - segundo evento

PP: público participante - segundo evento

Atribuições e nomes:

Médico - Márcio 
Dona de casa - Luciana

Diarista - Evelyn

Neto da Dona de casa - Guilherme

\section{Relação das perguntas/ comentários TABLET e PÚBLICO}

1- RA/Médico - Professor, quais são as armas, e as armas da Ciência, contra a dengue, agora que a dengue é uma guerra?

2- RA/Médico - E a dengue é um problema em todo o mundo, não é, professor, não só no Brasil

3- RA/Dona de casa - A senhora teve uma neta, duas cunhadas, um filho, e uma nora que contraíram dengue e o caso mais sério, que foi do neto da senhora, o Guilherme, não é?

4- RA/Médico - Como é isso, professor, é diretamente ligada a essa área de estudos... (pergunta originada da Dona de casa - / então/ eu perguntaria/ é de acordo com a imunidade da pessoa, ou não?)

5- RA/Dona de casa - Luciana, como a senhora acha que a gente pode combater a dengue, depois de tantos casos na sua família, a senhora entrou em uma guerra contra a dengue também?

6- RA/Dona de casa - e a senhora tem uma receita de repelente natural, não é, Luciana?

7- RA passa a palavra ao Médico - Bom, porque o repelente não tem um cheiro muito bom não. O professor quer falar...

8- RA/Diarista - É bom ficar esperto. Nós temos aqui também a Evelyn, que trabalha como diarista e mora em Contagem, no bairro Icaivera, e a senhora, o seu filho e o seu irmão já tiveram dengue. Como é a dengue lá no seu bairro?

9- Diarista/Médico - então/ o menino morreu/ por que não fizeram o exame antes/ por que não tentaram descobrir antes?/ [Porque] depois de sete dias é que tem de fazer o exame?

10-Diarista/Médico - mas eu queria saber/ assim/ e se não for dengue?/ não há um jeito mais fácil de a pessoa descobrir/ em 24 horas/ se está com dengue ou não?

11-Diarista/Médico - me desculpe/ senhor não respondeu a minha pergunta/ mas demora muito/ e muitas das vezes/ a pessoa está com uma doença grave/ e é tratado como se estivesse com dengue/ e não está com dengue/ porque demora tantos dias para tudo. 
12-Músico/Médico - o Márcio meio que respondeu sim/ geralmente/ a gente tem muito daquela coisa de se automedicar/ geralmente/ sete dias para quem tem os sintomas/ é uma coisa que demora muito/ geralmente/ as pessoas costumam tomar alguns remédios/ e no caso da dengue/ a gente sabe que tem algumas contra indicações de alguns remédios/ eles dizem que a Aspirina é algo que vai contra a cura/ e já que temos de esperar estes sete dias/ o que devemos fazer...Qual o tratamento que devemos fazer durante estes sete dias?

13-RT/Médico - a dengue sempre aproveita a ocasião?

14-RT se dirige para Diarista - E a senhora estava falando que perto de sua casa ela estava aproveitando a ocasião!

15-RT/Diarista - a Dengue pode ser medicada com cuidados em casa? Certamente, é uma maneira de contribuir para a erradicação da dengue, são os cuidados em casa. Eu queria saber então da Evelyn, quais são os cuidados na sua casa?

16-RT/Dona de casa - Luciana, quais são os cuidados que a senhora toma dentro de casa?

17-RT/Médico - professor, e o que você faz para combater a dengue?

18-Diarista/Médico - professor/ o que o senhor acha do fumacê? [O professor the pede para repetir, mas a repetição foi emudecida]

19-RT/Médico - além do fumacê, existe algum mito relacionado à dengue? Ou qual o maior, mais perigoso relacionado à dengue?

20-RT/PP1 - me parece que a senhora tomou um chá milagroso contra a dengue, é isto mesmo?

21-RT/Médico - Bom, e este caso, é um mito?

22-PP1 replica a resposta do Médico - se eu não tivesse tomado o chá/ eu [mudo], mas acontece que eu fui persistente/ e eu tinha certeza de que iria sarar

23-RA/Médico - Professor, um outro mito, eu estava conversando antes com a Luciana e ela falou uma história de comer inhame

24-PP3/Médico - foi falado a respeito da participação das crianças no combate à dengue/ eu/ como professora/ percebo que muitas vezes esses trabalhos de prevenção acabam criando nas crianças um sentimento de pouca dimensão da gravidade dessa questão de saúde/ é realmente um problema social/ como vocês veem isto?

25-RT/PP4 - Você tem medo de dengue?

26-RT/PP4 - E você usa o repelente que a sua avó aprendeu no (programa de 
televisão)?

27-RT/PP4 - Você usa algum outro repelente, não usa?

28-RT/PP4 - Mas é um que já compra na farmácia?

29-RT/PP4 - e o que vocês aprendem sobre dengue na escola? Tem campanha?

30-RT/PP4 - Aprendem sobre transmissão, sobre essas coisas assim?

31-RT/PP4 - Pergunta inaudível

32-Dona de casa/Médico - Professor, o senhor acha que quantos dias que uma água, por exemplo, de um balde que a pessoa deixa [mudo]

33-RT/Dona de casa - dengue e pobreza podem ser associados?

34-PP5/Diarista - a senhora já modificou a sua atitude em relação à dengue em função da intervenção da escola?

35-NÃO IDENTIFICADO - Independentemente do combate à larva ou ao mosquito?/ e que prazo de tempo tem isso?

36-RT/Médico - Professor, o senhor disse que aparecem perguntas fáceis de resolver, esta é uma dúvida minha e dúvida de quem está aqui também: quando aparece dengue-I, dengue-II, dengue-III, dengue-IV... o que é isto? Qual é a diferença entre estes tipos... Podemos falar em tipos de dengue?

37-Dona de casa/Médico - Professor, o senhor disse que é estudo, e tão cedo não vai haver nada para apresentar. No estudo que vocês fazem, o que acha será a primeira coisa que vai chegar para a população?

38-Dona de casa/Médico - é verdade que o primeiro caso de dengue aconteceu em Recife/ em 1685/ que veio navios negreiros/ que continham latões de água?

39-PP6/Médico - eu posso ter sido infectada, não no meu bairro... Qual é o perigo, enquanto estou doente, das pessoas da minha casa serem infectados, não pelo próprio mosquito, mas por outro tipo de mosquito? Existe disso, é uma coisa que me preocupa

40-RT/Médico - É verdade que o combate à dengue virou profissão? Será? 41-RT/Médico - Como é que são os estudos no Brasil em relação à dengue? 


\section{APÊNDICE C - CAFÉ —Diário de Bordo}

Observações/ Anotações

Debatedores - Representantes da ciência

- Dependência do uso do Power point;

- Dependência da necessidade de preparar algum tipo de material para o debate;

- Dependência da necessidade de se prepararem com antecedência;

- Entendem a proposta e a dinâmica do programa apenas quando estão no local, por mais que isso tenha sido explicado antes;

- Alguns relataram dificuldade de lidar com o público, de falar para o público.

Debatedores - Representantes da sociedade civil

- Apresentam-se numa posição de inferioridade (conceitual, intelectual) em relação ao representante da ciência, com certo medo de falar;

- A diferença de escolarização foi um dos motivos que contribuíram para essa situação;

- No debate ciência e arte, o debatedor da sociedade civil apresentou um Power point de seus trabalhos recentes (para ele seria difícil falar de arte sem a presença de material visual).

Equipe de repórteres da rádio

- Demonstraram pouca familiaridade com os temas propostos - exerceram o papel de mediadores;

- Prepararam material sobre o assunto, estudaram, elaboraram suas próprias questões para iniciarem o diálogo e o debate com os debatedores;

- Relataram dificuldade em lidar com as questões propostas nos convites (ciência e arte principalmente);

- Estabeleceram critérios para escolher as perguntas que foram passadas aos debatedores, se preocuparam em manter e aquecer o debate.

Público participante

- Ao mesmo tempo em que foi estimulado pelos campos semânticos e a interação com a esfera, se sentiu protegido pela condição de permanecerem anônimos em relação às questões enviadas;

- Acompanharam com atenção a projeção das perguntas na esfera; 
- Poucos se candidataram a perguntar ao microfone.

O debate

- O debate fica mais interessante quando a diferença de escolarização entre os debatedores é maior - comunidade científica (doutores) x sociedade civil (ensino médio, ensino fundamental);

- Níveis de escolaridade semelhantes entre os debatedores geraram certo equilíbrio na situação de debate;

- O debate, a situação criada, foi um momento de expectativa e surpresa tanto para os representantes da comunidade científica quanto para os representantes da sociedade civil.

\section{A imprensa}

- A imprensa fez a divulgação através da reprodução das informações que estão presentes no material de divulgação;

- A imprensa não se preocupou em entender a dinâmica do programa;

- Para a imprensa bastou entrevistar com os debatedores (sem participar do evento o que eles têm a dizer?).

Questões:

1- A esfera de produção do conhecimento científico engessa a capacidade de comunicação de seus sujeitos para fora dela?

2- É mais fácil se comunicar entre seus pares? É mais cômodo? É mais fácil se comunicar com quem "fala a mesma língua"?

3- O processo de comunicação do conhecimento científico está inserido nos aparatos acadêmicos (a dependência de se prepararem, de estarem amparados pelos recursos tecnológicos, de estarem inseridos em ambientes com características acadêmicas)?

4- Por que os representantes da sociedade civil, embora se sintam pouco à vontade, não dependem desses aparatos?

5- Por que é mais fácil para eles lidarem com o inesperado, com o não programado?

6- Em relação ao público, se não houvesse o recurso da esfera, a elaboração das 
perguntas teria a mesma intensidade/ quantidade?

7- Como a mediação da equipe da rádio contribui para essa relação entre público e debatedores?

8- Ela é necessária? Ou, se não houvesse a mediação esse diálogo seria possível? Em qual situação?

9- É necessária a criação de situações comunicacionais como os eventos dos Cafés Científicos para que os representantes das diversas esferas do conhecimento e da sociedade civil possam se encontrar?

10-Qual a importância do contexto? Do ambiente?

11-O que transita em torno do processo de comunicação pública da ciência? Podemos chegar a conclusões que demonstrem uma tendência geral em relação a esse processo? 


\section{APÊNDICE D - Estudo de Público}

Quadro geral do público que compareceu ao Centro Cultural:

\begin{tabular}{|c|c|}
\hline Café & Número de Participantes \\
\hline 1 & 30 \\
\hline 2 & 37 \\
\hline 3 & 31 \\
\hline 4 & 10 \\
\hline 5 & 33 \\
\hline 6 & 61 \\
\hline 7 & 25 \\
\hline 8 & 10 \\
\hline Total & 236 \\
\hline
\end{tabular}

- Público participante - ocorrências expressivas

\begin{tabular}{|c|c|}
\hline Número de participantes & Profissão dos participantes \\
\hline 67 & Professor/a \\
\hline 48 & Estudante \\
\hline $\mathbf{1 1 5}$ & Total \\
\hline
\end{tabular}

Dentre as diversas profissões dos participantes que compareceram ao Centro Cultural, duas tiveram respectivamente ocorrências expressivas, conforme o quadro acima - professores e estudantes. Do número total de participantes (236) as duas profissões juntas corresponderam a praticamente $50 \%$ das ocorrências. Esses números não identificam se correspondem a frequências em apenas um ou mais eventos dos cafés.

O público participante do "Barômetro - Ciência, café e debate" foi composto por duas partes iguais que se dividiram em professores em pleno exercício da profissão e estudantes de graduação e pós-graduação de um lado, e 33 variedades de profissões de outro. A divisão em duas partes fez uso do quesito "profissão" e colocou, de um lado, um grupo de pessoas cujas profissões estão relacionadas ao contexto escolar e, de outro, um grupo de pessoas cujas profissões se encontram entre as mais variadas possíveis. Mas mesmo entre o grupo de profissões variadas, a ligação com o contexto escolar não deixa de aparecer porque uma parte das pessoas cujas profissões estão relacionadas nesse grupo são alunos de um curso de EJA e foram ao Centro Cultural levados e acompanhados por seus professores.

Abaixo segue o quadro das profissões: 
Quadro 1 - Profissões

\begin{tabular}{|c|c|}
\hline Categorização das profissões & Profissões \\
\hline Relacionadas à atividade acadêmica & $\begin{array}{l}\text { Historiador } \\
\text { Geógrafo } \\
\text { Pedagogo } \\
\text { Biólogo } \\
\text { Químico } \\
\text { Pesquisador }\end{array}$ \\
\hline $\begin{array}{l}\text { Relacionadas à atividade artística ou } \\
\text { às artes aplicadas }\end{array}$ & $\begin{array}{l}\text { Ator } \\
\text { Músico } \\
\text { Artista plástico } \\
\text { Artista visual } \\
\text { Designer } \\
\text { Estilista } \\
\text { Fotógrafo }\end{array}$ \\
\hline Relacionadas aos serviços gerais & $\begin{array}{l}\text { Camareira } \\
\text { Jardineiro } \\
\text { Reformador de móveis } \\
\text { Diarista } \\
\text { Doméstica } \\
\text { Motorista } \\
\text { Auxiliar de manutenção } \\
\text { Técnicos }\end{array}$ \\
\hline Relacionadas às atividades corporativas & $\begin{array}{l}\text { Administrador } \\
\text { Engenheiro } \\
\text { Empresário }\end{array}$ \\
\hline Relacionadas às atividades comerciais & Representante comercial \\
\hline $\begin{array}{l}\text { Relacionadas às atividades/ profissões } \\
\text { Liberais }\end{array}$ & $\begin{array}{l}\text { Advogado } \\
\text { Psicólogo }\end{array}$ \\
\hline $\begin{array}{l}\text { Relacionadas às atividades de } \\
\text { Comunicação }\end{array}$ & $\begin{array}{l}\text { Radialista } \\
\text { Jornalista } \\
\text { Comunicação (sem especificação) }\end{array}$ \\
\hline $\begin{array}{l}\text { Relacionadas às atividades da área } \\
\text { Da saúde e de caráter assistencial }\end{array}$ & $\begin{array}{l}\text { Medico veterinário } \\
\text { Assistente social } \\
\text { Tecnólogo de alimentos }\end{array}$ \\
\hline
\end{tabular}

